Prepared in cooperation with the California State Water Resources Control Board A product of the California Groundwater Ambient Monitoring and Assessment (GAMA) Program

\title{
Groundwater-Quality Data in the Western San Joaquin Valley Study Unit, 2010: Results from the California GAMA Program
}
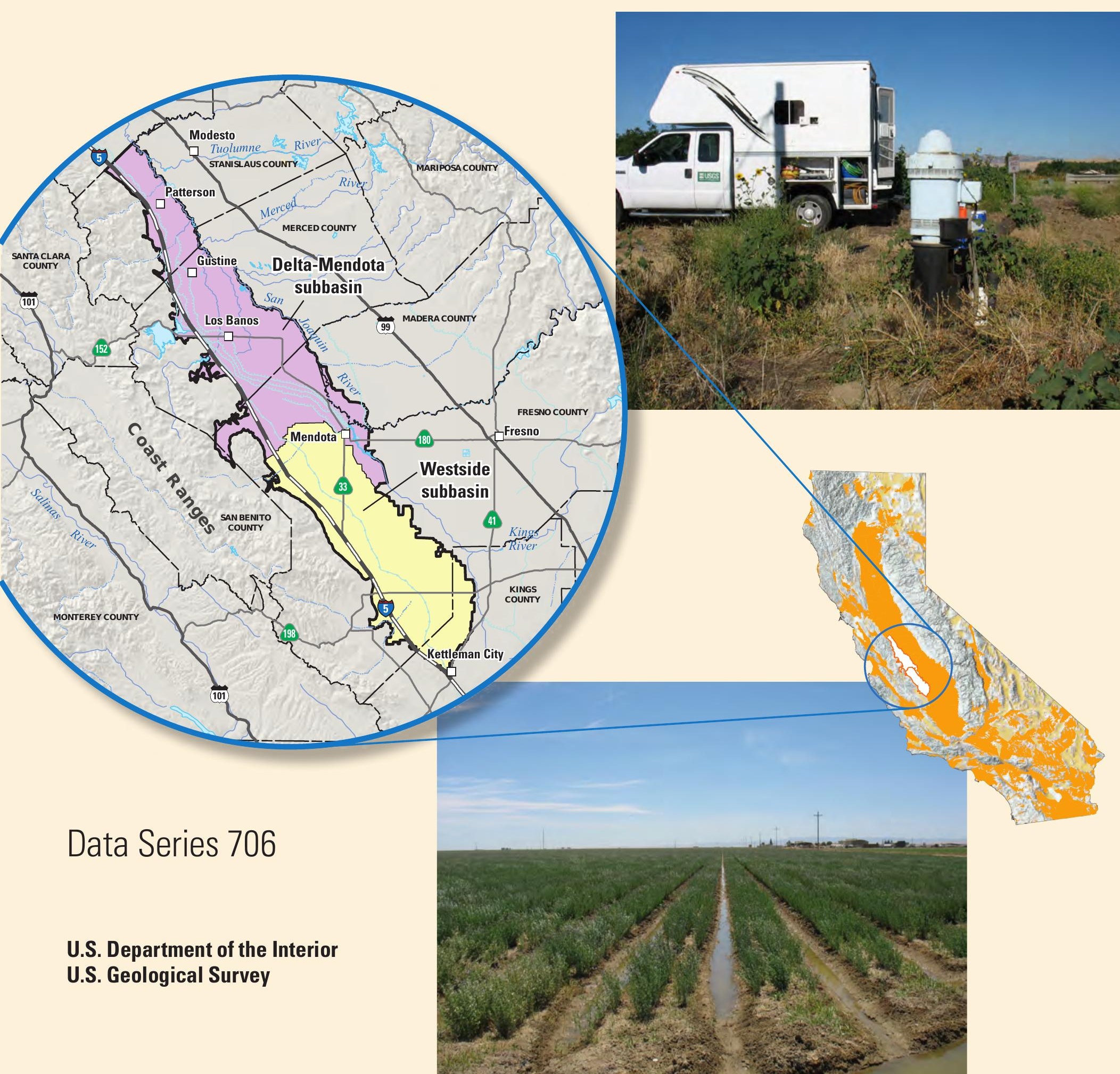

Data Series 706

U.S. Department of the Interior U.S. Geological Survey 


\section{Cover photographs:}

Top right: Irrigation well, Gustine, California. (Photograph taken by Gregory Brewster, U.S. Geological Survey).

Bottom right: Alfalfa field, Five Points, California. (Photograph taken by Tyler Johnson, U.S. Geological Survey). 


\section{Groundwater-Quality Data in the Western San Joaquin Valley Study Unit, 2010: Results from the California GAMA Program}

By Timothy M. Mathany, Matthew K. Landon, Jennifer L. Shelton, and Kenneth Belitz

A product of the California Groundwater Ambient Monitoring and Assessment (GAMA) Program

Prepared in cooperation with the California State Water Resources Control Board

Data Series 706 


\section{U.S. Department of the Interior \\ KEN SALAZAR, Secretary \\ U.S. Geological Survey \\ Marcia K. McNutt, Director}

U.S. Geological Survey, Reston, Virginia: 2013

For more information on the USGS - the Federal source for science about the Earth, its natural and living resources, natural hazards, and the environment, visit http://www.usgs.gov or call 1-888-ASK-USGS.

For an overview of USGS information products, including maps, imagery, and publications, visit http://www.usgs.gov/pubprod

To order this and other USGS information products, visit http://store.usgs.gov

Any use of trade, product, or firm names is for descriptive purposes only and does not imply endorsement by the U.S. Government.

Although this report is in the public domain, permission must be secured from the individual copyright owners to reproduce any copyrighted materials contained within this report.

Suggested citation:

Mathany, T.M., Landon, M.K., Shelton, J.L., and Belitz, Kenneth, 2013, Groundwater-quality data in the Western San Joaquin Valley study unit, 2010—Results from the California GAMA Program: U.S. Geological Survey Data Series 706, $102 \mathrm{p}$. 


\section{Contents}

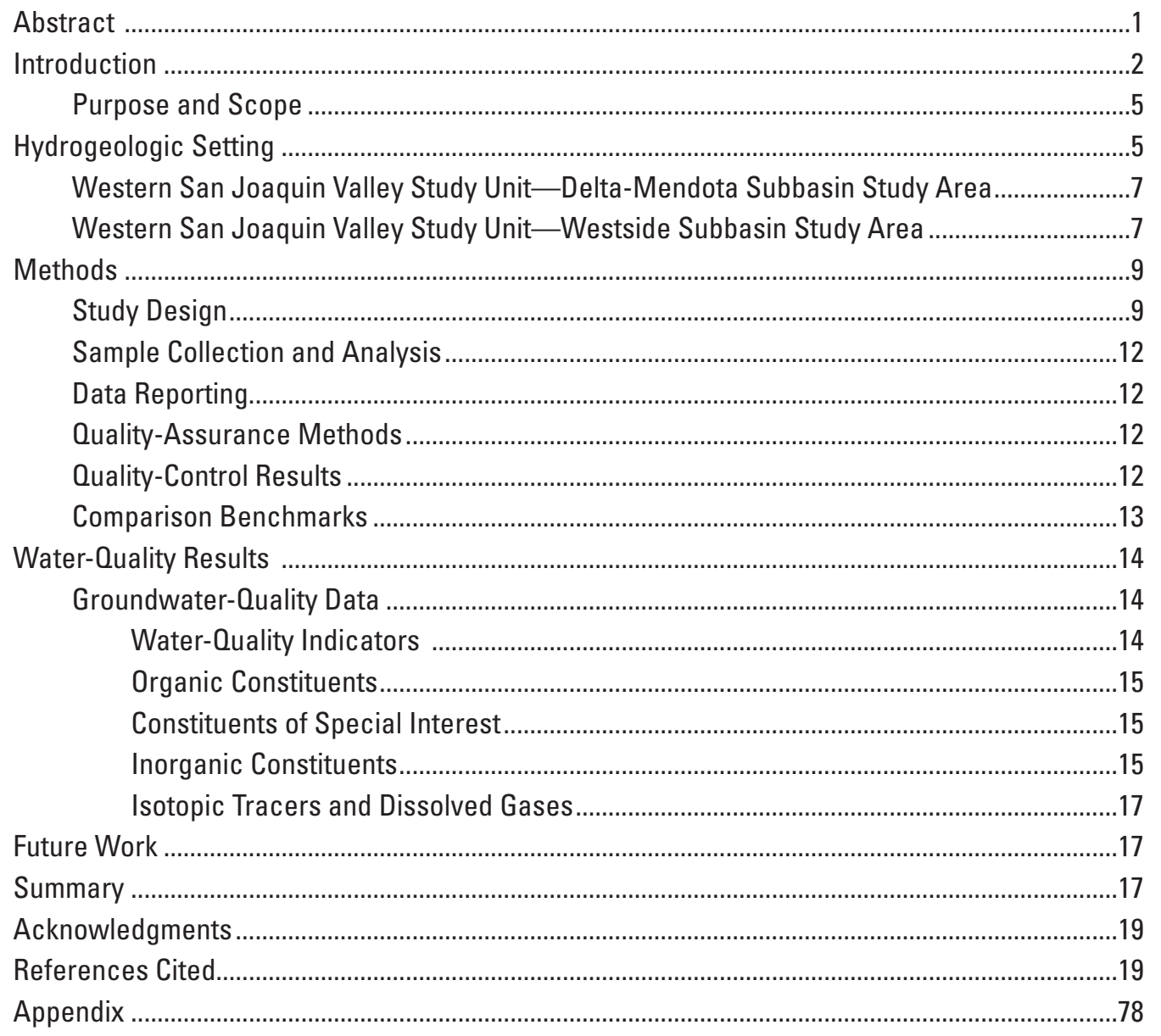




\section{Figures}

Figure 1. Map showing hydrogeologic provinces of California and the location of the Western San Joaquin Valley Groundwater Ambient Monitoring and Assessment study unit

Figure 2. Map showing boundaries of the Delta-Mendota subbasin and the Westside subbasin study areas, geologic formations, major cities, major roads, and hydrologic features

Figure 3. Map showing the Delta-Mendota subbasin and the Westside subbasin study areas, and the boundaries of the California Department of Water Resources defined groundwater subbasins

Figure 4. Map showing the Delta-Mendota subbasin and the Westside subbasin study areas, the distribution of the grid cells, and the location of California Department of Public Health wells

Figure 5. Map showing the Delta-Mendota subbasin and the Westside subbasin study areas, the distribution of the grid cells, and the location of sampled grid and understanding wells

\section{Tables}

Table 1. Identification, sampling, and construction information for wells sampled for the Western San Joaquin Valley Groundwater Ambient Monitoring and Assessment study unit, California, March to July 2010

Table 2. Classes of chemical constituents and water-quality indicators collected for the slow and the intermediate well-sampling schedules in the Western San Joaquin Valley Groundwater Ambient Monitoring and Assessment study unit, California, March to July 2010

Table 3A. Volatile organic compounds, primary uses or sources, comparative benchmarks, and reporting information for the U.S. Geological Survey National Water Quality Laboratory Schedule 2020

Table 3B. Low-level fumigants, primary uses or sources, comparative benchmarks, and reporting information for the U.S. Geological Survey National Water Quality Laboratory Schedule 1306

Table 3C. Pesticides and pesticide degradates, primary uses or sources, comparative benchmarks, and reporting information for the U.S. Geological Survey

National Water Quality Laboratory Schedule 2033

Table 3D. Constituents of special interest, primary uses or sources, comparative benchmarks, and reporting information for Weck Laboratories, Inc., City of Industry, California, analyses

Table 3E. Trace elements, comparative benchmarks, and reporting information for the U.S. Geological Survey National Water Quality Laboratory Schedule 1948

Table 3F. Nutrients and dissolved organic carbon, comparative benchmarks, and reporting information for the U.S. Geological Survey National Water Quality Laboratory Schedule 2755 and Laboratory Code 2613

Table 3G. Major and minor ions, silica, total dissolved solids, and alkalinity, comparative benchmarks, and reporting information for the U.S. Geological Survey National Water Quality Laboratory Schedule 1948 


\section{Tables-Continued}

Table 3H. Total arsenic and iron (unfiltered) and arsenic, chromium, and iron species (filtered), comparative benchmarks, and reporting information for the U.S. Geological Survey National Research Laboratory Trace Metal Laboratory, Boulder, Colorado, analyses

Table 3l. Isotopic tracers, comparison benchmarks, and reporting information for laboratory analyses

Table 4. Water-quality indicators in samples collected for the Western San Joaquin Valley Groundwater Ambient Monitoring and Assessment study unit, California, March to June 2010

Table 5. Volatile organic compounds and low-level fumigants detected in samples collected for the Western San Joaquin Valley Groundwater Ambient Monitoring and Assessment study unit, California, March to June 2010

Table 6. Pesticides and pesticide degradates detected in samples collected for the Western San Joaquin Valley Groundwater Ambient Monitoring and Assessment study unit, California, March to July 2010

Table 7. Constituents of special interest detected in the samples collected for the Western San Joaquin Valley Groundwater Ambient Monitoring and Assessment study unit, California, March to July 2010

Table 8. Trace elements collected for the Western San Joaquin Valley Groundwater Ambient Monitoring and Assessment study unit, California, March to July 2010

Table 9. Nutrients and dissolved organic carbon detected in samples collected for the Western San Joaquin Valley Groundwater Ambient Monitoring and Assessment study unit, California, March to July 2010

Table 10. Major and minor ions, silica, and total dissolved solids detected in samples collected for the Western San Joaquin Valley Groundwater Ambient Monitoring and Assessment study unit, California, March to July 2010

Table 11. Total arsenic and iron (unfiltered) and arsenic, chromium, and iron species (filtered) detected in samples collected for the Western San Joaquin Valley Groundwater Ambient Monitoring and Assessment study unit, California, March to June 2010

Table 12. Isotopic tracers detected in samples collected for the Western San Joaquin Valley Groundwater Ambient Monitoring and Assessment study unit, California, March to June 2010

Table 13. Results for analyses of dissolved standard gases detected in samples collected for the Western San Joaquin Valley Groundwater Ambient Monitoring and Assessment study unit, California, March to July 2010 


\section{Conversion Factors}

\section{Inch/Pound to SI}

\begin{tabular}{|c|c|c|}
\hline Multiply & By & To obtain \\
\hline \multicolumn{3}{|c|}{ Length } \\
\hline inch (in.) & 2.54 & centimeter $(\mathrm{cm})$ \\
\hline inch (in.) & 25.4 & millimeter (mm) \\
\hline foot $(\mathrm{ft})$ & 0.3048 & $\operatorname{meter}(\mathrm{m})$ \\
\hline mile (mi) & 1.609 & kilometer $(\mathrm{km})$ \\
\hline \multicolumn{3}{|c|}{ Area } \\
\hline square mile $\left(\mathrm{mi}^{2}\right)$ & 2.590 & square kilometer $\left(\mathrm{km}^{2}\right)$ \\
\hline \multicolumn{3}{|c|}{ Volume } \\
\hline quart (qt) & 0.9464 & liter $(\mathrm{L})$ \\
\hline \multicolumn{3}{|c|}{ Mass } \\
\hline pound, avoirdupois (lb) & 0.4536 & kilogram (kg) \\
\hline
\end{tabular}

\section{SI to Inch/Pound}

\begin{tabular}{lcl}
\hline \multicolumn{1}{c}{ Multiply } & By & \multicolumn{1}{c}{ To obtain } \\
\hline & Length & \\
\hline micrometer $(\mu \mathrm{m})$ & $3.3 \times 10^{-6}$ & foot $(\mathrm{ft})$ \\
centimeter $(\mathrm{cm})$ & 0.3937 & inch (in.) \\
kilometer $(\mathrm{km})$ & 0.6214 & mile (mi) \\
\hline \multicolumn{3}{c}{ Area } \\
\hline square kilometer $\left(\mathrm{km}^{2}\right)$ & 0.3861 & square mile $\left(\mathrm{mi}^{2}\right)$ \\
\hline \multicolumn{3}{l}{ Volume } \\
\hline liter $(\mathrm{L})$ & 1.057 & quart (qt) \\
\hline gram $(\mathrm{g})$ & Mass & ounce, avoirdupois $(\mathrm{oz})$ \\
kilogram $(\mathrm{kg})$ & 0.03527 & pound, avoirdupois $(\mathrm{lb})$ \\
\hline
\end{tabular}

Temperature in degrees Celsius $\left({ }^{\circ} \mathrm{C}\right)$ may be converted to degrees Fahrenheit $\left({ }^{\circ} \mathrm{F}\right)$ as follows:

$$
{ }^{\circ} \mathrm{F}=\left(1.8 \times^{\circ} \mathrm{C}\right)+32 .
$$

Vertical coordinate information is referenced to the North American Vertical Datum of 1988 (NAVD 88).

Horizontal coordinate information is referenced to the North American Datum of 1983 (NAD 83).

Land-surface altitude, as used in this report, refers to distance above the vertical datum and is reported as feet above mean sea level ( $\mathrm{ft}$ above $\mathrm{msl}$ ).

Specific conductance is given in microsiemens per centimeter at 25 degrees Celsius $(\mu \mathrm{S} / \mathrm{cm}$ at $\left.25^{\circ} \mathrm{C}\right)$.

Concentrations of chemical constituents in water are given either in milligrams per liter (mg/L) or micrograms per liter $(\mu \mathrm{g} / \mathrm{L})$.

Milligrams per liter is equivalent to parts per million (ppm), and micrograms per liter is equivalent to parts per billion (ppb).

Activities of radioactive constituents in water (except uranium) are given in picocuries per liter (pCi/L). 


\section{Selected Terms and Symbols}

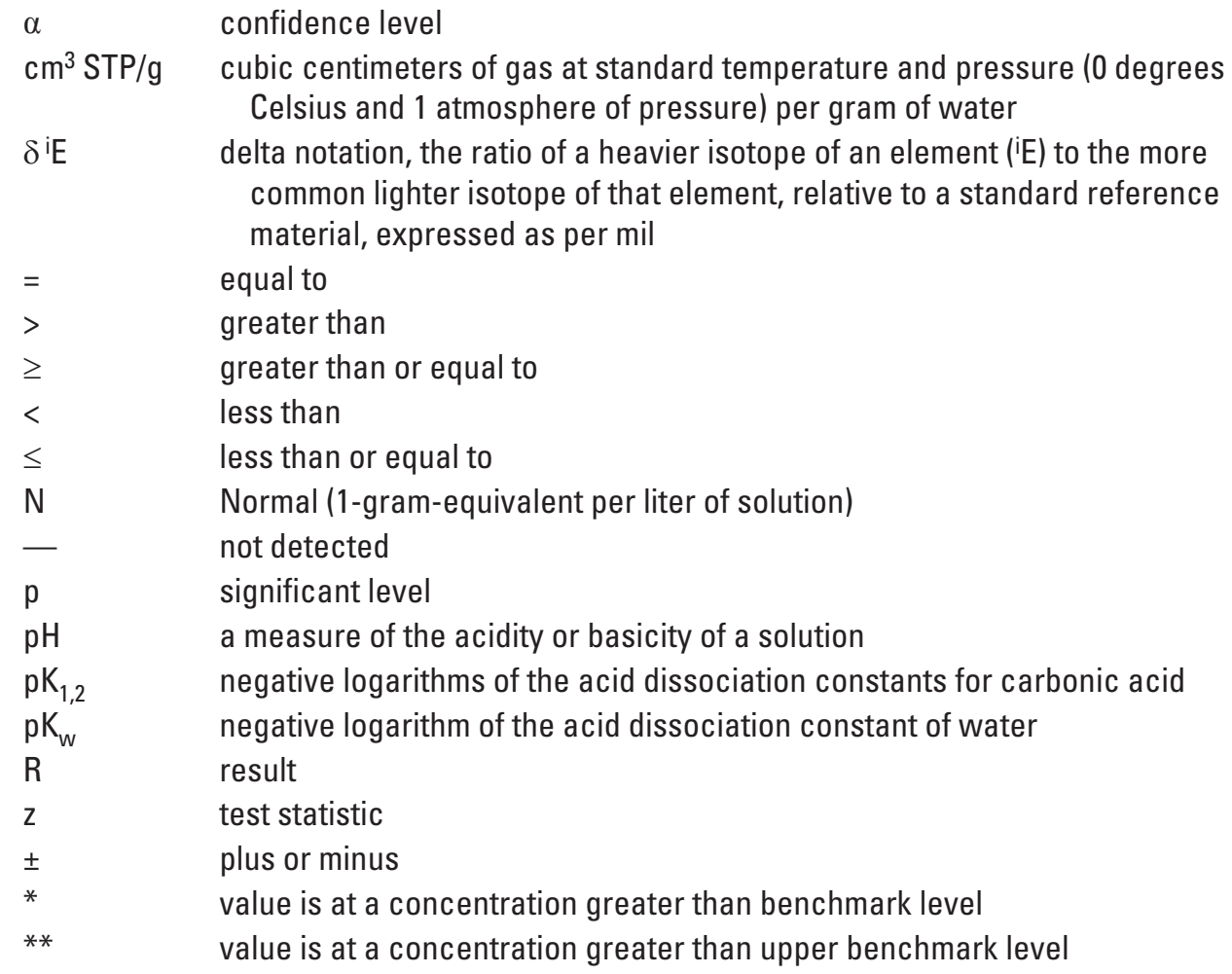

\section{Abbreviations and Acronyms}

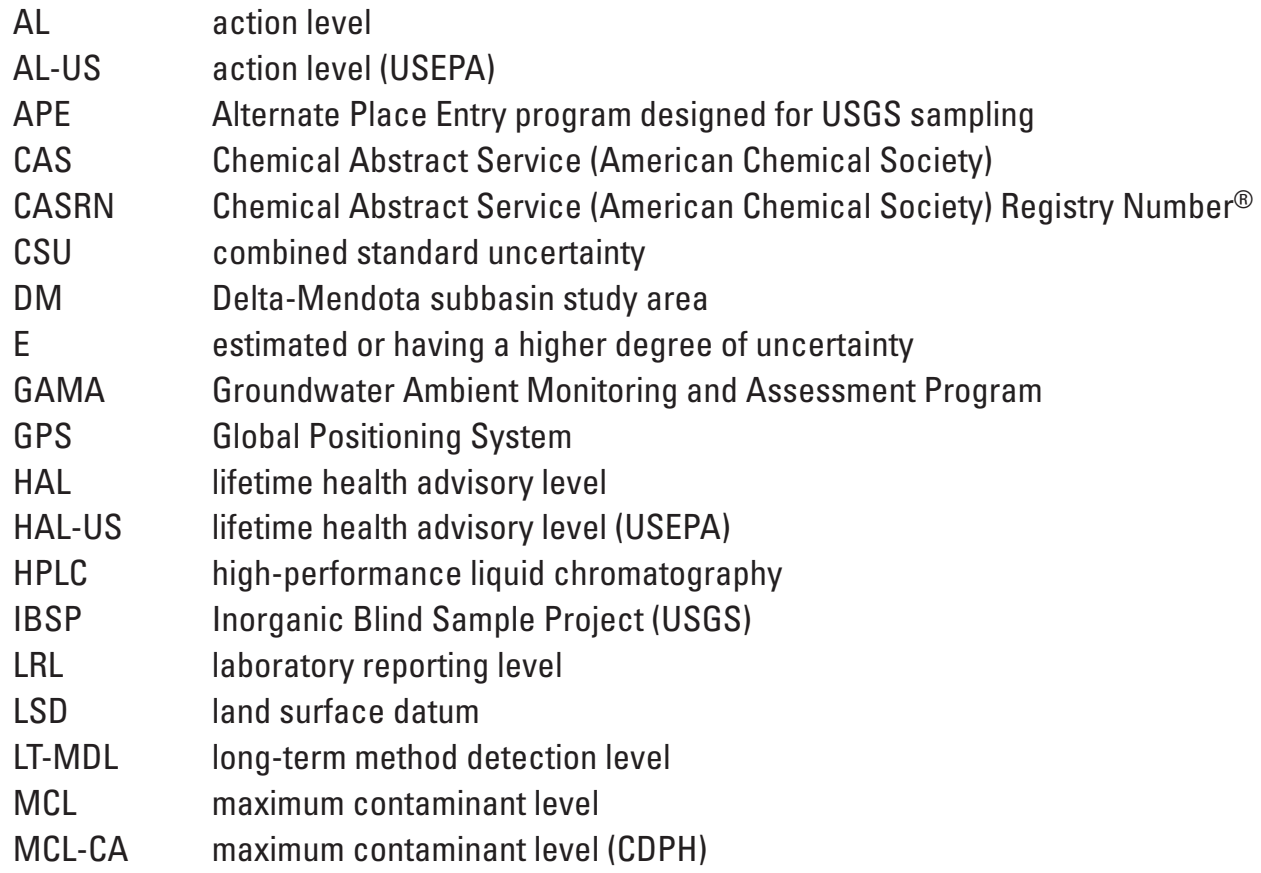




\title{
Abbreviations and Acronyms-Continued
}

\author{
MCL-US maximum contaminant level (USEPA) \\ MDL method detection limit \\ MRL minimum reporting level \\ MU method uncertainty \\ na not available \\ nc not collected \\ NELAP National Environmental Laboratory Accreditation Program \\ NFM National Field Manual (USGS) \\ NFOA National Field Quality Assurance Program (USGS) \\ NL notification level \\ NL-CA notification level (CDPH) \\ np no preference \\ nv no measured value or no value in category \\ NWIS National Water Information System (USGS) \\ PBP Priority Basin Project \\ PCFF Personal Computer Field Form program designed for USGS sampling \\ $\mathrm{OA} \quad$ quality assurance \\ OC quality control \\ $\mathrm{RL} \quad$ reporting level \\ RPD relative percent difference \\ RSD relative standard deviation \\ RSD5-US risk-specific dose at $10^{-5}$ (USEPA) \\ SD standard deviation \\ SMCL secondary maximum contaminant level \\ SMCL-CA secondary maximum contaminant level (CDPH) \\ SMCL-US secondary maximum contaminant level (USEPA) \\ SRL study reporting level (concentration cutoff for applying the $\leq$ symbol) \\ $\mathrm{ssL}_{\mathrm{C}} \quad$ sample-specific critical level \\ U.S. United States \\ UV ultraviolet \\ VCDT Vienna Canon Diablo Troilite (the international reference standard for sulfur \\ isotopes) \\ VPDB Vienna Pee Dee Belemnite (the international reference standard for carbon \\ isotopes) \\ VSMOW Vienna Standard Mean Ocean Water (an isotopic water standard defined in 1968 \\ by the International Atomic Energy Agency) \\ WS Westside subbasin study area \\ WSJV Western San Joaquin Valley study unit
}

\section{Organizations}

BOS Branch of Quality Systems (USGS)

$\mathrm{CDPH} \quad$ California Department of Public Health

CDPR California Department of Pesticide Regulation

CDWR California Department of Water Resources

LLNL Lawrence Livermore National Laboratory

NAWQA National Water-Quality Assessment Program (USGS) 


\title{
Abbreviations and Acronyms-Continued
}

\author{
NIST National Institute of Standards and Technology \\ NRP National Research Program (USGS) \\ NWQL National Water Quality Laboratory (USGS) \\ SITL Stable Isotope and Tritium Laboratory, Menlo Park, California (USGS) \\ SWRCB California State Water Resources Control Board \\ TML Trace Metal Laboratory, Boulder, Colorado (USGS) \\ USEPA U.S. Environmental Protection Agency \\ USGS U.S. Geological Survey \\ Weck Weck Laboratories Inc., City of Industry, California

\section{Selected Chemical Names}

\begin{tabular}{|c|c|}
\hline $\mathrm{CaCO}_{3}$ & calcium carbonate \\
\hline $\mathrm{CO}_{3}{ }^{2-}$ & carbonate \\
\hline CFC & chlorofluorocarbon \\
\hline DBCP & 1,2-dibromo-3-chloropropane \\
\hline DOC & dissolved organic carbon \\
\hline EDB & 1,2-dibromoethane \\
\hline EPTC & S-ethyl-dipropylthiocarbamate \\
\hline $\mathrm{H}_{2} \mathrm{O}$ & water \\
\hline $\mathrm{HCl}$ & hydrochloric acid \\
\hline $\mathrm{HCO}_{3}^{-}$ & bicarbonate \\
\hline MTBE & methyl tert-butyl ether \\
\hline $\mathrm{Na}_{2} \mathrm{~S}_{2} \mathrm{O}_{3}$ & sodium thiosulfate \\
\hline NDMA & $N$-nitrosodimethylamine \\
\hline $\mathrm{NO}_{2}^{-}+\mathrm{NO}_{3}^{-}$ & nitrite plus nitrate (as nitrogen) \\
\hline PCE & perchloroethene (tetrachloroethene) \\
\hline $\mathrm{SiO}_{2}$ & silicon dioxide \\
\hline TCE & trichloroethene \\
\hline 1,2,3-ТCP & 1,2,3-trichloropropane \\
\hline TDS & total dissolved solids \\
\hline THM & trihalomethane \\
\hline VOC & volatile organic compound \\
\hline
\end{tabular}




\title{
Groundwater-Quality Data in the Western San Joaquin Valley Study Unit, 2010: Results from the California GAMA Program
}

\author{
By Timothy M. Mathany, Matthew K. Landon, Jennifer L. Shelton, and Kenneth Belitz
}

\section{Abstract}

Groundwater quality in the approximately 2,170 -squaremile Western San Joaquin Valley (WSJV) study unit was investigated by the U.S. Geological Survey (USGS) from March to July 2010, as part of the California State Water Resources Control Board (SWRCB) Groundwater Ambient Monitoring and Assessment (GAMA) Program's Priority Basin Project (PBP). The GAMA-PBP was developed in response to the California Groundwater Quality Monitoring Act of 2001 and is being conducted in collaboration with the SWRCB and Lawrence Livermore National Laboratory (LLNL). The WSJV study unit was the twenty-ninth study unit to be sampled as part of the GAMA-PBP.

The GAMA Western San Joaquin Valley study was designed to provide a spatially unbiased assessment of untreated-groundwater quality in the primary aquifer system, and to facilitate statistically consistent comparisons of untreated groundwater quality throughout California. The primary aquifer system is defined as parts of aquifers corresponding to the perforation intervals of wells listed in the California Department of Public Health (CDPH) database for the WSJV study unit. Groundwater quality in the primary aquifer system may differ from the quality in the shallower or deeper water-bearing zones; shallow groundwater may be more vulnerable to surficial contamination.

In the WSJV study unit, groundwater samples were collected from 58 wells in 2 study areas (Delta-Mendota subbasin and Westside subbasin) in Stanislaus, Merced, Madera, Fresno, and Kings Counties. Thirty-nine of the wells were selected by using a spatially distributed, randomized grid-based method to provide statistical representation of the study unit (grid wells), and 19 wells were selected to aid in the understanding of aquifer-system flow and related groundwaterquality issues (understanding wells).

The groundwater samples were analyzed for organic constituents (volatile organic compounds [VOCs], low-level fumigants, and pesticides and pesticide degradates), constituents of special interest (perchlorate, $N$-nitrosodimethylamine [NDMA], and 1,2,3-trichloropropane [1,2,3-TCP]), and naturally occurring inorganic constituents (trace elements, nutrients, dissolved organic carbon [DOC], major and minor ions, silica, total dissolved solids [TDS], alkalinity, total arsenic and iron [unfiltered] and arsenic, chromium, and iron species [filtered]). Isotopic tracers (stable isotopes of hydrogen, oxygen, and boron in water, stable isotopes of nitrogen and oxygen in dissolved nitrate, stable isotopes of sulfur in dissolved sulfate, isotopic ratios of strontium in water, stable isotopes of carbon in dissolved inorganic carbon, activities of tritium, and carbon-14 abundance), dissolved standard gases (methane, carbon dioxide, nitrogen, oxygen, and argon), and dissolved noble gases (argon, helium-4, krypton, neon, and xenon) were measured to help identify sources and ages of sampled groundwater. In total, 245 constituents and 8 water-quality indicators were measured.

Quality-control samples (blanks, replicates, or matrix spikes) were collected at 16 percent of the wells in the WSJV study unit, and the results for these samples were used to evaluate the quality of the data from the groundwater samples. Blanks rarely contained detectable concentrations of any constituent, suggesting that contamination from sample collection procedures was not a significant source of bias in the data for the groundwater samples. Replicate samples all were within acceptable limits of variability. Matrixspike recoveries were within the acceptable range (70 to 130 percent) for approximately 87 percent of the compounds.

This study did not evaluate the quality of water delivered to consumers. After withdrawal, groundwater typically is treated, disinfected, and (or) blended with other waters to maintain water quality. Regulatory benchmarks apply to water that is delivered to the consumer, not to untreated groundwater. However, to provide some context for the results, concentrations of constituents measured in the untreated groundwater were compared with regulatory and non-regulatory health-based benchmarks established by the U.S. Environmental Protection Agency (USEPA) and CDPH, and to non-regulatory benchmarks established for aesthetic concerns by CDPH. Comparisons between data collected for this study and benchmarks for drinking water are for illustrative purposes only and are not indicative of compliance or non-compliance with those benchmarks. 
Most inorganic constituents detected in groundwater samples from the 39 grid wells were detected at concentrations less than health-based benchmarks. Detections of organic and special-interest constituents from grid wells sampled in the WSJV study unit also were less than health-based benchmarks.

In total, VOCs were detected in 12 of the 39 grid wells sampled (approximately 31 percent), pesticides and pesticide degradates were detected in 9 grid wells (approximately 23 percent), and perchlorate was detected in 15 grid wells (approximately 38 percent).

Trace elements, major and minor ions, and nutrients were sampled for at 39 grid wells; most concentrations were less than health-based benchmarks. Exceptions include two detections of arsenic greater than the USEPA maximum contaminant level (MCL-US) of 10 micrograms per liter $(\mu \mathrm{g} / \mathrm{L}), 20$ detections of boron greater than the $\mathrm{CDPH}$ notification level (NL-CA) of 1,000 $\mu \mathrm{g} / \mathrm{L}, 2$ detections of molybdenum greater than the USEPA lifetime health advisory level (HAL-US) of $40 \mu \mathrm{g} / \mathrm{L}, 1$ detection of selenium greater than the MCL-US of $50 \mu \mathrm{g} / \mathrm{L}, 2$ detections of strontium greater than the HAL-US of $4,000 \mu \mathrm{g} / \mathrm{L}$, and 3 detections of nitrate greater than the MCL-US of $10 \mu \mathrm{g} / \mathrm{L}$.

Results for inorganic constituents with non-healthbased benchmarks (iron, manganese, chloride, sulfate, and TDS) showed that iron concentrations greater than the CDPH secondary maximum contaminant level (SMCL-CA) of $300 \mu \mathrm{g} / \mathrm{L}$ were detected in five grid wells. Manganese concentrations greater than the SMCL-CA of $50 \mu \mathrm{g} / \mathrm{L}$ were detected in 16 grid wells. Chloride concentrations greater than the recommended SMCL-CA benchmark of 250 milligrams per liter $(\mathrm{mg} / \mathrm{L})$ were detected in 14 grid wells, and concentrations in 5 of these wells also were greater than the upper SMCL-CA benchmark of $500 \mathrm{mg} / \mathrm{L}$. Sulfate concentrations greater than the recommended SMCL-CA benchmark of $250 \mathrm{mg} / \mathrm{L}$ were measured in 21 grid wells, and concentrations in 13 of these wells also were greater than the SMCL-CA upper benchmark of $500 \mathrm{mg} / \mathrm{L}$. TDS concentrations greater than the SMCL-CA recommended benchmark of $500 \mathrm{mg} / \mathrm{L}$ were measured in 36 grid wells, and concentrations in 20 of these wells also were greater than the SMCL-CA upper benchmark of 1,000 mg/L.

\section{Introduction}

About one-half of the water used for public and domestic drinking-water supply in California is groundwater (Kenny and others, 2009). To assess the quality of ambient groundwater in aquifers used for public drinking-water supply and to establish a baseline groundwater-quality monitoring program, the California State Water Resources Control Board (SWRCB), in cooperation with the U.S. Geological Survey (USGS) and Lawrence Livermore National Laboratory (LLNL), implemented the Groundwater Ambient Monitoring and Assessment (GAMA) Program in 2000 (California
Environmental Protection Agency, 2011, Web site at http:// www.waterboards.ca.gov/water_issues/programs/gama/). The main goals of the GAMA Program are to improve groundwater monitoring and to increase the availability of groundwater-quality data to the public. The GAMA Program currently consists of four projects: (1) the GAMA Priority Basin Project (PBP) conducted by the USGS (U.S. Geological Survey, 2011a, California Water Science Center Web site at http://ca.water.usgs.gov/gama/); (2) the GAMA Domestic Well Project conducted by the SWRCB; (3) GAMA Special Studies conducted by LLNL; and (4) GeoTracker GAMA, conducted by the SWRCB. The GAMA-PBP primarily focuses on the deep part of the groundwater resource, which is typically used for public drinking-water supply. The GAMA Domestic Well Project generally focuses on the shallow aquifer systems, which may be particularly at risk as a result of surficial contamination. The GAMA Special Studies Project focuses on using research methods to help explain the source, fate, transport, and occurrence of chemicals that can affect groundwater quality. GeoTracker GAMA is an online interface serving data from the GAMA Program and other efforts to the public (http://geotracker.waterboards.ca.gov/).

The GAMA Program was initiated by the SWRCB in 2000 and later expanded by the Groundwater Quality Monitoring Act of 2001 (State of California, 2001a, b; Sections 10780-10782.3 of the California Water Code, Assembly Bill 599). The GAMA-PBP assesses groundwater quality in key groundwater basins that account for more than 90 percent of all groundwater used for public supply in the State. For the GAMA-PBP, the USGS, in collaboration with the SWRCB, developed the monitoring plan to assess groundwater basins through direct and other statistically reliable sample approaches (Belitz and others, 2003; California State Water Resources Control Board, 2003). Additional partners in the GAMA-PBP include LLNL, California Department of Public Health (CDPH), California Department of Water Resources (CDWR), California Department of Pesticide Regulation (CDPR), local water agencies, and well owners (Kulongoski and Belitz, 2004). Participation in the GAMA-PBP is entirely voluntary.

The GAMA-PBP is unique in California because it includes many chemical analyses that are not otherwise available in the statewide water-quality monitoring datasets. Groundwater samples collected for the GAMA-PBP are analyzed for approximately 300 chemical constituents using methods with lower detection limits than required by the $\mathrm{CDPH}$ for regulatory monitoring of water from drinking-water wells. These analyses will be especially useful for providing an early indication of changes in groundwater quality. In addition, the GAMA-PBP analyzes samples for a suite of constituents more extensive than required by $\mathrm{CDPH}$ and for a suite of chemical and isotopic tracers for understanding hydrologic and geochemical processes. This understanding of groundwater composition is useful for identifying the natural and human factors affecting water quality. Understanding 
the occurrence and distribution of chemical constituents of significance to water quality is important for the long-term management and protection of groundwater resources.

The range of hydrologic, geologic, and climatic conditions in California must be considered in an assessment of groundwater quality. Belitz and others (2003) partitioned the State into 10 hydrogeologic provinces, each with distinctive hydrologic, geologic, and climatic characteristics: Cascades and Modoc Plateau, Klamath Mountains, Northern Coast Ranges, Central Valley, Sierra Nevada, Basin and Range, Southern Coast Ranges, Transverse Ranges and selected Peninsular Ranges, Desert, and San Diego Drainages (fig. 1). These 10 hydrogeologic provinces include groundwater basins and subbasins designated by the CDWR (California Department of Water Resources, 2003). The lithology of the groundwater basins and subbasins generally consist of relatively permeable, unconsolidated deposits of alluvial or volcanic origin. Eighty percent of California's approximately 16,000 active and standby drinking-water wells listed in the statewide database maintained by the CDPH (hereinafter referred to as CDPH wells) are located in groundwater basins and subbasins within the 10 hydrogeologic provinces. Groundwater basins and subbasins were prioritized for sampling on the basis of the number of CDPH wells in the basin, with secondary consideration given to municipal groundwater use, agricultural pumping, the number of formerly leaking underground fuel tanks, and the number of registered pesticide applications (Belitz and others, 2003). Of the 472 basins and subbasins designated by the CDWR, 116 priority basins were selected and grouped into 35 GAMA study units, representing approximately 95 percent of the CDPH wells in California. In addition, some areas outside of the defined groundwater basins were included in the adjacent study unit to achieve representation of the 20 percent of the $\mathrm{CDPH}$ wells not located in the groundwater basins.

The data collected in each study unit are used for three types of water-quality assessments: (1) Statusassessment of the current quality of the groundwater resource; (2) Understanding-identification of the natural and human factors affecting groundwater quality; and (3) Trends - detection of changes in groundwater quality over time (Kulongoski and Belitz, 2004). The assessments are intended to characterize the quality of groundwater in the primary aquifer systems of the study units, not the treated drinking water delivered to consumers by water purveyors.
The primary aquifer systems are defined as parts of aquifers corresponding to the perforation intervals of wells listed in the $\mathrm{CDPH}$ databases for the study units. The $\mathrm{CDPH}$ database lists wells used for municipal and community drinking-water supplies, and includes wells from systems classified as nontransient (such as those in cities, towns, and mobile-home parks) and transient (such as those in schools, campgrounds, and restaurants). Collectively, the CDPH refers to these wells as "public-supply" wells. Groundwater quality in the primary aquifers may differ from the quality in the shallow or deep parts of the aquifer system. In particular, shallow groundwater may be more vulnerable to surface contamination. As a result, samples from shallow wells (such as many private domestic wells and groundwater monitoring wells) can have greater concentrations of constituents (such as volatile organic compounds [VOCs] and nitrate) from anthropogenic sources than samples from wells screened in the underlying primary aquifer systems (Landon and others, 2010).

All published analytical data and quality-assurance/ quality-control (QA/QC) data collected for the GAMA Program are stored in the web-based Geotracker Database (California State Water Resources Control Board, 2009, website at https://geotracker.waterboards.ca.gov/gama/). The Geotracker Database also stores groundwater-quality data and related reports collected by other State agencies, such as the CDPH, CDWR, CDPR, and data collected by the SWRCB and Regional Boards from groundwater monitoring wells at contaminated or remediated sites.

The Western San Joaquin Valley study unit (hereinafter referred to as the WSJV study unit) lies within the Central Valley hydrogeologic province described by Belitz and others (2003) (fig. 1). Groundwater is a major source of public drinking-water supply for many of the communities located in the WSJV study unit (Water Education Foundation, 2006); therefore, the WSJV study unit was considered high priority for sampling to provide adequate representation of the Central Valley hydrogeologic province.

This USGS Data Series Report is one of a series of reports presenting the water-quality data collected by the USGS in the WSJV study unit for the GAMA-PBP. Data Series Reports for each of the GAMA-PBP study units are available from the U.S. Geological Survey (2011b), at http://ca.water.usgs.gov/projects/gama/includes/GAMA publications.html. 


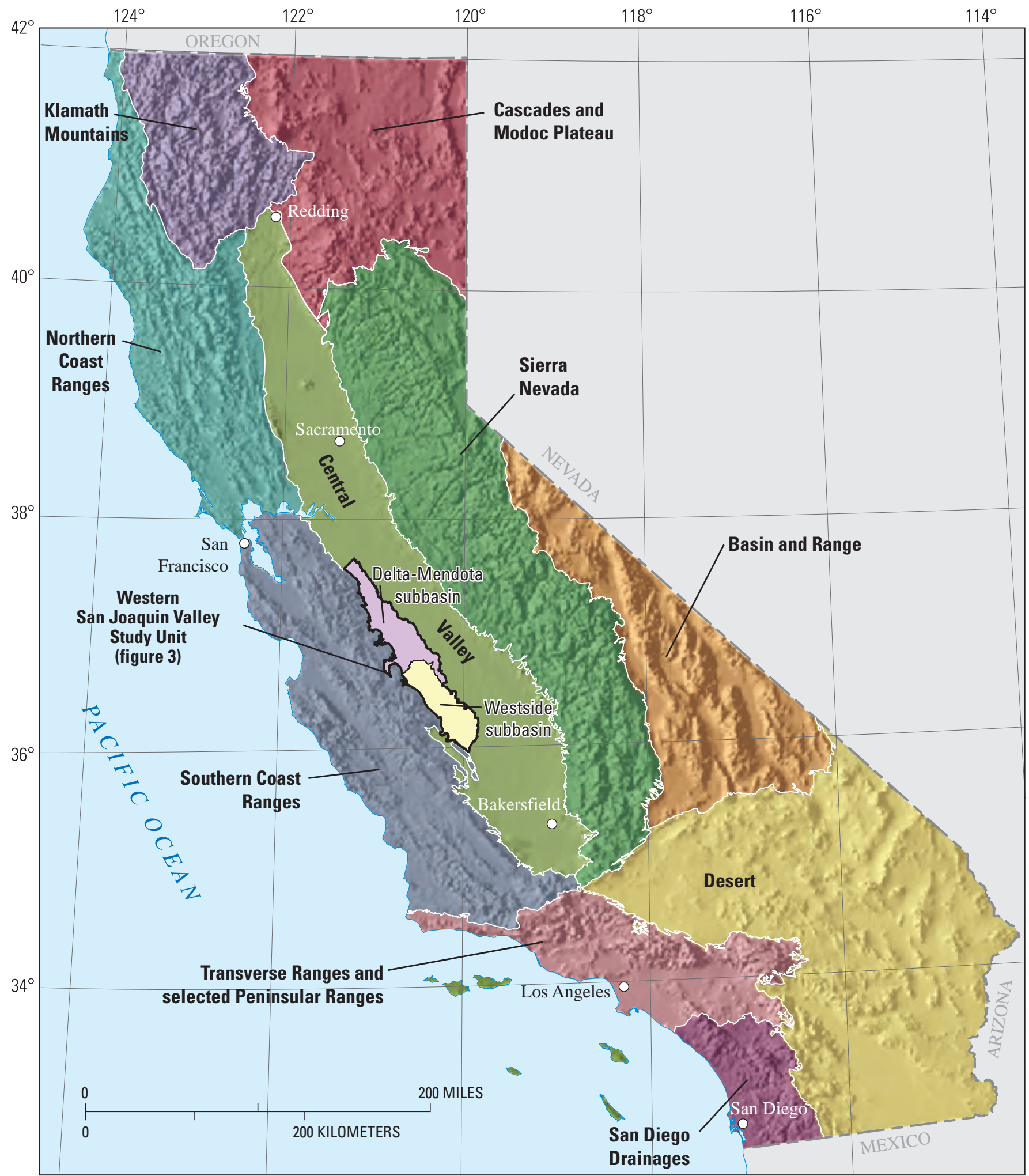

Shaded relief derived from U.S. Geological Survey

Provinces from Belitz and others, 2003.

National Elevation Dataset, 2006

Albers Equal Area Conic Projection

Figure 1. Hydrogeologic provinces of California and the location of the Western San Joaquin Valley (WSJV) Groundwater Ambient Monitoring and Assessment (GAMA) study unit. 


\section{Purpose and Scope}

The purposes of this report are to describe (1) the hydrogeologic setting of the WSJV study unit, the study design, and the study methods; (2) the analytical results for groundwater samples collected in the WSJV study unit, and (3) the results of QC analysis. Groundwater samples were analyzed for water-quality indicators; organic, special-interest, and inorganic constituents; isotopic tracers; and dissolved gases. The chemical data presented in this report were evaluated by comparison to State and Federal drinking-water standards. The health-based and non-health based benchmarks considered for this report are those established by the U.S. Environmental Protection Agency (USEPA) and (or) the $\mathrm{CDPH}$. Discussion of the factors that influence the distribution and occurrence of the constituents detected in groundwater samples will be the subject of subsequent publications.

\section{Hydrogeologic Setting}

The WSJV study unit is located in the western part of the Central Valley and includes two CDWR-defined San Joaquin Valley groundwater subbasins: Delta-Mendota and Westside (California Department of Water Resources, 2003). Combined, these subbasins define the extent of the WSJV study unit and cover an area of approximately 2,170 square miles $\left(\mathrm{mi}^{2}\right)$ in Stanislaus, Merced, Madera, Fresno, and Kings Counties, California (fig. 2). The study unit is bounded by the Southern Coast Ranges, the Stanislaus/San Joaquin county line, and numerous CDWR-defined subbasins (California Department of Water Resources, 2006a, b) (fig. 2).

The climate in the study unit is classified as Mediterranean, arid to semiarid, with hot, dry summers and cool, moist winters (U.S. Department of Commerce, National Climatic Data Center, 2010). Average rainfall across the study unit ranges from 6 inches (in.) in the southern parts of the Westside subbasin study area to $12 \mathrm{in.}$ in the northern parts of the Delta-Mendota subbasin study area (PRISM Climate Group, Oregon State University, 2010). Approximately 85 to 90 percent of annual precipitation occurs as rainfall during November through April (Western Regional Climate Center, 2011).

The primary aquifer system in the study unit occurs in unconsolidated alluvial and continental deposits of the Tulare Formation (Hotchkiss and Balding, 1971; Belitz and Heimes, 1990; California Department of Water Resources, 2006a, b). The Tulare Formation is composed of mostly unconsolidated clay, silt, sand, and gravel of Pliocene and Pleistocene age. The Corcoran Clay Member of the Tulare Formation acts as the major restrictive structure to vertical groundwater and is found at depths of about 100 to 850 feet (ft) throughout the study unit (California Department of Water Resources, 2006a, b). The Corcoran Clay occurs in the subsurface throughout the study unit except along the western and eastern margins where the Quaternary alluvial and continental sediments pinch out (fig. 2).

The upper part of the Tulare Formation above the Corcoran Clay can be unconfined, semi-confined, or confined, as a result of the presence of many discontinuous lenses of clay and silt that occur throughout the alluvial and continental deposits (Hotchkiss and Balding, 1971). In the upper zone, groundwater flow is typically from the San Joaquin Valley margins towards the valley center and from south to north, following the elevation trend of the valley (Hotchkiss and Balding, 1971; Faunt, 2009).

The lower part of the Tulare Formation below the Corcoran Clay is confined (Belitz and Heimes, 1990). This lower zone is underlain by saline water that may be influenced by interactions with marine sediments at greater depths. In the lower zone, groundwater flow in the system is predominantly towards the western margin of the San Joaquin Valley, but is strongly influenced by local variations in pumping stress (Belitz and Heimes, 1990; Faunt, 2009).

On the basis of differences in textures, hydrologic properties, and oxidation states, the unconsolidated deposits in the semi-confined to unconfined zone of the Tulare Formation can be divided into two major hydrogeologic units: Coast Ranges alluvium and Sierran sands (Belitz and Heimes, 1990).

The Coast Ranges alluvium (mapped as Quaternary alluvium on fig. 2), derived from the Coast Ranges to the west, is generally oxidized, and ranges in thickness from $850 \mathrm{ft}$ along the Coast Ranges to $0 \mathrm{ft}$ in the eastern edge of the study unit (Belitz and Heimes, 1990). The Coast Ranges alluvium was deposited in a series of coalescing alluvial fans from streams draining the Coast Ranges. Sediments deposited near the fan head, where the stream enters the valley, are typically the coarsest, and sediment texture generally becomes finer with increasing distance from the fan head and stream channels (Belitz and Heimes, 1990).

The Sierran sands (mapped as Quaternary other sediments on fig. 2) predominantly consist of well-sorted micaeous sand that is derived from the Sierra Nevada to the east. These deposits are up to 400-500 ft thick in the San Joaquin Valley trough and thin to the west, where they interfinger with the Coast Ranges alluvium. The Sierran sands are highly permeable and predominantly chemically reduced in the valley trough (Belitz and Heimes, 1990). The reduced sediments are gray-green, whereas oxidized sediments are yellow, orange, or brown as a result of oxidation of iron minerals in the sediments (Davis and others, 1959; Hotchkiss and Balding, 1971).

In addition to the Coast Ranges alluvium and Sierran sands, continental deposits and non-marine and marine sediments (mapped as Tertiary deposits and sediments on fig. 2) occur along the western margin of the study unit. These deposits are generally located above modern streambeds or the water table, but have coarse texture that may contribute to groundwater recharge along the western margin of the study unit (Hotchkiss and Balding, 1971). 


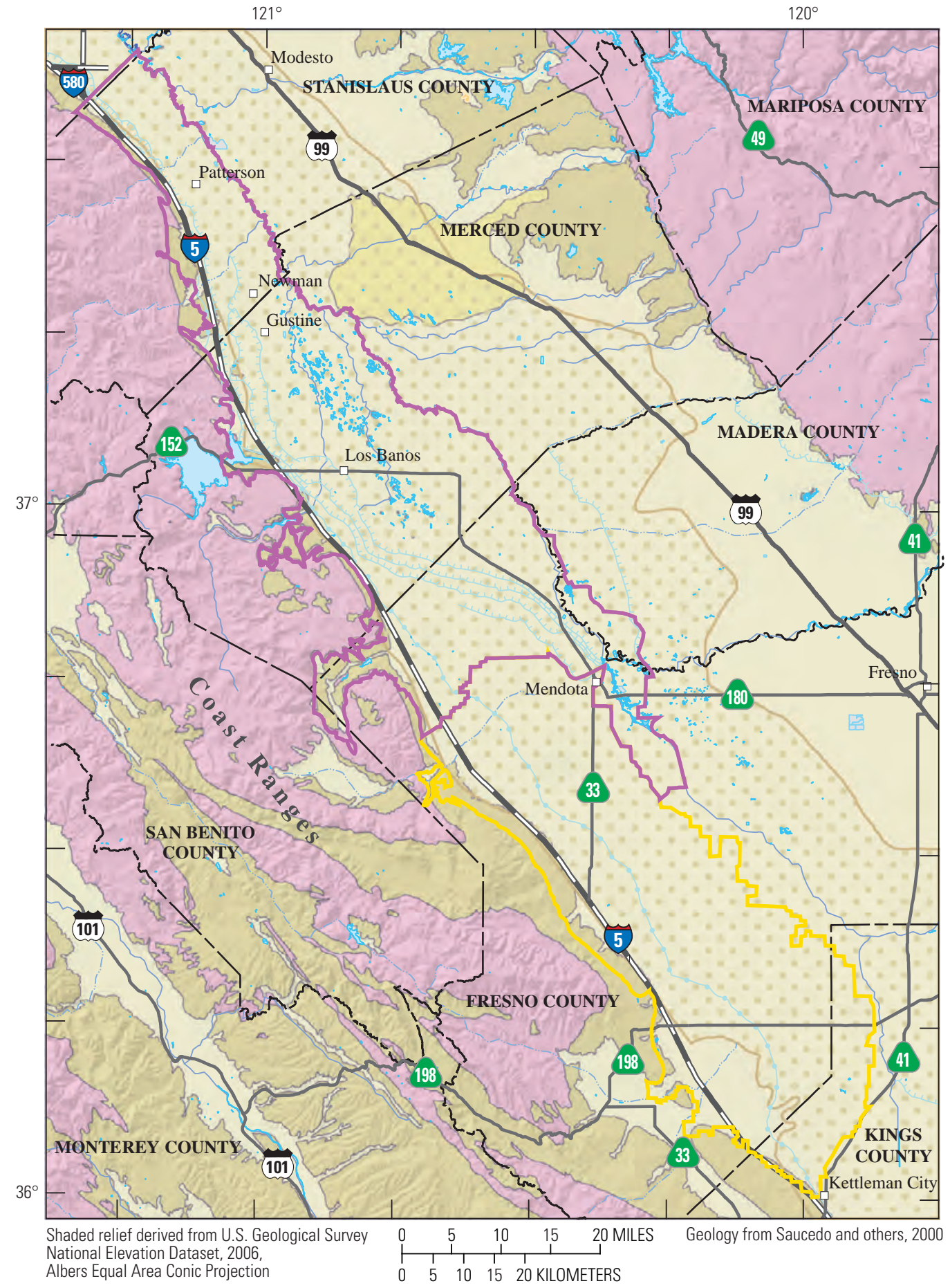

EXPLANATION

Extent of the Pleistocene-age Corcoran Clay member of the Tulare Formation

Quaternary alluvium

Quaternary other sediments
Tertiary deposits and sediments

Mesozoic and Paleozoic igneous and metamorphic rocks
Delta-Mendota subbasin study area

Westside subbasin study area

Figure 2. Boundaries of the Delta-Mendota (DM) subbasin and the Westside (WS) subbasin study areas, geologic formations, major cities, major roads, and hydrologic features. 


\section{Western San Joaquin Valley Study Unit- Delta-Mendota Subbasin Study Area}

The Delta-Mendota subbasin study area (hereinafter referred to as the DM study area) is $1,170 \mathrm{mi}^{2}$ in area and lies in the northwestern part of the San Joaquin Valley (fig. 3). The DM study area mostly lies between the San Joaquin River near the San Joaquin Valley trough on the east and the Coast Ranges on the west. The study area is approximately 90 miles (mi) long from southeast to northwest parallel to the San Joaquin Valley axis and is 6 to $28 \mathrm{mi}$ wide from the southwest valley margin to the San Joaquin River in the northeast. The city of Los Banos is the only community in the study area with a population greater than 10,000 people and had an estimated 2006 population of 34,717 (U.S. Census Bureau, 2011).

Land-surface altitudes in the study area range from approximately 30 feet above mean sea level ( $\mathrm{ft}$ above msl) near the northeastern corner, to about $1,500 \mathrm{ft}$ above msl near the southwestern corner; most of the study area has a land surface less than $150 \mathrm{ft}$ above msl. The San Joaquin River at the eastern edge of the study area is the largest surface drainage feature in the study area and interacts with groundwater (forming wetlands) in the eastern part of the study area. Numerous small streams that flow intermittently after rainstorms drain from the Coast Ranges to the east into the study area. However, only Orestimba and Los Banos Creeks maintain channels to the San Joaquin River. When flowing, these tributary streams lose most of their water to seepage and evaporation before reaching the San Joaquin River (Hotchkiss and Balding, 1971). Water is imported into the study area from the Sacramento-San Joaquin Rivers Delta to the north through the Delta-Mendota canal, which runs the length of the study area from northwest to southeast, and through the San Luis Canal, which runs along the western edge of the San Joaquin Valley. Water is also imported from the San Joaquin River (Mendota Pool) at the southeast corner of the study area by way of the Outside, Main, and Chowchilla canals (ig. 3 ).

Groundwater recharge in the study area primarily occurs from the percolation of agricultural return (from applied surface water and groundwater used for irrigation). To a lesser extent, ambient recharge also occurs from seepage losses along the San Joaquin River and infiltration of runoff from the Coast Ranges into tributary streams. Groundwater discharge from the study area is primarily due to groundwater pumping and subsurface outflow to other parts of the San Joaquin Valley (California Department of Water Resources, 2006a, b; Faunt, 2009).

\section{Western San Joaquin Valley Study Unit- Westside Subbasin Study Area}

The Westside subbasin study area (hereinafter referred to as the WS study area) is $1,000 \mathrm{mi}^{2}$ in area and lies in the southwestern part of the San Joaquin Valley (fig. 3). The WS study area and groundwater subbasin correspond to the boundaries of the Westlands Water District (California Department of Water Resources, 2006b). The study area is approximately $60 \mathrm{mi}$ long from southeast to northwest parallel to the San Joaquin Valley axis and is 13 to $24 \mathrm{mi}$ wide from the southwest valley margin to the northeastern boundary. There are no communities in the study area with a population greater than 10,000 people (U.S. Census Bureau, 2011).

Land-surface altitudes in the study area range from approximately $160 \mathrm{ft}$ above msl near the northeastern corner of the study area to about 1,400 ft above msl near the western margin of the study area; most of the study area has land-surface altitudes less than $500 \mathrm{ft}$ above msl. The major surface-water features in the study area are the California Aqueduct and numerous streams that intermittently flow after rainstorms from the Coast Ranges into the study area. The largest of these intermittent streams are the Panoche, Los Gatos, and Zapato Chino Creeks. When flowing, these streams usually lose their water to seepage and evaporation before reaching the San Joaquin River (Belitz and Heimes, 1990). Since about 1967, water has been imported into the study area from the Sacramento-San Joaquin Rivers Delta to the north through the California Aqueduct (fig. 3).

Under current conditions, groundwater recharge in the study area is primarily from irrigation return flow, with lesser amounts of infiltration of runoff from the Coast Ranges along tributary streams. Subsurface groundwater inflow from adjacent groundwater subbasins also occurs (Faunt, 2009). Groundwater discharge from the study area is primarily due to groundwater pumping (California Department of Water Resources, 2006a, b; Faunt, 2009). Under predevelopment conditions, groundwater recharge in the study area was primarily from infiltration of stream water draining the Coast Ranges, and groundwater discharge was primarily by evapotranspiration and streamflow along the San Joaquin Valley trough (Belitz and Heimes, 1990). 


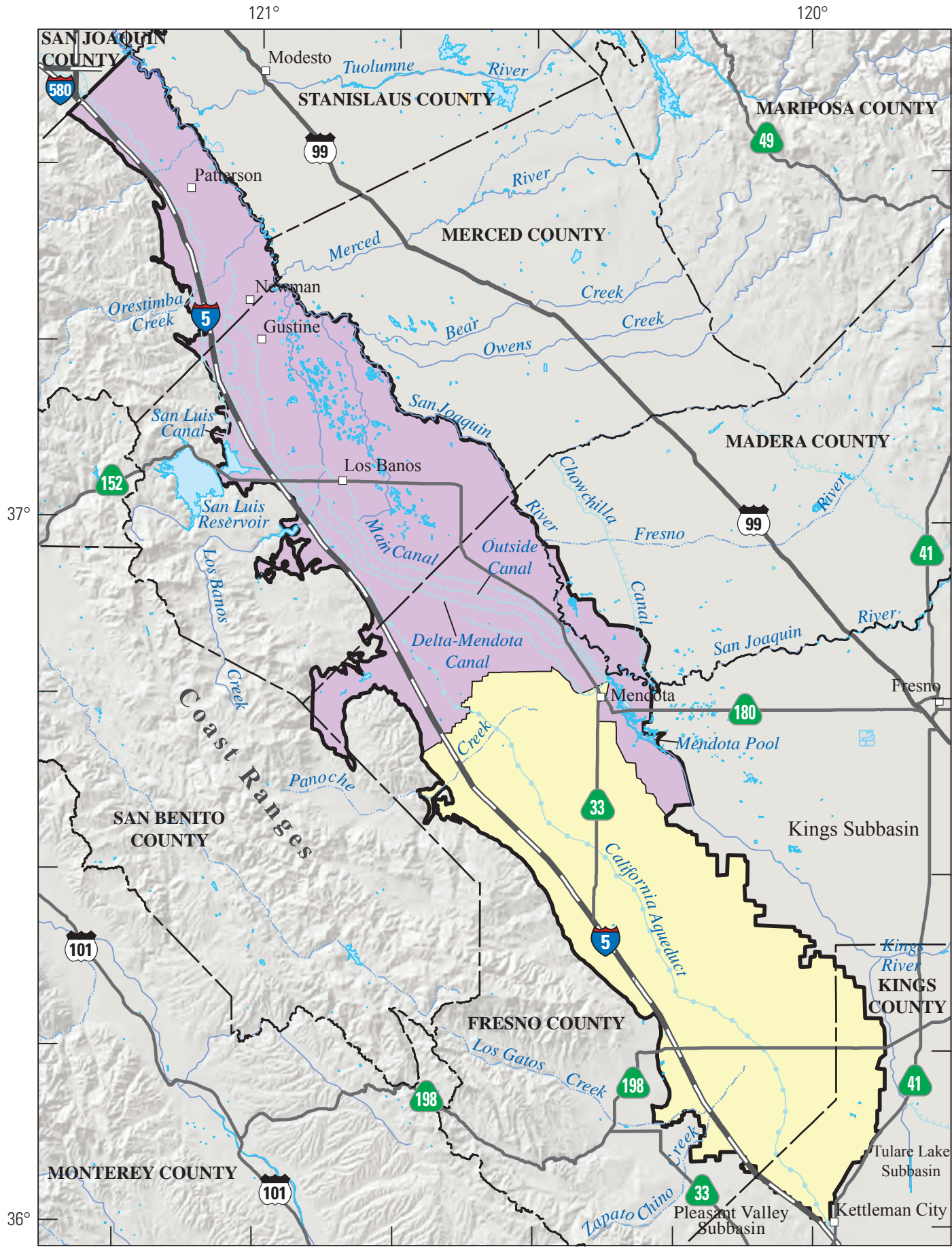

Shaded relief derived from U.S. Geological Survey National Elevation Dataset, 2006,

Albers Equal Area Conic Projection

\section{EXPLANATION}

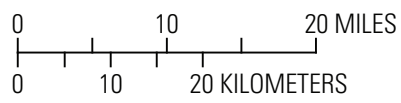

STUDY AREA
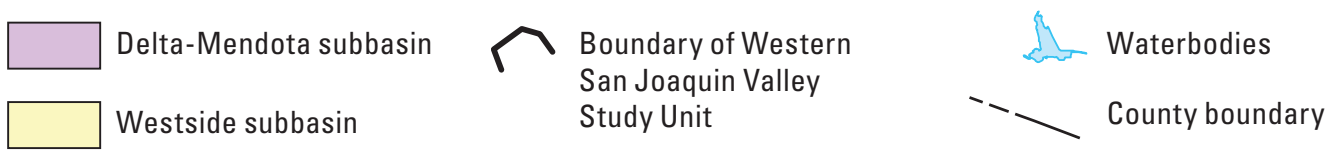

Figure 3. The Delta-Mendota (DM) subbasin and the Westside (WS) subbasin study areas, and the boundaries of the California Department of Water Resources (CDWR) defined groundwater subbasins. 


\section{Methods}

Methods used for the GAMA-PBP were selected to achieve the following objectives: (1) design a sampling plan for suitable statistical representation; (2) collect samples in a consistent manner; (3) analyze samples by using proven and reliable laboratory methods; (4) assure the quality of the groundwater data; and (5) maintain data securely and with relevant documentation. The appendix contains detailed descriptions of the sample-collection protocols and analytical methods, the QA plan, and the results of analyses of QC samples.

\section{Study Design}

The wells selected for sampling in this study reflect the combination of two well-selection strategies. For the first strategy, 39 randomized wells were selected to provide a statistically unbiased, spatially distributed assessment of the quality of groundwater resources used for public drinking-water supply. Wells sampled as part of the spatially distributed, randomized grid-cell network, hereinafter, are referred to as "grid wells." For the second strategy, 19 nonrandomized wells (hereinafter referred to as "understanding wells") were sampled in the DM and WS study areas to aid in the understanding of aquifer-system flow and related groundwater-quality issues.

The spatially distributed wells were selected using a randomized grid-based method (Scott, 1990). The randomized grid-based method divides the study unit into equal-area grid cells; however, geographic features may force a grid cell to be divided into multiple pieces to obtain the designated coverage area for each cell. For instance, a part of a grid cell may be separated by a mountain range, but the sum of the cell parts is still considered one grid cell.

In the WSJV study unit, the approach was to sample one available CDPH well located within each grid cell. If a grid cell contained more than one CDPH well, each well randomly was assigned a rank. The highest ranking well that met basic sampling criteria (for example, sampling point located prior to treatment or capability to pump for several hours) was sampled. If a grid cell contained no accessible CDPH wells, then other types of wells, such as irrigation, domestic, and (or) commercial wells were considered for sampling. These non-CDPH wells were identified from USGS databases or by door-to-door canvassing. Wells with depths and screened intervals similar to CDPH wells in the area were selected. In this fashion, one well was selected for possible sampling in each cell to provide a spatially distributed, randomized monitoring network.

The DM study area was divided into 30 equal-area grid cells of approximately $38.9 \mathrm{mi}^{2}$ (approximately 100 square kilometers $\left[\mathrm{km}^{2}\right]$ ) in area each; wells in 29 of the 30 grid cells were sampled (figs. 4, 5). The WS study area was divided into 10 equal-area grid cells of approximately $38.9 \mathrm{mi}^{2}$ (approximately $100 \mathrm{~km}^{2}$ ) in area each; wells in all 10 grid cells were sampled.

The design of the grid cells differed between the DM and WS study areas because of differences in the distributions and prevalence of CDPH wells. In the DM study area, the entire study area is divided into 30 equal-area cells. Most of the cells within the study area contain CDPH wells; 149 CDPH wells are in the study area (fig. 4). Consistent with GAMA-PBP design in other study units with many CDPH wells, the grid cells cover the entire study area.

In contrast, the WS study area had only $16 \mathrm{CDPH}$ wells (fig. 4). Therefore, our approach involved using circular buffer areas around each CDPH well to delineate the grid cells was used. This allowed assessment of the part of the primary aquifer that is currently used for water supply. This strategy has been used in other GAMA-PBP study units with few and (or) unevenly distributed CDPH wells (Bennett and others, 2009; Schmitt and others, 2009). Buffer areas in the WS study area (within the WSJV study unit) have a radius of about $4 \mathrm{mi}$ (fig. 5).

The 39 grid wells sampled in the WSJV study unit were numbered in the order in which samples were collected in each study area with the prefix varying by study area: "DM" for the Delta-Mendota subbasin and "WS" for the Westside subbasin (fig. 5). A grid well could not be located in one WS grid cell, so an available CDPH well located slightly outside of the study area boundary (WS-09, fig. 5) was sampled. Although the CDPH well was situated $1.3 \mathrm{mi}$ away from the boundary of the WS study area, it was close to the eastern boundary and was considered to be representative of groundwater quality in the eastern part of the WS study area.

The 19 understanding wells sampled as part of the study were not included in the statistical characterization of water quality in the WSJV study unit because inclusion of these wells would lead to the overrepresentation of some cells. These additional wells were numbered in the order of sample collection, with the prefix modified from those used by the grid cells: "DM-U" or "WS-U" ("U" indicates "understanding") (fig. 5). Of the understanding wells, 15 were short-screened monitoring wells open at different depths in the aquifer system at 6 geographic locations. The monitoring wells were sampled for the purpose of understanding vertical differences in groundwater quality and age in these six different parts of the WSJV study unit.

The GAMA alphanumeric identification number for each well, along with the date sampled, sampling schedule, landsurface altitude, well type, and available well-construction information is shown in table 1. Groundwater samples were collected during the period from March to July 2010. Grid wells included $18 \mathrm{CDPH}$ wells, 10 irrigation wells, 8 domestic wells, 1 institutional well, and 2 unused wells. Understanding wells included 15 monitoring wells, $3 \mathrm{CDPH}$ wells, and 1 domestic well. 


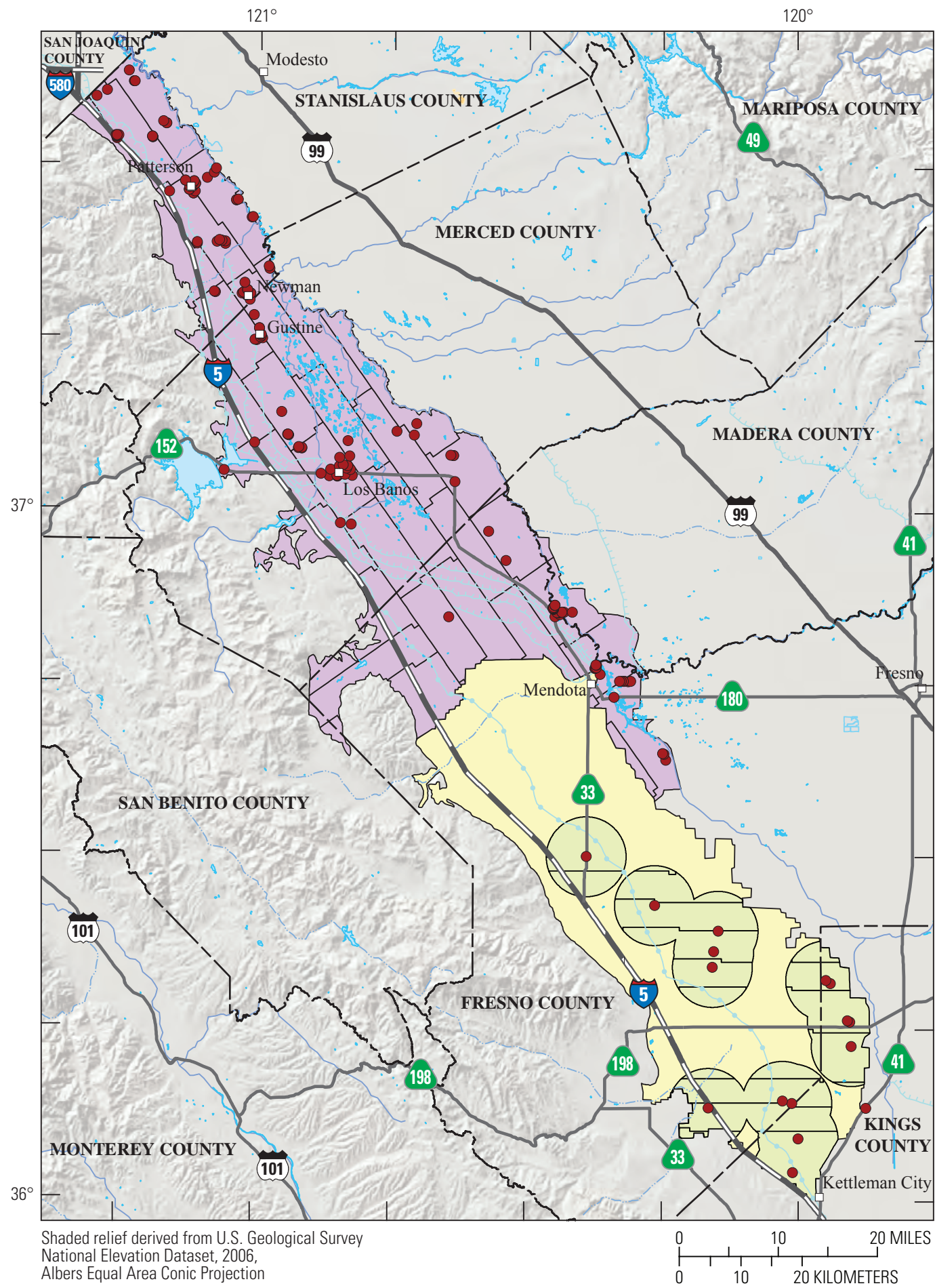

EXPLANATION
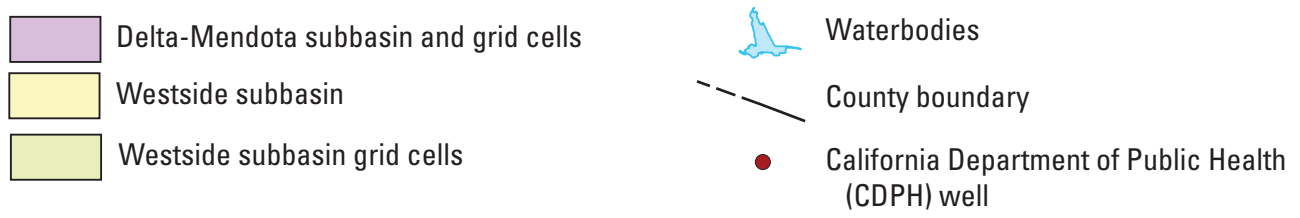

Figure 4. The Delta-Mendota (DM) subbasin and the Westside (WS) subbasin study areas, the distribution of the grid cells, and the location of California Department of Public Health (CDPH) wells. 


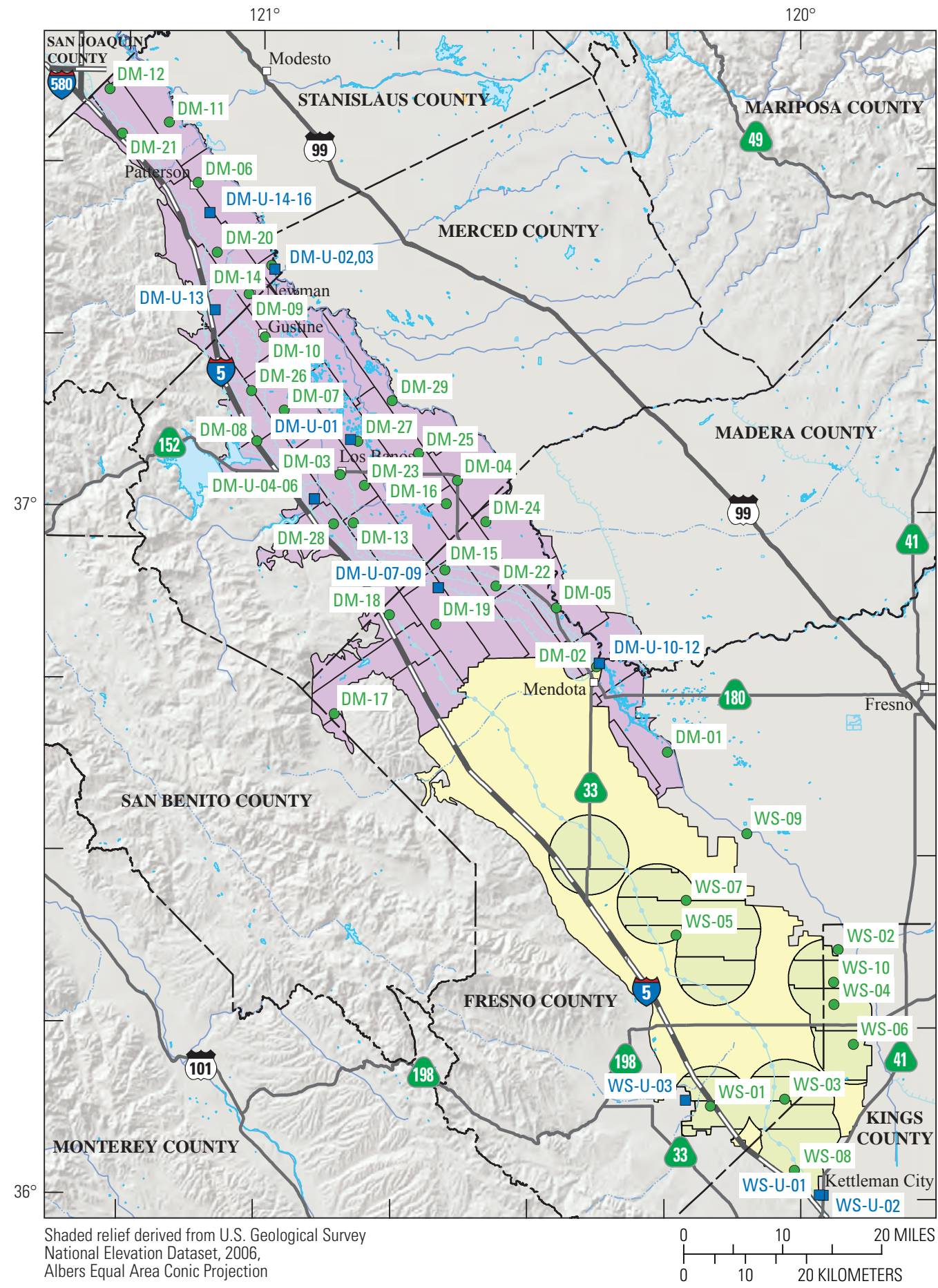

EXPLANATION

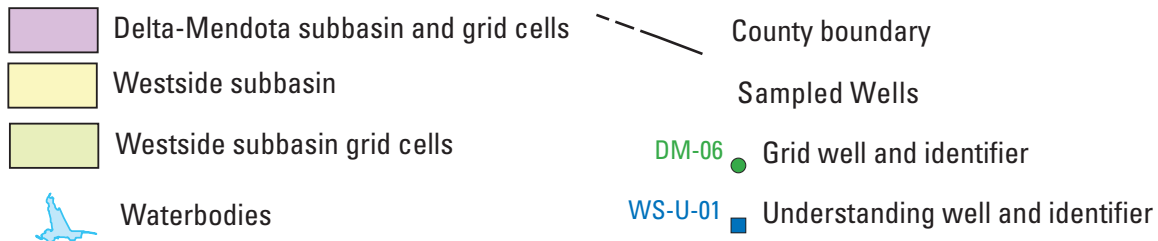

Figure 5. The Delta-Mendota (DM) subbasin and the Westside (WS) subbasin study areas, the distribution of the grid cells, and the location of sampled grid and understanding wells. 
Well locations were verified by using a global positioning system (GPS), 1:24,000-scale USGS topographic maps, comparison with existing well information in USGS and CDPH databases, and information provided by well owners, drillers' logs, and (or) other sources of construction information. Well location and information were recorded in the field on field sheets, and electronically on field laptop computers using the Alternate Place Entry (APE) program designed by the USGS. All information was verified and then uploaded into the USGS National Water Information System (NWIS) database. Well location, well owner, and well-use information is confidential.

The wells in the WSJV study unit were sampled by using a tiered analytical approach. All wells were sampled for a standard set of constituents: VOCs, low-level fumigants, pesticides and pesticide degradates, perchlorate, 1,2,3-trichloropropane (1,2,3-TCP), trace elements, nutrients, major and minor ions, silica, total dissolved solids (TDS), total arsenic and iron (unfiltered), arsenic and iron species (filtered), stable isotopes of hydrogen and oxygen in water, stable isotopes of carbon in dissolved inorganic carbon and carbon-14 abundance, activities of tritium, and dissolved noble gases. The standard set of constituents was termed the "intermediate" sampling schedule (table 2). Wells on the "slow" sampling schedule included all of the constituents on the intermediate sampling schedule, plus $\mathrm{N}$-nitrosodimethylamine (NDMA), dissolved organic carbon (DOC), field alkalinity, chromium species (filtered), stable isotopes of nitrogen and oxygen in dissolved nitrate, stable isotopes of sulfur in dissolved sulfate, stable isotopes of boron in water, isotopic ratios of strontium in water, and dissolved standard gases.

Intermediate and slow refer to the relative time required to sample the well for all constituents on the schedule. Three intermediate or two slow wells generally could be sampled in 1 day. In the WSJV study unit, 25 of the wells were sampled on the intermediate sampling schedule ( 24 grid and 1 understanding), and 33 wells were sampled on the slow sampling schedule (15 grid and 18 understanding) (table 1).

\section{Sample Collection and Analysis}

Samples were collected by using USGS National Field Manual (NFM) (U.S. Geological Survey, variously dated) and modified USGS National Water-Quality Assessment (NAWQA) Program (Koterba and others, 1995) sampling protocols. These sampling protocols were followed so that samples representative of groundwater in the aquifer were collected at each site, and so that the samples were collected and handled in ways that minimized the potential for contamination; this will also allow comparison with data collected by GAMA-PBP throughout California and with other USGS projects in California and the Nation.

Groundwater samples were analyzed for 85 VOCs (table 3A); 2 low-level fumigants (table 3B); 83 pesticides and pesticide degradates (table 3C); 3 constituents of special interest (table 3D); 24 trace elements (table 3E); 5 nutrients and DOC (table 3F); 9 major and minor ions, silica, TDS, and alkalinity (table 3G); total arsenic and iron (unfiltered) and arsenic, chromium, and iron species (filtered) (table 3H), 8 stable isotopes, carbon-14 abundance, activities of tritium, 11 dissolved standard and noble gases, and helium stable isotopic ratios (table 3I). The methods used for sample collection and analysis are described in the appendix section titled "Sample Collection and Analysis."

\section{Data Reporting}

Many of the constituents presented in this report have different laboratory reporting conventions; some of the constituents were analyzed by seperate analytical laboratories or methods. The appendix section titled "Data Reporting" gives details for the laboratory reporting conventions for all constituents and the method preferences for those constituents that were analyzed by multiple methods or by multiple laboratories in the WSJV study unit.

\section{Quality-Assurance Methods}

The QA/QC procedures used for this study followed the protocols described in the NFM (U.S. Geological Survey, variously dated) and used by the NAWQA Program (Koterba and others, 1995). The QA plan followed by the USGS National Water Quality Laboratory (NWQL), the primary laboratory used to analyze samples for this study, is described in Pirkey and Glodt (1998) and Maloney (2005). QC samples collected in the WSJV study unit are blanks, replicates, and matrix and surrogate spikes. QC samples were collected to evaluate potential contamination, as well as bias and variability of the data that may have resulted from sample collection, processing, storage, transportation, and laboratory analysis. QA/QC procedures and results are described in the appendix section titled "Quality-Assurance Methods."

\section{Quality-Control Results}

Results of QC analyses (blanks, replicates, and matrix and surrogate spikes) were used to evaluate the quality of the data for the groundwater samples. On the basis of detections in laboratory and field blanks collected for this and previous GAMA-PBP study units, the laboratory reporting levels (LRLs) for 4 VOCs and 11 inorganic constituents were raised in this report (Olsen and others, 2010; Fram and others, 2012). The GAMA Program refers to these raised reporting levels as "study reporting levels" (SRLs). Detections of the four VOCs with concentrations less than the raised reporting levels were reclassified as non-detections and not presented in this report. Detections of the 11 inorganic constituents with concentrations less than the SRL are flagged with a less than or equal to 
symbol ( $\leq$ ) in this report (see tables 5, 8, 9, A3 and additional discussion in the appendix section titled "Blanks") because the concentrations of these constituents could be less than or equal to the reported value.

Variability for 100 percent of the replicate pairs for constituents detected in samples was within the acceptable limits. Results from the replicates confirm that the procedures used to collect and analyze the samples did not introduce unacceptable levels of contamination or variability (see tables A4A-B and additional discussion in the appendix section titled "Replicates"). Median matrix-spike recoveries for 21 of the 172 organic and special-interest constituents analyzed were outside the acceptable range of between 70 and 130 percent. Constituents for which low recoveries occurred might not have been detected in some samples if they were present at concentrations near the LRLs, and constituents with high recoveries may indicate that reported values could be greater than what is in the sample (see tables 3B, 3D, A5B-C and additional discussion in the appendix section titled "Matrix Spikes").

\section{Comparison Benchmarks}

Concentrations of constituents detected in groundwater samples were compared with USEPA and CDPH regulatory and non-regulatory drinking-water health-based benchmarks and benchmarks established for aesthetic purposes (California Department of Public Health, 2008a, b; U.S. Environmental Protection Agency, 2008a, b). The chemical data presented in this report are meant to characterize the quality of the untreated groundwater within the primary aquifer system of the WSJV study unit and are not intended to represent the treated drinking water delivered to consumers by water purveyors. The chemical composition of treated drinking water may differ from untreated groundwater because treated drinking water may be subjected to disinfection, filtration, mixing with other waters, and (or) exposure to the atmosphere prior to its delivery to consumers. Comparisons of untreated groundwater to benchmarks are for illustrative purposes only and are not indicative of compliance or non-compliance with drinking-water regulations. The following benchmarks were used for comparisons:

\section{- MCL - M aximum Contaminant L evel. Legally} enforceable standards that apply to public-water systems and are designed to protect public health by limiting the levels of contaminants in drinking water. MCLs established by the USEPA are the minimum standards with which States are required to comply, and individual States may choose to set more stringent standards. CDPH has established MCLs for additional constituents not regulated by the USEPA, as well as lowered the benchmark concentrations for a number of constituents with MCLs established by the USEPA. In this report, a benchmark set by the USEPA and adopted by CDPH is labeled "MCL-US," and one set by CDPH that is more stringent than the MCL-US is labeled "MCL-CA." Well owners are notified when constituents are detected at concentrations greater than an MCL-US or an MCL-CA benchmark in samples collected for the GAMA-PBP, but these detections do not constitute violations of $\mathrm{CDPH}$ regulations.

- AL - Action L evel. Legally enforceable standards that apply to public-water systems and are designed to protect public health by limiting the levels of copper and lead in drinking water. Detections of copper or lead greater than the action-level benchmarks trigger requirements for mandatory water treatment to reduce the corrosiveness of water to water pipes. The action levels established by the USEPA and CDPH are the same; thus, these benchmarks are labeled "AL-US" in this report.

- SMCL - Secondary M aximum C ontaminant Level. Non-enforceable standards applied to constituents that affect the aesthetic qualities of drinking water, such as taste, odor, and color, or the technical qualities of drinking water, such as scaling and staining. Both the USEPA and CDPH define SMCLs, but unlike MCLs, SMCLs established by CDPH are not required to be at least as stringent as those established by USEPA. SMCLs established by CDPH are used in this report (SMCL-CA) for all constituents that have SMCL-CA values. The SMCL-US is used for $\mathrm{pH}$ because no SMCL-CA has been defined.

- NL-Notification Level. Health-based notification levels established by CDPH (NL-CA) for some of the constituents in drinking water that lack MCLs. If a constituent is detected in drinking water at concentrations greater than its NL-CA, California State law requires timely notification of local governing bodies and recommends consumer notification.

- HAL - L ifetime H ealth Advisory L evel. The maximum concentration of a constituent at which its presence in drinking water is not expected to cause any adverse carcinogenic effects for a lifetime of exposure. HALs are established by the USEPA (HAL-US) and are calculated assuming consumption of 2 liters (L) (2.1 quarts) of water per day over a 70 -year lifetime by a 70-kilogram (154-pound) adult and that 20 percent of a person's exposure comes from drinking water.

- RSD5-Risk-Specific Dose. The concentration of a constituent in drinking water corresponding to an excess estimated lifetime cancer risk of 1 in 100,000. RSD5 is an acronym for risk-specific dose at the $10^{-5}$ risk level $\left(10^{-5}\right.$ equals $\left.1 / 100,000\right)$. RSD5s are calculated by dividing the $10^{-4}$ cancer risk concentration established by the USEPA by 10 (RSD5-US). 
For constituents with MCLs, detections in groundwater samples were compared to the MCL-US or MCL-CA. Constituents with SMCLs were compared with the SMCL-CA. For chloride, sulfate, specific conductance, and total dissolved solids, CDPH defines a "recommended" and an "upper" SMCL-CA; detections of these constituents in groundwater samples were compared with both levels. The SMCL-US levels for these constituents correspond to their recommended SMCL-CAs. Detected concentrations of constituents without an MCL or SMCL were compared to the NL-CA. For constituents without an MCL, SMCL, or NL-CA, detected concentrations were compared with the HAL-US. For constituents without an MCL, SMCL, NL-CA, or HAL-US, detected concentrations were compared with the RSD5-US. For constituents without an MCL, SMCL, NL-CA, HAL-US, or RSD5-US, detected concentrations were compared with the AL-US. Note that using this hierarchy to select the comparison benchmark for a constituent with more than one type of established benchmark will not necessarily result in selection of the benchmark with the lowest concentration. For example, for zinc the SMCL-CA is 5,000 micrograms per liter $(\mu \mathrm{g} / \mathrm{L})$ and the HAL-US is $2,000 \mu \mathrm{g} / \mathrm{L}$, but the comparison benchmark selected by this hierarchy is the SMCL-CA. The comparison benchmarks used in this report are listed in table 3A-I for all constituents and in tables 4-13 for constituents detected in groundwater samples from the WSJV study unit. Not all constituents analyzed for this study have established benchmarks available. Detections of constituents at concentrations greater than the selected comparison benchmarks are marked with asterisk $(*)$ in tables 4,5 , and $\underline{8-11}$.

\section{Water-Quality Results}

\section{Groundwater-Quality Data}

Results from analyses of groundwater samples from the WSJV study unit are presented in tables 4-13. Groundwater samples collected in the WSJV study unit were analyzed for 245 constituents; 138 of those constituents were not detected in any of the samples, and 100 constituents were detected (tables 3A-I, 4).

For organic and special-interest constituent classes, the results tables (tables 5-7) include only constituents that were detected and the following summary statistics: the number of wells in which each constituent was detected, the frequency at which it was detected (in the study unit and in each study area), and the total number of constituents detected at each well. For the inorganic and isotopic constituent classes, the results tables (tables 8-13) include all of the wells, constituents, and samples analyzed.
Water-quality indicators measured in the field and at the NWQL are included in table 4. The results of groundwater analyses organized by compound classes are presented in tables 5-13:

- Organic constituents

- Volatile organic compounds and low-level fumigants (table 5)

- Pesticides and pesticide degradates (table 6)

- Constituents of special interest (table 7)

- Inorganic constituents

- Trace elements (table 8)

- Nutrients and dissolved organic carbon (table 9)

- Major and minor ions, silica, and total dissolved solids (table 10)

- Total arsenic and iron (unfiltered) and arsenic, chromium, and iron species (filtered) (table 11)

- Isotopic tracers (table 12)

- Dissolved standard gases (table 13)

\section{Water-Quality Indicators}

Measurements of turbidity, dissolved oxygen, $\mathrm{pH}$, specific conductance, alkalinity, and associated parameters (water temperature and bicarbonate and carbonate concentrations) are presented in table 4. Turbidity, dissolved oxygen, alkalinity, and bicarbonate and carbonate concentrations are used as indicators of natural processes that affect water chemistry. The $\mathrm{pH}$ value indicates the acidity of the water. Specific conductance is the measure of electrical conductivity of the water and is proportional to the amount of dissolved solids in the water.

Field $\mathrm{pH}$ values for 2 of the 39 grid wells sampled ( 1 in the DM study area and 1 in the WS study area) in the WSJV study unit exceeded the SMCL-US range for $\mathrm{pH}$ $(<6.5$ or $>8.5)$ (table 4). Low $\mathrm{pH}$ in water may contribute to corrosion of pipes, and high $\mathrm{pH}$ in water may contribute to scaling. Laboratory $\mathrm{pH}$ values may be dissimilar to field $\mathrm{pH}$ values because the $\mathrm{pH}$ of groundwater may change upon removal from the ambient environment and exposure to the atmosphere; therefore, the field measurements are preferred over the laboratory results.

Field specific-conductance values for 33 of the 39 grid wells sampled were greater than the recommended SMCL-CA of 900 microsiemens per centimeter at 25 degrees Celsius ( $\mu \mathrm{S} / \mathrm{cm}$ at $25^{\circ} \mathrm{C}$ ) (approximately 85 percent) (table 4). Field 
specific-conductance values for 25 of 29 grid wells sampled in the DM study area were greater than the recommended SMCL-CA, and 16 of these samples had field specificconductance values greater than the upper benchmark of $1,600 \mu \mathrm{S} / \mathrm{cm}$ at $25^{\circ} \mathrm{C}$. Field specific-conductance values for 8 of 10 grid wells sampled in the WS study area were greater than the recommended SMCL-CA, and 4 of these samples had values that were greater than the upper SMCL-CA.

Field specific-conductance values for 15 of the 19 understanding wells sampled (12 DM-U and 3 WS-U) were greater than the recommended SMCL-CA. Four DM-U well samples and $1 \mathrm{WS}-\mathrm{U}$ well sample had field specificconductance values greater than the upper SMCL-CA.

\section{Organic Constituents}

VOCs are present in paints, solvents, fuels, fuel additives, refrigerants, fumigants, and disinfected water and are characterized by their tendency to evaporate. VOCs generally persist longer in groundwater than in surface water because groundwater is isolated from the atmosphere.

Of the 85 VOCs analyzed in WSJV study unit, 22 were detected in groundwater samples; all concentrations in the grid wells sampled were less than health-based benchmarks. Benzene was detected at concentrations greater than the MCL-CA of $1 \mu \mathrm{g} / \mathrm{L}$ in samples from the three WS-U wells (table 5). One or more VOCs were detected in 13 of the 39 grid wells sampled (about 33 percent detection frequency; table 5). Chloroform (trichloromethane) was the only VOC detected in more than 10 percent of the grid wells in the WSJV study unit. Chloroform is among the most commonly detected VOCs in groundwater nationally (Zogorski and others, 2006).

VOCs were detected in 10 of the 29 grid wells sampled in the DM study area (approximately 34 percent). Chloroform was detected in more than 10 percent of the grid wells in the DM study area. VOCs were detected in 3 of the 10 grid wells sampled in the WS study area (30 percent). Chloroform and carbon disulfide were each detected in at least 10 percent of the grid wells in the WS study area. One or more VOCs were detected in nine understanding well samples (6 DM-U and 3 WS-U).

The low-level fumigants DBCP and EDB were sampled for at all 58 wells in the WSJV study unit. DBCP was detected in two grid wells sampled in the DM study area, whereas, EDB was not detected in any of the wells in the WSJV study unit (table 5).

Pesticides are chemicals used to control weeds, insects, fungi, and other pests in agricultural, urban, and suburban settings, and include herbicides, insecticides, and fungicides. Pesticide degradates are the product of the environmental transformations of the parent pesticide, and they can have similar properties to the parent pesticide. Of the 83 pesticides and pesticide degradates analyzed in the WSJV study unit, 16 were detected in groundwater samples; all concentrations were less than health-based benchmarks (table 6). One or more pesticide compounds were detected in 9 of the 39 grid wells sampled (about 23 percent detection frequency; table 6). Simazine and deethylatrazine (2-chloro-4-isopropylamino-6amino-s-triazine) were detected in more than 10 percent of the grid wells in the WSJV study unit.

Pesticides and pesticide degradates were detected in 9 of the 29 grid wells sampled in the DM study area (31 percent). Deethylatrazine, atrazine, hexazinone, and $S$-ethyldipropylthiocarbamate (EPTC) were detected in more than 10 percent of the grid wells in the DM study area. Simazine, deethylatrazine, and atrazine are among the nation's most commonly detected pesticide compounds in groundwater (Gilliom and others, 2006).

No pesticide and (or) pesticide degradate was detected in any of the 10 grid wells sampled in the WS study area. One or more pesticide compounds were detected in 11 of the understanding wells sampled (10 DM-U and $1 \mathrm{WS}-\mathrm{U}$ ).

\section{Constituents of Special Interest}

Perchlorate, NDMA, and 1,2,3-TCP are constituents of special interest in California because they may adversely affect water quality and recently have been detected in water supplies (California Department of Public Health, 2008b). Perchlorate and 1,2,3-TCP were analyzed for at all 58 wells, and NDMA was sampled for at the 33 slow wells in the WSJV study unit. NDMA was not detected in any of the grid or understanding wells; as a result, NDMA is not included in table 7.

In total, perchlorate was detected in 15 of 39 grid wells sampled (about 38 percent detection frequency; table 7). Perchlorate was detected in 13 of the 29 grid wells sampled in the DM study area (approximately 45 percent). Perchlorate was detected in 2 of the 10 grid wells sampled in the WS study area (20 percent). Perchlorate was not detected at concentrations greater than the MCL-CA of $6 \mu \mathrm{g} / \mathrm{L}$ in any of the grid or understanding wells sampled in the WSJV study unit. 1,2,3-TCP was detected in one DM-U well sample (table 7).

\section{Inorganic Constituents}

Unlike the organic constituents and the constituents of special interest, most of the inorganic constituents are naturally present in groundwater, although their concentrations may be influenced by human activities. Inorganic constituents were sampled for at all 58 wells in the WSJV study unit.

Health-based or non-health-based benchmarks have been established for 21 of 24 trace elements analyzed in this study (table 3E). Of the 17 trace elements with healthbased benchmarks, most detected concentrations in the wells sampled in the WSJV were less than established benchmarks. The exceptions were detections of arsenic, boron, molybdenum, selenium, strontium, and uranium (table 8). 
Arsenic concentrations greater than the MCL-US of $10 \mu \mathrm{g} / \mathrm{L}$ were detected in two grid wells sampled in the DM study area (table 8). Additionally, arsenic was measured at concentrations greater than the MCL-US in five of the understanding wells sampled (three DM-U and two WS-U).

Boron concentrations greater than the NL-CA of $1,000 \mu \mathrm{g} / \mathrm{L}$ were detected in 20 grid wells sampled (16 in the DM study area and 4 in the WS study area; table 8). Boron concentrations greater than the NL-CA were also detected in seven of the understanding wells sampled (six DM-U and one WS-U).

Molybdenum concentrations greater than the HAL-US of $40 \mu \mathrm{g} / \mathrm{L}$ were detected in two grid wells sampled in the DM study area (table 8). Additionally, molybdenum was measured at a concentration greater than the HAL-US in one DM-U well sample.

A selenium concentration greater than the MCL-US of $50 \mu \mathrm{g} / \mathrm{L}$ was detected in one grid well sampled in the DM study area (table 8). There were no detections of selenium greater than the MCL-US in the WS study area or in the WSJV understanding wells.

Strontium concentrations greater than the HAL-US of $4,000 \mu \mathrm{g} / \mathrm{L}$ were detected in two grid wells sampled in the DM study area (table 8). Additionally, strontium was measured at a concentration greater than the HAL-US in one DM-U well sample.

Uranium concentrations greater than the MCL-US of $30 \mu \mathrm{g} / \mathrm{L}$ were detected in two DM-U well samples (table 8). There were no detections of uranium greater than the MCL-US in the WSJV grid wells.

Nutrients (nitrogen and phosphorus) and DOC present in groundwater can affect biological activity in aquifers and in surface-water bodies that receive groundwater discharge. Inorganic nitrogen may be present in the form of ammonia, nitrite, or nitrate, depending on the oxidation-reduction state of the groundwater.

All concentrations of ammonia and nitrite measured in the WSJV study unit were less than health-based benchmarks. Concentrations of nitrate greater than the MCL-US of 10 milligrams per liter $(\mathrm{mg} / \mathrm{L})$ were detected in three grid wells sampled in the DM study area and in six DM-U well samples (table 9). There were no detections of nitrate greater than the MCL-US in grid wells sampled in the WS study area.

The CDPH has established non-health-based secondary benchmarks (SMCL-CAs) that are based on aesthetic properties (such as taste, color, and odor) and technical properties (such as scaling and staining) of water, rather than on human-health concerns for iron, manganese, silver, zinc, chloride, sulfate, and TDS.

Iron and manganese are trace elements whose concentrations are affected by the oxidation-reduction state of the groundwater. Iron concentrations greater than the SMCL-CA of $300 \mu \mathrm{g} / \mathrm{L}$ were detected in five grid wells sampled in the DM study area (table 8).
Manganese concentrations greater than the SMCL-CA of $50 \mu \mathrm{g} / \mathrm{L}$ were detected in 16 grid wells (13 in the DM study area and 3 in the WS study area; table 8). Additionally, manganese was measured at concentrations greater than the SMCL-CA in eight of the understanding wells sampled (six DM-U and two WS-U).

Chloride concentrations greater than the recommended SMCL-CA benchmark of $250 \mathrm{mg} / \mathrm{L}$ were detected in 14 grid wells sampled in the DM study area, and 5 of these detections were greater than the upper SMCL-CA benchmark of $500 \mathrm{mg} / \mathrm{L}$ (table 10). Chloride was not measured at concentrations greater than the recommended SMCL-CA benchmark in any of the grid wells sampled in the WS study area. Chloride was measured at concentrations greater than the recommended SMCL-CA in six of the understanding wells sampled (five DM-U and one WS-U).

Sulfate concentrations greater than the recommended SMCL-CA benchmark of $250 \mathrm{mg} / \mathrm{L}$ were detected in 21 WSJV grid wells (13 in the DM study area and 8 in the WS study area; table 10), and 13 of these detections (9 in the DM study area and 4 in the WS study area) were greater than the upper SMCL-CA benchmark of $500 \mathrm{mg} / \mathrm{L}$. Sulfate concentrations greater than the recommended SMCL-CA of $250 \mathrm{mg} / \mathrm{L}$ were detected in nine understanding wells sampled (eight DM-U and one WS-U), and four of these detections (three DM-U and one WS-U) were greater than the upper SMCL-CA.

TDS concentrations greater than the recommended SMCL-CA benchmark of $500 \mathrm{mg} / \mathrm{L}$ were detected in 36 WSJV grid wells sampled (27 in the DM study area and 9 in the WS study area; table 10), and 20 of these detections (16 in the DM study area and 4 in the WS study area) were greater than the upper SMCL-CA benchmark of 1,000 mg/L. TDS concentrations greater than the recommended SMCL-CA benchmark of $500 \mathrm{mg} / \mathrm{L}$ were detected in 15 of the understanding wells sampled (12 DM-U and $3 \mathrm{WS}-\mathrm{U})$, and 7 of these detections (6 DM-U and $1 \mathrm{WS}-\mathrm{U}$ ) were greater than the upper SMCL-CA.

Arsenic, chromium, and iron occur as different species, depending on the oxidation-reduction state of the groundwater. The oxidized and reduced species have different solubilities in groundwater, and the relative proportions of the oxidized and reduced species of each element can be used in the interpretation of the oxidation-reduction conditions of the aquifer.

Concentrations of total arsenic and total iron (unfiltered) and arsenic, chromium, and iron (filtered), and the dissolved concentration of either the reduced or the oxidized species of the element, are reported in table 11. Concentrations of total arsenic, total chromium, and total iron reported by the NWQL in table 8 are considered to be more accurate than the concentrations reported by the USGS National Research Program (NRP) Trace Metal Laboratory (TML), Boulder, Colorado, in table 11 (see the appendix section titled "Constituents Determined by Multiple Methods or Laboratories"). 


\section{Isotopic Tracers and Dissolved Gases}

The isotopic ratios, activities, and concentrations of many elements are used as tracers of hydrologic processes (Clark and Fritz, 1997). Stable isotope ratios of hydrogen and oxygen in water $\left(\delta^{2} \mathrm{H}\right.$ and $\left.\delta^{18} \mathrm{O}\right)$ aid in the interpretation of the sources of groundwater recharge. Stable isotopic ratios reflect the altitude, latitude, and temperature of precipitation and also the extent of evaporation of the water in surface-water bodies or soils prior to infiltration into the aquifer or directly from groundwater close to land surface once in the aquifer system. In the WSJV study unit, the stable isotope ratios of hydrogen in water ranged from -88.0 to -43.3 per mil, and oxygen in water ranged from -11.6 to -5.15 per mil (table 12).

Stable isotope ratios of nitrogen and oxygen in dissolved nitrate $\left(\delta^{15} \mathrm{~N}\right.$ and $\left.\delta^{18} \mathrm{O}\right)$ can be used to aid in interpretation of sources and processes affecting nitrate in aquifers. The stable isotopic ratios of nitrogen in dissolved nitrate ranged from 2.20 to 20.90 per mil, and oxygen in dissolved nitrate ranged from -0.41 to 15.97 per mil (table 12).

Stable isotope ratios of sulfur in dissolved sulfate $\left(\delta^{34} \mathrm{~S}\right)$ can be used to aid in the characterization of the groundwater system by determining the source of dissolved sulfur species and (or) aid in the understanding of chemical reactions occurring in groundwater systems, such as the microbial reduction of sulfate or the oxidation of sulfide. The stable isotope ratios of sulfur in dissolved sulfate ranged from -11.22 to 7.05 per mil (table 12 ).

Stable isotope ratios of boron in water $\left(\delta^{11} \mathrm{~B}\right)$ may be useful in distinguishing the sources of boron in groundwater. Natural sources include igneous rocks, evaporate minerals, seawater, and geothermal waters. Boron isotope variations have been shown to reflect mixing in the regional groundwater and the boron isotope fractionalization caused by boron removal by adsorption onto clays. As a result, boron isotopes are a useful tracer in groundwater systems in which the role of clay and minerals can be clearly identified (as a tracer for anthropogenic boron or as a tracer for seawater contamination, for example) (U.S. Geological Survey, 2004). The stable isotope ratios of boron in water ranged from 4.7 to $58.1 \mathrm{per}$ mil (table 12).

Isotopic ratios of strontium in water $\left({ }^{87} \mathrm{Sr} /{ }^{86} \mathrm{Sr}\right)$ reflect the amounts of strontium (and other inorganic constituents) the aquifer materials are contributing to the groundwater system. In regions that have diverse geology, strontium isotope ratios may aid in identifying groundwater-flow paths. The isotopic ratios of strontium ranged from 0.7047 to 0.7079 (table 12).

Tritium activities and helium isotope ratios provide information about the age (time since recharge) of groundwater. Tritium is a short-lived radioactive isotope of hydrogen that is incorporated into the water molecule. Low levels of tritium are produced continuously by interaction of cosmic radiation with the Earth's atmosphere, and a large amount of tritium was produced as a result of atmospheric testing of nuclear weapons between 1952 and 1963. Thus, concentrations of tritium greater than background levels generally indicate the presence of water recharged since the early 1950s. Helium isotope ratios can be used in conjunction with tritium concentrations to estimate ages for young groundwater. Of the isotopic tracer constituents analyzed for this study, tritium is the only one with a health-based benchmark. All measured tritium activities in samples from the wells in the WSJV study unit were more than three orders of magnitude less than the MCL-CA benchmark (table 12).

Carbon-14 is a radioactive isotope of carbon and an age-dating tracer. Low levels of carbon-14 are produced continuously by interaction of cosmic radiation with the Earth's atmosphere and are incorporated into atmospheric carbon dioxide. Carbon dioxide dissolves in precipitation, surface water, and groundwater exposed to the atmosphere, thereby entering the hydrologic cycle. Because carbon-14 decays with a half-life of approximately 5,700 years, low activities of carbon-14, relative to modern values, generally indicate a presence of groundwater that is several thousand years old or more. Carbon-14 activities ranged from 0.340 to 106.1 percent modern carbon, and the stable isotopes of carbon in dissolved inorganic carbon $\left(\delta^{13} \mathrm{C}\right)$ ranged from -37.47 to -6.03 per mil (table 12).

Gases dissolve in water that is in contact with the atmosphere, and the solubilities of the different gas species vary with temperature. Concentrations of dissolved standard and noble gases are used to estimate the conditions of groundwater recharge, particularly the temperature of the water at the time of recharge. Results for analyses of dissolved standard gases (methane, carbon dioxide, nitrogen, oxygen, and argon) are presented in table 13.

\section{Future Work}

Subsequent reports for the WSJV study unit will be focused on assessment of the data presented in this report by using statistical, qualitative, and quantitative approaches to evaluate the natural and human factors affecting groundwater quality in the WSJV study unit. Water-quality data contained in the CDPH databases will be used in combination with the data that are presented in this report. These subsequent reports will include the LLNL results (dissolved noble gas, tritium, and helium isotope ratios) for the WSJV study unit.

\section{Summary}

Groundwater quality in the approximately 2,170-squaremile Western San Joaquin Valley (WSJV) study unit was investigated by the U.S. Geological Survey (USGS) from March to July 2010, as part of the Priority Basin Project (PBP) of the California State Water Resources Control Board (SWRCB) Groundwater Ambient Monitoring and Assessment (GAMA) Program. The GAMA Program was created to provide a comprehensive baseline of groundwater 
quality in the State. The GAMA-PBP was created as a result of the Groundwater Quality Monitoring Act of 2001 (Sections 10780-10782.3 of the California Water Code, Assembly Bill 599) to assess and monitor the quality of groundwater. The GAMA-PBP is being conducted by the USGS in cooperation with the SWRCB and Lawrence Livermore National Laboratory (LLNL).

The GAMA WSJV study was designed to provide a spatially unbiased assessment of untreated-groundwater quality in the primary aquifer system and to facilitate statistically consistent comparisons of untreated-groundwater quality throughout California. The primary aquifer system is defined as parts of aquifers corresponding to the perforation intervals of wells listed in the California Department of Public Health (CDPH) database for the WSJV study unit. Groundwater quality in the primary aquifer system may differ from the quality in the shallower or deeper water-bearing zones; shallow groundwater may be more vulnerable to surficial contamination.

This study did not attempt to evaluate the quality of water delivered to consumers; after withdrawal from the ground, water typically is treated, disinfected, and blended with other waters to maintain acceptable water quality. The benchmarks used in this report apply to treated water that is served to the consumer, not to untreated groundwater. However, to provide some context for the results, concentrations of constituents measured in these groundwater samples were compared with benchmarks established by the U.S. Environmental Protection Agency (USEPA) and CDPH.

The WSJV study unit is located within the Central Valley hydrologic province and includes two groundwater subbasins defined by the California Department of Water Resources: Delta-Mendota and Westside. The WSJV study included assessment of the groundwater quality from 58 wells in Stanislaus, Merced, Madera, Fresno, and Kings Counties, California. Thirty-nine wells were selected using a randomized grid approach to achieve statistically unbiased representation of groundwater used for public drinking-water supplies (grid wells). Nineteen wells were selected to provide additional sampling density to aid in the understanding of aquifer-system flow and related groundwater-quality issues (understanding wells).

Groundwater samples were analyzed for water-quality indicators, organic constituents, constituents of special interest, and inorganic constituents. Isotopic tracers also were measured to provide a dataset that will be used to interpret the sources and ages of groundwater. In total, 245 constituents and 8 water-quality indicators were measured. This report describes the sampling, analytical, and quality-assurance methods used in the study and presents the results of the chemical analyses of the groundwater samples.

Quality-control samples (blanks, replicates, or matrix spikes) were collected at 16 percent of the wells in the WSJV study unit, and the results for these samples were used to evaluate the quality of the data for the groundwater samples. Blanks rarely contained detectable concentrations of any constituent. All replicate samples were within acceptable limits of variability, and matrix-spike recoveries were generally within the acceptable range.

Organic and inorganic constituents were sampled at all 58 wells in the WSJV study unit. Most detections were measured at concentrations less than health-based benchmarks.

In the Delta-Mendota subbasin study area grid wells, 2 detections of arsenic were greater than the USEPA maximum contaminant level (MCL-US), 16 detections of boron were greater than the CDPH notification level (NLCA), 2 detections of molybdenum were greater than the USEPA lifetime health advisory level (HAL-US), 1 detection of selenium was greater than the MCL-US, 2 detections of strontium were greater than the HAL-US, and 3 detections of nitrate were greater than the MCL-US. In the Westside subbasin study area grid wells, four detections of boron were at concentrations greater than the NL-CA.

In the WSJV study unit understanding wells, three detections of benzene were greater than the $\mathrm{CDPH}$ maximum contaminant level (MCL-CA), five detections arsenic were greater than the MCL-US, seven detections of boron were greater than the NL-CA, one detection of molybdenum was greater than the HAL-US, one detection of strontium was greater than the HAL-US, two detections of uranium were greater than the MCL-US, and six detections of nitrate were greater than the MCL-US.

In the Delta-Mendota subbasin study area grid wells, 5 detections of iron were greater than the CDPH secondary maximum contaminant level (SMCL-CA), 13 detections of manganese were greater than the SMCL-CA, 14 detections of chloride were greater than the recommended SMCL-CA ( 5 of the detections were greater than the upper SMCL-CA), 13 detections of sulfate were greater than the SMCL-CA ( 9 of the detections were greater than the upper SMCL-CA), and 27 detections of TDS were greater than the recommended SMCL-CA (16 of the detections were greater than the upper SMCL-CA).

In the Westside subbasin study area grid wells, three detections of manganese were greater than the SMCL-CA, eight detections of sulfate were greater than the SMCL-CA (four of the detections were greater than the upper SMCL-CA), and nine detections of TDS were greater than the recommended SMCL-CA (four of the detections were greater than the upper SMCL-CA).

In the WSJV study unit understanding wells, 8 detections of manganese were greater than the SMCL-CA, 6 detections of chloride were greater than the recommended SMCL-CA, 9 detections of sulfate were greater than the SMCL-CA ( 4 of the detections were greater than the upper SMCL-CA), and 15 detections of TDS were greater than the recommended SMCL-CA (7 of the detections were greater than the upper SMCL-CA). 


\section{Acknowledgments}

The authors thank the following cooperators for their support: the California State Water Resources Control Board, California Department of Public Health, California Department of Water Resources, and Lawrence Livermore National Laboratory. We especially thank the well owners and water purveyors for allowing the U.S. Geological Survey to collect samples from their wells.

\section{References Cited}

American Public Health Association, 1998, Standard methods for the examination of water and wastewater (20th ed.): Washington, D.C., American Public Health Association, American Water Works Association, and Water Environment Federation, p. 3-37-3-43.

Anderson, R.L., 1987, Practical statistics for analytical chemists: New York, Van Nostrand Reinhold Company, Inc., $315 \mathrm{p}$.

Ball, J.W., and McCleskey, R.B., 2003a, A new cationexchange method for accurate field speciation of hexavalent chromium: U.S. Geological Survey Water-Resources Investigations Report 03-4018, 17 p.

Ball, J.W., and McCleskey, R.B., 2003b, A new cationexchange method for accurate field speciation of hexavalent chromium: Talanta, v. 61, p. 305-313.

Belitz, Kenneth, Dubrovsky, N.M., Burow, K.R., Jurgens, Bryant, and Johnson, Tyler, 2003, Framework for a groundwater quality monitoring and assessment program for California: U.S. Geological Survey Water-Resources Investigations Report 03-4166, 78 p.

Belitz, Kenneth, and Heimes, F.J., 1990, Character and evolution of the ground-water flow system in the central part of the western San Joaquin Valley, California: U.S. Geological Survey Water-Supply Paper 2348, 28 p.

Bennett, P.A., Bennett, G.L., V, and Belitz, Kenneth, 2009, Groundwater quality data for the Northern Sacramento Valley, 2007-Results from the California GAMA Program: U.S. Geological Survey Data Series 452, 90 p.

Brenton, R.W., and Arnett, T.L., 1993, Methods of analysis by the U.S. Geological Survey National Water Quality Laboratory-Determination of dissolved organic carbon by UV-promoted persulfate oxidation and infrared spectrometry: U.S. Geological Survey Open-File Report 92-480, $12 \mathrm{p}$.
Bullen, T.D., Krabbenhoft, D.P., and Kendall, Carol, 1996, Kinetic and mineralogic controls on the evolution of groundwater chemistry and ${ }^{87} \mathrm{Sr} /{ }^{86} \mathrm{Sr}$ in a sandy silicate aquifer, northern Wisconsin, USA: Geochimica et Cosmochimica Acta, v. 60, no. 10, p. 1807-1821.

Burton, C.A., and Belitz, Kenneth, 2008, Groundwater quality data in the Southeast San Joaquin Valley, 20052006 - Results from the California GAMA Program: U.S. Geological Survey Data Series 351, 103 p.

Busenberg, Eurybiades, Plummer, L.N., and Bartholomay, R.C., 2001, Estimated age and source of the young fraction of ground water at the Idaho National Engineering and Environmental Laboratory: U.S. Geological Survey Water-Resources Investigations Report 01-4265, 144 p.

California Department of Public Health, 2008a, California drinking water-related laws-Drinking water-related regulations, Title 22: California Department of Public Health, accessed January 6, 2010, at http://www.CDPH. ca.gov/certlic/drinkingwater/Pages/Lawbook.aspx.

California Department of Public Health, 2008b, Drinking water notification levels-Notification levels: California Department of Public Health, accessed January 6, 2010, at http://www.CDPH.ca.gov/certlic/drinkingwater/Pages/ NotificationLevels.aspx.

California Department of Water Resources, 2003, California's groundwater update 2003: California Department of Water Resources Bulletin 118, 246 p., accessed January 25, 2010, at http://www.water.ca.gov/groundwater/ bulletin118/update2003.cfm.

California Department of Water Resources, 2006a, California's groundwater-Individual basin descriptions, San Joaquin Valley Groundwater Basin, Delta-Mendota Subbasin: California Department of Water Resources Bulletin 118, accessed January 25, 2010, at http://www.water.ca.gov/ pubs/groundwater/bulletin_118/basindescriptions/5-22.07. pdf.

California Department of Water Resources, 2006b, California's groundwater-Individual basin descriptions, San Joaquin Valley Groundwater Basin, Westside Subbasin: California Department of Water Resources Bulletin 118, accessed January 25, 2010, at http://www.water.ca.gov/ pubs/groundwater/bulletin_118/basindescriptions/5-22.09. pdf.

California Environmental Protection Agency, 2011, GAMAGroundwater Ambient Monitoring and Assessment Program: State Water Resources Control Board website, accessed February 14, 2011, at http://www.waterboards. ca.gov/water_issues/programs/gama/. 
California State Water Resources Control Board, 2003, Report to the Governor and Legislature-A comprehensive groundwater quality monitoring program for California: Assembly Bill 599, March 2003, 121 p., accessed January 11, 2011, at http://www.waterboards.ca.gov/gama/ docs/final ab $599 \mathrm{rpt}$ to legis 731 03.pdf.

California State Water Resources Control Board, 2009, Geotracker GAMA: State Water Resources Control Board database, accessed February 14, 2011, at https://geotracker.waterboards.ca.gov/gama/.

Carmody, R.W., Plummer, L.N., Busenburg, E., and Coplen, T.B., 1998, Methods for collection of dissolved sulfate and sulfide and analysis of their sulfur isotopic composition: U.S. Geological Survey Open-File Report 97-234, 101 p.

Childress, C.J.O., Foreman, W.T., Connor, B.F., and Maloney, T.J., 1999, New reporting procedures based on long-term method detection levels and some considerations for interpretations of water-quality data provided by the U.S. Geological Survey National Water Quality Laboratory: U.S. Geological Survey Open-File Report 99-193, 19 p.

Clark, I.D., and Fritz, P., 1997, Environmental isotopes in hydrogeology: Boca Raton, Fla., CRC Press LLC, 328 p.

Connor, B.F., Rose, D.L., Noriega, M.C., Murtagh, L.K., and Abney, S.R., 1998, Methods of analysis by the U.S. Geological Survey National Water Quality Laboratory-Determination of 86 volatile organic compounds in water by gas chromatography/mass spectrometry, including detections less than reporting limits: U.S. Geological Survey Open-File Report 97-829, 78 p.

Coplen, T.B., 1994, Reporting of stable hydrogen, carbon, and oxygen isotopic abundances: Pure and Applied Chemistry, v. 66 , p. 273-276.

Coplen, T.B., Hopple, J.A., Bohlke, J.K., Peiser, H.S., Rieder, S.E., Krouse, H.R., Rosman, K.J.R., Ding, T., Vocke, R.D., Jr., Revesz, K.M., Lamberty, A., Taylor, P., and DeBierve, P., 2002, Compilation of minimum and maximum isotope ratios of selected elements in naturally occurring terrestrial materials and reagents: U.S. Geological Survey Water-Resources Investigations Report 01-4222, $98 \mathrm{p}$.

Coplen, T.B., Wildman, J.D., and Chen, J., 1991, Improvements in the gaseous hydrogen-water equilibrium technique for hydrogen isotope analysis: Analytical Chemistry, v. 63, p. 910-912.

Davis, G.H., Green, J.H., Olmsted, F.H., and Brown, D.W., 1959, Groundwater conditions and storage capacity in the San Joaquin Valley, California: U.S. Geological Survey Water-Supply Paper 1469, 277 p.
Densmore, J.N., Fram, M.S., and Belitz, Kenneth, 2009, Ground-water quality data in the Owens and Indian Wells Valleys study unit, 2006-Results from the California GAMA Program: U.S. Geological Survey Data Series 427, $86 \mathrm{p}$.

Donahue, D.J., Linick, T.W., and Jull, A.J.T., 1990, Isotoperatio and background corrections for accelerator mass spectrometry radiocarbon measurements: Radiocarbon, v. 32, book 2, p. 135-142.

Dwyer, G.S., and Vengosh, A., 2008, Alternative filament loading solution for accurate analysis of boron isotopes by negative thermal ionization mass spectrometry: Eos, Transactions, American Geophysical Union, v. 89, no. 53, abstract H51C-0824.

Eaton, G.F., Hudson, G.B., and Moran, J.E., 2004, Tritiumhelium-3 age-dating of groundwater in the Livermore Valley of California: American Chemical Society ACS Symposium Series, v. 868, p. 235-245.

Eichelberger, J.W., 1993, U.S. Environmental Protection Agency Method 504.1, 1,2-dibromoethane (EDB), 1,2-dibromo-3-chloropropane (DBCP), and 1,2,3-trichloropropane (1,2,3-TCP) in water by microextraction and gas chromatograph revision 1.1Methods for determination of organic chemicals in drinking water, supplement III.

Epstein, Samuel, and Mayeda, T.K., 1953, Variation of O-18 content of water from natural sources: Geochimica et Cosmochimica Acta, v. 4, p. 213-224.

Faires, L.M., 1993, Methods of analysis by the U.S. Geological Survey National Water Quality Laboratory-Determination of metals in water by inductively coupled plasma-mass spectrometry: U.S. Geological Survey Open-File Report 92-634, 28 p.

Farrar, J.W., and Long, H.K., 1997, Report on the U.S. Geological Survey's evaluation program for standard reference samples distributed in September 1996-T-143 (trace constituents), T-145 (trace constituents), M-140 (major constituents), N-51 (nutrient constituents), P-27 (low ionic strength constituents), and $\mathrm{Hg}-23$ (mercury): U.S. Geological Survey Open-File Report 97-20, 145 p.

Faunt, C.C., ed., 2009, Groundwater availability of the Central Valley aquifer, California: U.S. Geological Survey Professional Paper 1766, 225 p.

Firestone, R.B., Shirley, V.S., Baglin, C.M., Chu, S.Y.F., and Zipkin, J., 1996, Table of isotopes (8th ed.): New York, John Wiley \& Sons, 3168 p., accessed March 16, 2011, at http://ie.lbl.gov/toipdf/toi20.pdf. 
Fishman, M.J., 1993, Methods of analysis by the U.S. Geological Survey National Water Quality Laboratory-Determination of inorganic and organic constituents in water and fluvial sediments: U.S. Geological Survey Open-File Report 93-125, 217 p.

Fishman, M.J., and Friedman, L.C., 1989, Methods for determination of inorganic substances in water and fluvial sediments: U.S. Geological Survey Techniques of WaterResources Investigations, book 5, chap. A1, 545 p.

Fram, M.S., Olsen, L.D., and Belitz, Kenneth, 2012, Evaluation of volatile organic compound (VOC) blank data and application of study reporting levels to groundwater data collected for the California GAMA Priority Basin Project, May 2004 through September 2010: U.S. Geological Survey Scientific Investigations Report 2012-5139, 94 p.

Gagnon, A.R., and Jones, G.A., 1993, AMS-graphite target production methods at the Woods Hole Oceanographic Institution during 1986-1991: Radiocarbon, v. 35, book 2, p. 301-310.

Garbarino, J.R., 1999, Methods of analysis by the U.S. Geological Survey National Water Quality Laboratory-Determination of dissolved arsenic, boron, lithium, selenium, strontium, thallium, and vanadium using inductively coupled plasma-mass spectrometry: U.S. Geological Survey Open-File Report 99-093, 31 p.

Garbarino, J.R., Kanagy, J.R., and Cree, M.E., 2006, Determination of elements in natural-water, biota, sediment, and soil samples using collision/reaction cell inductively coupled plasma-mass spectrometry: U.S. Geological Survey Techniques and Methods, book 5, chap. B1, 88 p.

Gilliom, R.J., Barbash, J.E., Crawford, C.G., Hamilton, P.A., Martin, J.D., Nakagaki, N., Nowell, L.H., Scott, J.C., Stackelberg, P.E., Thelin, G.P., and Wolock, D.M., 2006, The quality of our Nation's waters-Pesticides in the Nation's streams and ground water, 1992-2001: U.S. Geological Survey Circular 1291, 172 p.

Gran, G., 1952, Determination of the equivalence point in potentiometric titration, Part II: Analyst, v. 77, p. 661.

Grob, R.L., ed., 1995, Modern practice of gas chromatography (3d ed.): New York, John Wiley \& Sons, 888 p.

Hahn, G.J., and Meeker, W.Q., 1991, Statistical intervals-A guide for practitioners: New York, John Wiley \& Sons, $392 \mathrm{p}$.

Hem, J.D., 1985, Study and interpretation of the chemical characteristics of natural water: U.S. Geological Survey Water-Supply Paper 2254, 263 p., 3 pls.
Hoaglin, D.C., 1983, Letter values-A set of selected order statistics, in Hoaglin, D.C., Mosteller, F., and Tukey, J.W., eds., Understanding robust and exploratory data analysis: New York, John Wiley \& Sons, p. 33-54.

Hotchkiss, W.R., and Balding, G.O., 1971, Geology, hydrology, and water quality of the Tracy-Dos Palos Area San Joaquin Valley, California: U.S. Geological Survey Open-File Report 71-169, 107 p.

Kenny, J.F., Barber, N.L., Hutson, S.S., Linsey, K.S., Lovelace, J.K., and Maupin, M.A., 2009, Estimated use of water in the United States in 2005: U.S. Geological Survey Circular 1344, $52 \mathrm{p}$.

Koterba, M.T., Wilde, F.D., and Lapham, W.W., 1995, Groundwater data-collection protocols and procedures for the National Water-Quality Assessment ProgramCollection and documentation of water-quality samples and related data: U.S. Geological Survey Open-File Report 95-399, 113 p.

Kulongoski, J.T., and Belitz, Kenneth, 2004, GroundWater Ambient Monitoring and Assessment Program: U.S. Geological Survey Fact Sheet 2004-3088, 2 p.

Landon, M.K., Belitz, Kenneth, Jurgens, B.C., Kulongoski, J.T., and Johnson, T.D., 2010, Status and understanding of groundwater quality in the CentralEastside San Joaquin Basin, 2006: California GAMA Priority Basin Project: U.S. Geological Survey Scientific Investigations Report 2009-5266, 97 p.

Lane, S.L., Flanagan, Sarah, and Wilde, F.D., 2003, Selection of equipment for water sampling (ver. 2.0): U.S. Geological Survey Techniques of Water-Resources Investigations, book 9, chap. A2, accessed March 18, 2011, at http://pubs.water.usgs.gov/twri9A2/.

Lewis, M.E., 2006, Dissolved oxygen (ver. 2.1):

U.S. Geological Survey Techniques of Water-Resources Investigations, book 9, chap. A6.2, accessed March 18, 2011, at http://pubs.water.usgs.gov/twri9A6.2/.

Lindley, C.E., Stewart, J.T., and Sandstrom, M.W., 1996, Determination of low concentrations of acetochlor in water by automated solid-phase extraction and gas chromatography with mass selective detection: Journal of AOAC International, v. 79, no. 4, p. 962-966.

Madsen, J.E., Sandstrom, M.W., and Zaugg, S.D., 2003, Methods of analysis by the U.S. Geological Survey National Water Quality Laboratory-A method supplement for the determination of fipronil and degradates in water by gas chromatography/mass spectrometry: U.S. Geological Survey Open-File Report 02-462, 11 p. 
Maloney, T.J., ed., 2005, Quality management system, U.S. Geological Survey National Water Quality Laboratory: U.S. Geological Survey Open-File Report 2005-1263, accessed March 8, 2011, at http://pubs.usgs.gov/of/2005/1263/.

McCleskey, R.B., Nordstrom, D.K., and Ball, J.W., 2003, Metal interferences and their removal prior to the determination of $\mathrm{As}(\mathrm{T})$ and $\mathrm{As}(\mathrm{III})$ in acid mine waters by hydride generation atomic absorption spectrometry: U.S. Geological Survey Water-Resources Investigations Report 03-4117, 14 p.

McCurdy, D.E., Garbarino, J.R., and Mullin, A.H., 2008, Interpreting and reporting radiological water-quality data: U.S. Geological Survey Techniques and Methods, book 5, chap. B6, 33 p.

McLain, B., 1993, Methods of analysis by the U.S. Geological Survey National Water Quality Laboratory-Determination of chromium in water by graphite furnace atomic absorption spectrophotometry: U.S. Geological Survey Open-File Report 93-449, $16 \mathrm{p}$.

McNichol, A.P., Gagnon, A.R. Jones, G.A., and Osborne, E.A., 1992, Illumination of a black box-Analysis of gas composition during graphite target preparation, in Long, A., and Kra, R.S., eds., Proceedings of the 14th International ${ }^{14} \mathrm{C}$ Conference: Radiocarbon, v. 34, book 3, p. 321-329.

McNichol, A.P., Jones, G.A., Hutton, D.L., and Gagnon, A.R., 1994, The rapid preparation of seawater $\sum \mathrm{CO}_{2}$ for radiocarbon analysis at the National Ocean Sciences AMS Facility: Radiocarbon, v. 36, book 2, p. 237-246.

Moran, J.E., Hudson, G.B., Eaton, G.F., and Leif, R., 2002, A contamination vulnerability assessment for the Livermore-Amador and Niles Cone Groundwater Basins: Lawrence Livermore National Laboratory internal report UCRL-AR-148831, 25 p.

Mueller, D.K., and Titus, C.J., 2005, Quality of nutrient data from streams and ground water sampled during water years 1992-2001: U.S. Geological Survey Scientific Investigations Report 2005-5106, 27 p.

Okamoto, H.S., Steeber, W.R., Remoy, R., Hill, P., and Perera, S.K., eds., 2002, Determination of 1,2,3-trichloropropane in drinking water by purge and trap gas chromatography/mass spectrometry (February 2002): California Department of Health Services, Division of Drinking Water and Environmental Management, Sanitation and Radiation Laboratories Branch, accessed February 4, 2011, at http://www.cdph.ca.gov/certlic/ drinkingwater/Documents/Drinkingwaterlabs/TCPbyPTGCMS.pdf.
Olsen, L.D., Fram, M.S., and Belitz, Kenneth, 2010, Review of trace-element field-blank data collected for the California Groundwater Ambient Monitoring and Assessment (GAMA) Program, May 2004-January 2008: U.S. Geological Survey Scientific Investigations Report 2009-5220, 47 p.

Patton, C.J., and Kryskalla, J.R., 2003, Methods of analysis by the U.S. Geological Survey National Water Quality Laboratory-Evaluation of alkaline persulfate digestion as an alternative to Kjeldahl digestion for determination of total and dissolved nitrogen and phosphorous in water: U.S. Geological Survey Water-Resources Investigations Report 03-4174, $33 \mathrm{p}$.

Pirkey, K.D., and Glodt, S.R., 1998, Quality control at the U.S. Geological Survey National Water Quality Laboratory: U.S. Geological Survey Fact Sheet 026-98, 4 p., accessed February 3, 2011, at http://pubs.er.usgs.gov/usgspubs/fs/ fs 02698 .

Planer-Friedrich, B., London, J., McCleskey, R.B., Nordstrom, D.K., and Wallschlager, D., 2007, Thioarsenates in geothermal waters of Yellowstone National ParkDetermination, preservation, and geochemical importance: Environmental Science \& Technology, v. 41, p. 5245-5251.

Plomley, J.B., Koester, C.J., and March, R.E., 1994, Determination of NDMA in complex environmental matrices by quadrupole ion storage tandem mass spectrometry enhanced by unidirectional ion ejection: Analytical Chemistry, v. 66, no. 24, p. 4437-4443.

PRISM Climate Group, Oregon State University, 2010, United States average annual precipitation, maximum and minimum temperature, 1971-2009, accessed January 14, 2011, at http://prism.oregonstate.edu/.

Radtke, D.B., Davis, J.V., and Wilde, F.D., 2005, Specific electrical conductance (ver. 1.2): U.S. Geological Survey Techniques of Water-Resources Investigations, book 9, chap. A6.3, accessed January 17, 2011, at http://pubs.water.usgs.gov/twri9A6.3/.

Révész, K., and Casciotti, K., 2007, Determination of the $\delta\left({ }^{15} \mathrm{~N} /{ }^{14} \mathrm{~N}\right)$ and $\delta\left({ }^{18} \mathrm{O} /{ }^{16} \mathrm{O}\right)$ of nitrate in water-RSIL Lab Code 2900, chap. C17, in Révész, Kinga, and Coplen, T.B., eds., Methods of the Reston Stable Isotope Laboratory: Reston, Virginia, U.S. Geological Survey Techniques and Methods, book 10, sec. C, chap. 17, 24 p.

Sandstrom, M.W., Stroppel, M.E., Foreman, W.T., and Schroeder, M.P., 2001, Methods of analysis by the U.S. Geological Survey National Water Quality Laboratory-Determination of moderate-use pesticides and selected degradates in water by $\mathrm{C}-18$ solid-phase extraction and gas chromatography/mass spectrometry: U.S. Geological Survey Water-Resources Investigations Report 01-4098, 70 p. 
Saucedo, G.J., Bedford, D.R., Raines, G.L., Miller, R.J., and Wentworth, C.M., 2000, GIS data for the geologic map of California (version 2.0): Sacramento, Calif., California Department of Conservation, Division of Mines and Geology.

Schmitt, S.J., Milby Dawson, B.J., and Belitz, Kenneth, 2009, Groundwater-quality data in the Antelope Valley study unit, 2008-Results from the California GAMA Program: U.S. Geological Survey Data Series 479, 79 p.

Schneider, R.J., Jones, G.A., McNichol, A.P., von Reden, K.F., Elder, K.A., Huang, K., and Kessel, E.D., 1994, Methods for data screening, flagging, and error analysis at the National Ocean Sciences AMS Facility: Nuclear Instruments and Methods in Physics Research, book 92, p. $172-175$.

Scott, J.C., 1990, Computerized stratified random site selection approaches for design of a groundwater quality sampling network: U.S. Geological Survey Water-Resources Investigations Report 90-4101, 109 p.

Shelton, J.L., Burow, K.R., Belitz, Kenneth, Dubrovsky, N.M., Land, M.T., and Gronberg, J.M., 2001, Low-level volatile organic compounds in active public supply wells as groundwater tracers in the Los Angeles physiographic basin, California, 2000: U.S. Geological Survey Water-Resources Investigations Report 01-4188, 29 p.

State of California, 2001a, Assembly Bill No. 599, Chapter 522, accessed February 14, 2011, at http://www.swrcb.ca.gov/gama/docs/ab_599 bill_20011005_chaptered.pdf.

State of California, 2001b, Groundwater Monitoring Act of 2001: California Water Code, part 2.76, Sections 1078010782.3, accessed February 14, 2011, at http://www.leginfo.ca.gov/cgi-bin/displaycode?section=wat \&group $=10001-11000 \&$ file $=10780-10782.3$.

Stookey, L.L., 1970, FerroZine-A new spectrophotometric reagent for iron: Analytical Chemistry, v. 42, p. 779-781.

Thatcher, L.L., Janzer, V.J., and Edwards, K.W., 1977, Methods for the determination of radioactive substances in water: U.S. Geological Survey Techniques of WaterResources Investigations, book 5, chap. A5, 95 p.

Timme, P.J., 1995, National Water Quality Laboratory 1995 services catalog: U.S. Geological Survey Open-File Report 95-352, 120 p.

To, T.B., Nordstrom, D.K., Cunningham, K.M., Ball, J.W., and McCleskey, R.B., 1998, New method for the direct determination of dissolved $\mathrm{Fe}(\mathrm{III})$ concentration in acid mine waters: Environmental Science \& Technology, v. 33, p. $807-813$.
U.S. Census Bureau, 2011, State and county quick facts, California, accessed February 25, 2011, at http://quickfacts.census.gov/qfd/states/06/0644028.html.

U.S. Department of Commerce, National Climatic Data Center, 2011, National Climatic Data Center, accessed January 13, 2011, at http://www.ncdc.noaa.gov/oa/ncdc. $\underline{\mathrm{html}}$.

U.S. Environmental Protection Agency, 1989, Semivolatile organic compounds by isotope dilution GSMS (July 1989): Washington, D.C., U.S. Environmental Protection Agency, $68 \mathrm{p}$.

U.S. Environmental Protection Agency, 2002, Guidelines for establishing procedures for the analysis of pollutants: U.S. Code of Federal Regulations, Title 40, 136 p.

U.S. Environmental Protection Agency, 2005, Method 331.0 Determination of perchlorate in drinking water by liquid chromatography electrospray ionization mass spectrometry (Revision 1.0, January 2005): Office of Groundwater and Drinking Water, EPA Document \#815-R-05-007, 34 p., accessed January 11, 2011, at http://www.epa.gov/ safewater/methods/pdfs/methods/met331 0.pdf.

U.S. Environmental Protection Agency, 2008a, Drinking water contaminants, accessed January 11, 2011, at http://www.epa.gov/safewater/contaminants/index.html.

U.S. Environmental Protection Agency, 2008b, Drinking water health advisories - 2006 drinking water standards and health advisory tables, accessed January 11, 2011, at http://www.epa.gov/waterscience/criteria/drinking/.

U.S. Geological Survey, 2004, Resources on isotopesPeriodic table-Boron: U.S. Geological Survey Isotopic Tracers Project, accessed March 2, 2011, at http://wwwrcamnl.wr.usgs.gov/isoig/period/b iig.html.

U.S. Geological Survey, 2010, Inorganic blind sample project, accessed January 14, 2011, at http://bqs.usgs.gov/ibsp/ qadata.shtml.

U.S. Geological Survey, 2011a, What is the Priority Basin Project?, accessed February 14, 2011, at http://ca.water. usgs.gov/gama/.

U.S. Geological Survey, 2011b, Publications, accessed February 14, 2011, at http://ca.water.usgs.gov/gama/ includes/GAMA_publications.html.

U.S. Geological Survey, [variously dated], National field manual for the collection of water-quality data: U.S. Geological Survey Techniques of Water-Resources Investigations, book 9, chap. A1-A9, accessed January 17, 2011, at http://water.usgs.gov/owq/ FieldManual/. 
Vengosh A., Chivas A.R., and McCulloch M.T., 1989, Direct determination of boron and chlorine isotopes in geological materials by negative thermal ionization mass spectrometry: Chemical Geology, v. 79, p. 333-343.

Vogel, J.S., Nelson, D.E., and Southon, J.R., 1987, ${ }^{14} \mathrm{C}$ background levels in an accelerator mass spectrometry system: Radiocarbon, v. 29, book 3, p. 323-333.

Water Education Foundation, 2006, Where does my water come from?: Sacramento, Calif., Water Education Foundation, accessed January 13, 2011, at http://www.water-ed.org/watersources/default.asp.

Weiss, R.F., 1968, Piggyback sampler for dissolved gas studies on sealed water samples: Deep Sea Research, v. 15, p. 721-735.

Western Regional Climate Center, 2011, Western Regional Climate Center, Summary climate data for Southern California, average monthly precipitation data, accessed January 10, 2011, at http://www.wrcc.dri.edu/summary/ Climsmsca.html.

Wilde, F.D., ed., 2004, Cleaning of equipment for water sampling (ver. 2.0): U.S. Geological Survey Techniques of Water-Resources Investigations, book 9, chap. A3, accessed February 8, 2011, at http://pubs.water.usgs.gov/twri9A3/.

Wilde, F.D., 2006, Temperature (ver. 2): U.S. Geological Survey Techniques of Water-Resources Investigations, book 9, chap. A6.1, accessed February 8, 2011, at http://pubs.water.usgs.gov/twri9A6.1/.

Wilde, F.D., Busenberg, E., and Radtke, D.B., 2006, pH (ver. 1.3): U.S. Geological Survey Techniques of WaterResources Investigations, book 9, chap. A6.4, accessed February 8, 2011, at http://pubs.water.usgs.gov/twri9A6.4/.

Wilde, F.D., and Radtke, D.B., 2005, General information and guidelines (ver. 1.2): U.S. Geological Survey Techniques of Water-Resources Investigations, book 9, chap. A6.0, accessed February 8, 2011, at http://pubs.water.usgs.gov/ twri9A6.0/.
Wilde, F.D., Radtke, D.B., Gibs, J., and Iwatsubo, R.T., 1999, Collection of water samples: U.S. Geological Survey Techniques of Water-Resources Investigations, book 9, chap. A4, accessed February 8, 2011, at http://pubs. water. usgs.gov/twri9A4/.

Wilde, F.D., Radtke, D.B., Gibs, J., and Iwatsubo, R.T., 2004, Processing of water samples: U.S. Geological Survey Techniques of Water-Resources Investigations, book 9 , chap. A5, accessed February 8, 2011, at http://pubs.water. usgs.gov/twri9A5/.

Worthington, C.E., Sebastian, J.E., Gilmore, D.F., and Benfield, R.C., 2007, Investigative report of carbon disulfide contamination in powder-free latex exam gloves, in Tennessee Department of Environment \& Conservation, Department of Energy Oversight Division, Environmental Monitoring Report, January through December 2006, p. 233-236.

Wright, M.T., Belitz, Kenneth, and Burton, C.A., 2005, California GAMA Program - Groundwater quality in the San Diego drainages hydrologic province, California, 2004: U.S. Geological Survey Data Series 129, 91 p.

Zaugg, S.D., Sandstrom, M.W., Smith, S.G., and Fehlberg, K.M., 1995, Methods of analysis by the U.S. Geological Survey National Water Quality Laboratory-Determination of pesticides in water by $\mathrm{C}-18$ solid-phase extraction and capillary-column gas chromatography/mass spectrometry: U.S. Geological Survey Open-File Report 95-181, 60 p.

Zogorski, J.S., Carter, J.M., Ivahnenko, T., Lapham, W.W., Moran, M.J., Rowe, B.L., Squillace, P.J., and Toccalino, P.L., 2006, Volatile organic compounds in the Nation's ground water and drinking-water supply wells: U.S. Geological Survey Circular 1292, 101 p. 
Table 1. Identification, sampling, and construction information for wells sampled for the Western San Joaquin Valley (WSJV) Groundwater Ambient Monitoring and Assessment (GAMA) study unit, California, March to July 2010.

[Sampling schedule is described in table 2. Land-surface datum (LSD) is a datum plane that is approximately at land surface at each well. The altitude of the LSD is described in feet above the North American Vertical Datum of 1988 (NAVD 88). GAMA well identification number: DM, Delta-Mendota subbasin study area grid well; DM-U, Delta-Mendota subbasin study area understanding well; WS, Westside subbasin study area grid well; WS-U, Westside subbasin study area understanding well. Other abbreviations: ft, feet; na, not available]

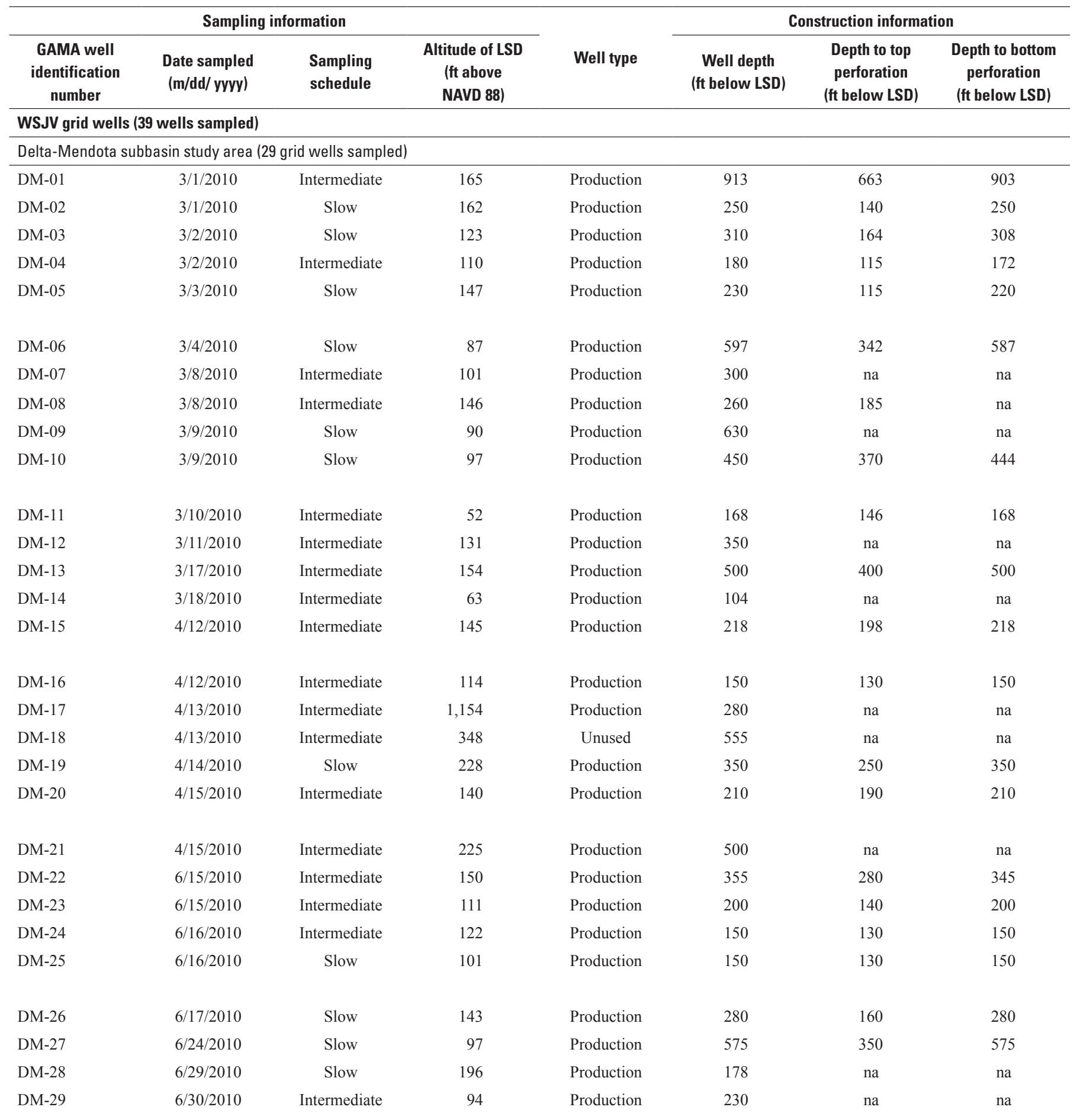


Table 1. Identification, sampling, and construction information for wells sampled for the Western San Joaquin Valley (WSJV) Groundwater Ambient Monitoring and Assessment (GAMA) study unit, California, March to July 2010.—Continued

[Sampling schedule is described in table 2. Land-surface datum (LSD) is a datum plane that is approximately at land surface at each well. The altitude of the LSD is described in feet above the North American Vertical Datum of 1988 (NAVD 88). GAMA well identification number: DM, Delta-Mendota subbasin study area grid well; DM-U, Delta-Mendota subbasin study area understanding well; WS, Westside subbasin study area grid well; WS-U, Westside subbasin study area understanding well. Other abbreviations: $\mathrm{ft}$, feet; na, not available]

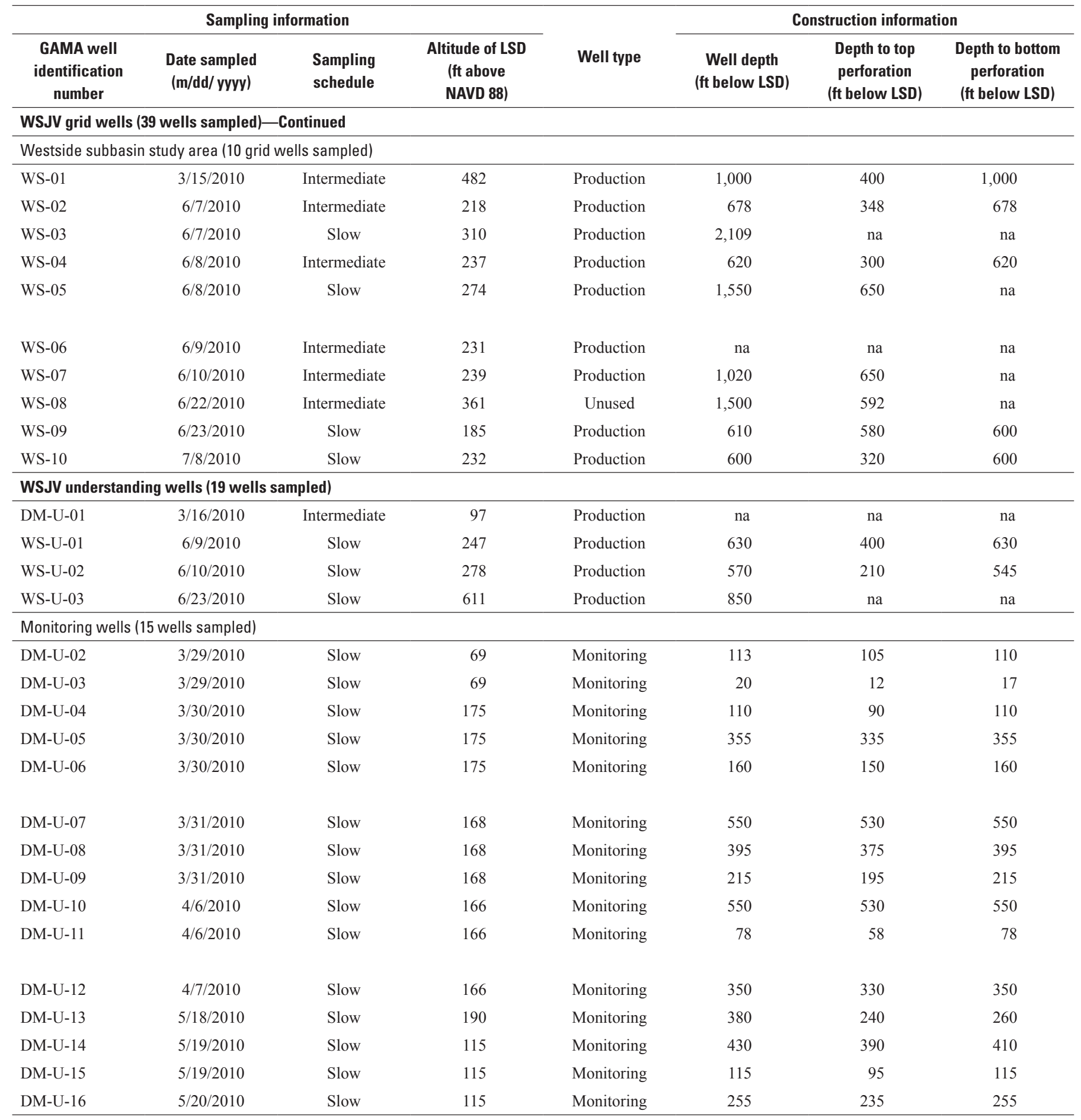


Table 2. Classes of chemical constituents and water-quality indicators collected for the slow and the intermediate well-sampling schedules in the Western San Joaquin Valley (WSJV) Groundwater Ambient Monitoring and Assessment (GAMA) study unit, California, March to July 2010.

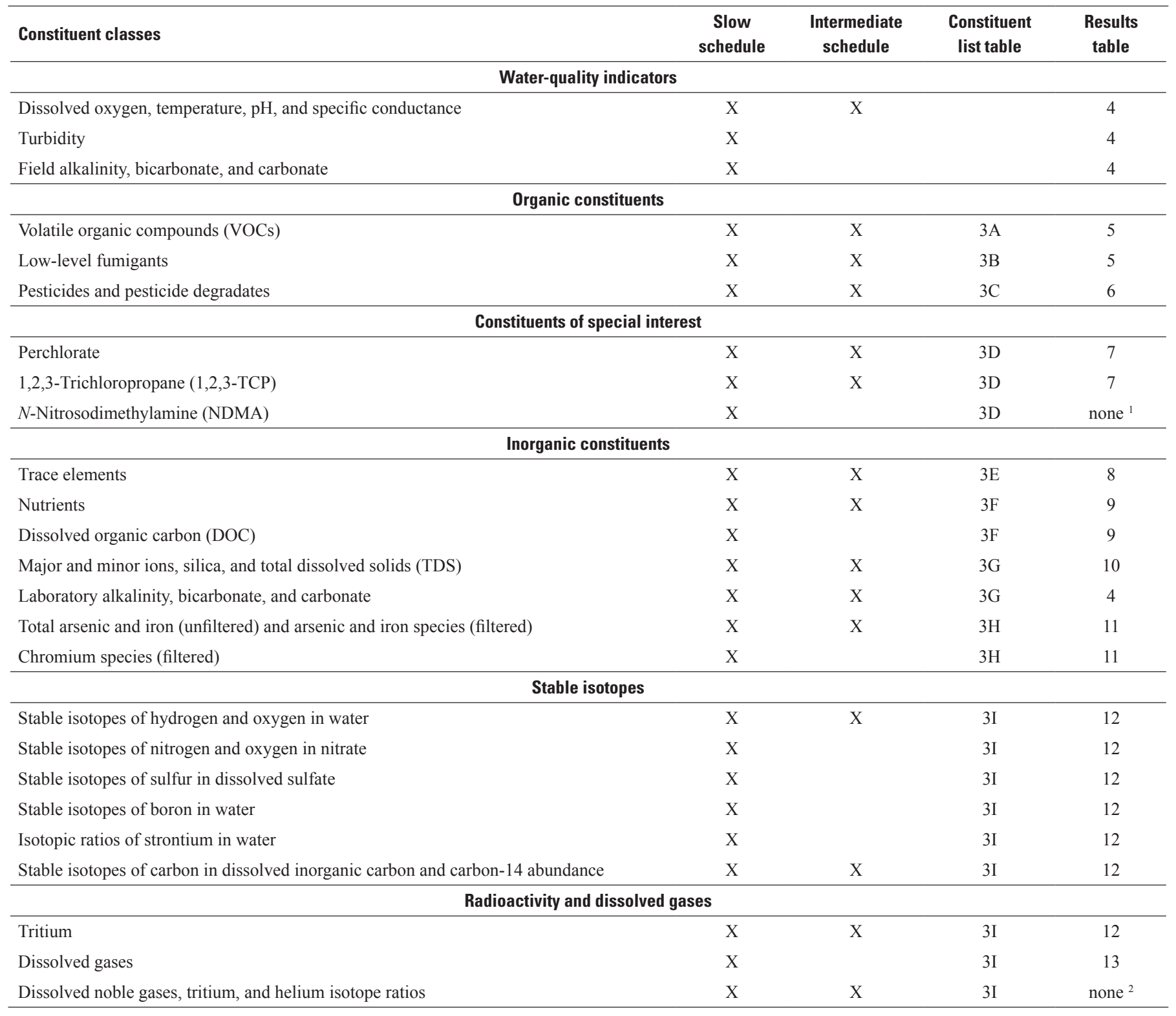

\footnotetext{
${ }^{1}$ Constituent not detected in groundwater samples.

${ }^{2}$ Results for dissolved noble gases, tritium, and helium isotope ratios analyzed by Lawrence Livermore National Laboratory (LLNL), Livermore, California, were not completed in time for inclusion in this report; results will be presented in a subsequent publication.
} 


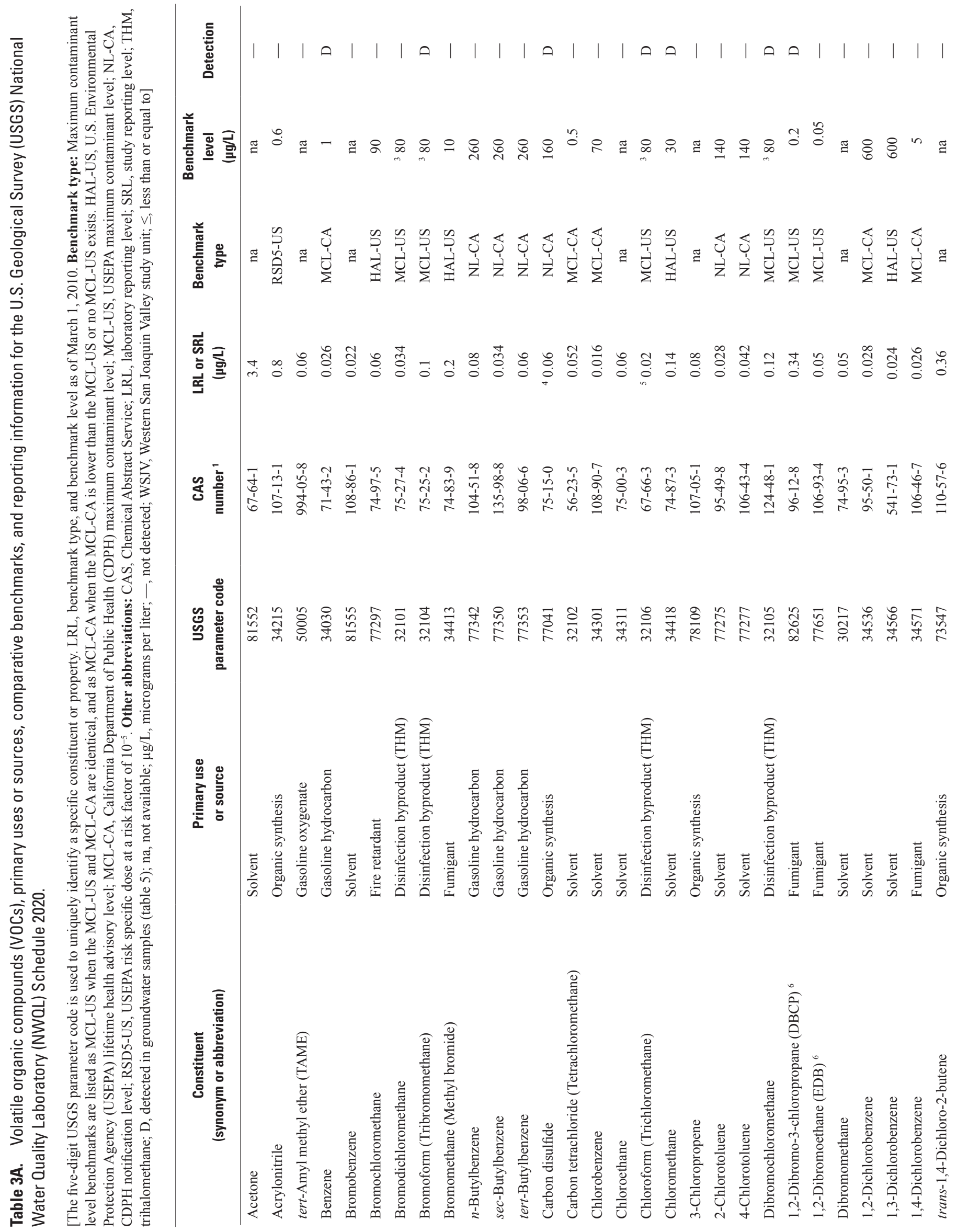




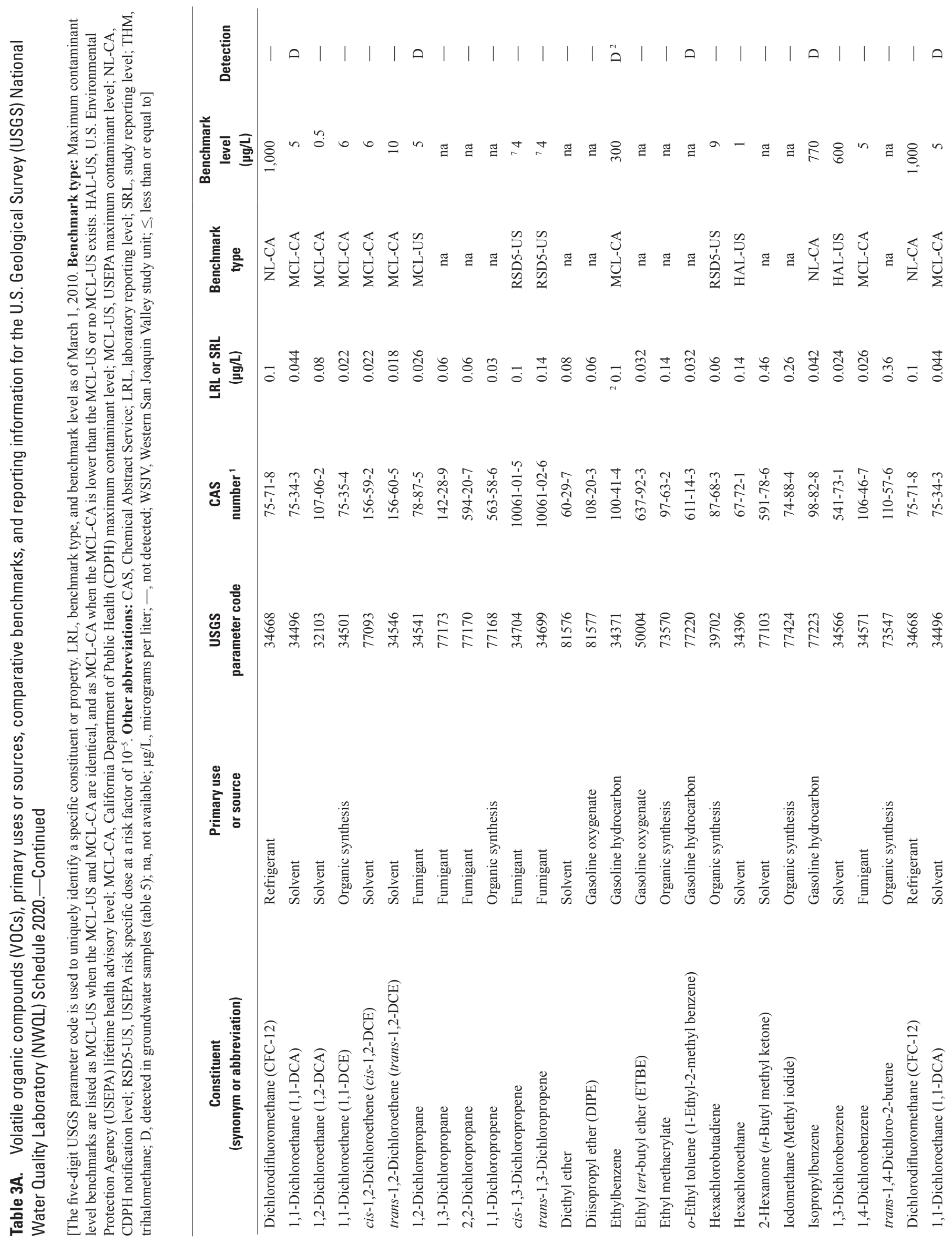




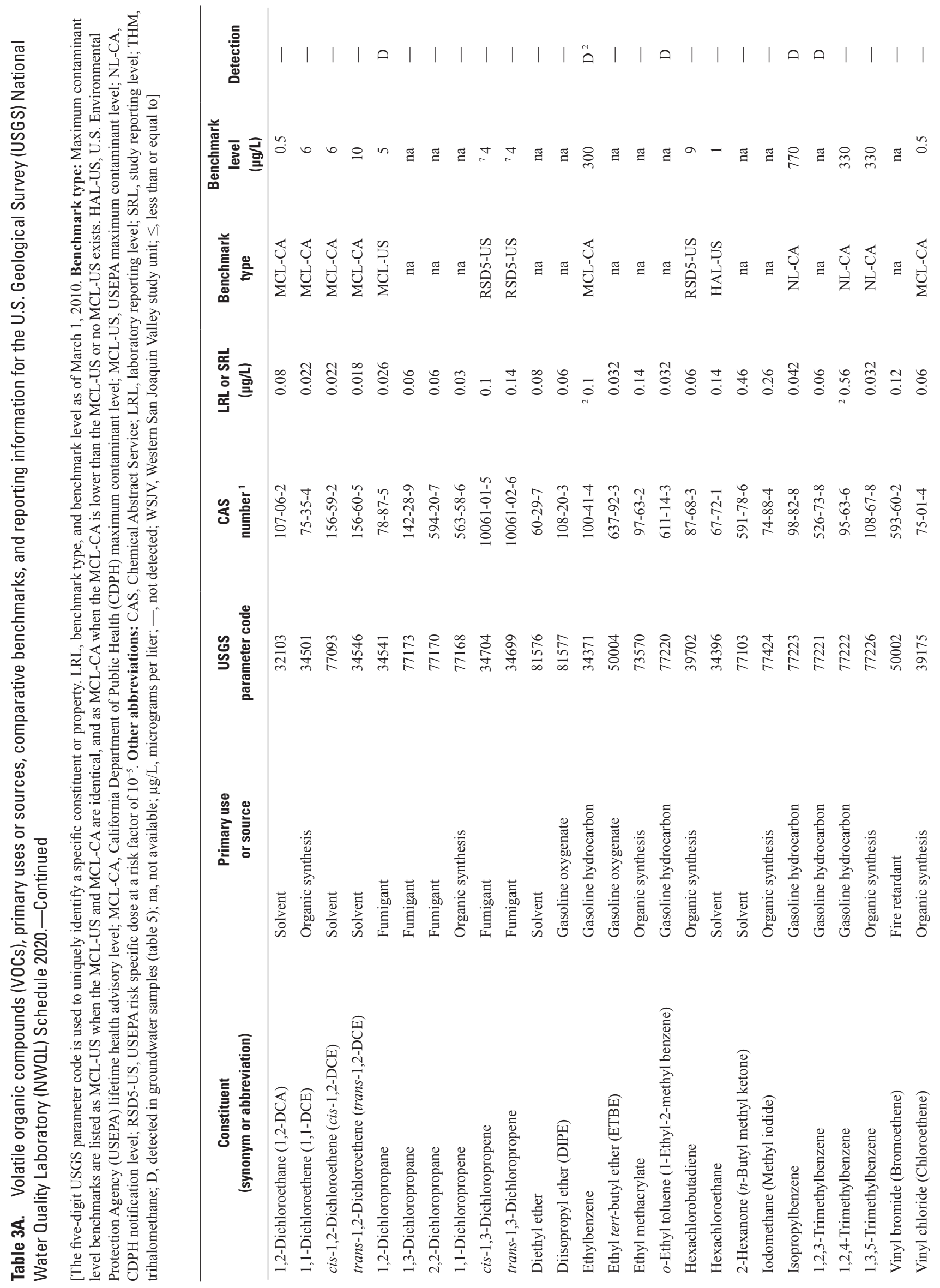




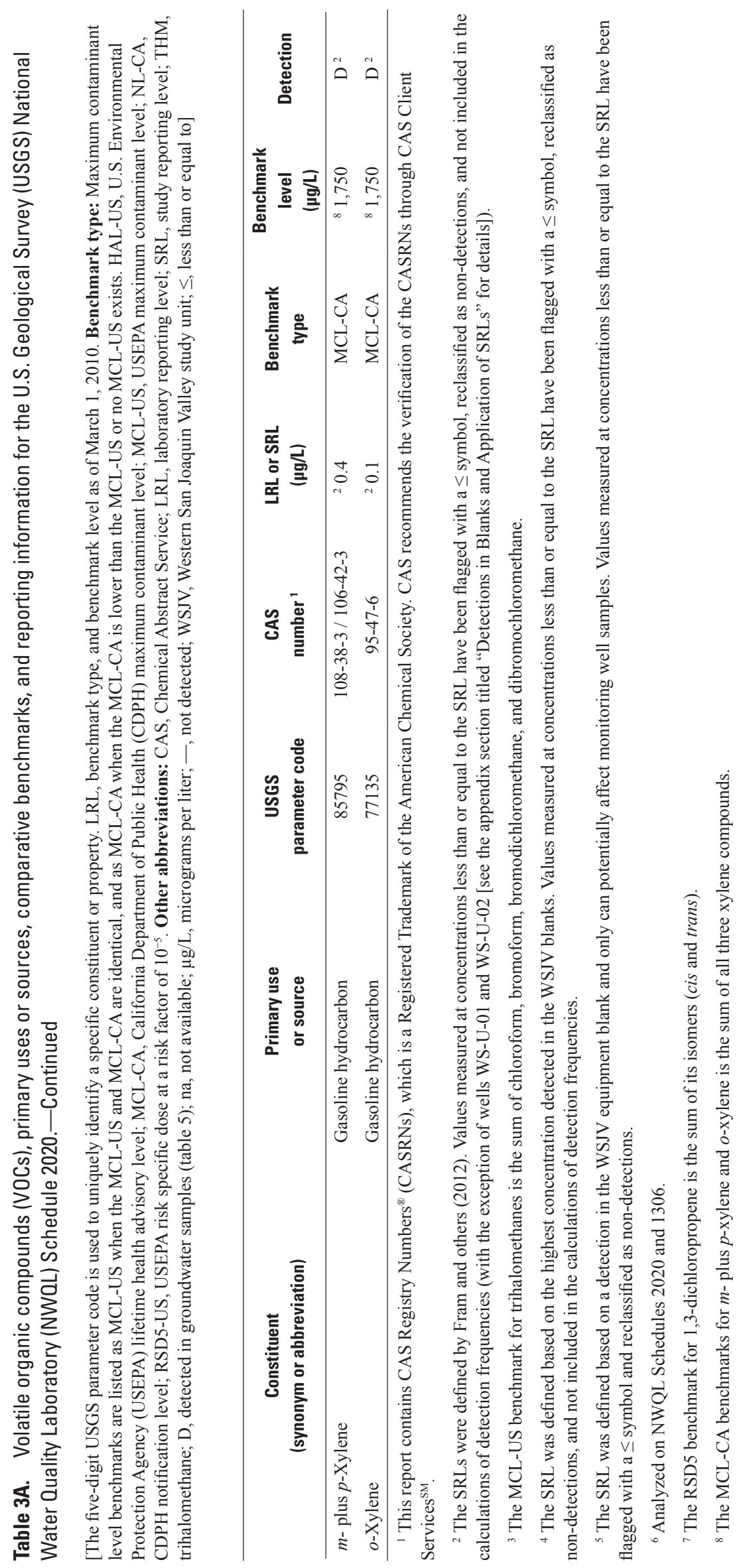




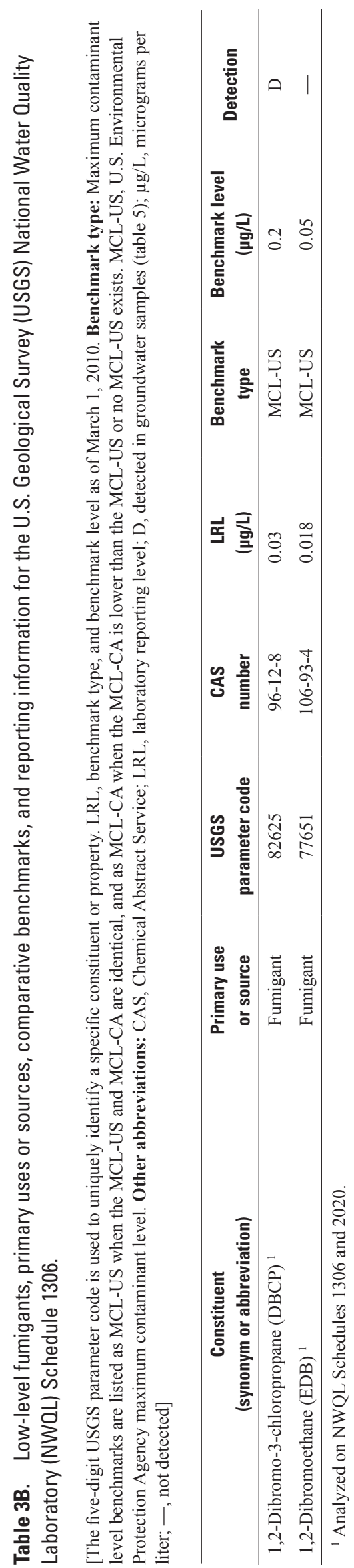


Table 3C. Pesticides and pesticide degradates, primary uses or sources, comparative benchmarks, and reporting information for the U.S. Geological Survey (USGS) National Water Quality Laboratory (NWQL) Schedule 2033.

[The five-digit USGS parameter code is used to uniquely identify a specific constituent or property. LRL, benchmark type, and benchmark level as of March 1, 2010. Benchmark type: Maximum contaminant level benchmarks are listed as MCL-US when the MCL-US and MCL-CA are identical, and as MCL-CA when the MCL-CA is lower than the MCL-US or no MCL-US exists. HAL-US, U.S. Environmental Protection Agency (USEPA) lifetime health advisory level; MCL-CA, California Department of Public Health maximum contaminant level; MCL-US, USEPA maximum contaminant level; RSD5-US, USEPA risk specific dose at a risk factor of $10^{-5}$; Other abbreviations: CAS, Chemical Abstract Service; LRL, laboratory reporting level; D, detected in groundwater samples (table 6); na, not available; $\mu \mathrm{g} / \mathrm{L}$, micrograms per liter; - , not detected]

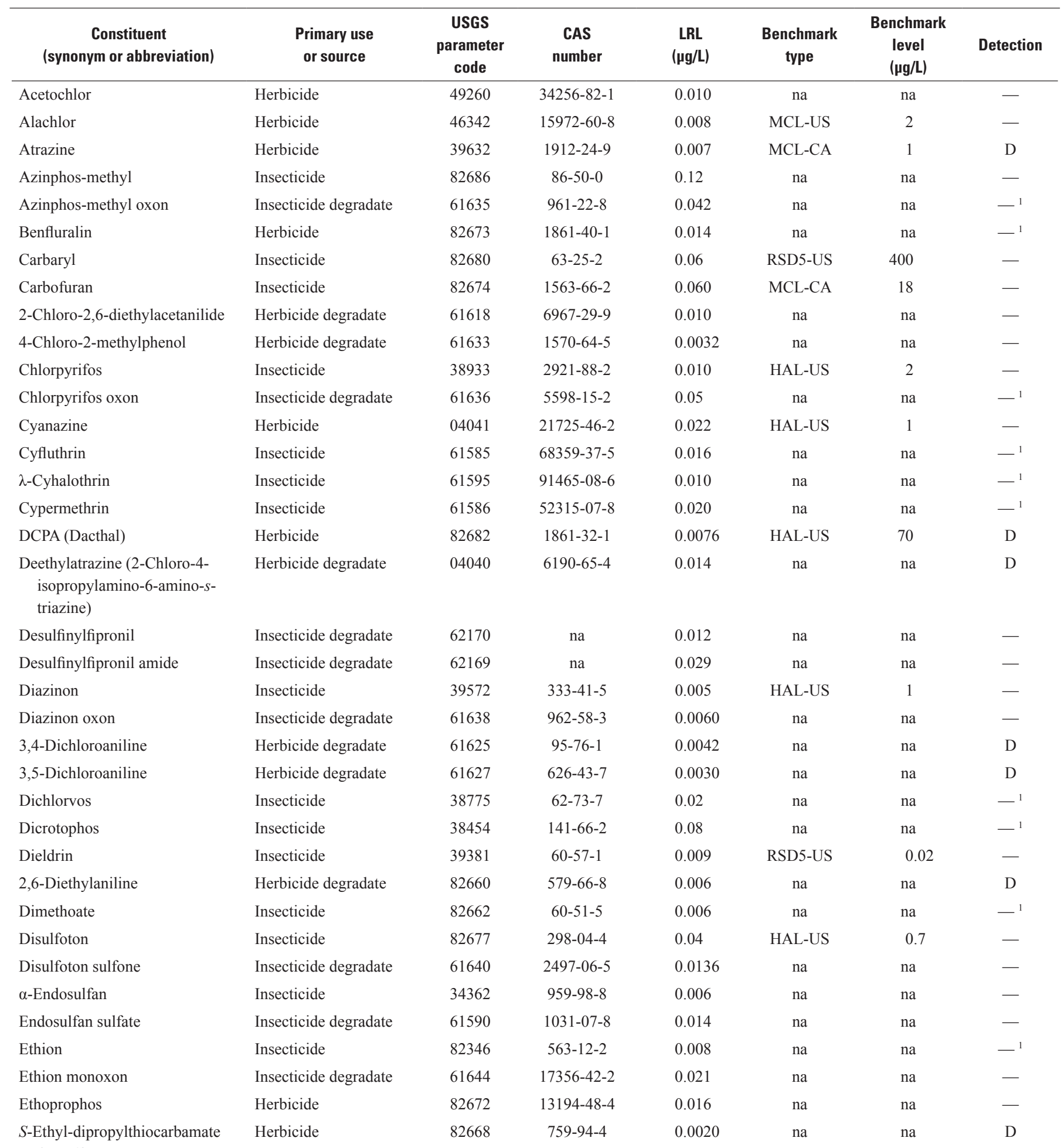

(EPTC) 
Table 3C. Pesticides and pesticide degradates, primary uses or sources, comparative benchmarks, and reporting information for the U.S. Geological Survey (USGS) National Water Quality Laboratory (NWOL) Schedule 2033.—Continued

[The five-digit USGS parameter code is used to uniquely identify a specific constituent or property. LRL, benchmark type, and benchmark level as of March 1, 2010. Benchmark type: Maximum contaminant level benchmarks are listed as MCL-US when the MCL-US and MCL-CA are identical, and as MCL-CA when the MCL-CA is lower than the MCL-US or no MCL-US exists. HAL-US, U.S. Environmental Protection Agency (USEPA) lifetime health advisory level; MCL-CA, California Department of Public Health maximum contaminant level; MCL-US, USEPA maximum contaminant level; RSD5-US, USEPA risk specific dose at a risk factor of $10^{-5}$; Other abbreviations: CAS, Chemical Abstract Service; LRL, laboratory reporting level; D, detected in groundwater samples (table 6); na, not available; $\mu \mathrm{g} / \mathrm{L}$, micrograms per liter; —, not detected]

\begin{tabular}{|c|c|c|c|c|c|c|c|}
\hline $\begin{array}{c}\text { Constituent } \\
\text { (synonym or abbreviation) }\end{array}$ & $\begin{array}{l}\text { Primary use } \\
\text { or source }\end{array}$ & $\begin{array}{c}\text { USGS } \\
\text { parameter } \\
\text { code }\end{array}$ & $\begin{array}{c}\text { CAS } \\
\text { number }\end{array}$ & $\begin{array}{c}\text { LRL } \\
(\mu \mathrm{g} / \mathrm{L})\end{array}$ & $\begin{array}{l}\text { Benchmark } \\
\text { type }\end{array}$ & $\begin{array}{c}\text { Benchmark } \\
\text { level } \\
(\mu \mathrm{g} / \mathrm{L})\end{array}$ & Detection \\
\hline 2-Ethyl-6-methylaniline & Herbicide degradate & 61620 & $24549-06-2$ & 0.0098 & na & na & $\mathrm{D}$ \\
\hline Fenamiphos & Insecticide & 61591 & $22224-92-6$ & 0.030 & HAL-US & 0.7 & - \\
\hline Fenamiphos sulfone & Insecticide degradate & 61645 & $31972-44-8$ & 0.053 & na & na & - \\
\hline Fenamiphos sulfoxide & Insecticide degradate & 61646 & $31972-43-7$ & 0.08 & na & na & -1 \\
\hline Fipronil sulfide & Insecticide degradate & 62167 & $120067-83-6$ & 0.013 & na & na & - \\
\hline Fipronil sulfone & Insecticide degradate & 62168 & $120068-36-2$ & 0.024 & na & na & - \\
\hline Fonofos & Insecticide & 04095 & $944-22-9$ & 0.0044 & HAL-US & 10 & - \\
\hline Hexazinone & Herbicide & 04025 & $51235-04-2$ & 0.008 & HAL-US & 400 & $\mathrm{D}^{1}$ \\
\hline Iprodione & Fungicide & 61593 & $36734-19-7$ & 0.014 & na & na & - \\
\hline Metalaxyl & Fungicide & 61596 & $57837-19-1$ & 0.007 & na & na & $\mathrm{D}$ \\
\hline Methidathion & Insecticide & 61598 & $950-37-8$ & 0.006 & na & na & - \\
\hline Metolachlor & Herbicide & 39415 & $51218-45-2$ & 0.014 & HAL-US & 700 & $\mathrm{D}$ \\
\hline Metribuzin & Herbicide & 82630 & 21087-64-9 & 0.012 & HAL-US & 70 & - \\
\hline Molinate & Herbicide & 82671 & $2212-67-1$ & 0.002 & MCL-CA & 20 & $\mathrm{D}$ \\
\hline Myclobutanil & Fungicide & 61599 & $88671-89-0$ & 0.010 & na & na & - \\
\hline 1-Naphthol & Insecticide degradate & 49295 & $90-15-3$ & 0.036 & na & na & -1 \\
\hline Oxyfluorfen & Herbicide & 61600 & $42874-03-3$ & 0.010 & na & na & -1 \\
\hline Paraoxon-methyl & Insecticide degradate & 61664 & $950-35-6$ & 0.010 & na & na & -1 \\
\hline Phosmet oxon & Insecticide degradate & 61668 & $3735-33-9$ & 0.0511 & na & na & -1 \\
\hline Prometon & Herbicide & 04037 & $1610-18-0$ & 0.012 & HAL-US & 100 & $\mathrm{D}$ \\
\hline Prometryn & Herbicide & 04036 & $7287-19-6$ & 0.006 & na & na & $\mathrm{D}$ \\
\hline Pronamide & Herbicide & 82676 & $23950-58-5$ & 0.0036 & RSD5-US & 20 & - \\
\hline Propanil & Herbicide & 82679 & 709-98-8 & 0.010 & na & na & - \\
\hline Propargite & Insecticide & 82685 & $2312-35-8$ & 0.020 & na & na & -1 \\
\hline cis-Propiconazole & Fungicide & 79846 & $60207-90-1$ & 0.006 & na & na & -2 \\
\hline trans-Propiconazole & Fungicide & 79847 & $60207-90-1$ & 0.02 & na & na & - \\
\hline Simazine & Herbicide & 04035 & $122-34-9$ & 0.006 & MCL-US & 4 & $\mathrm{D}$ \\
\hline Tebuconazole & Fungicide & 62852 & $107534-96-3$ & 0.020 & na & na & - \\
\hline Tebuthiuron & Herbicide & 82670 & $34014-18-1$ & 0.028 & HAL-US & 500 & $\mathrm{D}^{2}$ \\
\hline
\end{tabular}


Table 3C. Pesticides and pesticide degradates, primary uses or sources, comparative benchmarks, and reporting information for the U.S. Geological Survey (USGS) National Water Quality Laboratory (NWOL) Schedule 2033.—Continued

[The five-digit USGS parameter code is used to uniquely identify a specific constituent or property. LRL, benchmark type, and benchmark level as of March 1, 2010. Benchmark type: Maximum contaminant level benchmarks are listed as MCL-US when the MCL-US and MCL-CA are identical, and as MCL-CA when the MCL-CA is lower than the MCL-US or no MCL-US exists. HAL-US, U.S. Environmental Protection Agency (USEPA) lifetime health advisory level; MCL-CA, California Department of Public Health maximum contaminant level; MCL-US, USEPA maximum contaminant level; RSD5-US, USEPA risk specific dose at a risk factor of $10^{-5}$; Other abbreviations: CAS, Chemical Abstract Service; LRL, laboratory reporting level; D, detected in groundwater samples (table 6); na, not available; $\mu \mathrm{g} / \mathrm{L}$, micrograms per liter; —, not detected]

\begin{tabular}{|c|c|c|c|c|c|c|c|}
\hline $\begin{array}{c}\text { Constituent } \\
\text { (synonym or abbreviation) }\end{array}$ & $\begin{array}{l}\text { Primary use } \\
\text { or source }\end{array}$ & $\begin{array}{c}\text { USGS } \\
\text { parameter } \\
\text { code }\end{array}$ & $\begin{array}{c}\text { CAS } \\
\text { number }\end{array}$ & $\begin{array}{c}\text { LRL } \\
(\mu \mathrm{g} / \mathrm{L})\end{array}$ & $\begin{array}{l}\text { Benchmark } \\
\text { type }\end{array}$ & $\begin{array}{c}\text { Benchmark } \\
\text { level } \\
(\mu \mathrm{g} / \mathrm{L})\end{array}$ & Detection \\
\hline Tefluthrin & Insecticide & 61606 & $79538-32-2$ & 0.010 & na & na & -1 \\
\hline Terbufos & Insecticide & 82675 & $13071-79-9$ & 0.018 & HAL-US & 0.4 & - \\
\hline Terbufos oxon sulfone & Insecticide degradate & 61674 & $56070-15-6$ & 0.045 & na & na & -1 \\
\hline Terbuthylazine & Herbicide & 04022 & $5915-41-3$ & 0.006 & na & na & - \\
\hline Tribufos & Defoliant & 61610 & $78-48-8$ & 0.018 & na & na & $-{ }^{1}$ \\
\hline Trifluralin & Herbicide & 82661 & $1582-09-8$ & 0.018 & HAL-US & 10 & - \\
\hline
\end{tabular}

${ }^{1}$ The median matrix-spike recovery was less than 70 percent. Low recoveries may indicate that the compound might not have been detected in some samples if it was present at very low concentrations.

${ }^{2}$ The median matrix-spike recovery was greater than 130 percent. High recoveries may indicate that reported values could be greater than what is in the sample. 


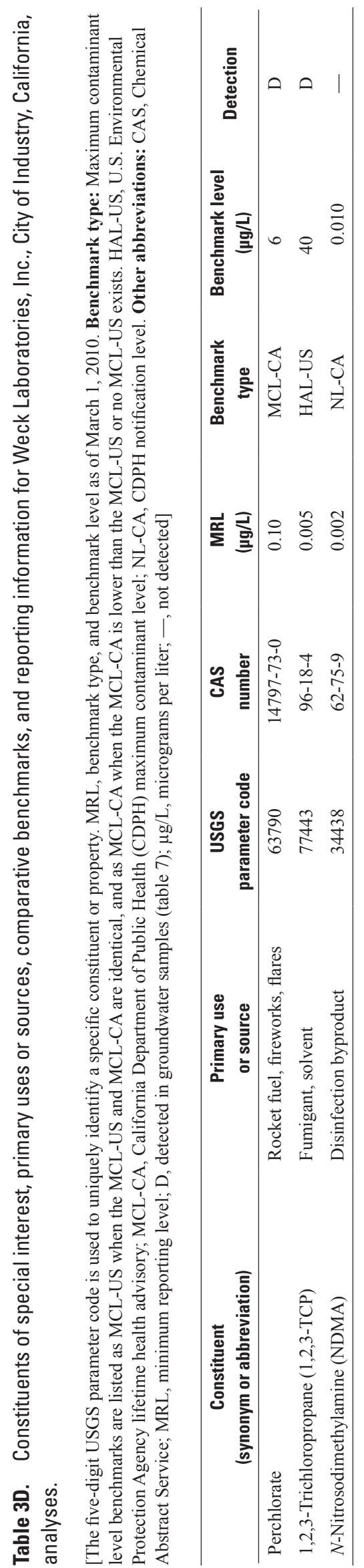


Table 3E. Trace elements, comparative benchmarks, and reporting information for the U.S. Geological Survey (USGS) National Water Quality Laboratory (NWOL) Schedule 1948.

[The five-digit USGS parameter code is used to uniquely identify a specific constituent or property. LRL, benchmark type, and benchmark level as of March 1, 2010. Benchmark type: Maximum contaminant level benchmarks are listed as MCL-US when the MCL-US and MCL-CA are identical, and as MCL-CA when the MCL-CA is lower than the MCL-US or no MCL-US exists. AL-US, U.S. Environmental Protection Agency (USEPA) action level; HAL-US, USEPA lifetime health advisory level; MCL-CA, California Department of Public Health (CDPH) maximum contaminant level; MCL-US, USEPA maximum contaminant level; NL-CA, CDPH notification level; SMCL-CA, CDPH secondary maximum contaminant level. Other abbreviations: CAS, Chemical Abstract Service; LRL, laboratory reporting level; SRL, study reporting level; D, detected in groundwater samples (table 8); na, not available; $\mu \mathrm{g} / \mathrm{L}$, micrograms per liter; -, not detected; WSJV, Western San Joaquin Valley study unit]

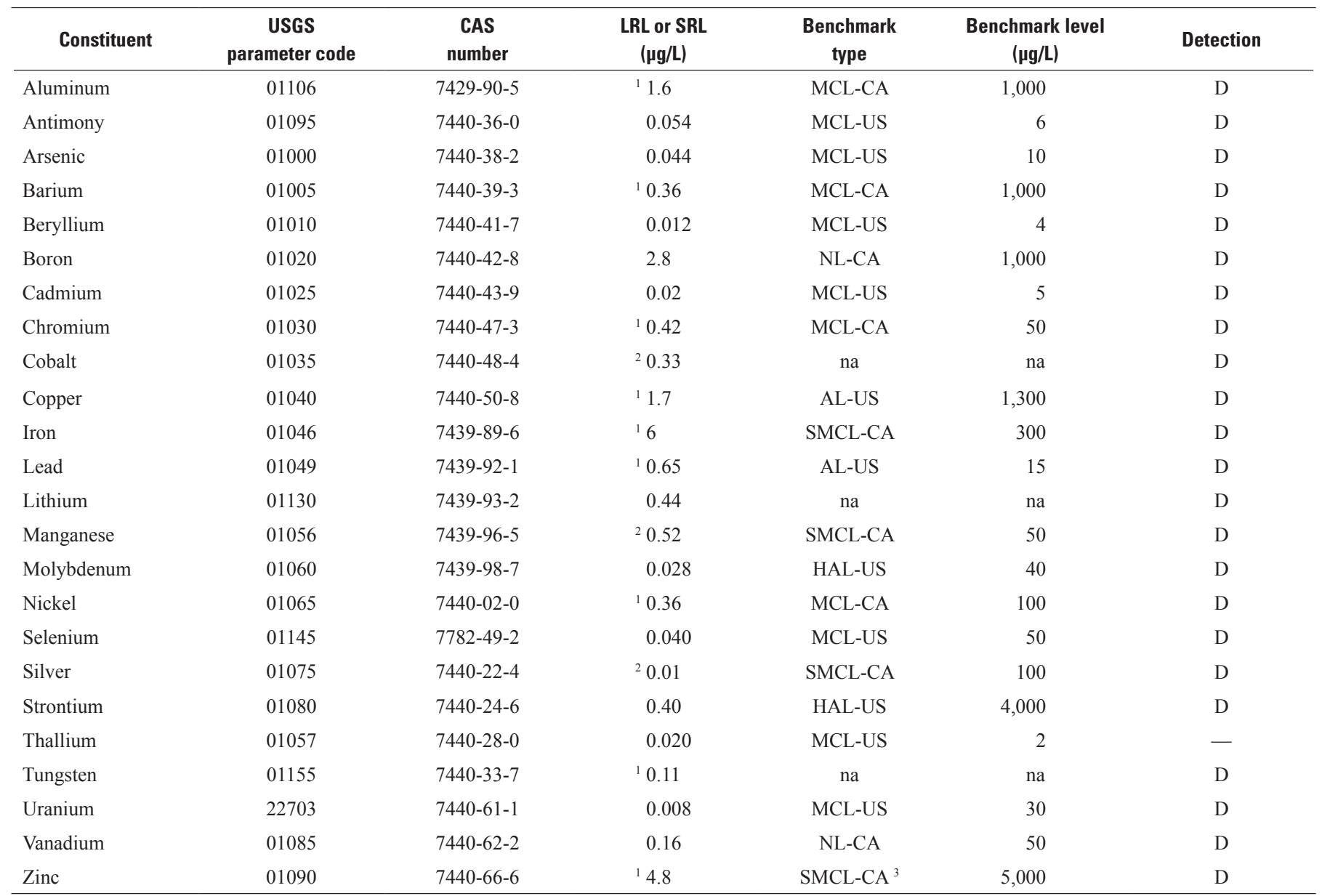

${ }^{1}$ The SRL was defined by Olsen and others (2010).

${ }^{2}$ The SRL was defined based on the highest concentration detected in the WSJV blanks.

${ }^{3}$ The secondary maximum contaminant level for zinc is listed as SMCL-CA because SMCLs established by CDPH are used in this report for all constituents that have SMCL-CA values. 


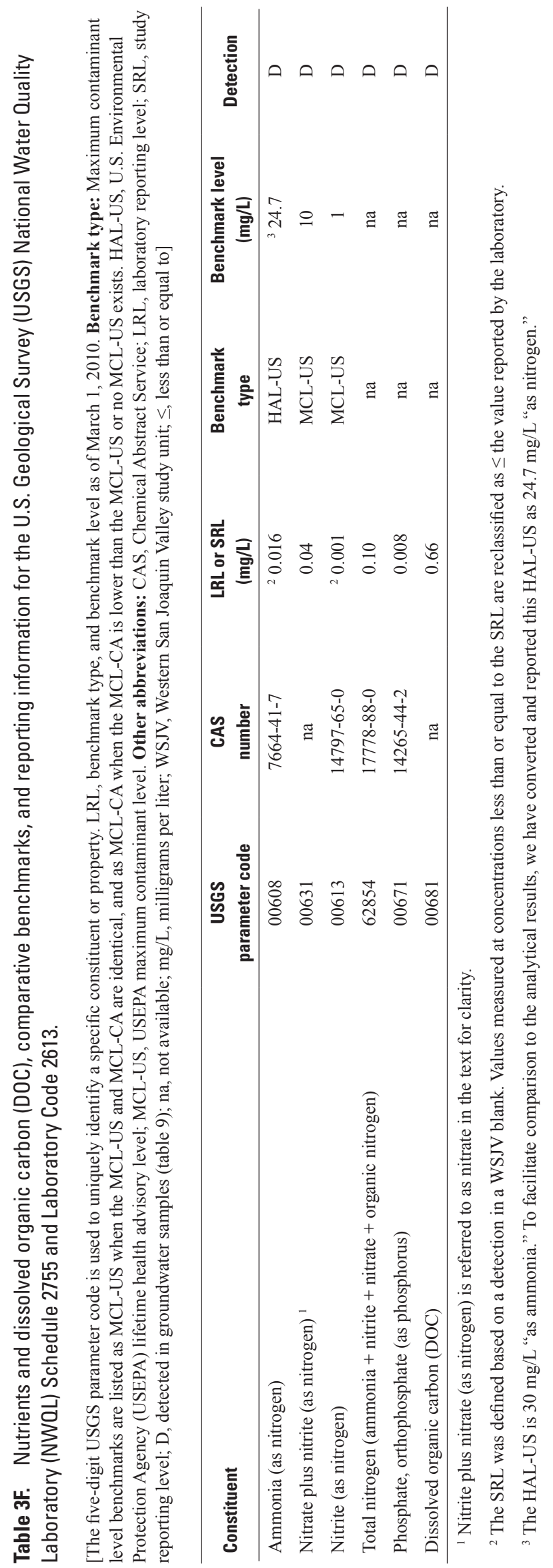


Table 3G. Major and minor ions, silica, total dissolved solids (TDS), and alkalinity, comparative benchmarks, and reporting information for the U.S. Geological Survey (USGS) National Water Quality Laboratory (NWOL) Schedule 1948.

[The five-digit USGS parameter code is used to uniquely identify a specific constituent or property. LRL, benchmark type, and benchmark level as of March 1, 2010. Benchmark type: Maximum contaminant level benchmarks are listed as MCL-US when the MCL-US and MCL-CA are identical, and as MCL-CA when the MCL-CA is lower than the MCL-US or no MCL-US exists. MCL-CA, California Department of Public Health (CDPH) maximum contaminant level; SMCL-CA, CDPH secondary maximum contaminant level. Other abbreviations: CAS, Chemical Abstract Service; LRL, laboratory reporting level; $\mathrm{D}$, detected in groundwater samples (table 10 ); na, not available; $\mathrm{mg} / \mathrm{L}$, milligrams per liter; $\mathrm{SiO}_{2}$, silicon dioxide; $\mathrm{CaCO}_{3}$, calcium carbonate]

\begin{tabular}{|c|c|c|c|c|c|c|}
\hline $\begin{array}{c}\text { Constituent } \\
\text { (synonym or abbreviation) }\end{array}$ & $\begin{array}{c}\text { USGS } \\
\text { parameter code }\end{array}$ & $\begin{array}{c}\text { CAS } \\
\text { number }\end{array}$ & $\begin{array}{c}\text { LRL } \\
(\mathrm{mg} / \mathrm{L})\end{array}$ & $\begin{array}{l}\text { Benchmark } \\
\text { type }\end{array}$ & $\begin{array}{c}\text { Benchmark level } \\
\text { (mg/L) }\end{array}$ & Detection \\
\hline Bromide & 71870 & $24959-67-9$ & 0.02 & na & na & $\mathrm{D}$ \\
\hline Chloride & 00940 & $16887-00-6$ & 0.12 & SMCL-CA & ${ }^{1} 250(500)$ & $\mathrm{D}$ \\
\hline Fluoride & 00950 & $16984-48-8$ & 0.08 & MCL-CA & 2 & $\mathrm{D}$ \\
\hline Iodide & 71865 & $7553-56-2$ & 0.002 & na & na & $\mathrm{D}$ \\
\hline Potassium & 00935 & $7440-09-7$ & 0.064 & na & na & $\mathrm{D}$ \\
\hline Sodium & 00930 & $7440-23-5$ & 0.10 & na & na & $\mathrm{D}$ \\
\hline Sulfate & 00945 & $14808-79-8$ & 0.18 & SMCL-CA & ${ }^{1} 250(500)$ & $\mathrm{D}$ \\
\hline Silica $\left(\right.$ as $\mathrm{SiO}_{2}$ ) & 00955 & $7631-86-9$ & 0.058 & na & na & $\mathrm{D}$ \\
\hline Total dissolved solids (TDS) & 70300 & na & 10 & SMCL-CA & ${ }^{1} 500(1,000)$ & $\mathrm{D}$ \\
\hline
\end{tabular}

${ }^{1}$ The SMCL-CA benchmarks for chloride, sulfate, and TDS have recommended and upper benchmark levels. The upper benchmark level is shown in parentheses.

${ }^{2}$ Laboratory alkalinity results are presented in table 4.

Table 3H. Total arsenic and iron (unfiltered) and arsenic, chromium, and iron species (filtered), comparative benchmarks, and reporting information for the U.S. Geological Survey (USGS) National Research Laboratory (NRP) Trace Metal Laboratory (TML), Boulder, Colorado, analyses.

[The five-digit USGS parameter code is used to uniquely identify a specific constituent or property. MDL, benchmark type, and benchmark level as of March 1, 2010. Benchmark type: Maximum contaminant level benchmarks are listed as MCL-US when the MCL-US and MCL-CA are identical, and as MCL-CA when the MCL-CA is lower than the MCL-US or no MCL-US exists. MCL-CA, California Department of Public Health (CDPH) maximum contaminant level; MCL-US, U.S. Environmental Protection Agency maximum contaminant level; SMCL-CA, CDPH secondary maximum contaminant level. Other abbreviations: CAS, Chemical Abstract Service; MDL, method detection limit; na, not available; $\mu \mathrm{g} / \mathrm{L}$, micrograms per liter; D, detected in groundwater samples (table 11)]

\begin{tabular}{|c|c|c|c|c|c|c|}
\hline Constituent & $\begin{array}{c}\text { USGS } \\
\text { parameter code }\end{array}$ & $\begin{array}{c}\text { CAS } \\
\text { number }\end{array}$ & $\begin{array}{c}\text { MDL } \\
(\mu \mathrm{g} / \mathrm{L})\end{array}$ & $\begin{array}{l}\text { Benchmark } \\
\text { type }\end{array}$ & $\begin{array}{c}\text { Benchmark level } \\
(\mu \mathrm{g} / \mathrm{L})\end{array}$ & Detection \\
\hline Arsenic (total, unfiltered) & na & na & 0.5 & MCL-US & 10 & $\mathrm{D}$ \\
\hline Arsenic (total, filtered) & 99033 & $7440-38-2$ & 0.5 & MCL-US & 10 & $\mathrm{D}$ \\
\hline Chromium (total, filtered) & 01030 & $7440-47-3$ & 1 & MCL-CA & 50 & $\mathrm{D}$ \\
\hline Chromium-VI (filtered) & 01032 & $18540-29-9$ & 1 & na & na & $\mathrm{D}$ \\
\hline Iron-II (filtered) & 01047 & $7439-89-6$ & 2 & na & na & $\mathrm{D}$ \\
\hline Iron (total, filtered) & 01046 & $7439-89-6$ & 2 & SMCL-CA & 300 & $\mathrm{D}$ \\
\hline
\end{tabular}


Table 3l. Isotopic tracers, comparison benchmarks, and reporting information for laboratory analyses.

[The five-digit USGS parameter code is used to uniquely identify a specific constituent or property. Laboratory entity codes in the USGS National Water Information System (NWIS) for laboratories other than the USGS National Water Quality Laboratory (NWQL) are given in parentheses after the laboratory names. Benchmark type and benchmark value as of March 1, 2010. Benchmark type: Maximum contaminant level benchmarks are listed as MCL-US when the MCL-US and MCL-CA are identical, and as MCL-CA when the MCL-CA is lower than the MCL-US or no MCL-US exists. MCL-CA, California Department of Public Health maximum contaminant level. Elements: H, hydrogen; O, oxygen; N, nitrogen; S, sulfur; B, boron; Sr, strontium; C, carbon. R eporting units: $\mu \mathrm{g} / \mathrm{L}$, micrograms per liter; $\mathrm{mg} / \mathrm{L}$, milligrams per liter; $\mathrm{pCi} / \mathrm{L}$, picocuries per liter; $\mathrm{cm}^{3} \mathrm{STP} / \mathrm{g}$, cubic centimeters of gas at standard temperature and pressure per gram of water. Other abbreviations: CAS, Chemical Abstract Service; na, not available; D, detected in groundwater samples (tables 12 and 13 ); $\%$, percent; pmc, percent modern carbon; NRP, National Research Program]

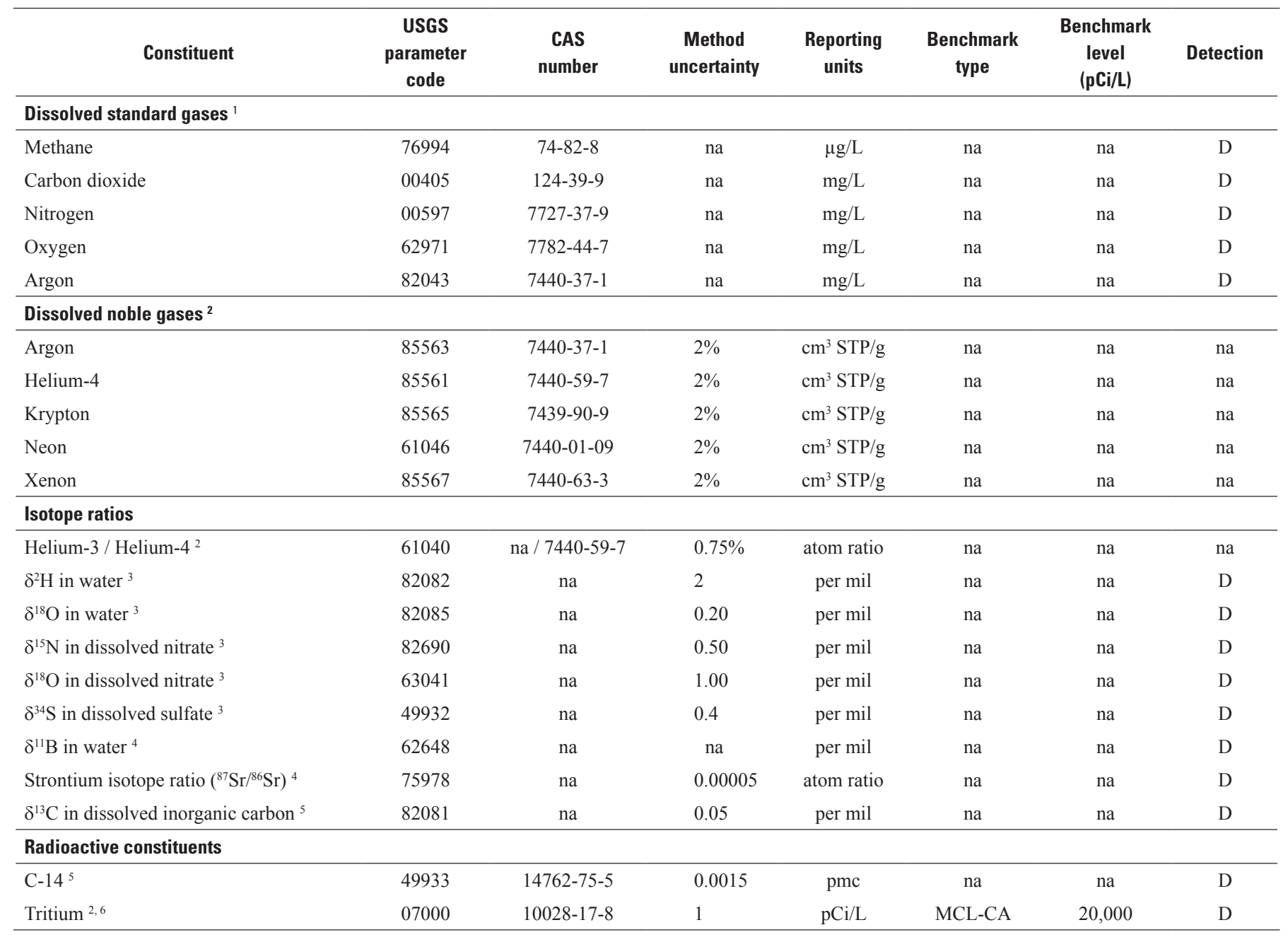

${ }^{1}$ USGS Chlorofluorocarbon Laboratory, Reston, Virginia (USGSCFCVA).

${ }^{2}$ Lawrence Livermore National Laboratory, Livermore, California (CA-LLNL).

${ }^{3}$ USGS Stable Isotope Laboratory, Reston, Virginia (USGSSIVA).

${ }^{4}$ USGS NRP Metals Isotope Research Laboratory, Menlo Park, California (USGSMICA).

${ }^{5}$ Woods Hole Oceanographic Institution, National Ocean Sciences Accelerator Mass Spectrometry Facility [NOMAS], Woods Hole, Massachusetts (MA-WHAMS).

${ }^{6}$ USGS Stable Isotope and Tritium Laboratory [SITL], Menlo Park, California (USGSH3CA). SITL tritium data are reported using the conventions used by the USGS for radioactive consituents (see table 12). 


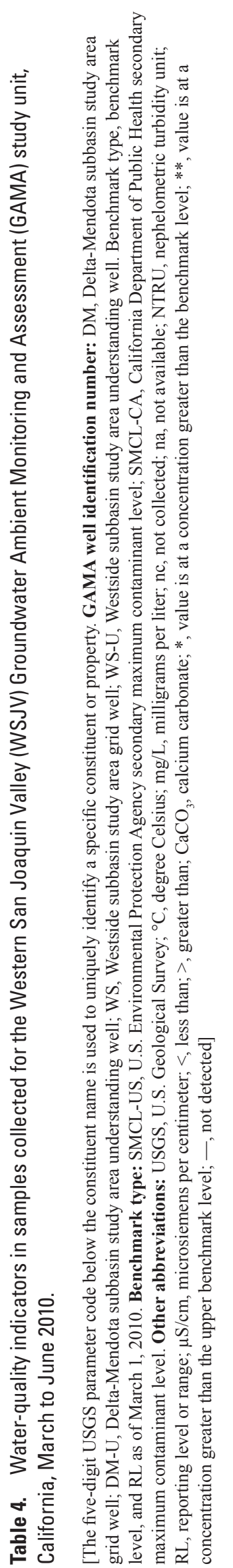

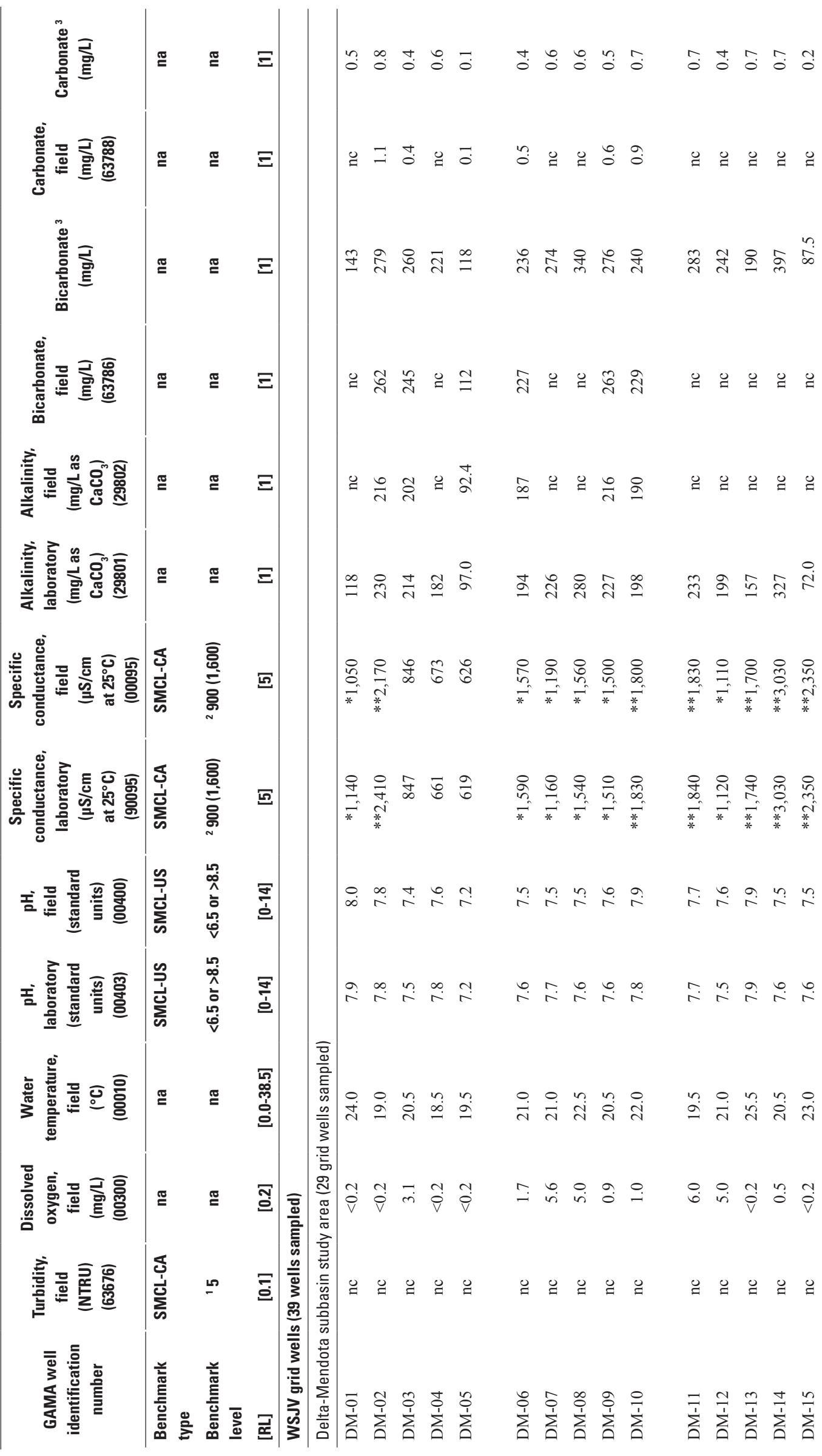



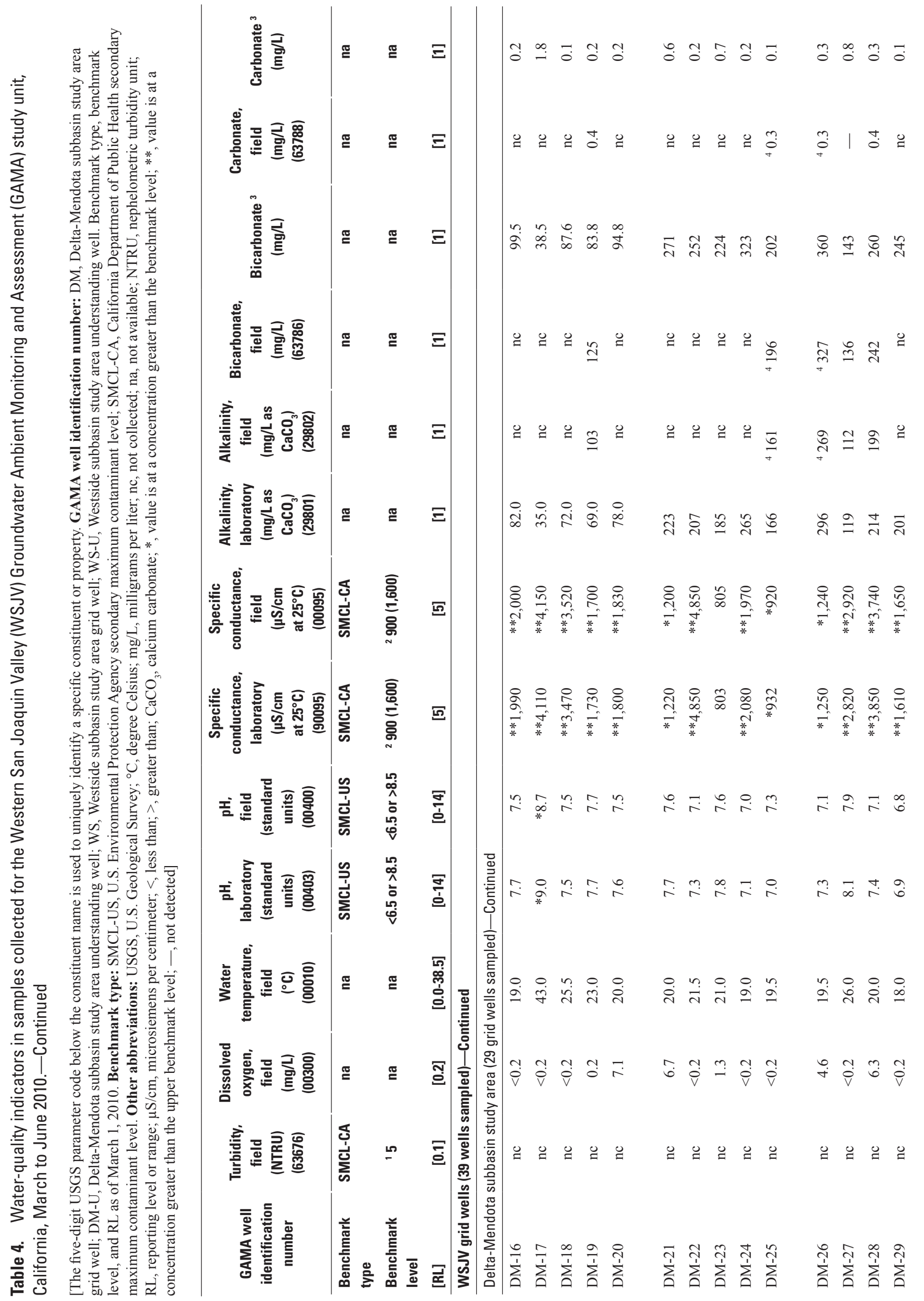

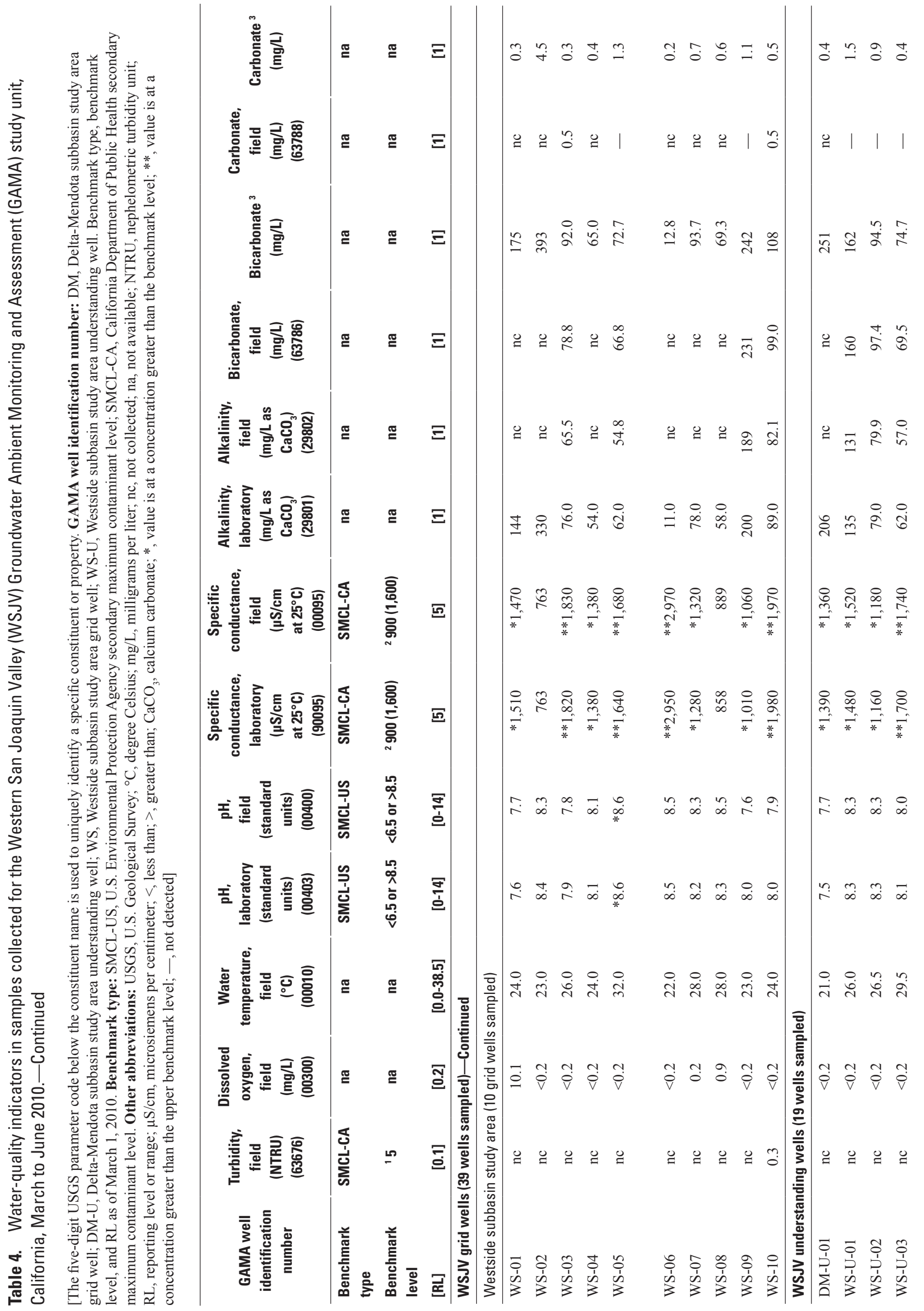

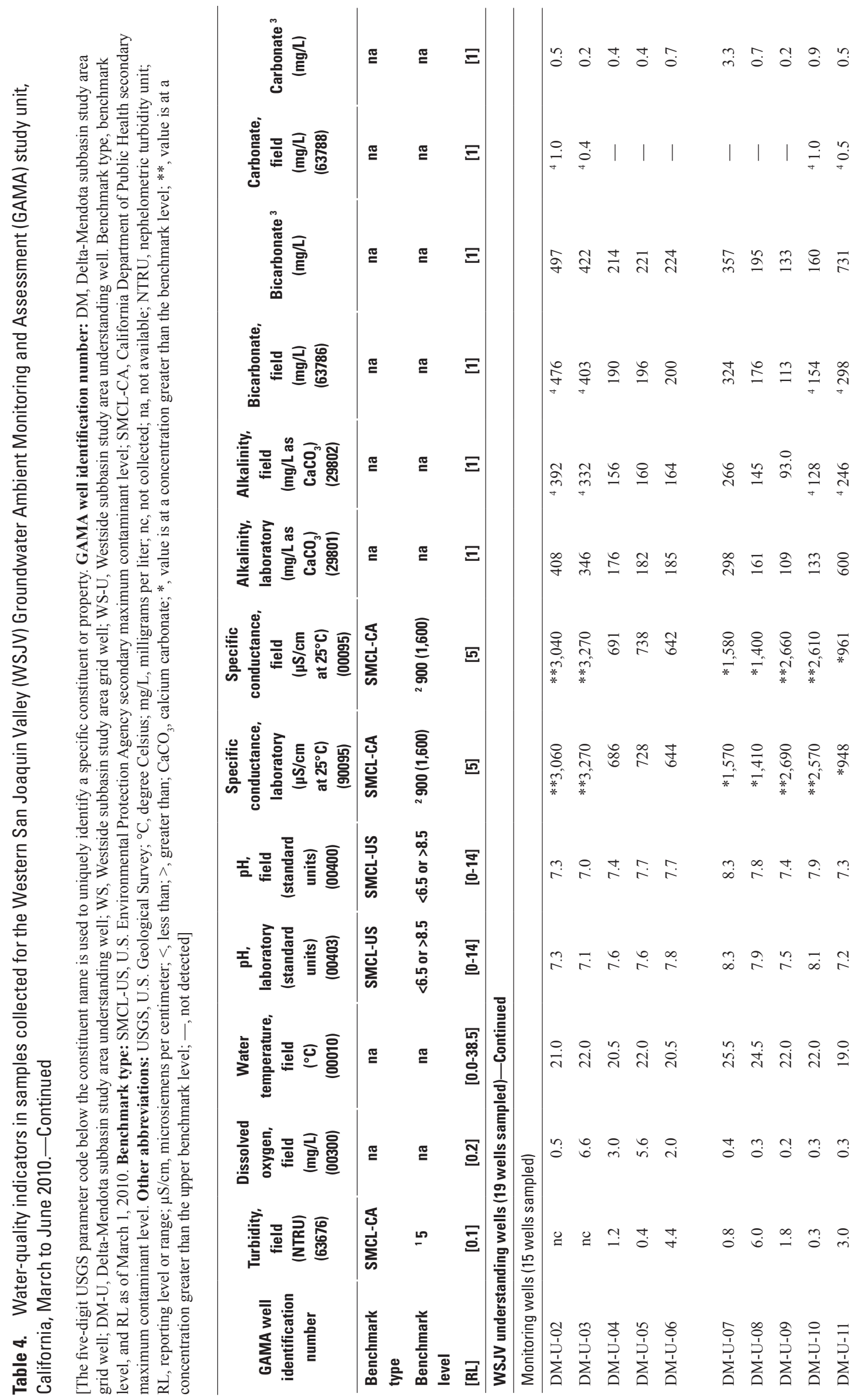

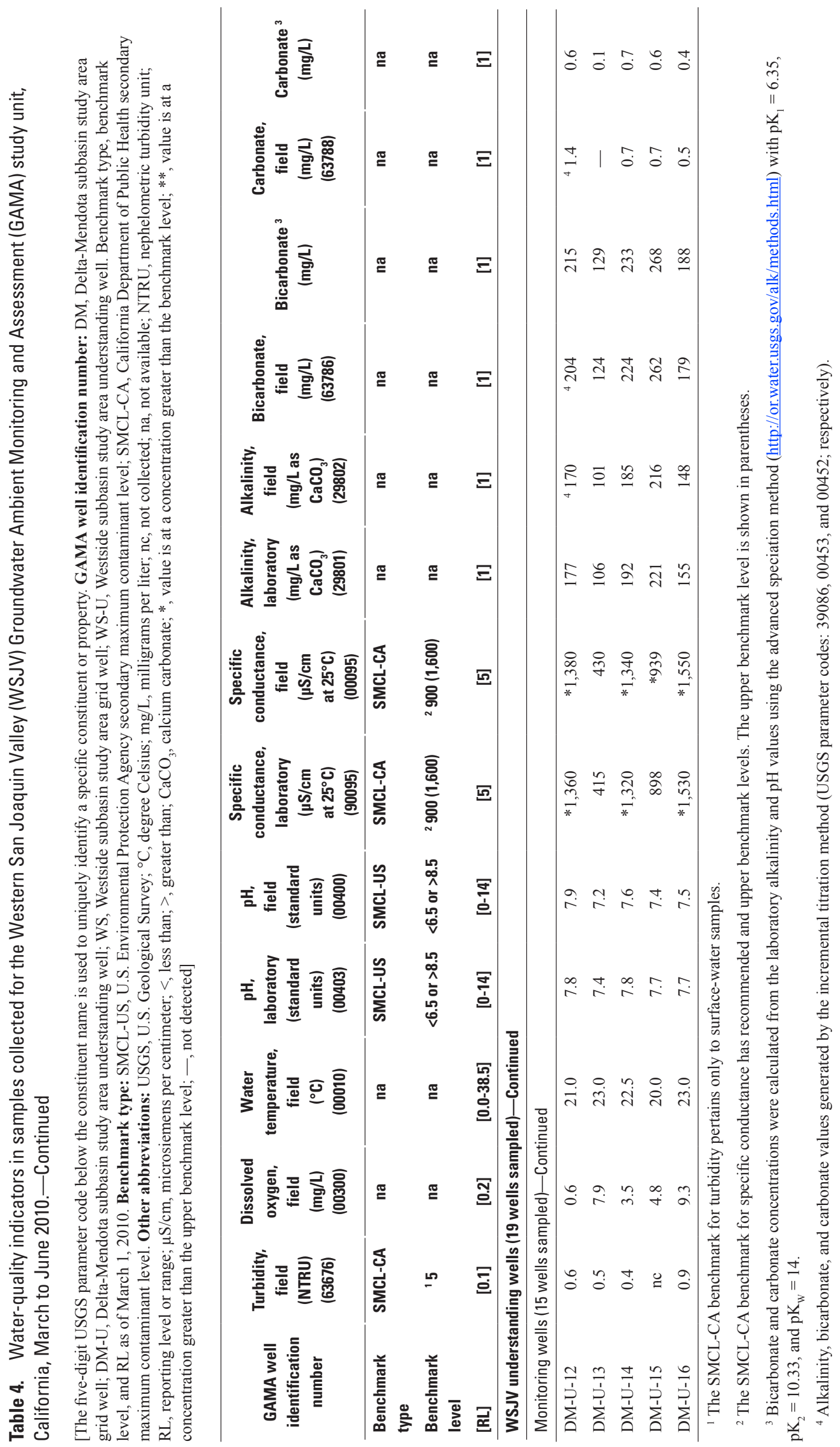

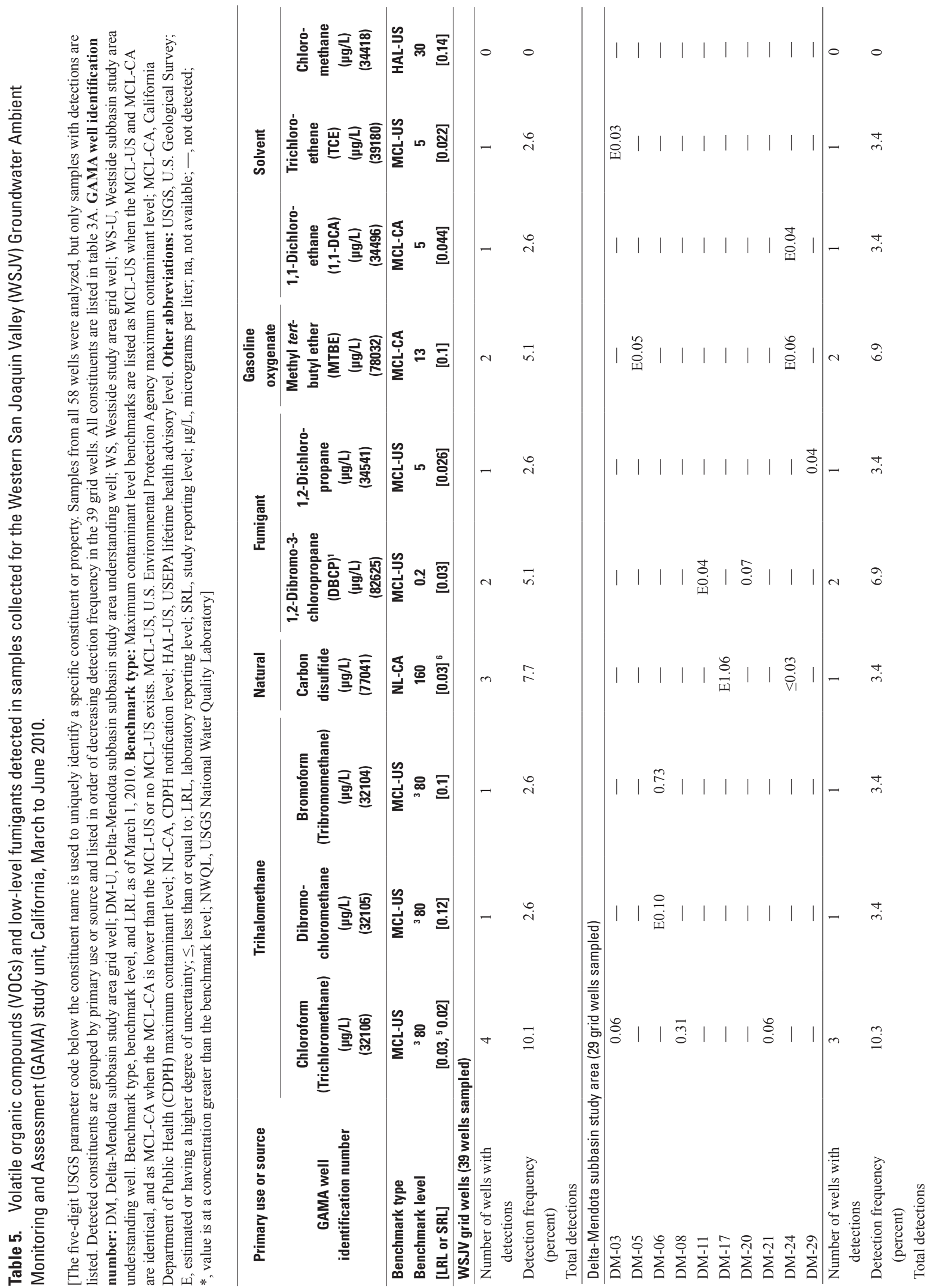
Table $5 \quad 47$

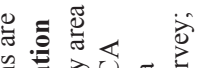

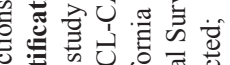

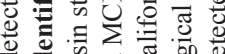

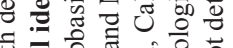

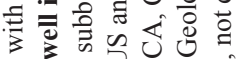

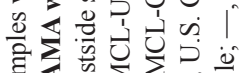

过 $\sum^{2} \sum_{0}$

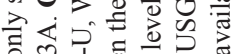

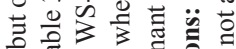

胥.

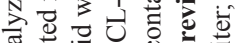

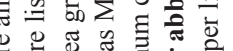

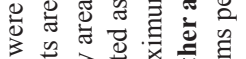

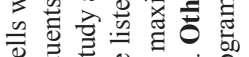

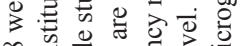

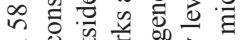

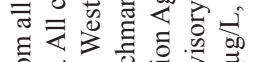

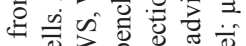

讨 3

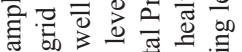

竹

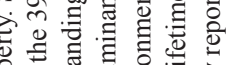

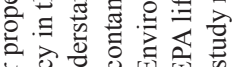

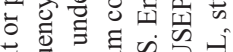

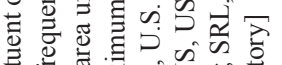

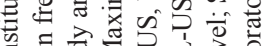

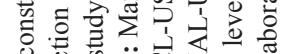

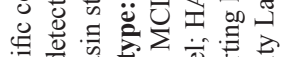

造 on

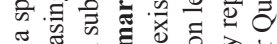

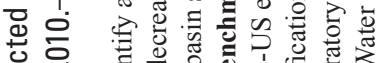

ญิ

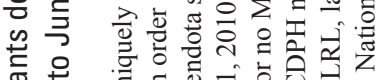

.

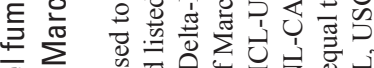

ब地

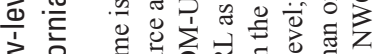

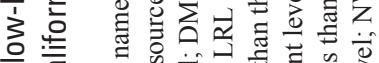

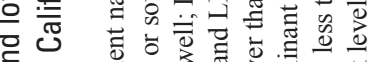

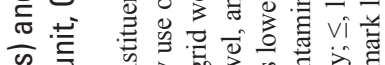

कु

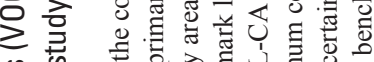

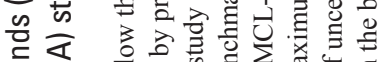

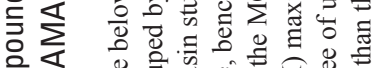

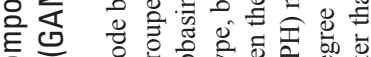

등 은

.

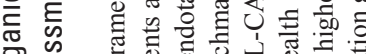

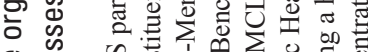

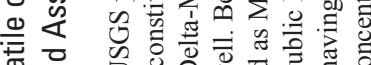

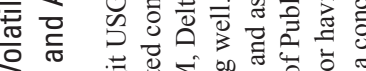

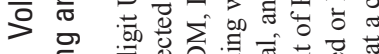

เ

ம

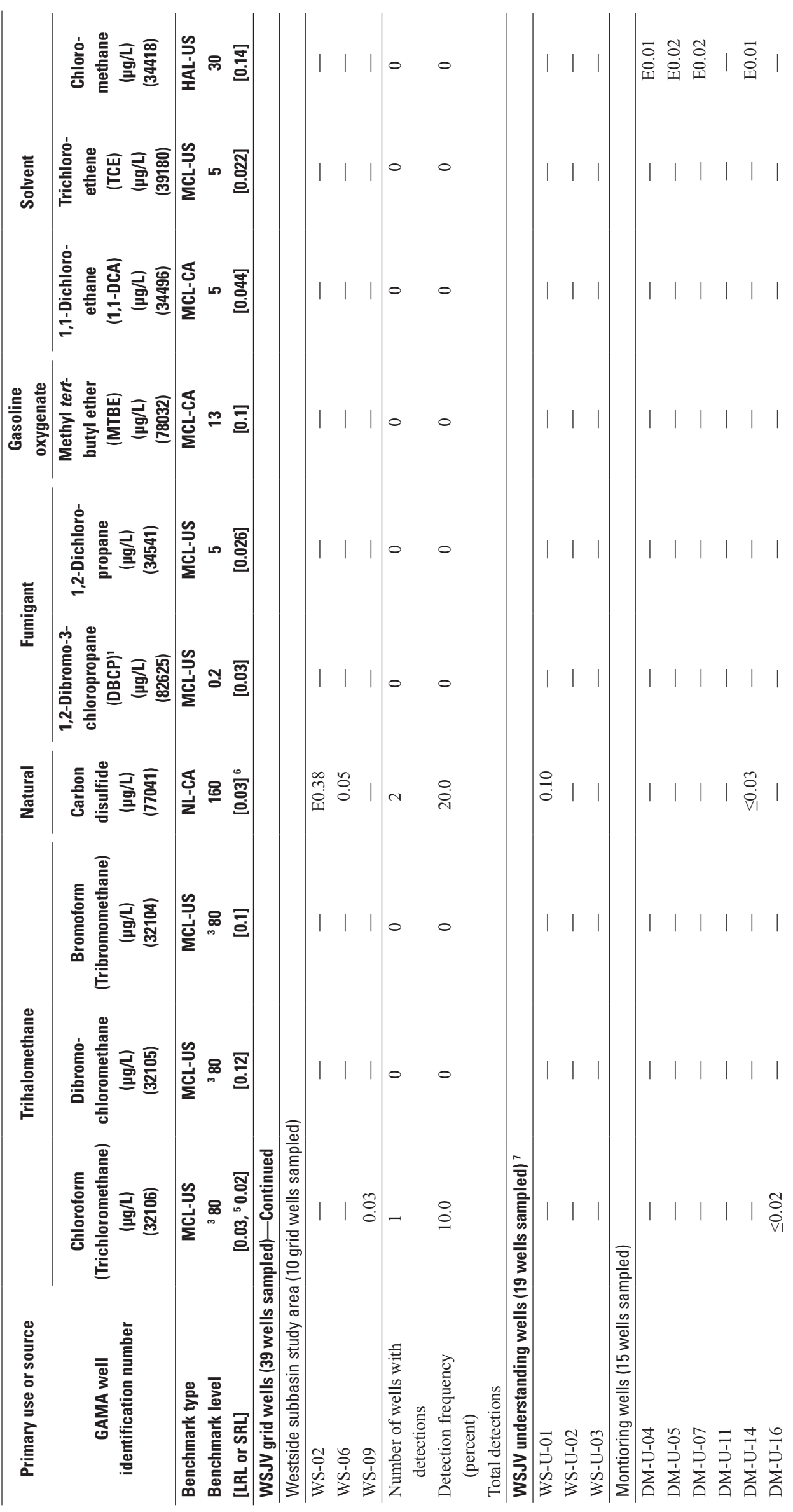




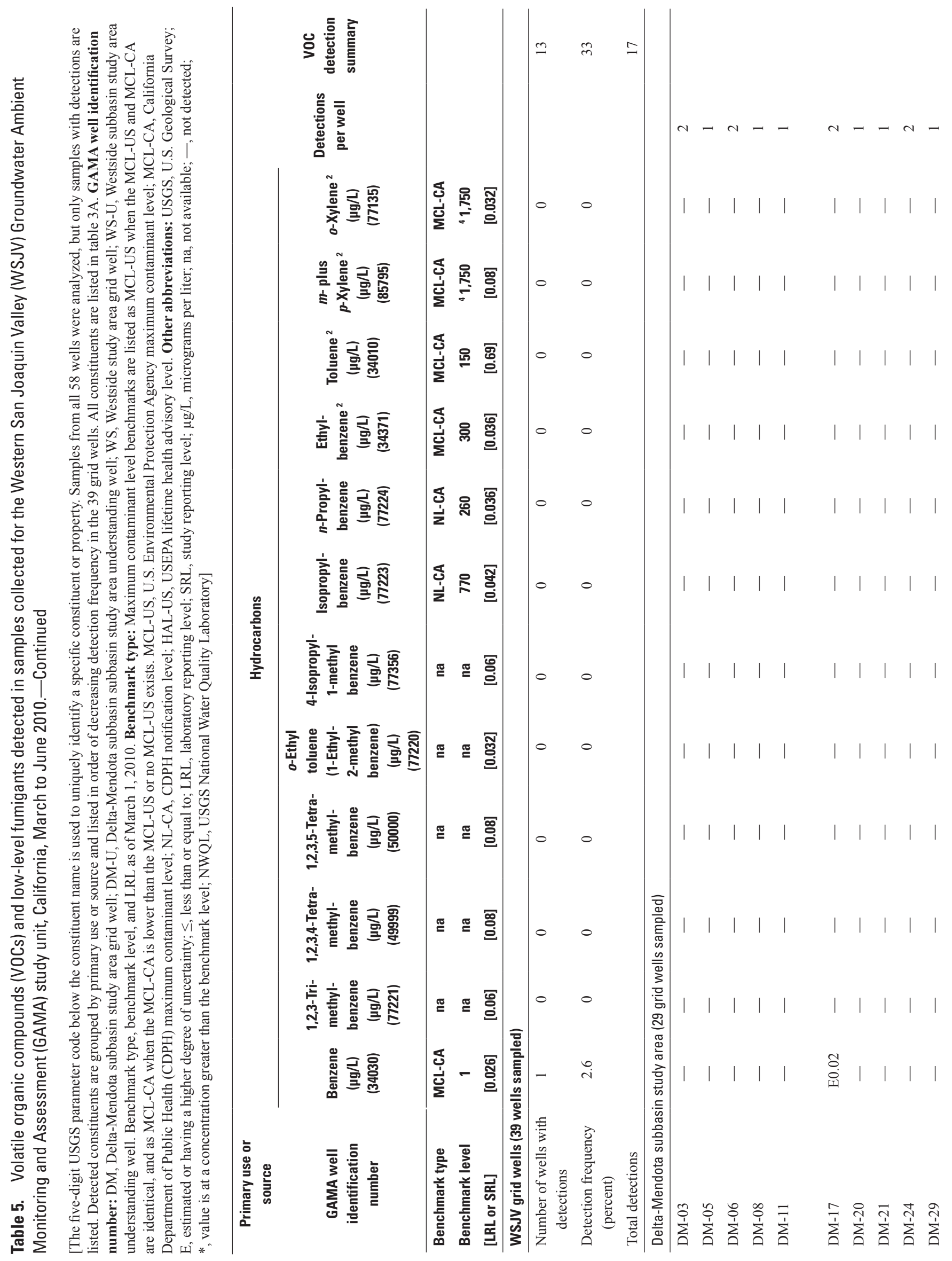


Table $5 \quad 49$

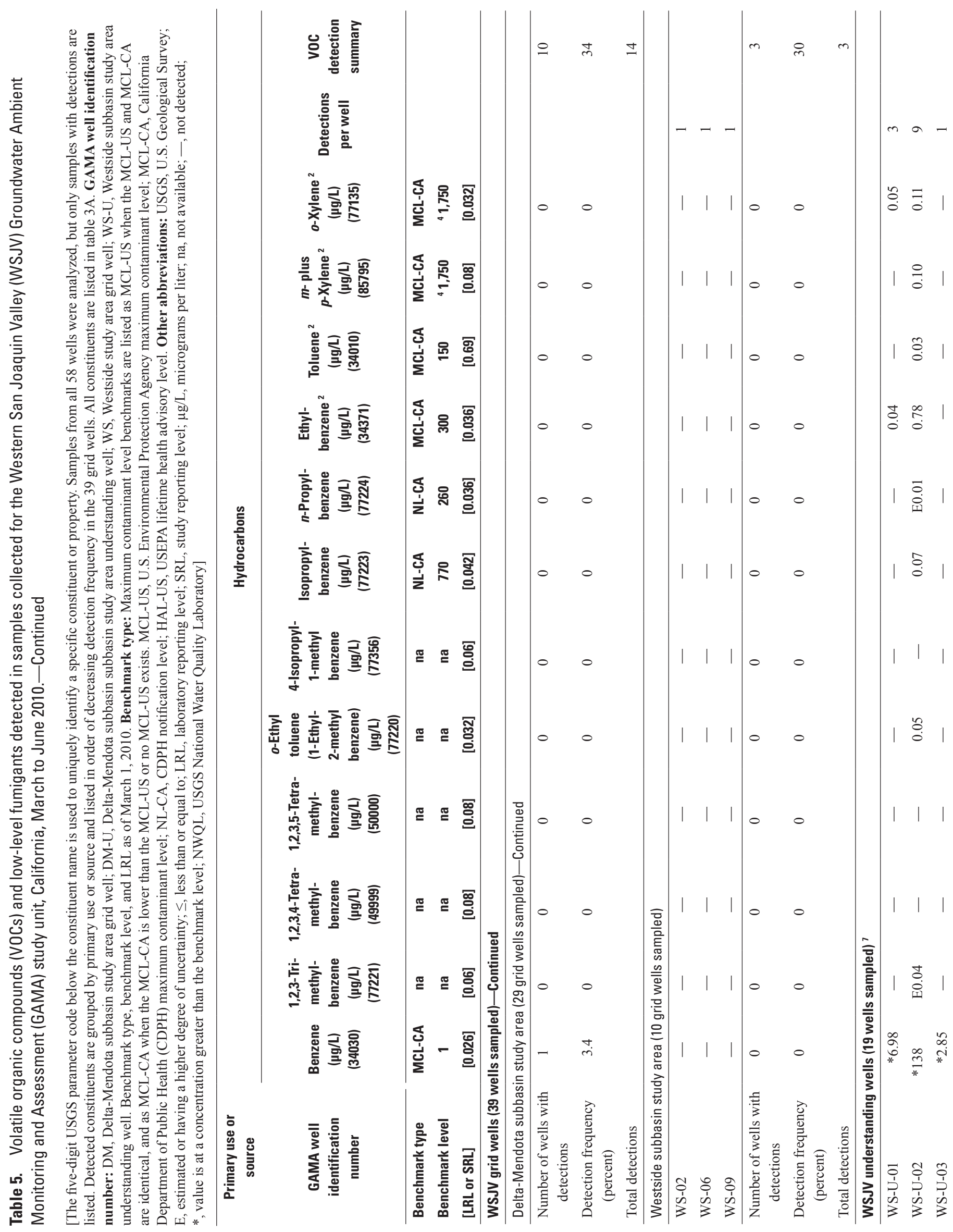




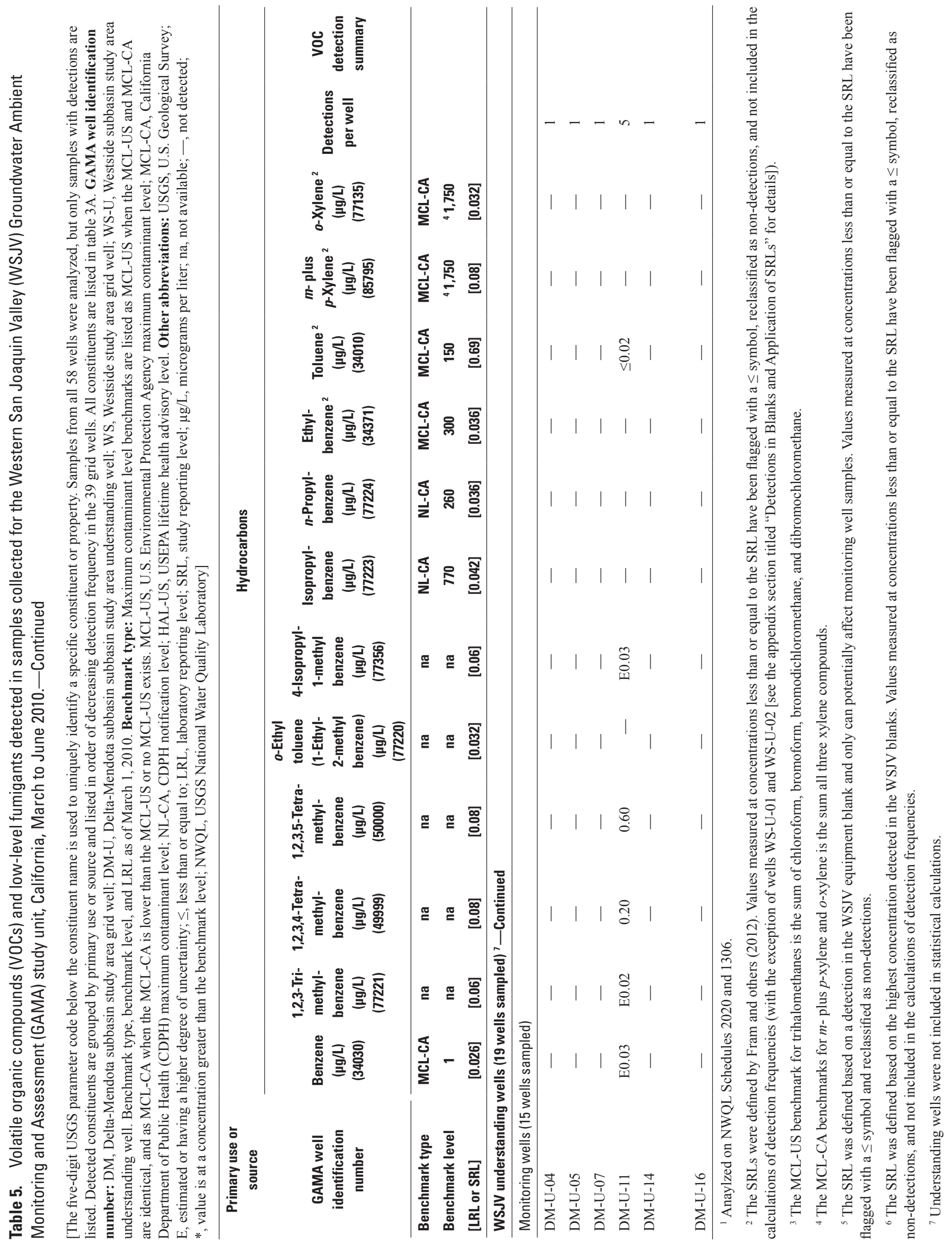




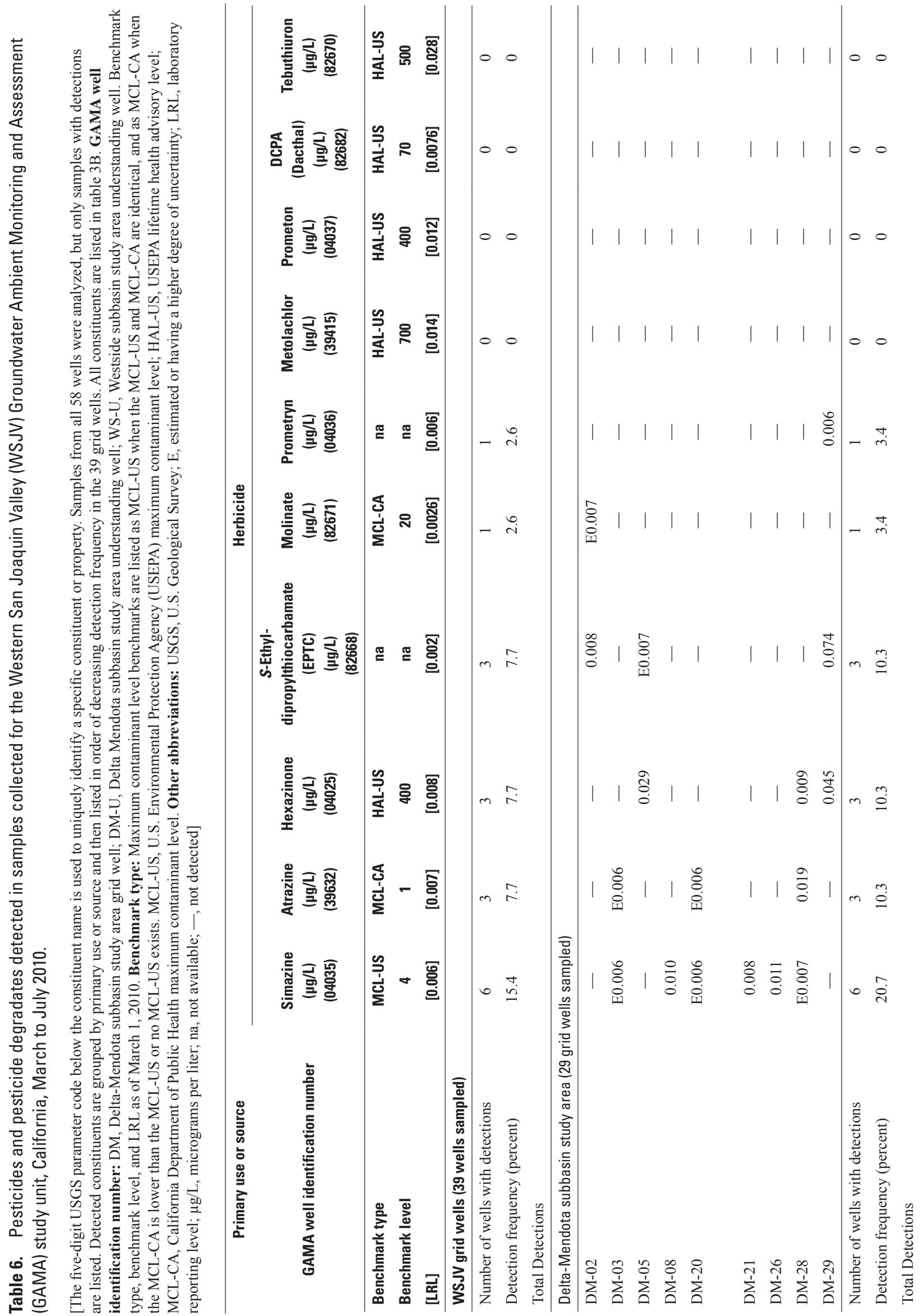




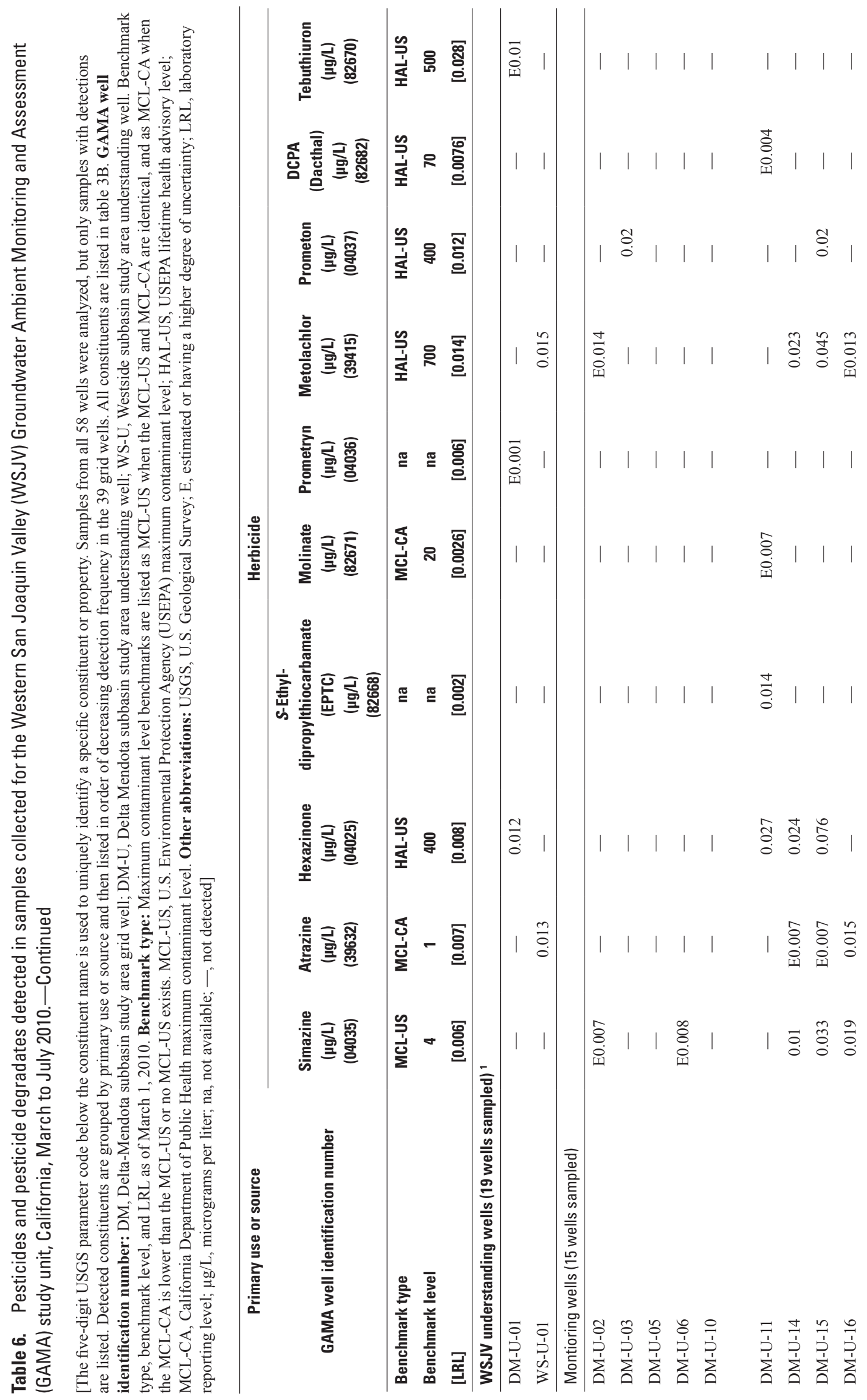




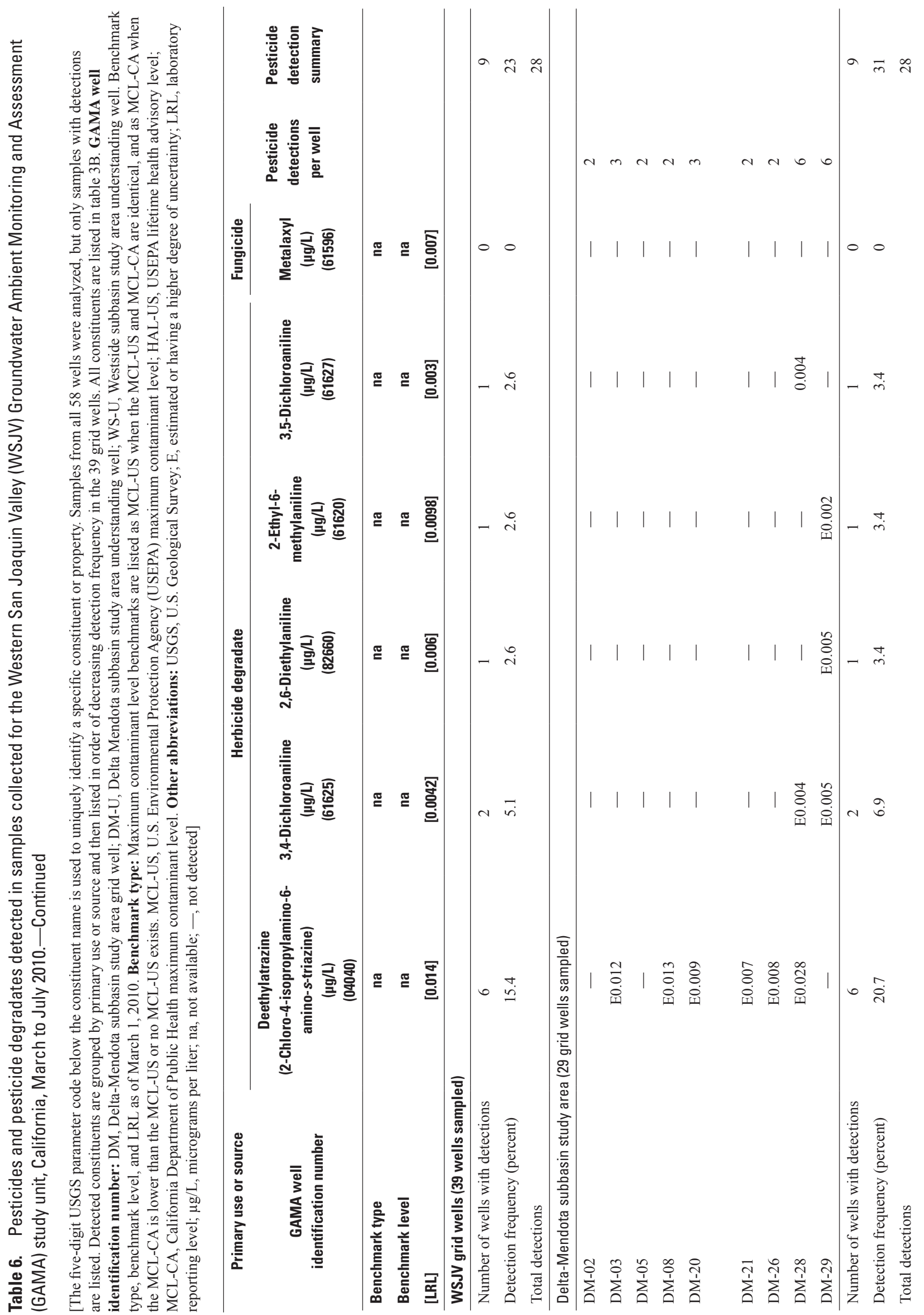




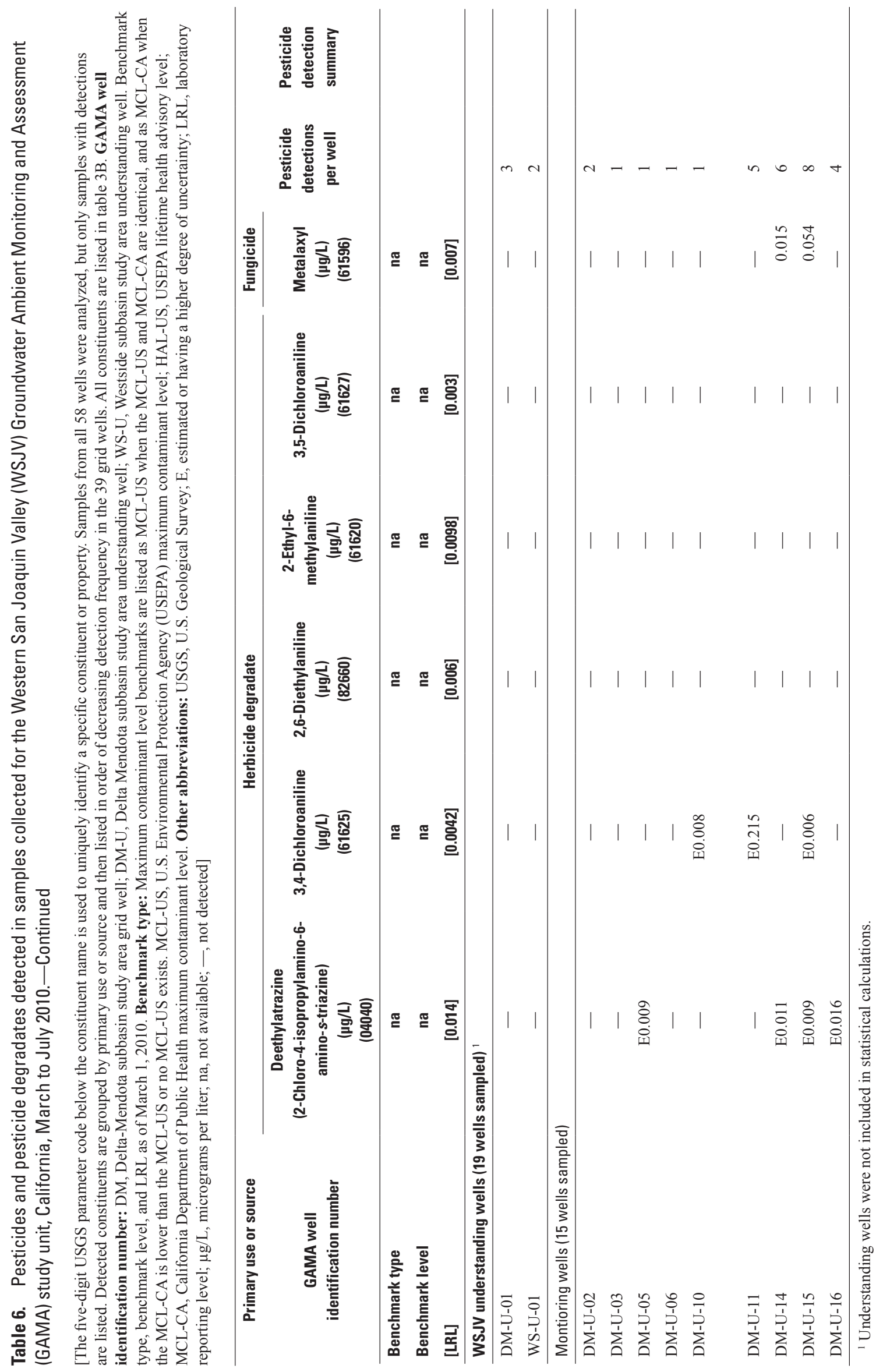


Table 7. Constituents of special interest detected in the samples collected for the Western San Joaquin Valley (WSJV) Groundwater Ambient Monitoring and Assessment (GAMA) study unit, California, March to July 2010.

[The five-digit USGS parameter code below the constituent name is used to uniquely identify a specific constituent or property. Information about the constituent given in table 3D. Samples from all 58 wells were analyzed for perchlorate and 1,2,3-TCP. Samples from the 33 slow wells were analyzed for NDMA. Only well samples with detections are listed. GAMA well identification number: DM, Delta-Mendota subbasin study area grid well; DM-U, Delta-Mendota subbasin study area understanding well; WS, Westside subbasin study area grid well. Benchmark type, benchmark level, and MRL as of March 1, 2010. Benchmark type: Maximum contaminant level benchmarks are listed as MCL-US when the MCL-US and MCL-CA are identical, and as MCL-CA when the MCL-CA is lower than the MCL-US or no MCL-US exists. MCL-CA, California Department of Public Health maximum contaminant level; HAL-US, U.S. Environmental Protection Agency lifetime health advisory level. Other abbreviations: USGS, U.S. Geological Survey; 1,2,3-TCP, 1,2,3-Trichloropropane; NDMA, $N$-Nitrosodimethylamine; MRL, method reporting level; $\mu \mathrm{g} / \mathrm{L}$, micrograms per liter; —, not detected]

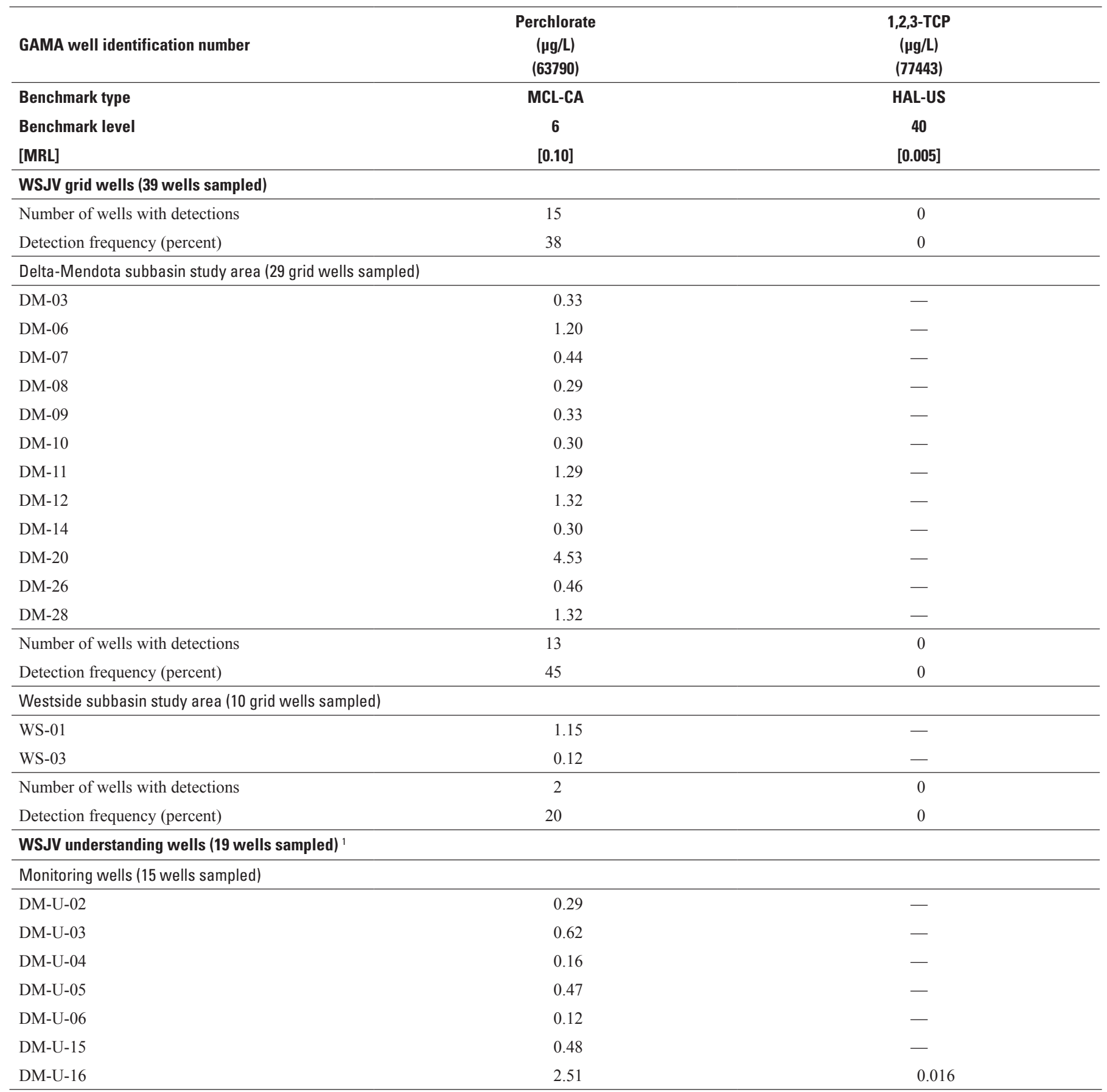

\footnotetext{
${ }^{1}$ Understanding wells were not included in statistical calculations.
} 


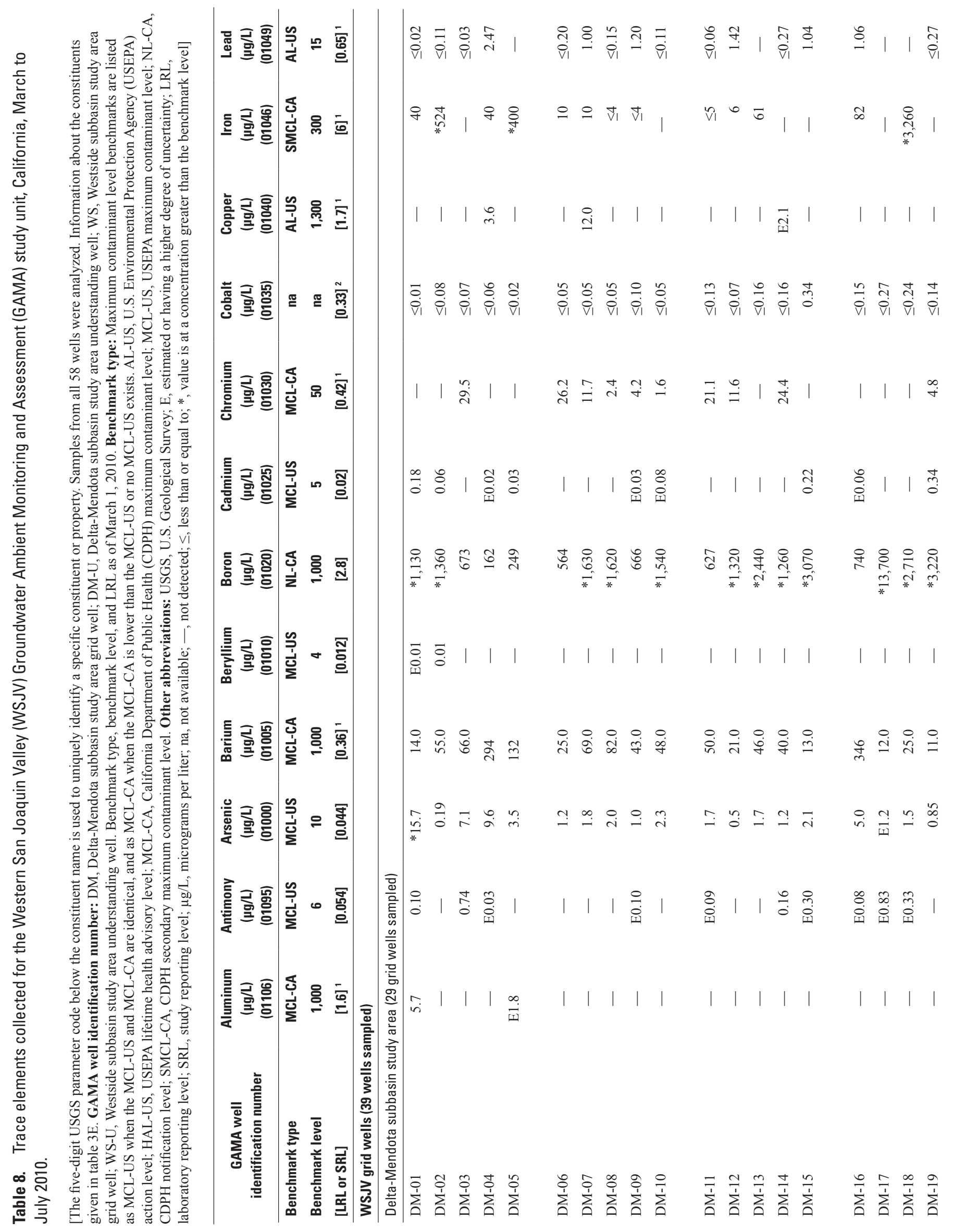




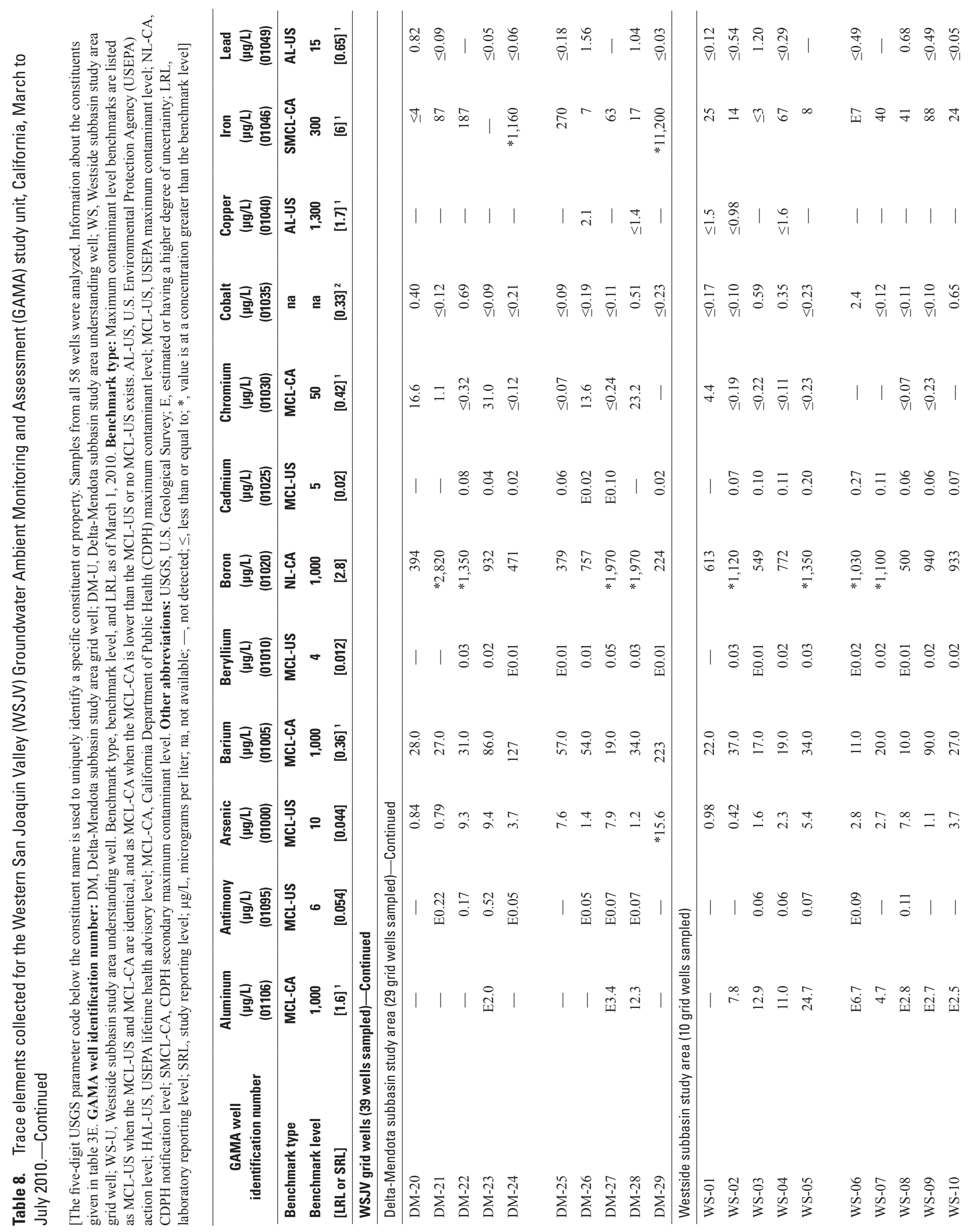




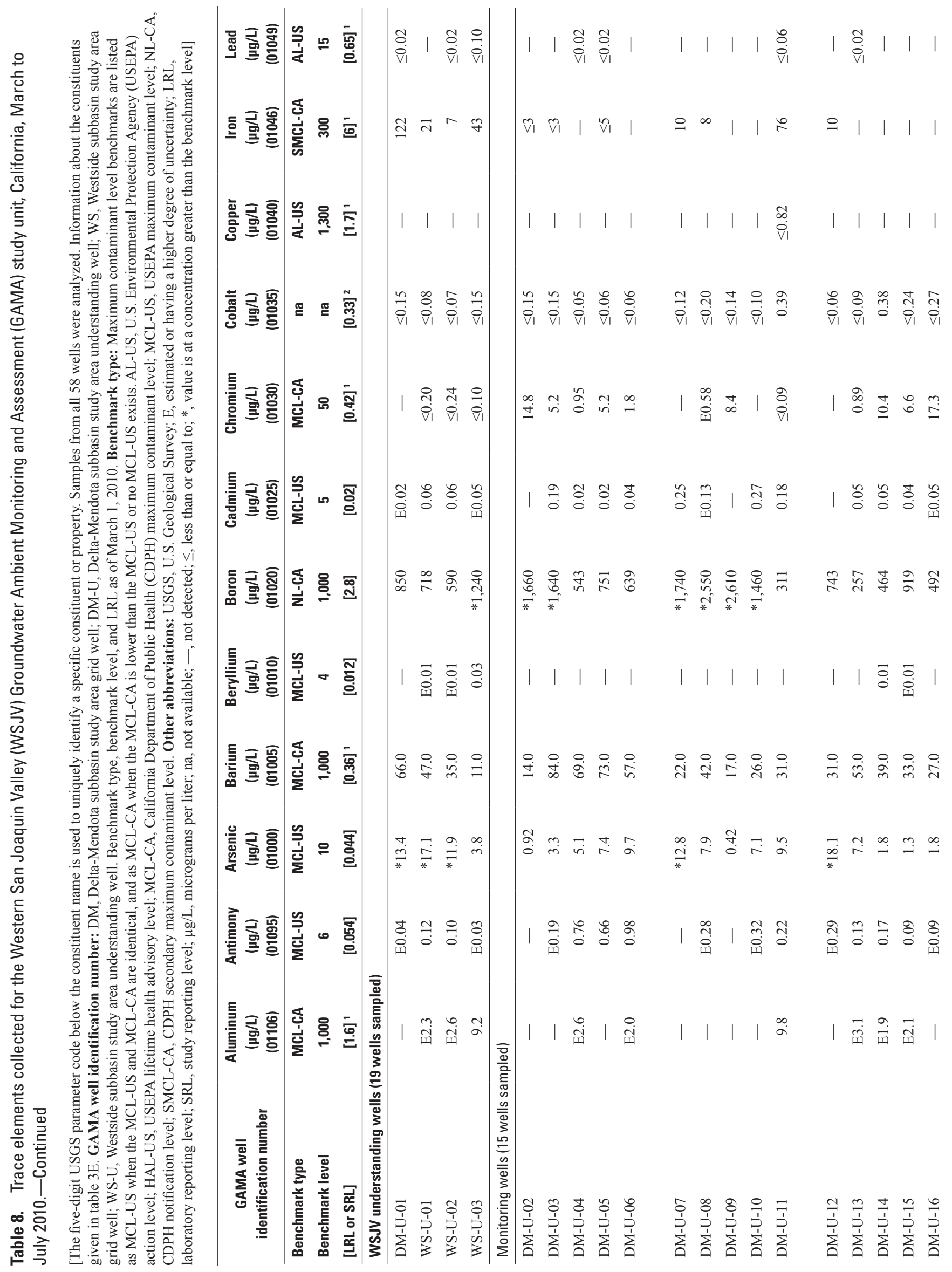




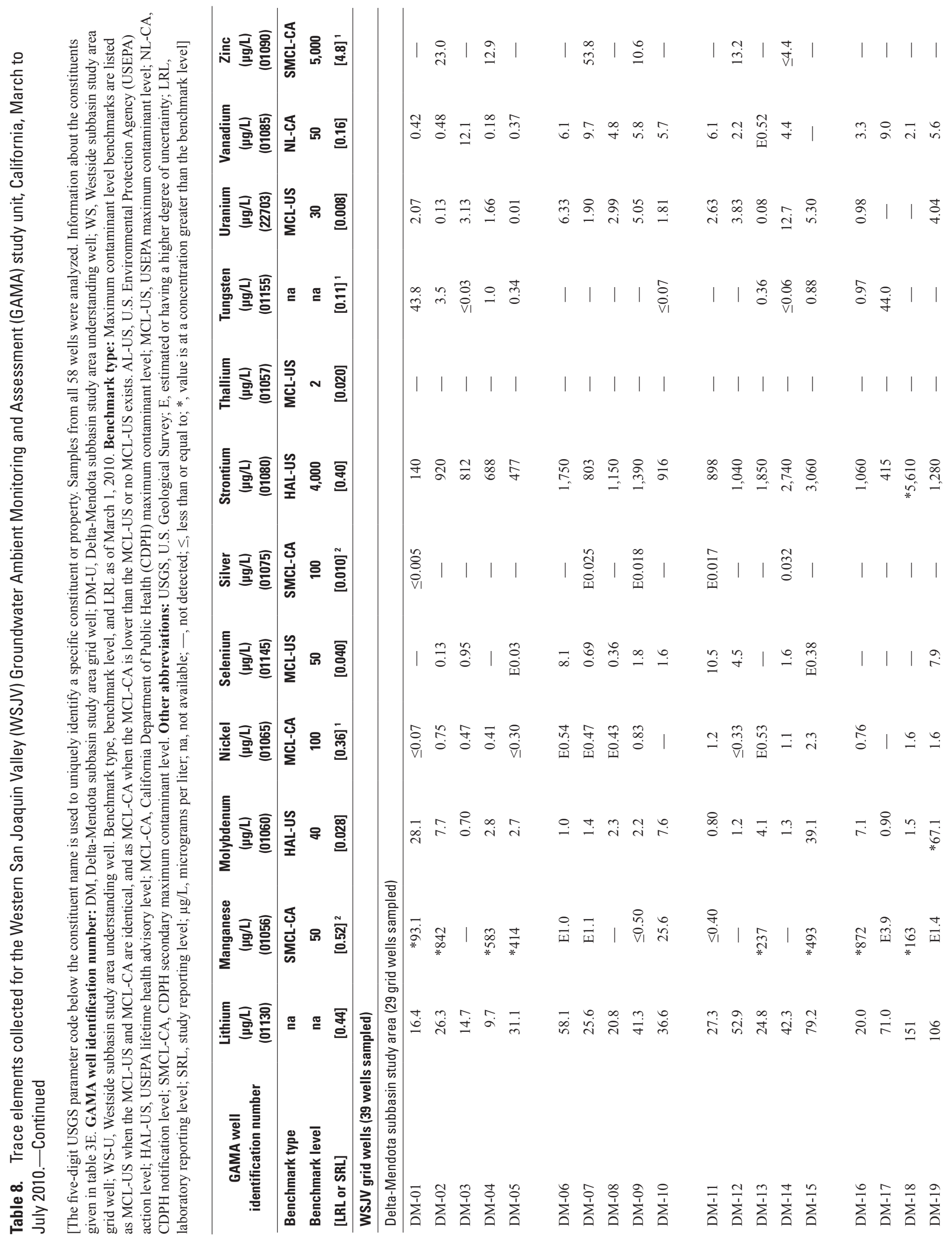




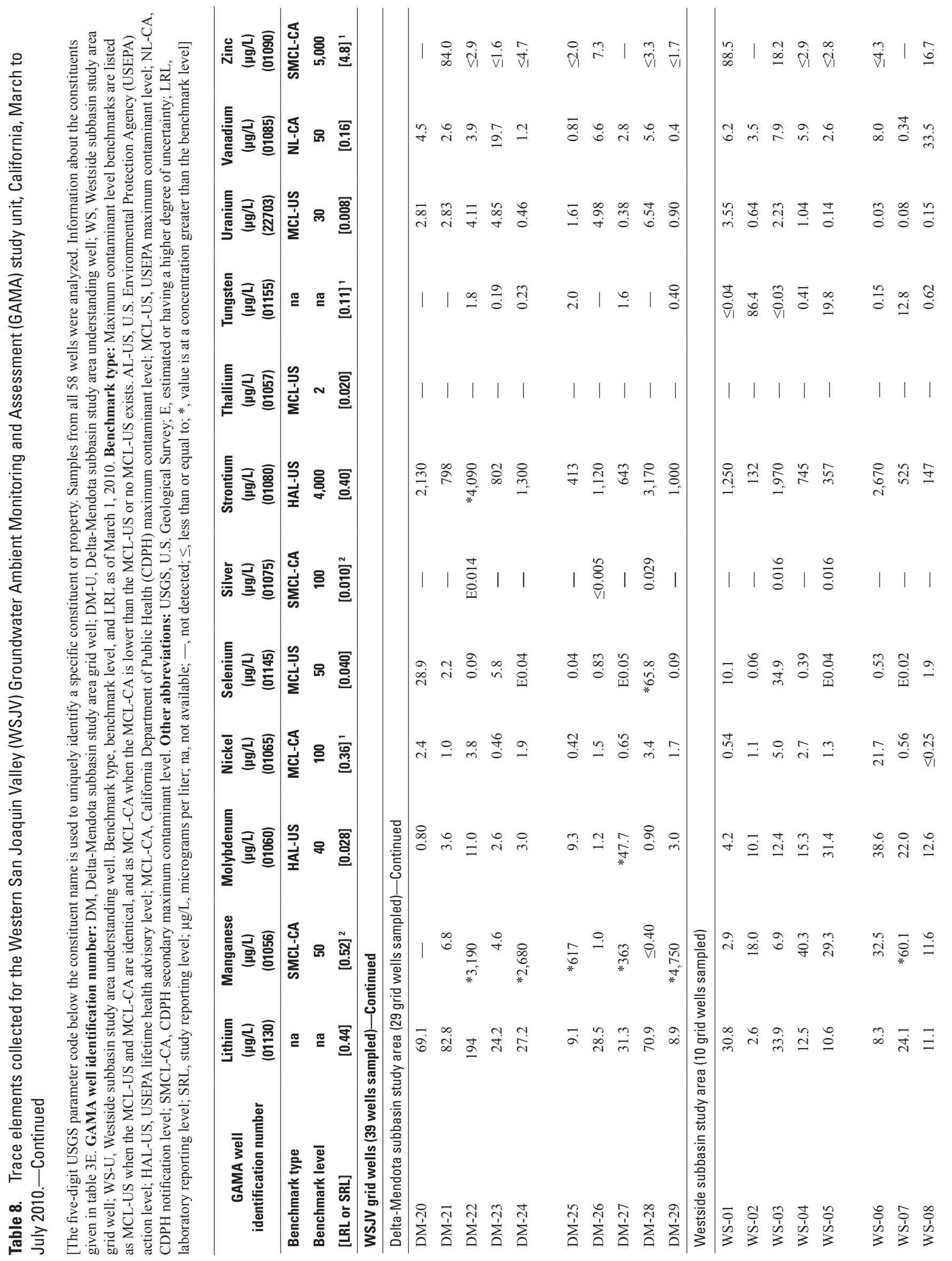




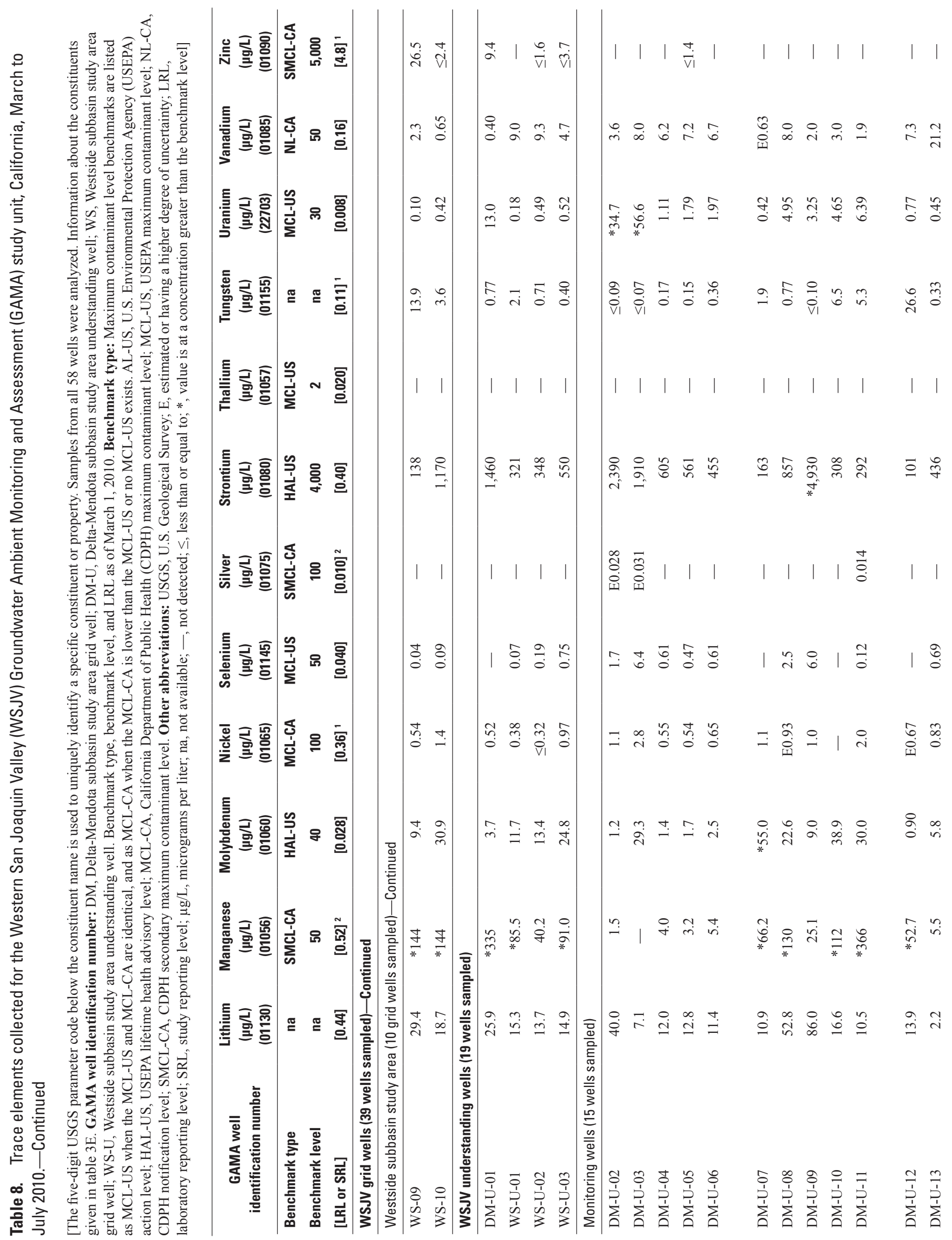




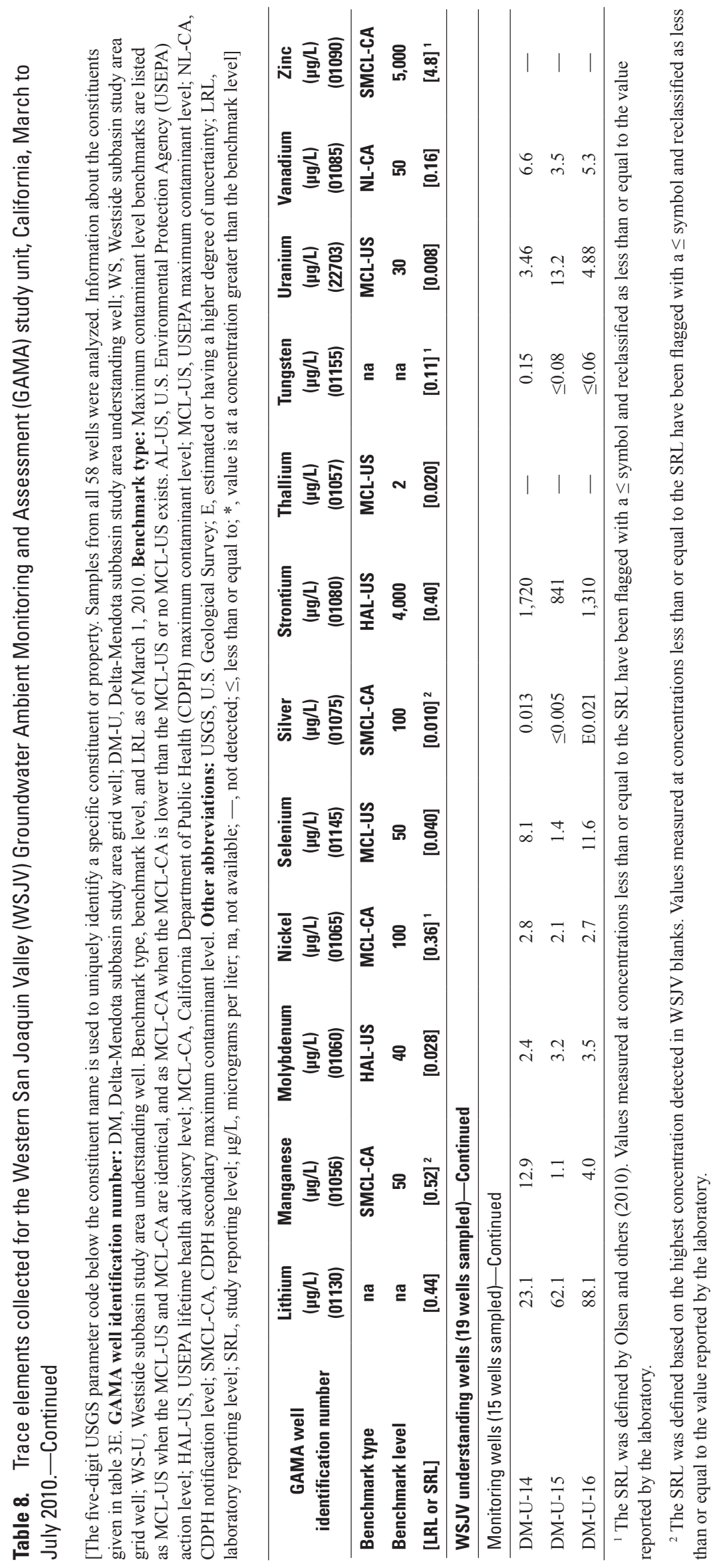


Table 9. Nutrients and dissolved organic carbon (DOC) detected in samples collected for the Western San Joaquin Valley (WSJV) Groundwater Ambient Monitoring and Assessment (GAMA) study unit, California, March to July 2010.

[The five-digit USGS parameter code below the constituent name is used to uniquely identify a specific constituent or property. Samples from all 58 wells were analyzed for nutrients. Samples from 30 wells were analyzed for DOC. Information about the constituents given in table 3F. GAMA well identification number: DM, Delta-Mendota subbasin study area grid well; DM-U, Delta-Mendota subbasin study area understanding well; WS, Westside subbasin study area grid well; WS-U, Westside subbasin study area understanding well. Benchmark type, benchmark level, and LRL as of March 1, 2010. Benchmark type: Maximum contaminant level benchmarks are listed as MCL-US when the MCL-US and MCL-CA are identical, and as MCL-CA when the MCL-CA is lower than the MCL-US or no MCL-US exists. HAL-US, U.S. Environmental Protection Agency (USEPA) lifetime health advisory level; MCL-US, USEPA maximum contaminant level. Other abbreviations: USGS, U.S. Geological Survey; E, estimated or having a higher degree of uncertainty; LRL, laboratory reporting level; SRL, study reporting level; mg/L, milligrams per liter; na, not available; - , not detected; nc, not collected; *, value is at a concentration greater than the benchmark level; $\leq$, less than or equal to; NWQL, USGS National Water Quality Laboratory]

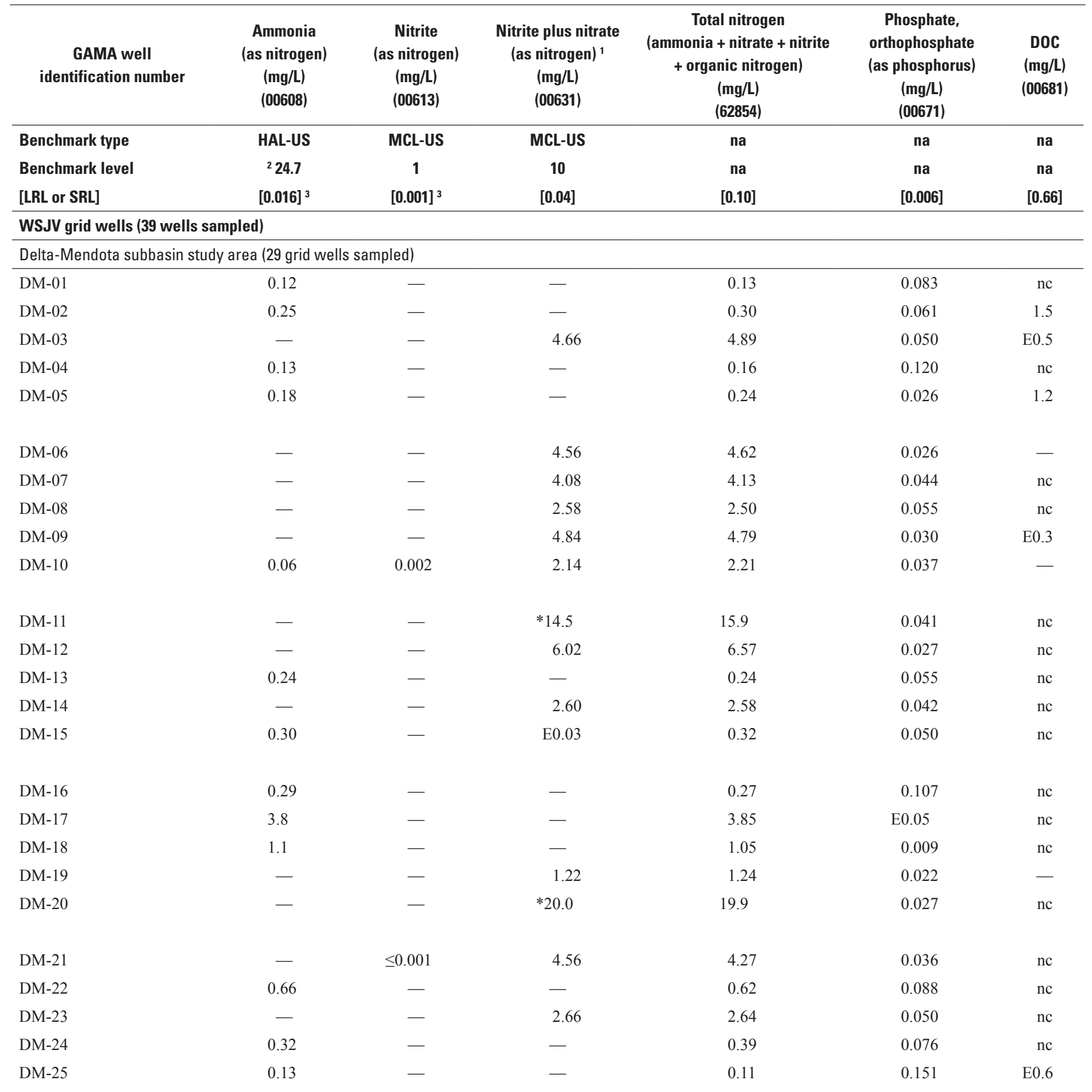


Table 9. Nutrients and dissolved organic carbon (DOC) detected in samples collected for the Western San Joaquin Valley (WSJV) Groundwater Ambient Monitoring and Assessment (GAMA) study unit, California, March to July 2010.—Continued

[The five-digit USGS parameter code below the constituent name is used to uniquely identify a specific constituent or property. Samples from all 58 wells were analyzed for nutrients. Samples from 30 wells were analyzed for DOC. Information about the constituents given in table 3F. GAMA well identification number: DM, Delta-Mendota subbasin study area grid well; DM-U, Delta-Mendota subbasin study area understanding well; WS, Westside subbasin study area grid well; WS-U, Westside subbasin study area understanding well. Benchmark type, benchmark level, and LRL as of March 1, 2010. Benchmark type: Maximum contaminant level benchmarks are listed as MCL-US when the MCL-US and MCL-CA are identical, and as MCL-CA when the MCL-CA is lower than the MCL-US or no MCL-US exists. HAL-US, U.S. Environmental Protection Agency (USEPA) lifetime health advisory level; MCL-US, USEPA maximum contaminant level. Other abbreviations: USGS, U.S. Geological Survey; E, estimated or having a higher degree of uncertainty; LRL, laboratory reporting level; SRL, study reporting level; mg/L, milligrams per liter; na, not available; —, not detected; nc, not collected; *, value is at a concentration greater than the benchmark level; $\leq$, less than or equal to; NWQL, USGS National Water Quality Laboratory]

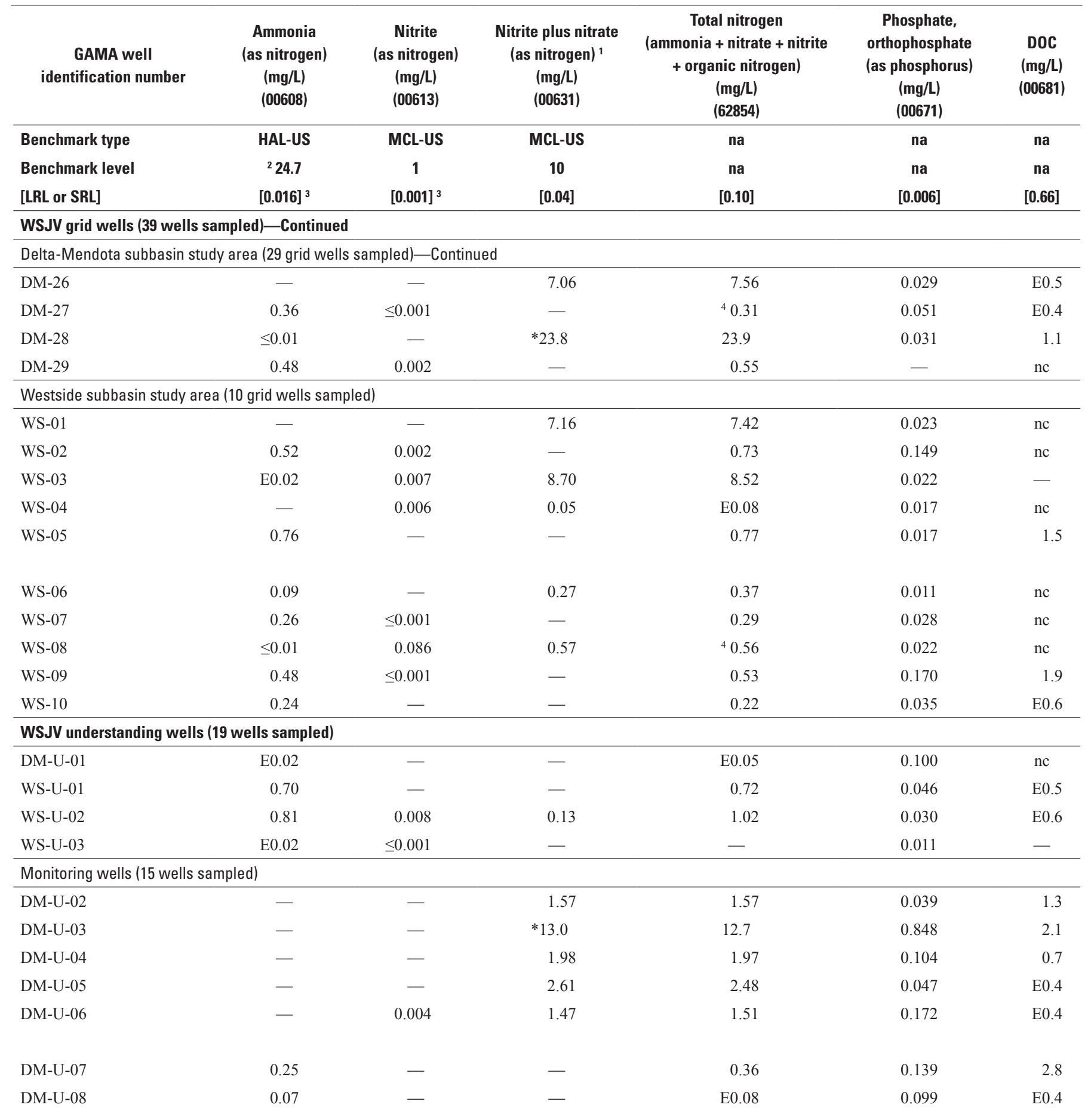


Table 9. Nutrients and dissolved organic carbon (DOC) detected in samples collected for the Western San Joaquin Valley (WSJV) Groundwater Ambient Monitoring and Assessment (GAMA) study unit, California, March to July 2010. - Continued

[The five-digit USGS parameter code below the constituent name is used to uniquely identify a specific constituent or property. Samples from all 58 wells were analyzed for nutrients. Samples from 30 wells were analyzed for DOC. Information about the constituents given in table 3F. GAMA well identification number: DM, Delta-Mendota subbasin study area grid well; DM-U, Delta-Mendota subbasin study area understanding well; WS, Westside subbasin study area grid well; WS-U, Westside subbasin study area understanding well. Benchmark type, benchmark level, and LRL as of March 1, 2010. Benchmark type: Maximum contaminant level benchmarks are listed as MCL-US when the MCL-US and MCL-CA are identical, and as MCL-CA when the MCL-CA is lower than the MCL-US or no MCL-US exists. HAL-US, U.S. Environmental Protection Agency (USEPA) lifetime health advisory level; MCL-US, USEPA maximum contaminant level. Other abbreviations: USGS, U.S. Geological Survey; E, estimated or having a higher degree of uncertainty; LRL, laboratory reporting level; SRL, study reporting level; mg/L, milligrams per liter; na, not available; - , not detected; nc, not collected; *, value is at a concentration greater than the benchmark level; $\leq$, less than or equal to; NWQL, USGS National Water Quality Laboratory]

\begin{tabular}{|c|c|c|c|c|c|c|}
\hline $\begin{array}{c}\text { GAMA well } \\
\text { identification number }\end{array}$ & $\begin{array}{c}\text { Ammonia } \\
\text { (as nitrogen) } \\
\text { (mg/L) } \\
(\mathbf{0 0 6 0 8 )}\end{array}$ & $\begin{array}{c}\text { Nitrite } \\
\text { (as nitrogen) } \\
\text { (mg/L) } \\
(\mathbf{0 0 6 1 3 )}\end{array}$ & $\begin{array}{l}\text { Nitrite plus nitrate } \\
\text { (as nitrogen) }{ }^{1} \\
(\mathrm{mg} / \mathrm{L}) \\
(00631)\end{array}$ & $\begin{array}{c}\text { Total nitrogen } \\
\text { (ammonia + nitrate + nitrite } \\
\text { + organic nitrogen) } \\
(\mathrm{mg} / \mathrm{L}) \\
(62854)\end{array}$ & $\begin{array}{c}\text { Phosphate, } \\
\text { orthophosphate } \\
\text { (as phosphorus) } \\
\text { (mg/L) } \\
\text { (00671) }\end{array}$ & $\begin{array}{c}\text { DOC } \\
(\mathrm{mg} / \mathrm{L}) \\
(00681)\end{array}$ \\
\hline Benchmark type & HAL-US & MCL-US & MCL-US & na & na & na \\
\hline Benchmark level & ${ }^{2} 24.7$ & 1 & 10 & na & na & na \\
\hline \multicolumn{7}{|c|}{ WSJV understanding wells (19 wells sampled)—Continued } \\
\hline \multicolumn{7}{|c|}{ Monitoring wells ( 15 wells sampled)_Continued } \\
\hline DM-U-09 & - & 0.002 & $* 12.7$ & 13.9 & 0.032 & - \\
\hline DM-U-10 & 0.05 & - & - & E0.07 & 0.068 & E0.5 \\
\hline DM-U-11 & 0.45 & - & - & 0.60 & 1.99 & 6.8 \\
\hline DM-U-14 & $\leq 0.01$ & 0.184 & $* 11.6$ & 11.8 & 0.023 & 7.5 \\
\hline DM-U-15 & - & 0.037 & $* 13.4$ & 13.8 & 0.088 & 0.9 \\
\hline DM-U-16 & E0.02 & 0.018 & *12.9 & 12.8 & 0.022 & E0.6 \\
\hline
\end{tabular}

${ }^{1}$ Nitrite plus nitrate, (as nitrogen) is reffered to as nitrate in the text for clarity.

${ }^{2}$ The HAL-US is $30 \mathrm{mg} / \mathrm{L}$ "as ammonia." To facilitate comparison to the analytical results, we have converted and reported this HAL-US as $24.7 \mathrm{mg} / \mathrm{L}$ "as nitrogen."

${ }^{3}$ The SRL was defined based on a detection in a WSJV blank. Values measured at concentrations less than or equal to the SRL have been flagged with a $\leq$ symbol and reclassified as less than or equal to the value reported by the laboratory.

${ }^{4}$ Total nitrogen concentrations in these samples are less than the sum of the filtered nitrogen constituents and fall outside the USGS NWQL acceptance criterion of a 10 percent relative percent difference. However, the absolute difference is $\leq 0.011 \mathrm{mg} / \mathrm{L}$, thus, the unacceptable replication is unlikely to affect interpretation of the data. 
Table 10. Major and minor ions, silica, and total dissolved solids (TDS) detected in samples collected for the Western San Joaquin Valley (WSJV) Groundwater Ambient Monitoring and Assessment (GAMA) study unit, California, March to July 2010.

[The five-digit USGS parameter code below the constituent name is used to uniquely identify a specific constituent or property. Samples from all 58 wells were analyzed. Information about the constituents given in table 3G. GAMA well identification number: DM, Delta-Mendota subbasin study area grid well; DM-U, Delta-Mendota subbasin study area understanding well; WS, Westside subbasin study area grid well; WS-U, Westside subbasin study area understanding well. Benchmark type, benchmark level, and LRL as of March 1, 2010. Benchmark type: Maximum contaminant level benchmarks are listed as MCL-US when the MCL-US and MCL-CA are identical, and as MCL-CA when the MCL-CA is lower than the MCL-US or no MCL-US exists. MCL-CA, California Department of Public Health (CDPH) maximum contaminant level; SMCL-CA, CDPH secondary maximum contaminant level. Other abbreviations: USGS, U.S. Geological Survey; LRL, laboratory reporting level; $\mathrm{mg} / \mathrm{L}$, milligrams per liter; $\mathrm{SiO}_{2}$, silicon dioxide; E, estimated or having a higher degree of uncertainty; na, not available; - , not detected; *, value is at a concentration greater than the recommended benchmark level; **, value is at a concentration greater than the upper benchmark level]

\begin{tabular}{|c|c|c|c|c|c|c|c|c|c|c|c|}
\hline $\begin{array}{c}\text { GAMA well } \\
\text { identification } \\
\text { number }\end{array}$ & $\begin{array}{c}\text { Bromide } \\
\text { (mg/L) } \\
(71870)\end{array}$ & $\begin{array}{c}\text { Calcium } \\
\text { (mg/L) } \\
(00915)\end{array}$ & $\begin{array}{c}\text { Chloride } \\
\text { (mg/L) } \\
\text { (00940) }\end{array}$ & $\begin{array}{c}\text { Fluoride } \\
\text { (mg/L) } \\
(00950)\end{array}$ & $\begin{array}{l}\text { lodide } \\
\text { (mg/L) } \\
(71865)\end{array}$ & $\begin{array}{c}\text { Magnesium } \\
\text { (mg/L) } \\
(00925)\end{array}$ & $\begin{array}{c}\text { Potassium } \\
\text { (mg/L) } \\
(00935)\end{array}$ & $\begin{array}{l}\text { Sodium } \\
\text { (mg/L) } \\
(00930)\end{array}$ & $\begin{array}{l}\text { Sulfate } \\
\text { (mg/L) } \\
(00945)\end{array}$ & $\begin{array}{c}\text { Silica } \\
\text { (as SiO }) \\
(\mathrm{mg} / \mathrm{L}) \\
(00955)\end{array}$ & $\begin{array}{c}\text { Total } \\
\text { dissolved } \\
\text { solids (TDS) } \\
\text { (mg/L) } \\
(70300)\end{array}$ \\
\hline Benchmark type & na & na & SMCL-CA & MCL-CA & na & na & na & na & SMCL-CA & na & SMCL-CA \\
\hline Benchmark level & na & na & ${ }^{1} 250(500)$ & 2 & na & na & na & na & ${ }^{1} 250(500)$ & na & ${ }^{1} 500(1,000)$ \\
\hline [LRL] & {$[0.02]$} & {$[0.044]$} & {$[0.12]$} & {$[0.08]$} & {$[0.002]$} & {$[0.016]$} & {$[0.064]$} & {$[0.10]$} & {$[0.18]$} & {$[0.058]$} & {$[10]$} \\
\hline \multicolumn{12}{|c|}{ WSJV grid wells ( 39 wells sampled) } \\
\hline \multicolumn{12}{|c|}{ Delta-Mendota subbasin study area ( 29 grid wells sampled) } \\
\hline DM-01 & 0.25 & 15.0 & 56.7 & 0.85 & 0.112 & 1.55 & 2.29 & 205 & *319 & 65.2 & *772 \\
\hline DM-02 & 0.97 & 105 & *320 & 0.18 & 0.180 & 25.6 & 5.12 & 386 & $* * 606$ & 38.0 & $* * 1,680$ \\
\hline DM-03 & 0.28 & 52.0 & 92.5 & 0.12 & 0.004 & 28.6 & 2.37 & 76.1 & 77.4 & 48.7 & *537 \\
\hline DM-04 & 0.18 & 46.9 & 79.9 & 0.10 & 0.025 & 18.3 & 1.98 & 52.8 & 42.5 & 29.5 & 397 \\
\hline DM-05 & 0.27 & 25.0 & 89.0 & - & 0.034 & 16.4 & 3.10 & 64.8 & 71.3 & 30.2 & 381 \\
\hline DM-06 & 0.63 & 88.1 & 204 & 0.24 & 0.004 & 69.6 & 1.95 & 126 & *338 & 28.4 & $* * 1,090$ \\
\hline DM-07 & 0.67 & 44.7 & 197 & 0.28 & 0.038 & 29.9 & 1.49 & 141 & 74.0 & 29.3 & $* 729$ \\
\hline DM-08 & 0.79 & 63.6 & $* 258$ & 0.36 & 0.035 & 41.0 & 1.98 & 185 & 143 & 22.6 & *959 \\
\hline DM-09 & 0.97 & 87.9 & *256 & 0.20 & 0.081 & 45.8 & 2.83 & 144 & 170 & 27.8 & *946 \\
\hline DM-10 & 1.41 & 59.9 & *326 & 0.18 & 0.340 & 34.8 & 2.32 & 255 & 225 & 27.1 & $* * 1,140$ \\
\hline DM-11 & 1.08 & 67.5 & *306 & 0.14 & 0.009 & 129 & 2.52 & 110 & 235 & 27.0 & $* * 1,130$ \\
\hline DM-12 & 0.38 & 70.5 & 105 & 0.17 & 0.005 & 26.8 & 2.04 & 118 & 210 & 26.8 & *722 \\
\hline DM-13 & 0.94 & 87.8 & $* 264$ & 0.17 & 0.293 & 43.2 & 2.92 & 179 & $* 334$ & 32.2 & $* * 1,130$ \\
\hline DM-14 & 1.19 & 158 & $* 429$ & 0.24 & 0.030 & 112 & 3.86 & 314 & $* * 737$ & 24.4 & $* * 2,130$ \\
\hline DM-15 & 0.54 & 214 & 124 & 0.18 & 0.439 & 72.6 & 3.36 & 207 & $* * 1,080$ & 32.0 & $* * 1,940$ \\
\hline DM-16 & 1.98 & 76.2 & $* * 535$ & 0.13 & 0.369 & 39.9 & 2.98 & 248 & 84.2 & 23.3 & $* * 1,100$ \\
\hline DM-17 & 3.93 & 40.9 & $* * 1,350$ & 0.45 & 2.64 & E0.04 & 5.66 & 741 & 5.33 & 65.6 & $* * 2,290$ \\
\hline DM-18 & 2.78 & 162 & $* * 846$ & 0.24 & 0.672 & 114 & 5.78 & 344 & $* * 509$ & 20.9 & $* * 2,100$ \\
\hline DM-19 & 0.59 & 83.5 & 147 & 0.34 & 0.657 & 39.6 & 1.97 & 218 & $* * 545$ & 32.6 & $* * 1,200$ \\
\hline DM-20 & 0.80 & 168 & 164 & 0.15 & 0.005 & 86.7 & 2.45 & 99.6 & $* * 555$ & 26.4 & $* * 1,300$ \\
\hline DM-21 & 0.33 & 52.9 & 107 & 0.48 & 0.012 & 46.2 & 2.51 & 142 & $* 258$ & 19.1 & $* 765$ \\
\hline DM-22 & 3.62 & 310 & $* * 1,050$ & 0.12 & 0.674 & 135 & 8.17 & 594 & $* * 1,000$ & 49.9 & $* * 3,380$ \\
\hline DM-23 & 0.24 & 41.6 & 82.0 & 0.20 & 0.021 & 26.8 & 1.85 & 90.3 & 102 & 43.3 & $* 521$ \\
\hline DM-24 & 1.04 & 101 & *390 & 0.09 & 0.093 & 57.1 & 4.08 & 220 & 213 & 33.4 & $* * 1,260$ \\
\hline DM-25 & 0.39 & 35.8 & 149 & 0.15 & 0.074 & 18.2 & 1.58 & 128 & 77.4 & 26.0 & $* 537$ \\
\hline
\end{tabular}


Table 10. Major and minor ions, silica, and total dissolved solids (TDS) detected in samples collected for the Western San Joaquin Valley (WSJV) Groundwater Ambient Monitoring and Assessment (GAMA) study unit, California, March to July 2010.—Continued

[The five-digit USGS parameter code below the constituent name is used to uniquely identify a specific constituent or property. Samples from all 58 wells were analyzed. Information about the constituents given in table 3G. GAMA well identification number: DM, Delta-Mendota subbasin study area grid well; DM-U, Delta-Mendota subbasin study area understanding well; WS, Westside subbasin study area grid well; WS-U, Westside subbasin study area understanding well. Benchmark type, benchmark level, and LRL as of March 1, 2010. Benchmark type: Maximum contaminant level benchmarks are listed as MCL-US when the MCL-US and MCL-CA are identical, and as MCL-CA when the MCL-CA is lower than the MCL-US or no MCL-US exists. MCL-CA, California Department of Public Health (CDPH) maximum contaminant level; SMCL-CA, CDPH secondary maximum contaminant level. Other abbreviations: USGS, U.S. Geological Survey; LRL, laboratory reporting level; $\mathrm{mg} / \mathrm{L}$, milligrams per liter; $\mathrm{SiO}_{2}$, silicon dioxide; E, estimated or having a higher degree of uncertainty; na, not available; - , not detected; *, value is at a concentration greater than the recommended benchmark level; **, value is at a concentration greater than the upper benchmark level]

\begin{tabular}{|c|c|c|c|c|c|c|c|c|c|c|c|}
\hline $\begin{array}{c}\text { GAMA well } \\
\text { identification } \\
\text { number }\end{array}$ & $\begin{array}{c}\text { Bromide } \\
\text { (mg/L) } \\
(71870)\end{array}$ & $\begin{array}{c}\text { Calcium } \\
\text { (mg/L) } \\
(00915)\end{array}$ & $\begin{array}{c}\text { Chloride } \\
\text { (mg/L) } \\
(00940)\end{array}$ & $\begin{array}{c}\text { Fluoride } \\
\text { (mg/L) } \\
(00950)\end{array}$ & $\begin{array}{l}\text { lodide } \\
\text { (mg/L) } \\
(71865)\end{array}$ & $\begin{array}{c}\text { Magnesium } \\
\text { (mg/L) } \\
(00925)\end{array}$ & $\begin{array}{c}\text { Potassium } \\
\text { (mg/L) } \\
(00935)\end{array}$ & $\begin{array}{c}\text { Sodium } \\
\text { (mg/L) } \\
(00930)\end{array}$ & $\begin{array}{l}\text { Sulfate } \\
\text { (mg/L) } \\
(00945)\end{array}$ & $\begin{array}{c}\text { Silica } \\
\text { (as SiO }) \\
(\mathrm{mg} / \mathrm{L}) \\
(00955)\end{array}$ & $\begin{array}{c}\text { Total } \\
\text { dissolved } \\
\text { solids (TDS) } \\
(\mathrm{mg} / \mathrm{L}) \\
(70300) \\
\end{array}$ \\
\hline Benchmark type & na & na & SMCL-CA & MCL-CA & na & na & na & na & SMCL-CA & na & SMCL-CA \\
\hline Benchmark level & na & na & ${ }^{1} 250(500)$ & 2 & na & na & na & na & ${ }^{1} 250(500)$ & na & ${ }^{1} 500(1,000)$ \\
\hline [LRL] & {$[0.02]$} & {$[0.044]$} & {$[0.12]$} & {$[0.08]$} & {$[0.002]$} & {$[0.016]$} & {$[0.064]$} & [0.10] & {$[0.18]$} & {$[0.058]$} & [10] \\
\hline \multicolumn{12}{|c|}{ WSJV grid wells (39 wells sampled)—Continued } \\
\hline \multicolumn{12}{|c|}{ Delta-Mendota subbasin study area ( 29 grid wells sampled)—Continued } \\
\hline DM-26 & 0.43 & 88.5 & 136 & 0.28 & 0.018 & 47.8 & 1.59 & 99.0 & 139 & 25.4 & *764 \\
\hline DM-27 & 1.82 & 51.7 & *473 & 0.22 & 0.400 & 18.4 & 3.27 & 535 & **610 & 29.3 & $* * 1,770$ \\
\hline DM-28 & 2.20 & 220 & $* * 600$ & 0.17 & & 141 & 3.02 & 444 & **918 & 24.2 & $* * 2,750$ \\
\hline DM-29 & 0.63 & 114 & 235 & 0.13 & 0.063 & 42.3 & 3.31 & 151 & 216 & 27.0 & *966 \\
\hline \multicolumn{12}{|c|}{ Westside subbasin study area (10 grid wells sampled) } \\
\hline WS-01 & 0.45 & 94.8 & 96.2 & 0.23 & - & 52.1 & 2.55 & 137 & *492 & 34.2 & $* * 1,110$ \\
\hline WS-02 & 0.23 & 11.1 & 47.7 & 0.99 & 0.165 & 1.28 & 1.13 & 160 & 8.33 & 23.3 & 470 \\
\hline WS-03 & 0.50 & 134 & 111 & 0.18 & 0.081 & 52.9 & 2.02 & 188 & $* * 706$ & 24.4 & $* * 1,360$ \\
\hline WS-04 & 0.21 & 85.5 & 56.9 & 0.27 & 0.194 & 8.82 & 1.30 & 195 & $* * 533$ & 18.5 & *954 \\
\hline WS-05 & 1.15 & 38.4 & 250 & 0.49 & 0.375 & 0.97 & 1.09 & 287 & *312 & 17.6 & *991 \\
\hline WS-06 & 0.29 & 570 & 89.3 & 0.26 & 0.290 & 3.55 & 1.62 & 201 & $* * 1,730$ & 12.3 & $* * 2,780$ \\
\hline WS-07 & 0.15 & 65.1 & 39.0 & 0.29 & 0.095 & 9.78 & 1.83 & 200 & $* 487$ & 26.6 & *909 \\
\hline WS-08 & 0.14 & 22.6 & 27.3 & 0.22 & 0.029 & 1.83 & 1.07 & 153 & $* 291$ & 30.9 & $* 569$ \\
\hline WS-09 & 0.46 & 16.8 & 95.8 & 0.53 & 0.236 & 2.63 & 2.17 & 203 & 162 & 59.5 & *672 \\
\hline WS-10 & 0.26 & 173 & 75.5 & 0.20 & 0.219 & 19.6 & 1.95 & 268 & $* * 817$ & 26.2 & $* * 1,480$ \\
\hline \multicolumn{12}{|c|}{ WSJV understanding wells (19 wells sampled) } \\
\hline DM-U-01 & 0.41 & 85.7 & 194 & 0.18 & 0.162 & 54.1 & 2.15 & 110 & *264 & 37.3 & *911 \\
\hline WS-U-01 & 1.53 & 37.9 & *319 & 0.10 & 0.491 & 4.87 & 1.05 & 259 & 111 & 28.6 & $* 855$ \\
\hline WS-U-02 & 0.97 & 31.7 & 188 & 0.16 & 0.224 & 5.50 & 1.06 & 198 & 207 & 27.3 & *805 \\
\hline WS-U-03 & 0.34 & 72.2 & 93.0 & 0.14 & 0.102 & 19.7 & 2.80 & 276 & $* * 634$ & 11.5 & $* * 1,140$ \\
\hline \multicolumn{12}{|c|}{ Monitoring wells ( 15 wells sampled) } \\
\hline DM-U-02 & 1.35 & 127 & $* 429$ & 0.20 & 0.128 & 129 & 3.22 & 321 & $* * 696$ & 25.1 & $* * 2,110$ \\
\hline DM-U-03 & 1.57 & 164 & $* 467$ & 0.27 & 0.025 & 131 & 2.95 & 331 & $* * 802$ & 21.9 & $* * 2,300$ \\
\hline DM-U-04 & 0.23 & 46.6 & 63.1 & 0.24 & 0.007 & 28.0 & 2.60 & 47.9 & 75.1 & 37.3 & 432 \\
\hline DM-U-05 & 0.29 & 51.3 & 79.9 & 0.20 & 0.006 & 24.3 & 2.27 & 57.2 & 62.9 & 31.8 & 430 \\
\hline DM-U-06 & 0.18 & 42.6 & 47.1 & 0.21 & 0.010 & 20.2 & 2.99 & 55.7 & 67.7 & 29.2 & 392 \\
\hline DM-U-07 & 0.53 & 15.5 & 112 & 0.26 & 0.499 & 2.72 & 1.14 & 302 & *316 & 29.8 & $* * 1,020$ \\
\hline DM-U-08 & 0.90 & 47.9 & *256 & 0.36 & 1.95 & 18.1 & 2.81 & 217 & 152 & 41.1 & *827 \\
\hline
\end{tabular}


Table 10. Major and minor ions, silica, and total dissolved solids (TDS) detected in samples collected for the Western San Joaquin Valley (WSJV) Groundwater Ambient Monitoring and Assessment (GAMA) study unit, California, March to July 2010.—Continued

[The five-digit USGS parameter code below the constituent name is used to uniquely identify a specific constituent or property. Samples from all 58 wells were analyzed. Information about the constituents given in table 3G. GAMA well identification number: DM, Delta-Mendota subbasin study area grid well; DM-U, Delta-Mendota subbasin study area understanding well; WS, Westside subbasin study area grid well; WS-U, Westside subbasin study area understanding well. Benchmark type, benchmark level, and LRL as of March 1, 2010. Benchmark type: Maximum contaminant level benchmarks are listed as MCL-US when the MCL-US and MCL-CA are identical, and as MCL-CA when the MCL-CA is lower than the MCL-US or no MCL-US exists. MCL-CA, California Department of Public Health (CDPH) maximum contaminant level; SMCL-CA, CDPH secondary maximum contaminant level. Other abbreviations: USGS, U.S. Geological Survey; LRL, laboratory reporting level; $\mathrm{mg} / \mathrm{L}$, milligrams per liter; $\mathrm{SiO}_{2}$, silicon dioxide; E, estimated or having a higher degree of uncertainty; na, not available; - , not detected; *, value is at a concentration greater than the recommended benchmark level; **, value is at a concentration greater than the upper benchmark level]

\begin{tabular}{|c|c|c|c|c|c|c|c|c|c|c|c|}
\hline $\begin{array}{c}\text { GAMA well } \\
\text { identification } \\
\text { number }\end{array}$ & $\begin{array}{c}\text { Bromide } \\
\text { (mg/L) } \\
(71870)\end{array}$ & $\begin{array}{c}\text { Calcium } \\
\text { (mg/L) } \\
(00915)\end{array}$ & $\begin{array}{c}\text { Chloride } \\
\text { (mg/L) } \\
(00940)\end{array}$ & $\begin{array}{c}\text { Fluoride } \\
\text { (mg/L) } \\
(00950)\end{array}$ & $\begin{array}{l}\text { lodide } \\
\text { (mg/L) } \\
(71865)\end{array}$ & $\begin{array}{c}\text { Magnesium } \\
(\mathrm{mg} / \mathrm{L}) \\
(00925)\end{array}$ & $\begin{array}{c}\text { Potassium } \\
\text { (mg/L) } \\
(00935)\end{array}$ & $\begin{array}{l}\text { Sodium } \\
\text { (mg/L) } \\
(00930)\end{array}$ & $\begin{array}{l}\text { Sulfate } \\
\text { (mg/L) } \\
(00945)\end{array}$ & $\begin{array}{c}\text { Silica } \\
\left(\text { as } \mathrm{SiO}_{2}\right) \\
(\mathrm{mg} / \mathrm{L}) \\
(00955)\end{array}$ & $\begin{array}{c}\text { Total } \\
\text { dissolved } \\
\text { solids (TDS) } \\
(\mathrm{mg} / \mathrm{L}) \\
(70300)\end{array}$ \\
\hline Benchmark type & na & na & SMCL-CA & MCL-CA & na & na & na & na & SMCL-CA & na & SMCL-CA \\
\hline Benchmark level & na & na & ${ }^{1} 250(500)$ & 2 & na & na & na & na & $1250(500)$ & na & $1500(1,000)$ \\
\hline \multicolumn{12}{|c|}{ Monitoring wells ( 15 wells sampled)_Continued } \\
\hline DM-U-09 & 1.13 & 240 & $* 322$ & 0.24 & 1.13 & 89.3 & 2.59 & 223 & $* * 916$ & 31.8 & $* * 2,050$ \\
\hline DM-U-10 & 1.77 & 34.4 & $* 453$ & 0.48 & 0.411 & 4.13 & 2.75 & 462 & $* 474$ & 24.0 & $* * 1,650$ \\
\hline DM-U-11 & 0.32 & 33.9 & 96.4 & 0.40 & 0.074 & 13.1 & 4.51 & 136 & 81.7 & 20.9 & $* 568$ \\
\hline DM-U-14 & 0.53 & 87.7 & 118 & 0.17 & 0.020 & 55.1 & 3.28 & 109 & *296 & 24.8 & *907 \\
\hline DM-U-15 & 0.27 & 64.1 & 62.0 & 0.53 & 0.006 & 29.2 & 1.05 & 87.0 & 121 & 25.2 & *593 \\
\hline DM-U-16 & 0.74 & 100 & 135 & 0.52 & 0.006 & 62.2 & 2.19 & 142 & $* 422$ & 25.6 & $* * 1,070$ \\
\hline
\end{tabular}

${ }^{1}$ The SMCL-CA benchmarks for chloride, sulfate, and TDS have recommended and upper benchmark levels. The upper benchmark level is shown in parentheses. 
Table 11. Total arsenic and iron (unfiltered) and arsenic, chromium, and iron species (filtered) detected in samples collected for the Western San Joaquin Valley Groundwater Ambient Monitoring and Assessment (GAMA) study unit, California, March to June 2010.

[The five-digit USGS parameter code is used to uniquely identify a specific constituent or property. Information about the constituents given in table $3 \mathrm{H}$. Samples for total arsenic and iron (unfiltered) and arsenic and iron species (filtered) were collected at all 58 wells. Samples for chromium species were collected at 33 slow wells. GAMA well identification number: DM, Delta-Mendota subbasin study area grid well; DM-U, Delta-Mendota subbasin study area understanding well; WS, Westside subbasin study area grid well; WS-U, Westside subbasin study area understanding well. Benchmark type, benchmark level, and MDL as of March 1, 2010. Benchmark type: Maximum contaminant level benchmarks are listed as MCL-US when the MCL-US and MCL-CA are identical, and as MCL-CA when the MCL-CA is lower than the MCL-US or no MCL-US exists. MCL-CA, California Department of Public Health (CDPH) maximum contaminant level; MCL-US, U.S. Environmental Protection Agency maximum contaminant level; SMCL-CA, CDPH secondary maximum contaminant level. Other abbreviations: USGS, U.S. Geological Survey; MDL, method detection limit; na, not available; $\mu \mathrm{g} / \mathrm{L}$, micrograms per liter; *, value is at a concentration greater than the benchmark level; nc, not collected; - , not detected; NWQL, National Water Quality Laboratory]

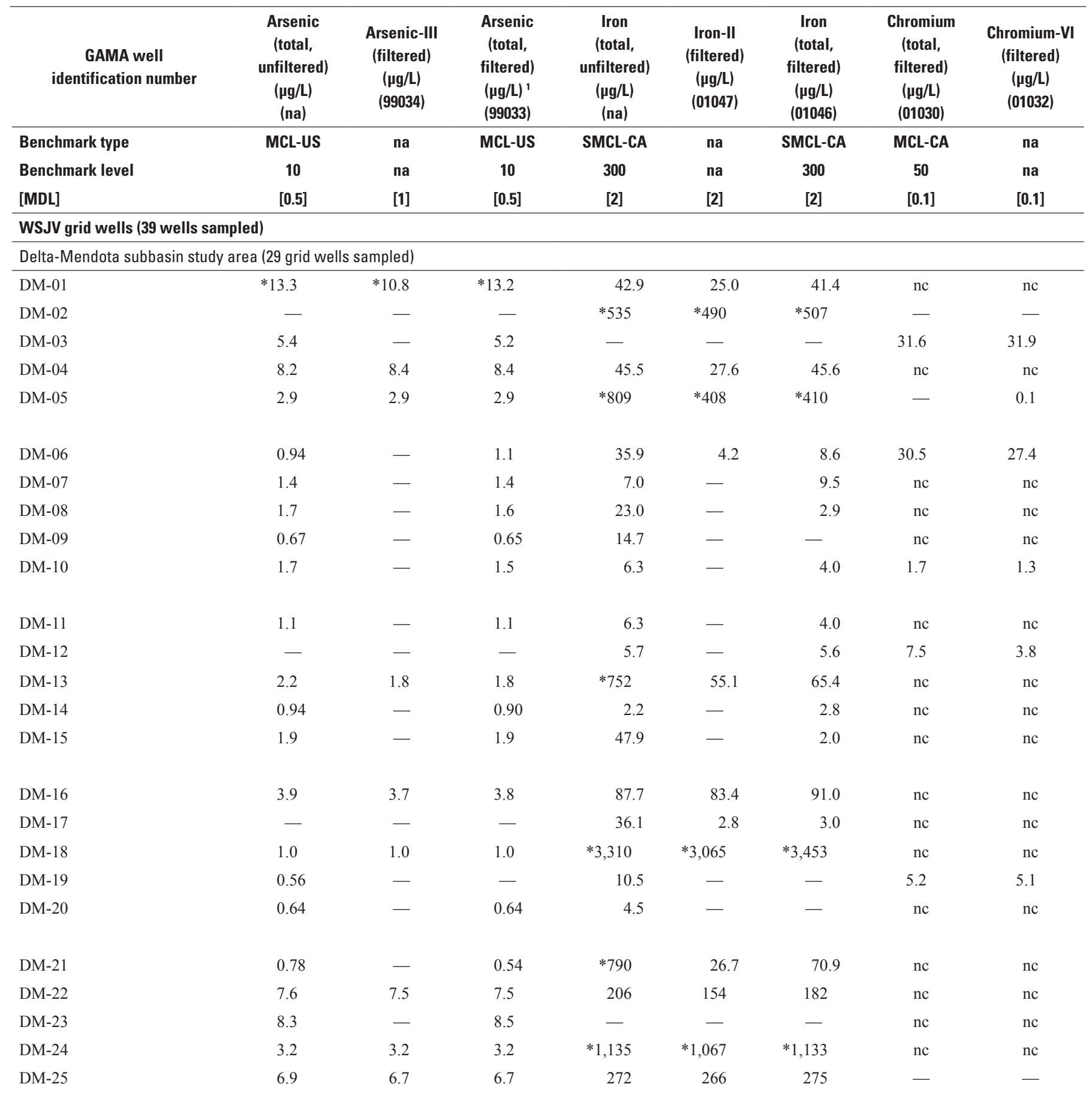


Table 11. Total arsenic and iron (unfiltered) and arsenic, chromium, and iron species (filtered) detected in samples collected for the Western San Joaquin Valley Groundwater Ambient Monitoring and Assessment (GAMA) study unit, California, March to June 2010.-Continued

[The five-digit USGS parameter code is used to uniquely identify a specific constituent or property. Information about the constituents given in table $3 \mathrm{H}$. Samples for total arsenic and iron (unfiltered) and arsenic and iron species (filtered) were collected at all 58 wells. Samples for chromium species were collected at 33 slow wells. GAMA well identification number: DM, Delta-Mendota subbasin study area grid well; DM-U, Delta-Mendota subbasin study area understanding well; WS, Westside subbasin study area grid well; WS-U, Westside subbasin study area understanding well. Benchmark type, benchmark level, and MDL as of March 1, 2010. Benchmark type: Maximum contaminant level benchmarks are listed as MCL-US when the MCL-US and MCL-CA are identical, and as MCL-CA when the MCL-CA is lower than the MCL-US or no MCL-US exists. MCL-CA, California Department of Public Health (CDPH) maximum contaminant level; MCL-US, U.S. Environmental Protection Agency maximum contaminant level; SMCL-CA, CDPH secondary maximum contaminant level. Other abbreviations: USGS, U.S. Geological Survey; MDL, method detection limit; na, not available; $\mu \mathrm{g} / \mathrm{L}$, micrograms per liter; *, value is at a concentration greater than the benchmark level; nc, not collected; - , not detected; NWQL, National Water Quality Laboratory]

\begin{tabular}{|c|c|c|c|c|c|c|c|c|}
\hline $\begin{array}{c}\text { GAMA well } \\
\text { identification number }\end{array}$ & $\begin{array}{c}\text { Arsenic } \\
\text { (total, } \\
\text { unfiltered) } \\
\text { ( } \mu \mathrm{g} / \mathrm{L}) \\
\text { (na) }\end{array}$ & $\begin{array}{c}\text { Arsenic-III } \\
\text { (filtered) } \\
(\mu \mathrm{g} / \mathrm{L}) \\
(99034)\end{array}$ & $\begin{array}{c}\text { Arsenic } \\
\text { (total, } \\
\text { filtered) } \\
(\mu \mathrm{g} / \mathrm{L})^{1} \\
(99033)\end{array}$ & $\begin{array}{c}\text { Iron } \\
\text { (total, } \\
\text { unfiltered) } \\
\text { ( } \mathrm{\mu g} / \mathrm{L}) \\
\text { (na) }\end{array}$ & $\begin{array}{c}\text { Iron-II } \\
\text { (filtered) } \\
(\mu \mathrm{g} / \mathrm{L}) \\
(01047)\end{array}$ & $\begin{array}{c}\text { Iron } \\
\text { (total, } \\
\text { filtered) } \\
(\mu \mathrm{g} / \mathrm{L}) \\
(01046)\end{array}$ & $\begin{array}{c}\text { Chromium } \\
\text { (total, } \\
\text { filtered) } \\
(\mu \mathrm{g} / \mathrm{L}) \\
(01030)\end{array}$ & $\begin{array}{c}\text { Chromium-VI } \\
\text { (filtered) } \\
(\mu \mathrm{g} / \mathrm{L}) \\
(01032)\end{array}$ \\
\hline Benchmark type & MCL-US & na & MCL-US & SMCL-CA & na & SMCL-CA & MCL-CA & na \\
\hline Benchmark level & 10 & na & 10 & 300 & na & 300 & 50 & na \\
\hline [MDL] & {$[0.5]$} & [1] & {$[0.5]$} & [2] & [2] & [2] & [0.1] & [0.1] \\
\hline \multicolumn{9}{|c|}{ WSJV grid wells ( 39 wells sampled)—Continued } \\
\hline \multicolumn{9}{|c|}{ Delta-Mendota subbasin study area ( 29 grid wells sampled)—Continued } \\
\hline DM-26 & 0.86 & - & 0.87 & 8.0 & - & 7.4 & 13.4 & 12.1 \\
\hline DM-27 & 6.7 & 4.8 & 6.5 & 81.5 & 16.8 & 68.0 & - & - \\
\hline DM-28 & - & - & - & 12.0 & - & 11.0 & 23.2 & 17.0 \\
\hline DM-29 & *14.5 & *14.2 & *14.2 & $* 11,700$ & $* 10,900$ & $* 11,200$ & $\mathrm{nc}$ & $\mathrm{nc}$ \\
\hline \multicolumn{9}{|c|}{ Westside subbasin study area (10 grid wells sampled) } \\
\hline WS-01 & 0.89 & - & 0.80 & 141 & 4.9 & 26.4 & $\mathrm{nc}$ & $\mathrm{nc}$ \\
\hline WS-02 & - & - & - & 10.3 & - & - & $\mathrm{nc}$ & $\mathrm{nc}$ \\
\hline WS-03 & 1.0 & - & 1.0 & 159 & - & 3.0 & - & - \\
\hline WS-04 & 1.9 & - & 1.9 & 79.6 & 14.6 & 62.1 & $\mathrm{nc}$ & $\mathrm{nc}$ \\
\hline WS-05 & 4.0 & - & 3.9 & 14.6 & 6.9 & 6.5 & - & - \\
\hline WS-06 & 1.7 & - & 1.8 & 24.8 & - & 4.0 & $\mathrm{nc}$ & $\mathrm{nc}$ \\
\hline WS-07 & 2.6 & 2.6 & 2.6 & 41.8 & 35.5 & 43.2 & $\mathrm{nc}$ & $\mathrm{nc}$ \\
\hline WS- 08 & 7.7 & - & 7.5 & *326 & 19.1 & 41.3 & $\mathrm{nc}$ & $\mathrm{nc}$ \\
\hline WS-09 & 0.66 & - & 0.64 & 2.4 & 85.9 & 87.9 & 0.10 & - \\
\hline WS-10 & 3.2 & 2.0 & 3.2 & 36.0 & 23.8 & 24.3 & 0.40 & - \\
\hline \multicolumn{9}{|c|}{ WSJV understanding wells (19 wells sampled) } \\
\hline DM-U-01 & $* 12.8$ & 7.6 & $* 12.6$ & 143 & 111 & 126 & $\mathrm{nc}$ & $\mathrm{nc}$ \\
\hline WS-U-01 & $* 12.4$ & *11.6 & $* 12.5^{2}$ & 23.8 & 20.9 & 20.8 & - & - \\
\hline WS-U-02 & *10.2 & - & $* 10.4$ & 7.5 & 4.2 & 6.1 & 1.0 & 0.29 \\
\hline WS-U-03 & 3.5 & 2.3 & 3.2 & 277 & 16.2 & 45.1 & - & - \\
\hline \multicolumn{9}{|c|}{ Monitoring wells ( 15 wells sampled) } \\
\hline DM-U-02 & 0.79 & - & 0.73 & 56.9 & - & 2.1 & 15.0 & 15.0 \\
\hline DM-U-03 & 2.7 & - & 2.7 & 3.9 & - & - & 6.1 & 5.2 \\
\hline DM-U-04 & 6.5 & - & 4.3 & 10.8 & 3.1 & - & 0.92 & 0.77 \\
\hline DM-U-05 & 6.4 & - & 6.2 & 4.4 & - & - & 5.4 & 5.2 \\
\hline DM-U-06 & 8.0 & - & 8.4 & 13.2 & - & - & 1.8 & 1.3 \\
\hline DM-U-07 & $* 12.5$ & $* 11.7$ & $* 11.7$ & 6.0 & - & - & 0.48 & 0.55 \\
\hline DM-U-08 & 6.6 & 5.8 & 6.4 & 58.1 & - & 5.9 & 0.42 & 0.17 \\
\hline
\end{tabular}


Table 11. Total arsenic and iron (unfiltered) and arsenic, chromium, and iron species (filtered) detected in samples collected for the Western San Joaquin Valley Groundwater Ambient Monitoring and Assessment (GAMA) study unit, California, March to June 2010.-Continued

[The five-digit USGS parameter code is used to uniquely identify a specific constituent or property. Information about the constituents given in table $3 \mathrm{H}$. Samples for total arsenic and iron (unfiltered) and arsenic and iron species (filtered) were collected at all 58 wells. Samples for chromium species were collected at 33 slow wells. GAMA well identification number: DM, Delta-Mendota subbasin study area grid well; DM-U, Delta-Mendota subbasin study area understanding well; WS, Westside subbasin study area grid well; WS-U, Westside subbasin study area understanding well. Benchmark type, benchmark level, and MDL as of March 1, 2010. Benchmark type: Maximum contaminant level benchmarks are listed as MCL-US when the MCL-US and MCL-CA are identical, and as MCL-CA when the MCL-CA is lower than the MCL-US or no MCL-US exists. MCL-CA, California Department of Public Health (CDPH) maximum contaminant level; MCL-US, U.S. Environmental Protection Agency maximum contaminant level; SMCL-CA, CDPH secondary maximum contaminant level. Other abbreviations: USGS, U.S. Geological Survey; MDL, method detection limit; na, not available; $\mu \mathrm{g} / \mathrm{L}$, micrograms per liter; *, value is at a concentration greater than the benchmark level; nc, not collected; —, not detected; NWQL, National Water Quality Laboratory]

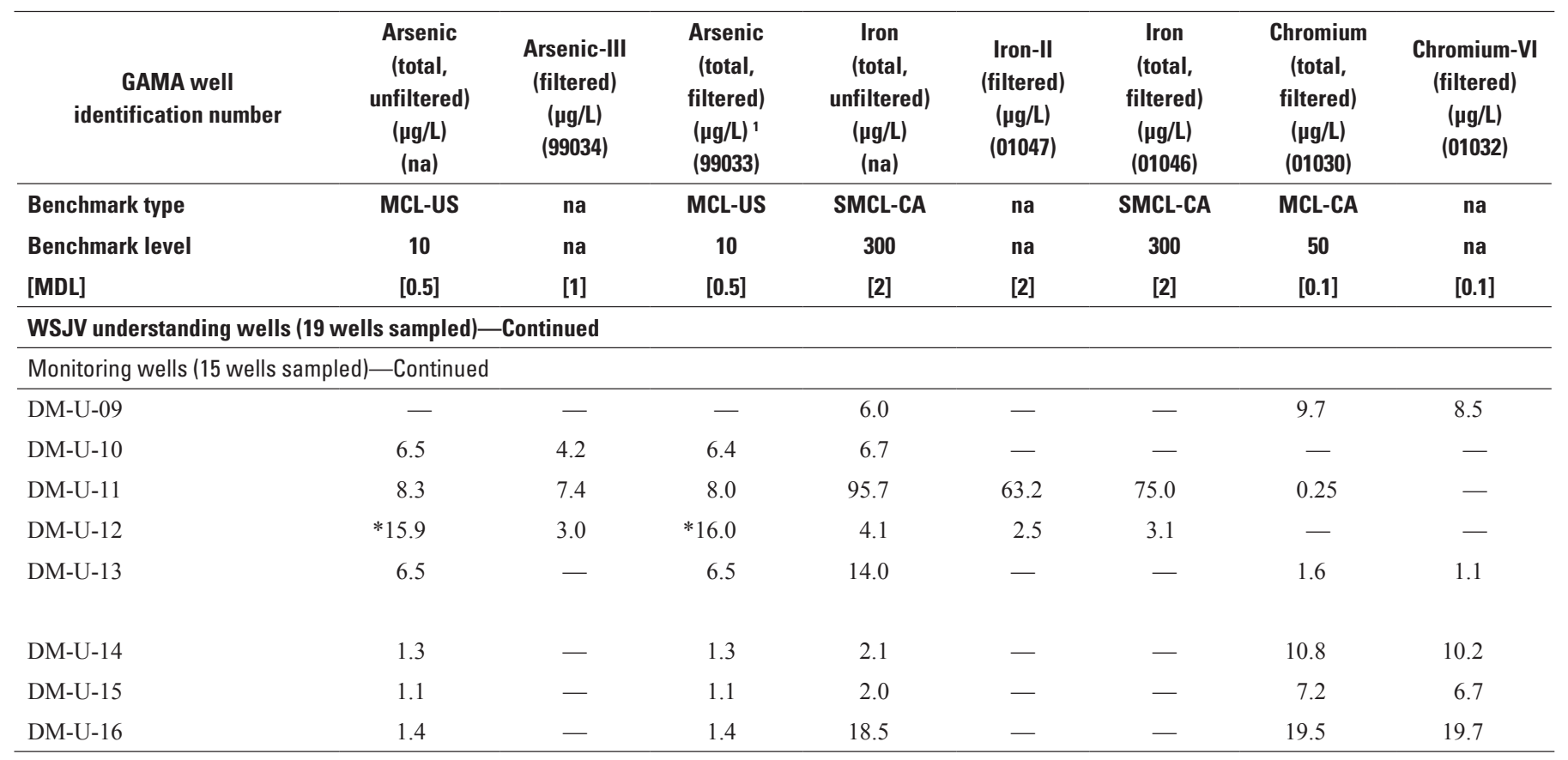

${ }^{1}$ Reported values are for filtered samples acidified with hydrochloric acid $(\mathrm{HCl})$. Filtered unacidified samples also were collected and analyzed for comparison with the acidified samples because of potential concerns about arsenic loss under sulfate-reducing conditions in some cases using the HCl-preservation method (Planer-Friedrich and others, 2007). However, unless otherwise noted, all $\mathrm{HCl}$-preserved samples had higher arsenic concentrations than unacidified samples and values closer to those measured by the USGS NWQL in filtered samples preserved with nitric acid.

${ }^{2}$ Arsenic concentration measured in a filtered unacidified sample was $15.0 \mu \mathrm{g} / \mathrm{L}$. 


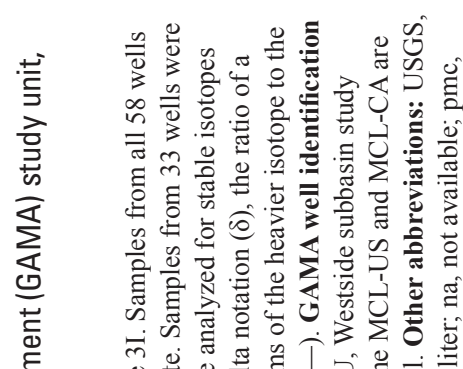

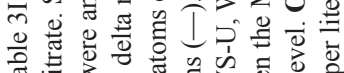

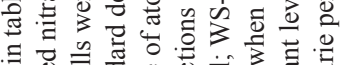

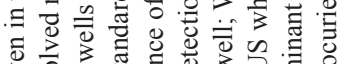
क人

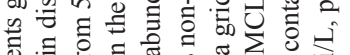

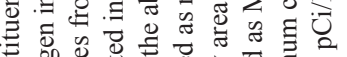

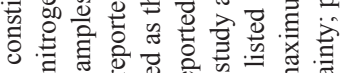

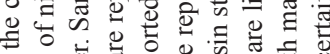

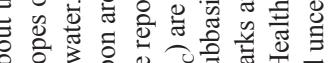

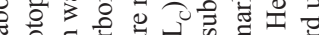
.

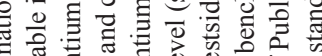
के

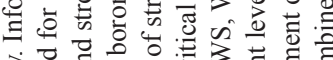

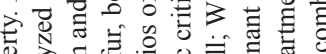

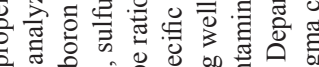

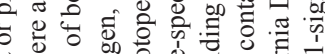

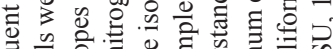

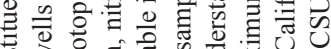

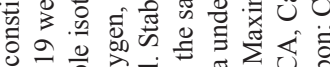

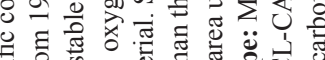

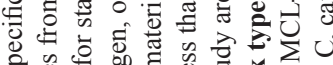
की त :

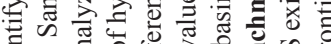
एँ

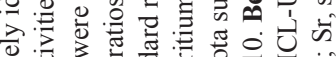

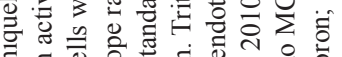

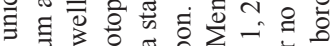

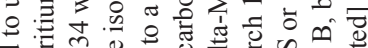
ठ

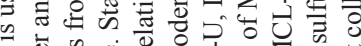
a d ए

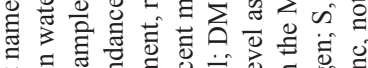

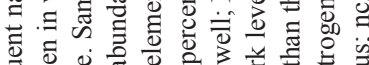

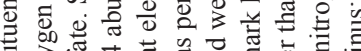

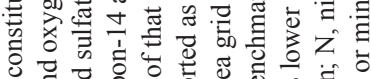

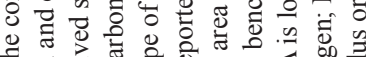

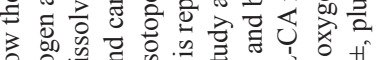

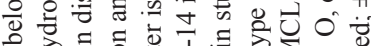

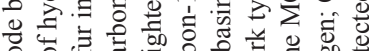

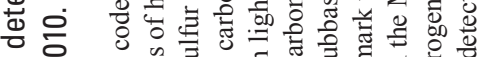

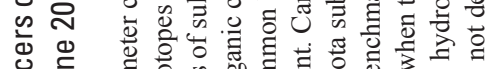

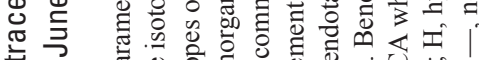

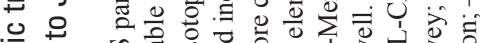

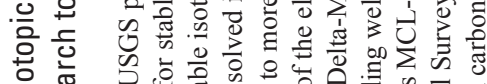

象 $\sum^{\pi}$

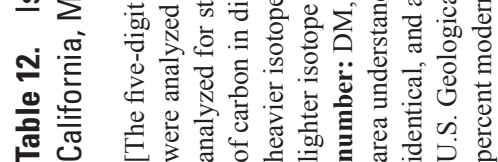

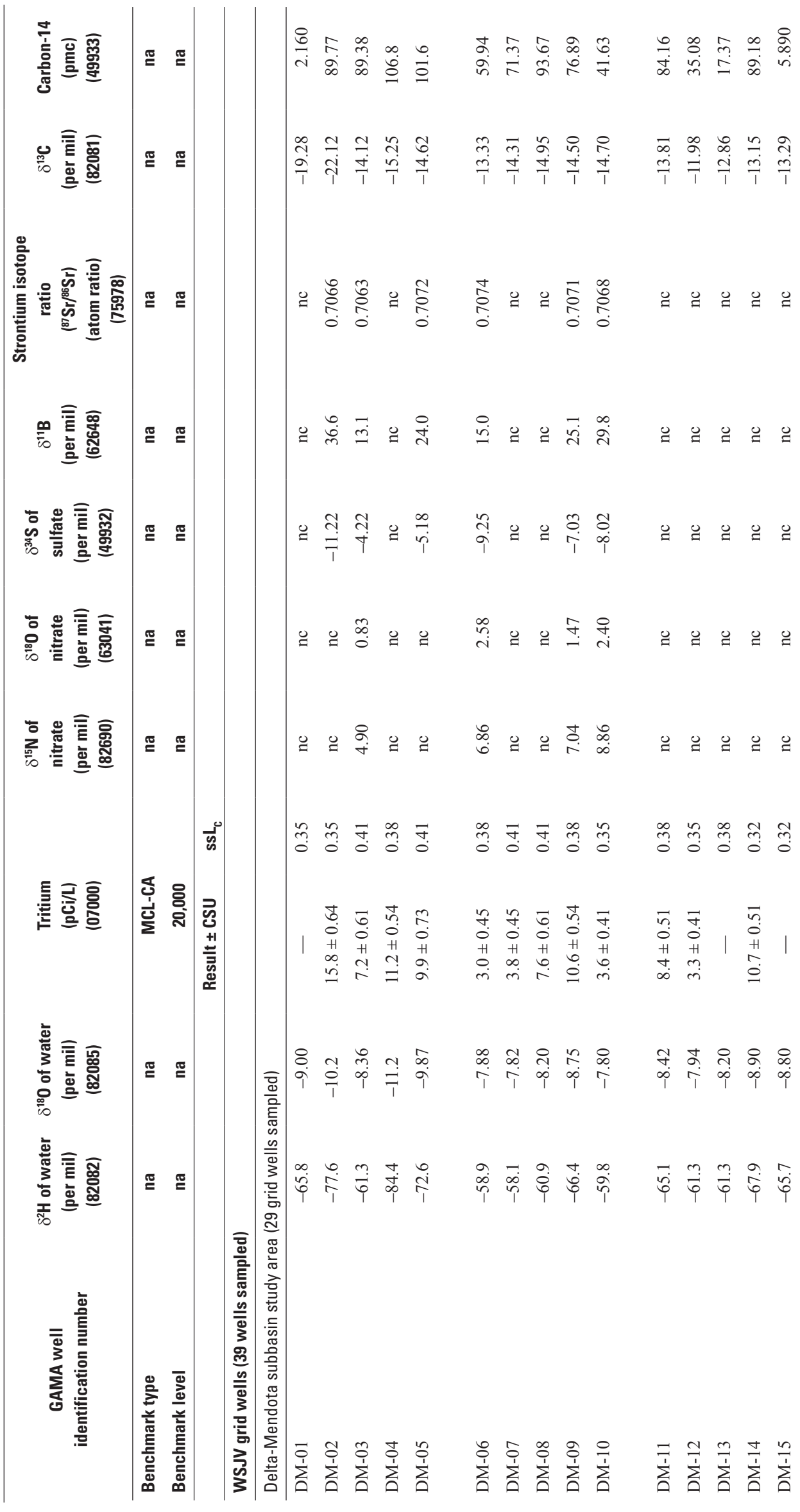




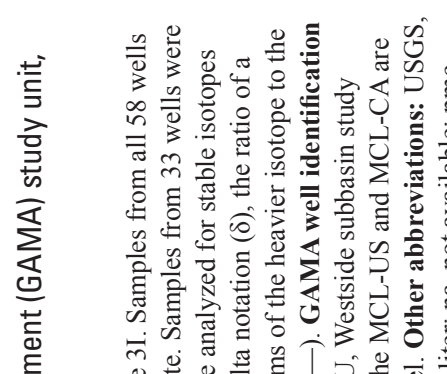

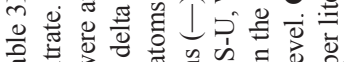

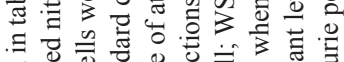

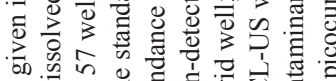

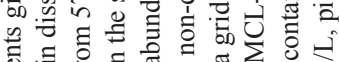

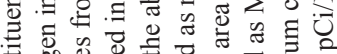

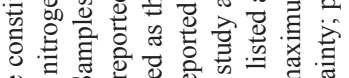

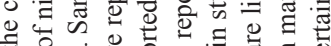

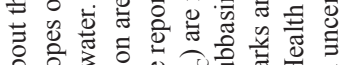

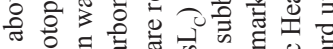

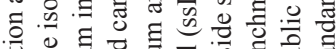

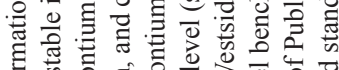

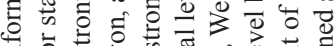

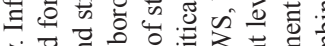

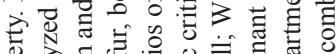

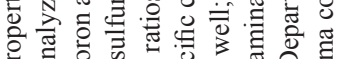

类频

\pm क

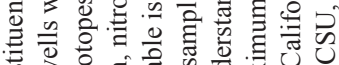

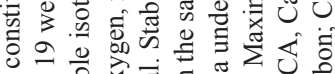

\%े

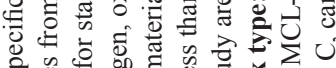

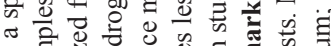

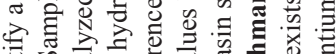

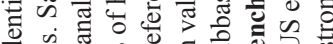

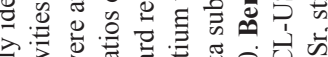

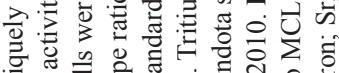

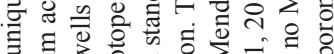

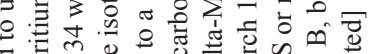

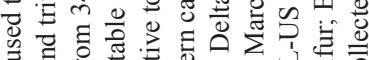

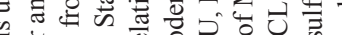
o

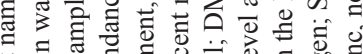

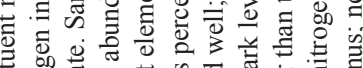

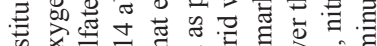

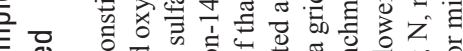

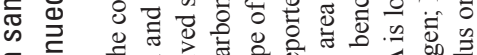

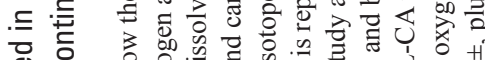

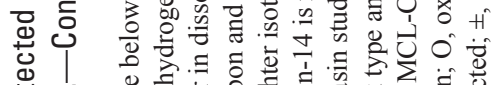

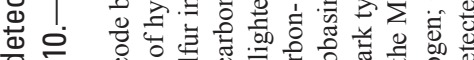

กิ

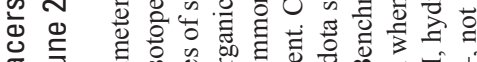

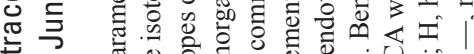

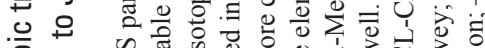

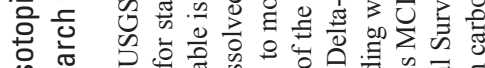

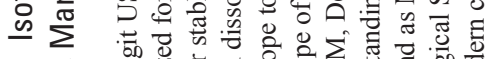

บ

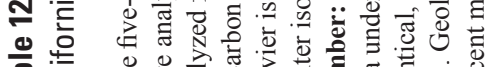

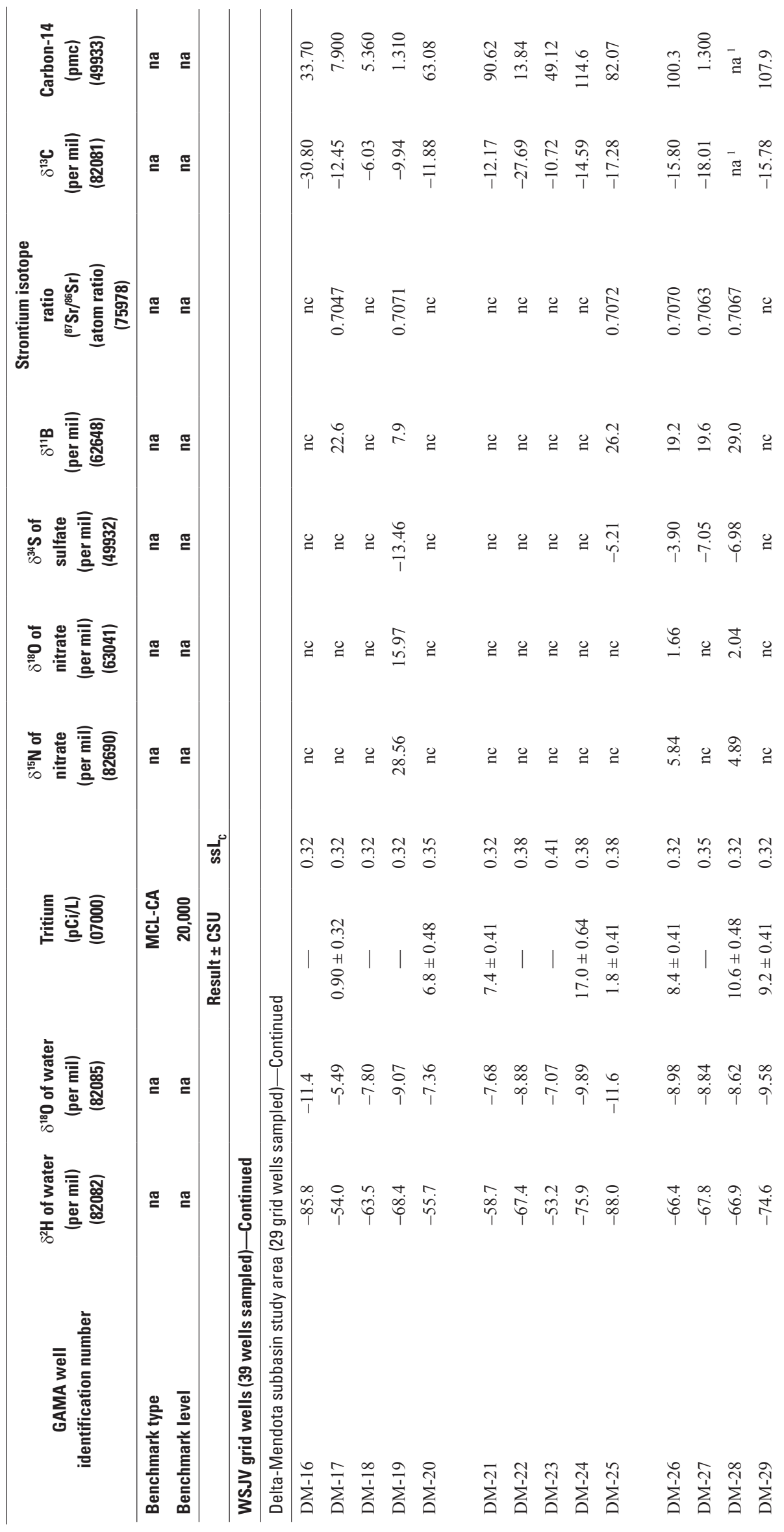




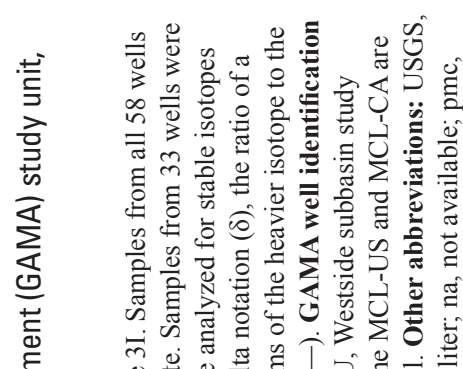

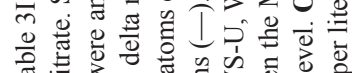

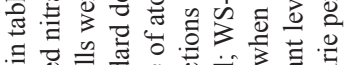

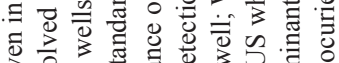

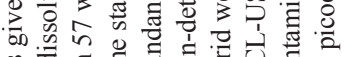

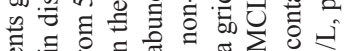

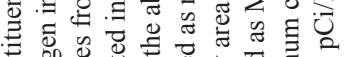

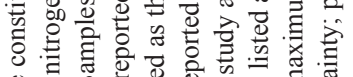
ठ चूँ

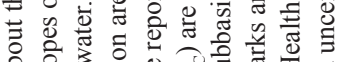

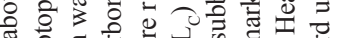
.

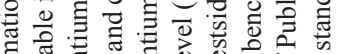

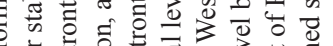

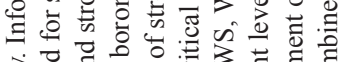

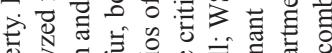

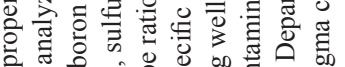
ప艹

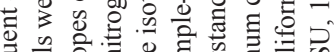

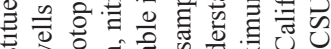

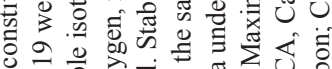

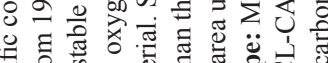

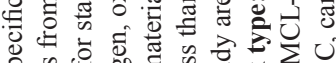
की

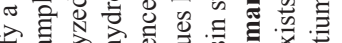

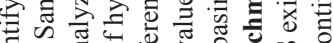

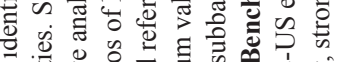

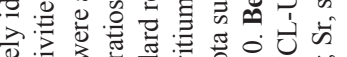

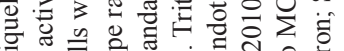

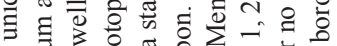

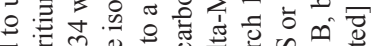

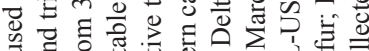

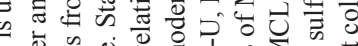
o

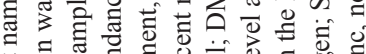

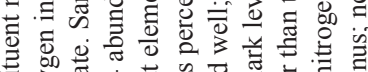

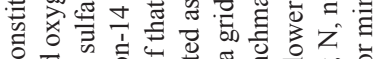

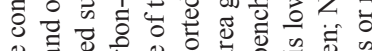

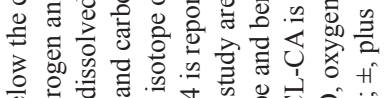
区

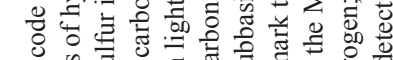

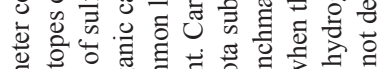

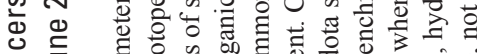

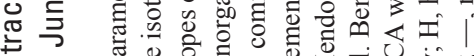

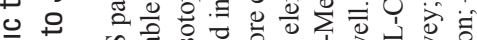

흠든

象

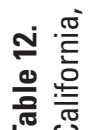
?

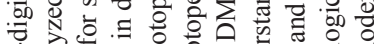
i

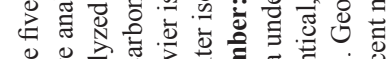

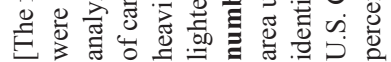

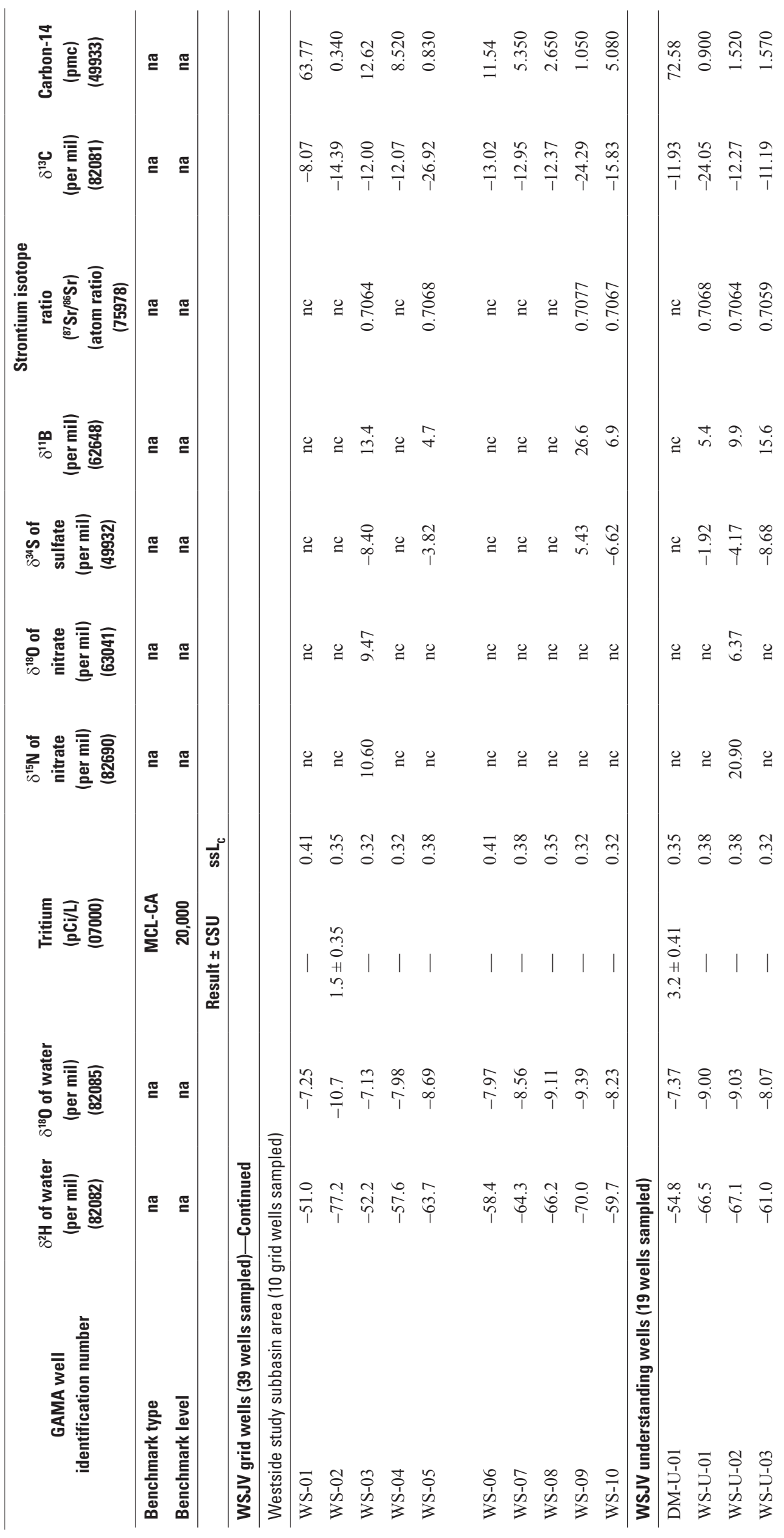




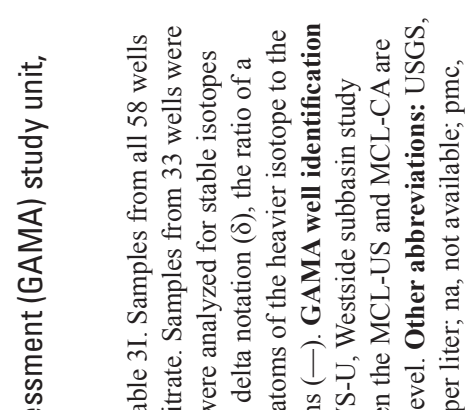

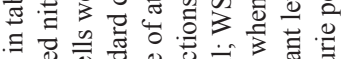

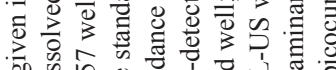

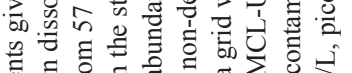

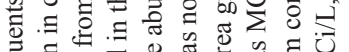

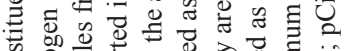

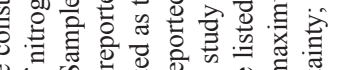

空

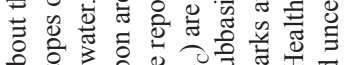

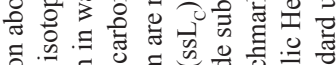

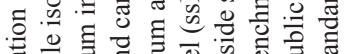

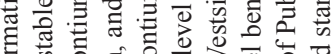

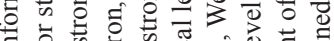

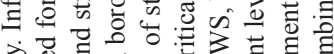

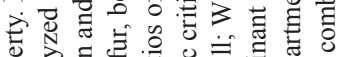

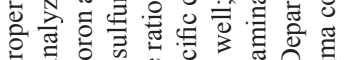

范

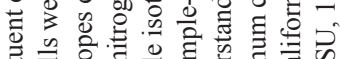

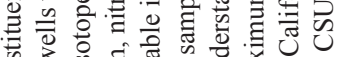

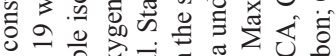

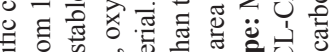

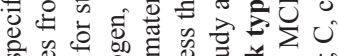

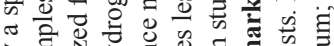

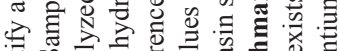

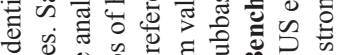

.

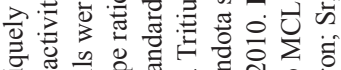

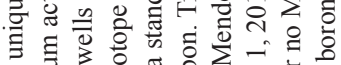

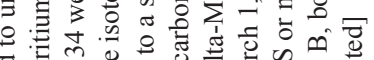

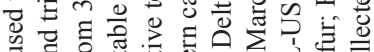

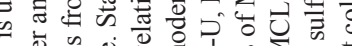

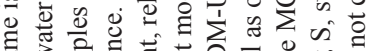

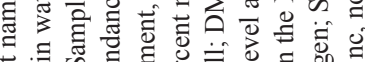

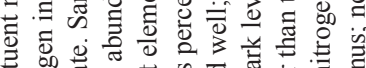

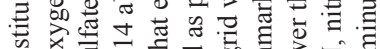

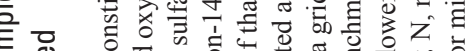

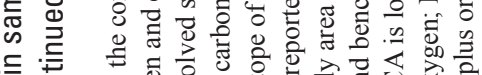

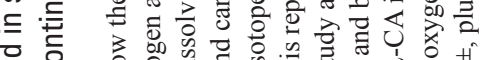

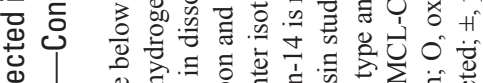

峁

ผ 丶

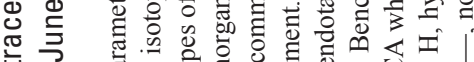

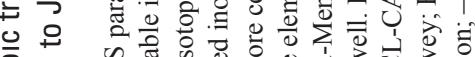

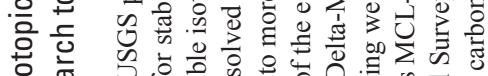

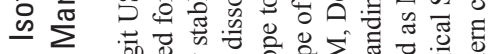

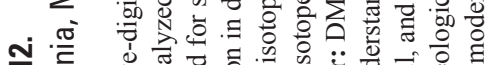

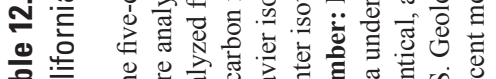

离

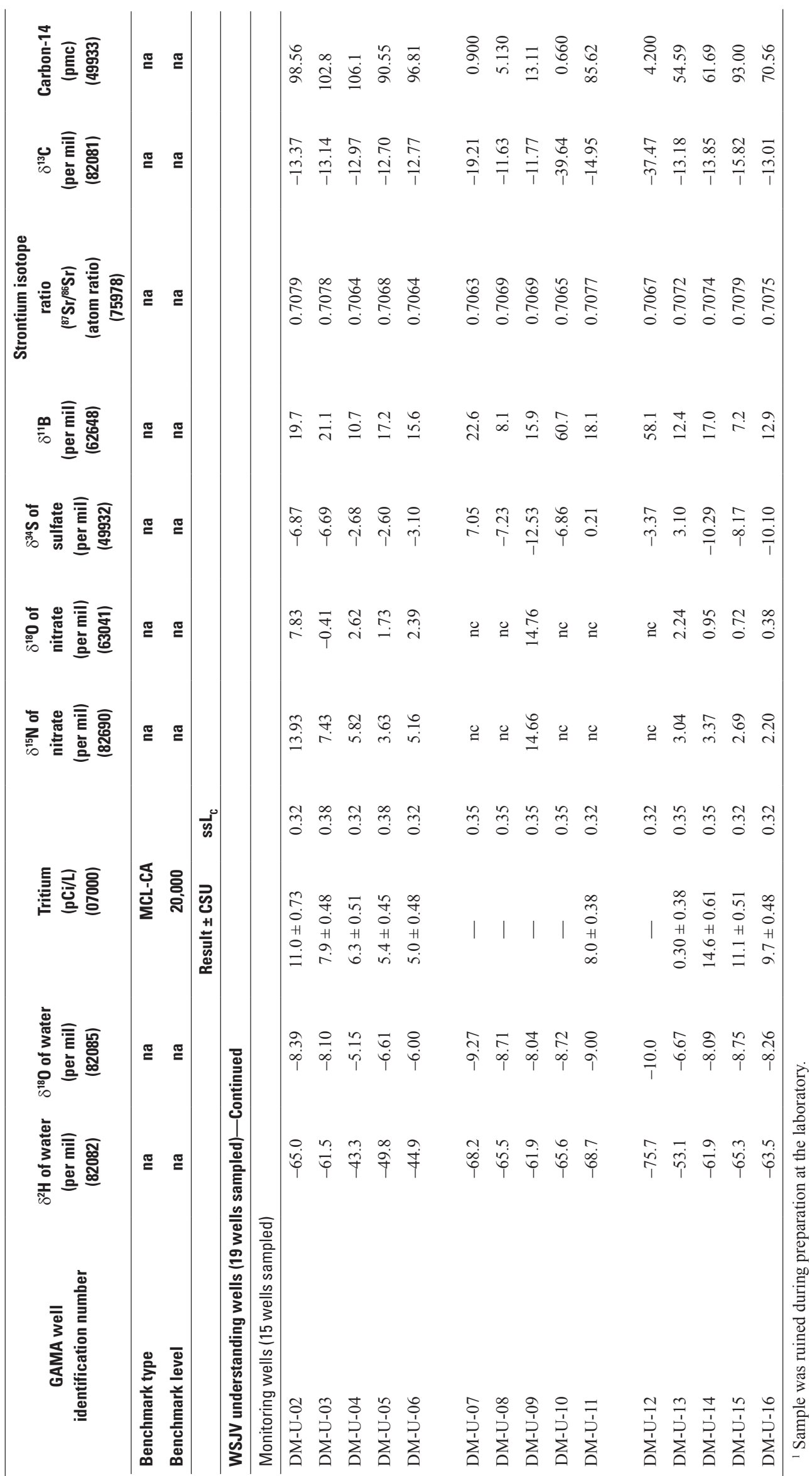


Table 13. Results for analyses of dissolved standard gases detected in samples collected for the Western San Joaquin Valley (WSJV) Groundwater Ambient Monitoring and Assessment (GAMA) study unit, California, March to July 2010.

[The five-digit USGS parameter code below the constituent name is used to uniquely identify a specific constituent or property. Information about the constituents given in table 3I. Samples from 33 wells were analyzed for dissolved standard gases in water. GAMA well identification number: DM, DeltaMendota study area grid well; DM-U, Delta-Mendota subbasin study area understanding well; WS, Westside subbasin study area grid well; WS-U, Westside subbasin study area understanding well. Other abbreviations: USGS, U.S. Geological Survey; $\mu \mathrm{g} / \mathrm{L}$, micrograms per liter; $\mathrm{mg} / \mathrm{L}$, milligrams per liter; na, not available; - , not detected]

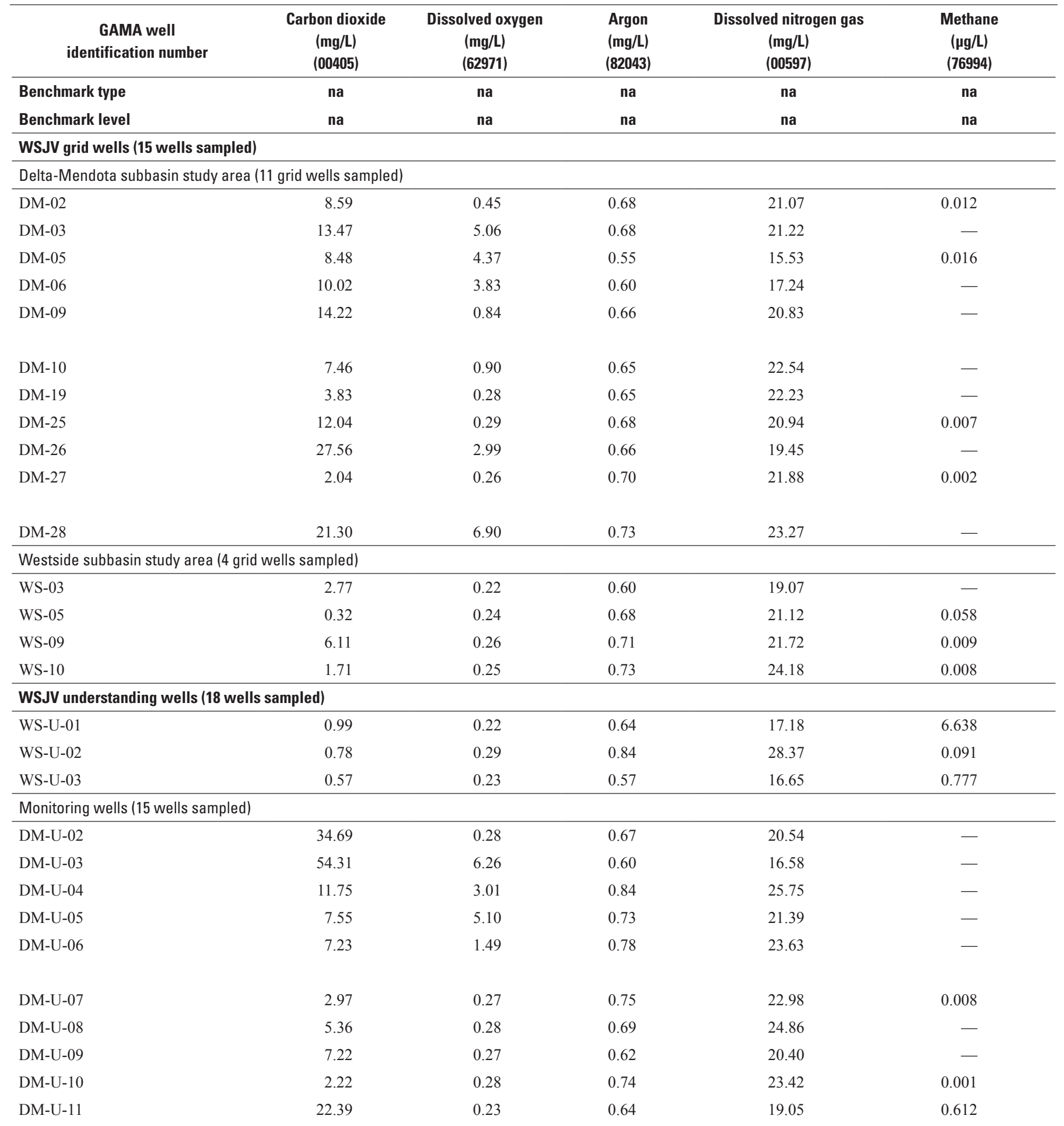


Table 13. Results for analyses of dissolved standard gases detected in samples collected for the Western San Joaquin Valley (WSJV) Groundwater Ambient Monitoring and Assessment (GAMA) study unit, California, March to July 2010. - Continued

[The five-digit USGS parameter code below the constituent name is used to uniquely identify a specific constituent or property. Information about the constituents given in table 3I. Samples from 33 wells were analyzed for dissolved standard gases in water. GAMA well identification number: DM, DeltaMendota study area grid well; DM-U, Delta-Mendota subbasin study area understanding well; WS, Westside subbasin study area grid well; WS-U, Westside subbasin study area understanding well. Other abbreviations: USGS, U.S. Geological Survey; $\mu \mathrm{g} / \mathrm{L}$, micrograms per liter; mg/L, milligrams per liter; na, not available; - , not detected]

\begin{tabular}{|c|c|c|c|c|c|}
\hline $\begin{array}{c}\text { GAMA well } \\
\text { identification number }\end{array}$ & $\begin{array}{c}\text { Carbon dioxide } \\
\text { (mg/L) } \\
(00405)\end{array}$ & $\begin{array}{c}\text { Dissolved oxygen } \\
\text { (mg/L) } \\
(62971)\end{array}$ & $\begin{array}{l}\text { Argon } \\
(\mathrm{mg} / \mathrm{L}) \\
(82043)\end{array}$ & $\begin{array}{c}\text { Dissolved nitrogen gas } \\
\text { (mg/L) } \\
(00597)\end{array}$ & $\begin{array}{c}\text { Methane } \\
\text { ( } \mu \mathrm{gg} / \mathrm{L}) \\
(76994)\end{array}$ \\
\hline Benchmark type & na & na & na & na & na \\
\hline Benchmark level & na & na & na & na & na \\
\hline \multicolumn{6}{|c|}{ WSJV understanding wells (18 wells sampled)—Continued } \\
\hline \multicolumn{6}{|c|}{ Monitoring wells (15 wells sampled)—Continued } \\
\hline DM-U-13 & 15.51 & 4.79 & 0.59 & 17.22 & - \\
\hline DM-U-14 & 9.08 & 1.35 & 0.74 & 23.95 & - \\
\hline DM-U-15 & 14.80 & 1.63 & 0.68 & 19.28 & - \\
\hline DM-U-16 & 12.33 & 5.02 & 0.77 & 25.25 & - \\
\hline
\end{tabular}




\section{Appendix}

This appendix includes discussions of the methods used to collect and analyze groundwater samples and report the resulting water-quality data. These methods were selected to obtain representative samples of the groundwater from each well and to minimize the potential for contamination of the samples or bias in the data. Procedures used to collect and assess QC data, and the results of the QC assessments also are discussed.

In the WSJV study unit, groundwater samples were collected and QA/QC procedures were implemented using standard and modified USGS protocols from the NFM (U.S. Geological Survey, variously dated; Wilde and others, 1999, 2004) and the NAWQA Program (Koterba and others, 1995). The QA plan followed by the NWQL, the primary laboratory used to analyze samples for this study, is described in Maloney (2005) and Pirkey and Glodt (1998).

\section{Sample Collection and Analysis}

Prior to sampling, each well was pumped continuously to purge at least three casing-volumes of water from the well (Wilde and others, 1999). Production wells were sampled by using Teflon ${ }^{\circledR}$ tubing with brass and stainless-steel fittings attached to a sampling point on the well discharge pipe as close to the well head as possible. The sampling point was located upstream from water-storage tanks or well-head treatment systems (if present). If a chlorinating system was attached to the well, the chlorinator was shut off, when possible, before the well was purged and sampled, in order to clear all chlorine out of the system. The absence of free chlorine was verified using a $\mathrm{Hach}^{\circledR}$ field test kit. Monitoring wells were sampled by using a Grunfos ${ }^{\circledR}$ submersible sampling pump with Teflon ${ }^{\circledR}$ tubing and stainless-steel fittings. For the intermediate schedule, samples were collected at the well head using a foot-long length of Teflon ${ }^{\circledR}$ tubing. For the slow schedule, the samples were either collected in the same manner as the intermediate schedule or collected inside an enclosed chamber located inside a mobile laboratory and connected to the well head by a 10-50 ft length of the Teflon ${ }^{\circledR}$ tubing (Lane and others, 2003). All fittings and lengths of Teflon ${ }^{\circledR}$ tubing were cleaned between samples (Wilde, 2004).

For the field measurements, groundwater was pumped through a flow-through chamber (attached to the sampling point) fitted with a multi-probe meter that simultaneously measures the field water-quality indicators - dissolved oxygen, temperature, $\mathrm{pH}$, and specific conductance. Turbidity was measured in the field with a calibrated turbidity meter. Field measurements were made in accordance with protocols in the NFM (Radtke and others, 2005; Wilde and Radtke, 2005; Lewis, 2006; Wilde, 2006; Wilde and others, 2006). All sensors on the multi-probe meter were calibrated daily. Measured turbidity, dissolved oxygen, temperature, $\mathrm{pH}$, and specific conductance values were recorded at 5 -minute (min) intervals, and when these values remained stable for a minimum of $30 \mathrm{~min}$, samples for laboratory analyses then were collected.

Field measurements and instrument calibrations were recorded on field record sheets and electronically on field laptop computers using the Personal Computer Field Form (PCFF) program. Analytical service requests for the NWQL were generated by PCFF, whereas analytical service requests for non-NWQL analysis were entered into laboratory-specific spreadsheets. Information from PCFF was uploaded directly into the USGS NWIS database at the end of every week of sample collection.

Prior to sample collection, polyethylene sample bottles were pre-rinsed three times using deionized water, and then once with native sample water before sample collection. Samples requiring acidification were acidified to a $\mathrm{pH}$ of between 2 and 1 with the appropriate acids using ampoules of certified, traceable concentrated acids obtained from the NWQL.

VOC and low-level fumigant samples were each collected in three $40-\mathrm{mL}$ sample vials that were purged with three vial volumes of groundwater before bottom-filling to eliminate atmospheric contamination. One to one (1:1) hydrochloric acid to water $\left(\mathrm{HCl} / \mathrm{H}_{2} \mathrm{O}\right)$ solution was added as a preservative to the VOC samples, but not to the lowlevel fumigant samples. 1,2,3-TCP samples were collected by top-filling two $40-\mathrm{mL}$ sample vials (provided by Weck Laboratories, Inc. [Weck], City of Industry, California) that were pre-treated with $0.5 \mathrm{~mL} 6 \operatorname{Normal}(\mathrm{N}) \mathrm{HCl}$ acid as a preservative. Each sample to be analyzed for perchlorate was collected in a 125-milliliter $(\mathrm{mL})$ polystyrene bottle and then filtered in two or three $20-\mathrm{mL}$ aliquots of groundwater through a 0.20 -micrometer $(\mu \mathrm{m})$ pore-size Corning ${ }^{\circledR}$ syringetip disk filter into a sterilized $125-\mathrm{mL}$ bottle. Tritium samples were collected by bottom-filling one 1-L polyethylene bottle and one 1-L glass bottle with unfiltered groundwater, after first overfilling the bottles with three volumes of unfiltered groundwater. Total arsenic and iron (unfiltered) samples were collected by top filling a $250-\mathrm{mL}$ polyethylene bottle that was covered with tape to prevent light exposure with unfiltered groundwater and acidified with $6-\mathrm{N} \mathrm{HCl}$ as a preservative. Samples for analysis of stable isotopes of hydrogen and oxygen in water were collected in a $60-\mathrm{mL}$ clear glass bottle filled with unfiltered groundwater, sealed with a conical cap, and secured with electrical tape to prevent leakage and evaporation.

Pesticides and pesticide degradates and NDMA samples were collected in 1-L baked amber glass bottles. Samples for pesticides and pesticide degradates were filtered through a $0.7-\mu \mathrm{m}$ nominal pore-size glass fiber filter during collection, whereas the NDMA samples were filtered at Weck prior to analysis. NDMA sample containers, treated with 0.05 gram (g) of sodium thiosulfate $\left(\mathrm{Na}_{2} \mathrm{~S}_{2} \mathrm{O}_{3}\right)$ as a preservative, were provided by Weck. 
Trace element, major and minor ion, silica, and TDS samples required filling one $250-\mathrm{mL}$ polyethylene bottle with unfiltered groundwater and one $500-\mathrm{mL}$ and one $250-\mathrm{mL}$ polyethylene bottle with filtered groundwater (Wilde and others, 2004). Filtration was done using a $0.45-\mu \mathrm{m}$ pore-size PALL ${ }^{\circledR}$ unvented capsule filter that was pre-rinsed with $2 \mathrm{~L}$ of deionized water, and then rinsed with $1 \mathrm{~L}$ of groundwater prior to sampling. The $250-\mathrm{mL}$ filtered sample then was preserved with 7.5-N nitric acid. Samples for nutrients and stable isotopes of nitrogen and oxygen in dissolved nitrate each were filtered into $125-\mathrm{mL}$ brown polyethylene bottles. Samples for arsenic and iron species were filtered into a 250-mL polyethylene bottle that was covered with tape to prevent light exposure and preserved with 6-N hydrochloric acid. Samples for stable isotopes of sulfur in dissolved sulfate were filtered into 1-L polyethylene bottles. Samples for stable isotopes of boron and isotopic ratios of strontium in water were filtered into one $250-\mathrm{mL}$ polyethylene bottle and secured with electrical tape to prevent leakage and evaporation. Samples for stable isotopes of carbon in dissolved inorganic carbon and carbon-14 abundance were filtered and bottom filled into $500-\mathrm{mL}$ glass bottles that first were overfilled with three bottle volumes of filtered groundwater. These samples had no headspace and were sealed with conical caps to avoid atmospheric contamination. Samples for field alkalinity titrations were collected by filtering groundwater into a 500-mL polyethylene bottle.

Chromium species samples were collected at the hose bib at the well head using a $10-\mathrm{mL}$ syringe with an attached $0.45-\mu \mathrm{m}$ pore-size MILLEX ${ }^{\circledR} \mathrm{HA}$ disk filter. After the syringe was rinsed thoroughly and filled with groundwater, $4 \mathrm{~mL}$ of sample water was forced through the disk filter; the next $2 \mathrm{~mL}$ of the groundwater were filtered slowly into a small centrifuge vial for analysis of total chromium. Chromium-VI then was collected by attaching a small cation-exchange column to the syringe filter after conditioning the column with $2 \mathrm{~mL}$ of sample water; an additional $2 \mathrm{~mL}$ of sample water was collected in a second centrifuge vial. Both vials were preserved with 10 microliters $(\mu \mathrm{L})$ of 7.5-N nitric acid (Ball and McCleskey, 2003a, b).

DOC samples were collected from the hose bib at the well head using a Teflon ${ }^{\circledR}$ filtration apparatus attached to a foot-long length of Teflon ${ }^{\circledR}$ tubing. For each sample, $100 \mathrm{~mL}$ of groundwater and (or) certified inorganic-free blank water was first filtered to waste through the baked $0.7-\mu \mathrm{m}$ nominal pore-size glass-fiber filter, then $100 \mathrm{~mL}$ of groundwater was filtered into a $125-\mathrm{mL}$ baked amber glass bottle (Wilde and others, 2004). Each sample then was preserved immediately by lowering the $\mathrm{pH}$ to between 2 and 1 with $4.5-\mathrm{N}$ sulfuric acid.

Dissolved standard gases were collected by using a copper tube sampling apparatus attached to the hose bib at the well head. Each sample was collected by bottom filling two 150-mL glass serum bottles that were first overfilled with approximately 5 gallons of unfiltered groundwater. These samples had no headspace or air bubbles inside the bottles and were sealed underwater to avoid atmospheric contamination.

Dissolved noble gases were collected in $3 / 8$-inch-diameter copper tubes using reinforced nylon tubing connected to the hose bib at the well head. Groundwater was flushed through the tubing to dislodge bubbles before the flow was restricted with a back-pressure valve. Clamps on either side of the copper tube then were tightened, trapping a sample of groundwater for analyses of dissolved noble gases (Weiss, 1968).

Field alkalinity was measured in the mobile laboratory at the well site. Alkalinity was measured on filtered samples by Gran's titration method (Gran, 1952). Titration data were entered directly into PCFF, and the concentrations of bicarbonate $\left(\mathrm{HCO}_{3}^{-}\right)$and carbonate $\left(\mathrm{CO}_{3}^{2-}\right)$ automatically were calculated from the titration data using the advanced speciation method (http://or.water.usgs.gov/alk/methods.html) with $\mathrm{pK}_{1}=6.35, \mathrm{pK}_{2}=10.33$, and $\mathrm{pK}_{\mathrm{W}}=14$. Concentrations of $\mathrm{HCO}_{3}{ }^{-}$and $\mathrm{CO}_{3}{ }^{2-}$ also were calculated from the laboratory alkalinity and laboratory $\mathrm{pH}$ measurements.

Temperature-sensitive samples were stored on ice prior to, and during daily shipping to the various laboratories. The non-temperature- or non-time-sensitive samples for chromium species, tritium, stable isotopes of hydrogen and oxygen in water, stable isotopes of sulfur in dissolved sulfate, stable isotopes of boron, isotopic ratios of strontium in water, and dissolved noble gases were shipped monthly. Temperatureor time-sensitive samples for VOCs, low-level fumigants, pesticides and pesticide degradates, perchlorate, NDMA, 1,2,3-TCP, trace elements, nutrients, DOC, major and minor ions, silica, and TDS were shipped daily. The temperaturesensitive samples for total (unfiltered) arsenic and iron, filtered arsenic and iron species, and dissolved standard gases were stored on ice and shipped weekly. Samples for stable isotopes of nitrogen and oxygen in dissolved nitrate and stable isotopes of carbon in dissolved inorganic carbon and carbon-14 abundance were stored on ice, archived in a laboratory refrigerator and (or) freezer, and shipped after results for nitrate and alkalinity were received from the NWQL.

Nine laboratories performed chemical analyses for this study (table A1), although most of the analyses were performed at the NWQL or by laboratories contracted by the NWQL. The NWQL maintains a rigorous QA program (Pirkey and Glodt, 1998; Maloney, 2005). Laboratory QC samples, including method blanks, continuing calibration verification standards, standard reference samples, reagent spikes, external certified reference materials, and external blind proficiency samples are analyzed regularly. Method detection limits are tested continuously, and laboratory reporting levels are updated accordingly. NWQL maintains National Environmental Laboratory Accreditation Program (NELAP) and other certifications (http://www.nelac-institute.org/accredlabs.php). In addition, the USGS Branch of Quality Systems (BQS) maintains independent oversight of QA at the NWQL and laboratories contracted by the NWQL. The BQS also 
runs the National Field Quality Assurance Program (NFQA) that includes annual testing of all USGS field personnel for proficiency in making field water-quality measurements (http://internalbqs.cr.usgs.gov/NFQA/NFQA.php). Results for analyses made at the NWQL or by laboratories contracted by the NWQL are uploaded directly into the USGS NWIS database. Results of analyses made at other laboratories are compiled in a project database and uploaded from there into the USGS NWIS database. Some laboratory QC data are stored in the USGS NWIS database also.

\section{Data Reporting}

\section{Laboratory Reporting Conventions}

The USGS NWQL uses different conventions for reporting results for organic, inorganic, and radioactive constituents. The USGS NWQL uses the LRL for reporting analytical results for most organic constituents. The LRL is set to minimize the reporting of false negatives (not detecting a compound when it actually is present in a sample) to less than 1 percent (Childress and others, 1999). The NWQL updates LRL values regularly, and the values listed in this report were in effect during the period that groundwater samples from the WSJV study unit were analyzed (March to July 2010).

The LRL usually is set at two times the long-term method detection level (LT-MDL). The LT-MDL is derived from the standard deviation of at least 24 method detection level (MDL) determinations made over an extended period of time. The MDL is the minimum concentration of a substance that can be measured and reported with 99-percent confidence that the concentration is greater than zero (at the MDL there is less than 1 percent chance of a false positive). LT-MDLs continually are monitored and updated (Childress and others, 1999; U.S. Environmental Protection Agency, 2002). Concentrations less than the LT-MDL are reported as nondetections with a dash (-) in the data tables.

Concentrations between the LRL and the LT-MDL are reported as having a higher degree of uncertainty (coded by the letter "E" preceding the values in the tables and text). For information-rich methods, detections less than the LT-MDL have high certainty of presence, but the precise concentration is uncertain. These values are also E-coded. Informationrich methods are those that utilize gas chromatography or high-performance liquid chromatography (HPLC) with mass spectrometry detection, such as those methods used to analyze VOCs and pesticides. Compounds are identified by presence of characteristic fragmentation patterns in their mass spectra in addition to being quantified by measurement of peak areas at their associated chromatographic retention times. E-coded values also may result from detections outside the range of calibration standards, from detections that did not meet all laboratory QC criteria, and from samples that were diluted prior to analysis (Childress and others, 1999).
Some constituents in this study are reported by using minimum reporting levels (MRLs) or method uncertainties (MU). The MRL is the smallest measurable concentration of a constituent that may be reliably reported when using a given analytical method (Timme, 1995). The MU generally indicates the precision of a particular analytical measurement; it gives a range of values wherein the true value will be found.

Results for most constituents are given using the LRL, MDL, or MRL values provided by the analyzing laboratories. Results for some organic and inorganic constituents are presented using SRLs derived from assessing results from QC samples associated with groundwater samples collected as part of the GAMA-PBP [see the appendix section titled "Methods for Determining Study Reporting Levels (SRLs)"].

The methods used for analysis of tritium measure activities by counting techniques (table A1). Activity often is used instead of concentration for reporting the presence of radioactive constituents. Activity of these constituents in groundwater is measured in units of picocuries per liter $(\mathrm{pCi} / \mathrm{L})$, and $1 \mathrm{pCi} / \mathrm{L}$ is approximately equal to two atoms decaying per minute. The number of atoms decaying is equal to the number of alpha or beta particles emitted.

The reporting limit for tritium is based on sample-specific critical levels ( $\mathrm{ssL}_{\mathrm{C}}$ ) (McCurdy and others, 2008). The critical level is analogous to the LT-MDL used for reporting analytical results for organic and non-radioactive inorganic constituents. Here, the critical level is defined as the minimum measured activity that indicates a positive detection of the radionuclide in the sample with less than a 5-percent probability of a false positive detection. Sample-specific critical levels are used for radioactive measurements because the critical level is sensitive to sample size and sample yield during analytical processing and is dependent on instrument background, on counting times for the sample and background, and on the characteristics of the instrument being used and the nuclide being measured. An $\mathrm{ssL}_{\mathrm{C}}$ is calculated for each sample, and the measured activity in the sample is compared to the $\mathrm{ssL}_{\mathrm{C}}$ associated with that sample. Measured activities less than the $\mathrm{ssL}_{\mathrm{C}}$ are reported as non-detections with a dash (-) in the data tables.

The analytical uncertainties associated with measurement of activities also are sensitive to sample-specific parameters, including sample size, sample yield during analytical processing, and time elapsed between sample collection and various steps in the analytical procedure, as well as parameters associated with the instrumentation. Therefore, measured activities of tritium are reported with sample-specific combined standard uncertainties (CSU). The CSU is reported at the 68-percent confidence level (1-sigma).

Stable isotopic compositions of hydrogen, oxygen, nitrogen, sulfur, boron, and carbon are reported as relative isotope ratios in units of per mil using the standard delta notation (Coplen and others, 2002): 


$$
\delta^{i} E=\left[\frac{R_{\text {sample }}}{R_{\text {reference }}}-1\right] x 1,000 \text { per mil }
$$

where

$$
\begin{aligned}
& i \quad \begin{array}{l}
\text { is the atomic mass of the heavier isotope of } \\
\text { the element, }
\end{array} \\
& E \quad \text { is the element ( } \mathrm{H} \text { for hydrogen, O for oxygen, } \\
& \text { N for nitrogen, } \mathrm{S} \text { for sulfur, B for boron, } \\
& \text { and } \mathrm{C} \text { for carbon), } \\
& R_{\text {sample }} \quad \begin{array}{l}
\text { is the ratio of the abundance of the heavier } \\
\text { isotope of the element }\left({ }^{2} \mathrm{H},{ }^{18} \mathrm{O},{ }^{15} \mathrm{~N},\right.
\end{array} \\
& \left.\quad{ }^{34} \mathrm{~S},{ }^{11} \mathrm{~B},{ }^{13} \mathrm{C}\right) \text { to the lighter isotope of the } \\
& \text { element }\left({ }^{1} \mathrm{H},{ }^{16} \mathrm{O},{ }^{14} \mathrm{~N},{ }^{32} \mathrm{~S},{ }^{10} \mathrm{~B},{ }^{12} \mathrm{C}\right) \text { in the } \\
& \text { sample, and } \\
& \quad \text { is the ratio of the abundance of the heavier } \\
& \text { isotope of the element to the lighter isotope } \\
& \text { of the element in the reference material. }
\end{aligned}
$$

The reference material for oxygen and hydrogen is Vienna Standard Mean Ocean Water (VSMOW), which is assigned $\delta^{18} \mathrm{O}$ and $\delta^{2} \mathrm{H}$ values of 0 per mil (note than $\delta^{2} \mathrm{H}$ is sometimes written as $\delta \mathrm{D}$ because the common name of the heavier isotope of hydrogen, hydrogen-2, is deuterium). The reference material for nitrogen is atmospheric nitrogen gas, which is assigned a $\delta^{15} \mathrm{~N}$ value of 0 per mil. The reference material for sulfur is Vienna Canon Diablo Troilite (VCDT), which is assigned a $\delta^{34} \mathrm{~S}$ value of 0 per mil. The reference material for boron is the National Institute of Standards and Technology (NIST) reference material SRM 951 boric acid, which is assigned a $\delta^{11} \mathrm{~B}$ value of 0 per mil (Coplen and others, 2002). The reference material for carbon is Vienna Pee Dee Belemnite (VPDB), which is assigned a $\delta^{13} \mathrm{C}$ value of 0 per mil. Positive values indicate enrichment of the heavier isotope, and negative values indicate depletion of the heavier isotope, compared to the ratios observed in the standard reference material. Isotopic ratios of strontium in water are presented as the abundance of atoms of the heavier isotope $\left({ }^{87} \mathrm{Sr}\right)$ to the lighter isotope $\left({ }^{86} \mathrm{Sr}\right)$ of the element.

\section{Constituents Determined by Multiple Methods or Laboratories}

Ten constituents targeted in this study were measured by more than one analytical method or by more than one laboratory (table A2). The preferred methods for these constituents were selected on the basis of the procedure recommended by the NWQL (http://wwwnwql.cr.usgs.gov/ dyn.shtml?Preferred method_selection_procedure).

The water-quality indicators - alkalinity, $\mathrm{pH}$, and specific conductance - were measured in the field and at the NWQL. The field measurements are the preferred method for all three constituents; however, both measurements are reported (table 4). Field values are generally preferred because field conditions are considered more representative of groundwater conditions (Hem, 1985).

DBCP and EDB each appear on the following NWQL analytical schedules: VOCs (Schedule 2020; table 3A) and low-level fumigants (Schedule 1306; table 3B). For constituents collected on Schedules 2020 and 1306, the preferred method was Schedule 1306.

1,2,3-TCP was measured at the NWQL (reporting level was an LRL of $0.12 \mu \mathrm{g} / \mathrm{L}$ ) and Weck (reporting level was an MRL of $0.005 \mu \mathrm{g} / \mathrm{L}$ ) (table 3A, D). Both sets of results are reported for this constituent.

For total arsenic, chromium, and iron (filtered) concentrations, the approved method, Schedule 1948 (table 3E), used by the NWQL is preferred over the research methods used by the NRP-TML (table 3H); however, both measurements are reported (tables 8 and 11). The concentrations measured by the NRP-TML are only used to calculate ratios of redox species for arsenic, chromium, and iron.

For example,

$$
\frac{\mathrm{Cr}(\mathrm{III})}{\mathrm{Cr}(\mathrm{VI})}=\frac{\mathrm{Cr}(\mathrm{T})-\mathrm{Cr}(\mathrm{VI})}{\mathrm{Cr}(\mathrm{VI})}
$$

where

$\mathrm{Cr}(\mathrm{T}) \quad$ is the total chromium concentration (measured),

$\mathrm{Cr}(\mathrm{VI}) \quad$ is the concentration of hexavalent chromium (measured), and

$\mathrm{Cr}$ (III) is the concentration of trivalent chromium (calculated).

Tritium also was measured at two laboratories: LLNL and USGS Stable Isotope and Tritium Laboratory, Menlo Park, California (SITL) (table 3I). Only tritium data from the SITL was available for reporting at the time of this publication (table 12).

\section{Quality-Assurance Methods and Results}

The purpose of QA is to identify which data best represent environmental conditions and which may have been affected by contamination or bias during sample collection, processing, storage, transportation, and (or) laboratory analysis. Four types of QC measurements were evaluated in this study: (1) blank samples were collected to assess positive bias as a result of contamination during sample handling or analysis, (2) replicate samples were collected to assess variability, (3) matrix-spike tests were done to assess positive or negative bias, and (4) surrogate compounds were added to samples analyzed for organic constituents to assess potential bias from laboratory analytical methods. Results that were 
found to have significant bias, on the basis of the QC data collected from this study and previous studies, were flagged with an appropriate remark code (described in subsequent sections) and were not used to calculate detection frequencies or other statistical analyses.

\section{Blanks}

The primary purposes of collecting blanks are to evaluate the magnitude of potential contamination of samples with compounds of interest during sample handling or analysis, and to identify and mitigate the sources of sample contamination.

\section{Methods of Blank Collection and Analysis}

Blanks were collected using blank water certified by the NWQL to contain less than the reporting levels for selected constituents investigated in the study (http://wwwnwql.cr.usgs. gov/USGS/OBW/obw.html). Nitrogen-purged, organic-free blank water was used for blanks of organic constituents, and inorganic-free blank water was used for blanks of inorganic constituents. Three types of blanks were collected:

- Field blanks were collected to assess potential contamination of samples during collection, processing, transport, and analysis. To collect field blanks, blank water either was pumped or poured through the sampling equipment (fittings and tubing) used to collect groundwater samples, then processed and transported using the same protocols used for the groundwater samples. Typically, 12 liters of blank water were pumped or poured through the sampling equipment before each field blank was collected. Field blanks were analyzed for VOCs, low-level fumigants, pesticides and pesticide degradates, perchlorate, 1,2,3TCP, NDMA, trace elements, nutrients, DOC, major and minor ions, silica, TDS, total arsenic and iron (unfiltered), and arsenic, chromium, and iron species (filtered).

- Source-solution blanks are collected at the beginning of a study or when using a new lot of blank water to assess potential contamination of samples during transport and analysis, and potential contamination of the certified blank water obtained from the NWQL. Source-solution blanks were collected by pouring blank water directly into sample containers that were preserved, stored, shipped, and analyzed in the same manner as the groundwater samples. Source-solution blanks were analyzed for VOCs, low-level fumigants, pesticides and pesticide degradates, perchlorate, NDMA, 1,2,3-TCP, trace elements, major and minor ions, silica, TDS, total arsenic and iron (unfiltered), and arsenic, chromium, and iron species (filtered).

- An equipment blank was collected at the beginning of the study unit at the USGS Sacramento Field Office to assess whether the Grunfos ${ }^{\circledR}$ submersible sampling pump was sufficiently clean to be used for collection of samples from monitoring wells in the WSJV study unit. The equipment blank was analyzed for VOCs, pesticides and pesticide degradates, perchlorate, NDMA, 1,2,3-TCP, trace elements, nutrients, DOC, major and minor ions, silica, and TDS.

Blanks were not collected for stable isotopes. Stable isotopes of hydrogen, oxygen, nitrogen, sulfur, boron, strontium, and carbon are an intrinsic property of any of these elements; therefore, the concept of a blank does not apply to these ratios. In addition, blanks were not collected for tritium or dissolved gases. Tritium and dissolved gases are in the atmosphere and would dissolve into any solution used in collecting a blank, making it impractical to collect a blank for these constituents.

\section{Methods for Determining Study Reporting Levels (SRLs)}

SRLs for selected VOCs were defined by Fram and others (2012) on the basis of the assessment of results from field blanks, source-solution blanks, laboratory instrument blanks, and groundwater samples from the first 32 GAMA PBP study units (May 2004 through September 2010). SRLs were established for those VOCs that had evidence of potential contamination due to field or laboratory processes. Detections of VOCs having concentrations less than or equal to the SRLs were reclassified as non-detections.

SRLs for trace elements detected in field blanks collected in the first 20 GAMA PBP study units (May 2004 through January 2008) were defined by Olsen and others (2010) on the basis of statistical assessment of results from the field blanks. The assessment used order statistics and binomial probabilities to construct an upper confidence limit (Hahn and Meeker, 1991) for the maximum concentration of constituents possibly introduced while groundwater samples were collected, transported, and analyzed. Detections of trace elements having concentrations less than or equal to the SRLs were reported with $\mathrm{a} \leq$ symbol preceding the value to indicate that the true value may be less than or equal to the reported value (including the possibility of being a non-detection).

SRLs for other constituents collected for the WSJV study unit were defined as equal to the highest concentration measured in the blanks. Detections of organic constituents in groundwater samples at concentrations less than or equal to the SRLs have been reclassified as non-detections. Detections of inorganic constituents in groundwater samples at concentrations less than or equal to the SRLs have been reclassified with a $\leq$ symbol preceding the reported value to indicate that the true value may be less than or equal to the reported value (including the possibility of being a non-detection).

In the USGS NWIS database, data affected by SRLs (if any) are accompanied with the following comment: Result is $<$ or $=$ reported value, based on $\mathrm{QC}$ data. 


\section{Detections in Blanks and Application of SRLs}

Table A3 presents a summary of detections in the blanks (eight field blanks, three source-solution blanks, and one equipment blank) and the SRLs that were applied for the WSJV study unit. Blanks were collected at up to 17 percent of the sites sampled in the WSJV study unit.

Four VOCs (acetone, carbon disulfide, chloroform, and toluene) were detected in blanks collected for the WSJV study unit, and each also have SRLs defined by Fram and others (2012). Detections of VOCs in groundwater samples with concentrations less than or equal to the SRL (defined by the blank detections or by Fram and others, 2012) were flagged with a $\leq$ symbol and reclassified as non-detections. An additional four VOCs (1,2,4-trimethylbenzene, ethylbenzene, $m$-plus $p$-xylene, and $o$-xylene) have SRLs defined by Fram and others (2012) and were detected in groundwater samples (table 5).

Acetone was detected in one field blank at a concentration of E0.3 $\mu \mathrm{g} / \mathrm{L}$. Acetone was not detected in groundwater samples; therefore, definition of an SRL was not necessary.

Carbon disulfide was detected in one field blank at a concentration of $0.06 \mu \mathrm{g} / \mathrm{L}$. This concentration is greater than the SRL of E0.03 $\mu \mathrm{g} / \mathrm{L}$ defined by Fram and others (2012). The SRL of $0.03 \mu \mathrm{g} / \mathrm{L}$ was defined on the basis of statistical assessment of results from field blanks collected during 32 GAMA study units; therefore, it was considered appropriate to use this value, rather than the higher concentration measured in the field blank, as the SRL.

Chloroform was detected in the equipment blank at a concentration of E $0.02 \mu \mathrm{g} / \mathrm{L}$. This concentration is equal to the defined SRL for groundwater samples collected with monitoring well equipment (Fram and others, 2012).

$1,2,4$-Trimethylbenzene has an SRL of $0.56 \mu \mathrm{g} / \mathrm{L}$ as defined by Fram and others (2012). 1,2,4-Trimethylbenzene was detected at a concentration less than the SRL in one groundwater sample (WS-07: E0.02 $\mu \mathrm{g} / \mathrm{L}$ ); therefore, this result is not presented in table 5 .

Toluene was detected in three field blanks and one source-solution blank at concentrations ranging from E0.01 $\mu \mathrm{g} / \mathrm{L}$ to $0.04 \mu \mathrm{g} / \mathrm{L}$. Toluene has an SRL of $0.69 \mu \mathrm{g} / \mathrm{L}$ as defined by Fram and others (2012). The SRL of $0.69 \mu \mathrm{g} / \mathrm{L}$ was used on the basis on these results. Toluene was detected at concentrations less than or equal to the SRL in two groundwater samples (WS-U-02: $0.03 \mu \mathrm{g} / \mathrm{L}$; DM-U-11: E0.02 $\mu \mathrm{g} / \mathrm{L}$ ); the latter of which (DM-U-11) was reclassified as a non-detection.

Ethylbenzene, $m$ - plus $p$-xylene, and $o$-xylene were not detected in blanks collected for the WSJV study unit, but were detected in samples from wells WS-U-01 and WS-U-02. Additionally, toluene was detected in groundwater samples from WS-U-02 (see previous paragraph). The concentrations of ethylbenzene and $o$-xylene in WS-U-01 and of $m$-plus $p$-xylenes, $o$-xylene, and toluene in WS-U-02 were less than the SRLs established by Fram and others, 2012). However, multiple lines of evidence suggested that the detections of the hydrocarbons ethylbenzene, $m$ - plus $p$-xylene, $o$-xylene, and toluene are more likely to be the result of environmental occurrence of these compounds in the groundwater sampled from these wells; therefore, SRLs were not applied and the data were not reclassified in table 5.

First, WS-U-02 was previously sampled by the GAMAPBP in 2005 (well TLR-07, Southeast San Joaquin Valley: Burton and others, 2008); ethylbenzene, $m$ - plus $p$-xylene, $o$-xylene, and toluene and high concentrations of benzene were all detected in this well in 2005 and in the sample collected for the WSJV study unit. Such repeated detections of the same compounds in the same well sampled 5 years apart are more likely to reflect actual presence of these compounds in the well rather than random contamination. Second, data from the CDPH database indicated historical detections of benzene in WS-U-01 and WS-U-02, often at concentrations greater than the MCL-CA of $1 \mu \mathrm{g} / \mathrm{L}$. These results indicate that there is a history of hydrocarbon presence in the sampled groundwater in these wells. Because the LRLs of the analyses reported in the CDPH database are much higher than those used by the GAMA-PBP and because concentrations of ethylbenzene, $m$-plus $p$-xylene, $o$-xylene, and toluene measured by the GAMA-PBP were much lower than the concentrations of benzene, it is not surprising that these other hydrocarbons have not generally been detected in the CDPH analyses. Third, it is not unexpected that groundwater that is highly affected by hydrocarbon contamination (as evidenced by the high concentrations of benzene in these wells) would also have detections of other relatively soluble hydrocarbons, including ethylbenzene, $m$ - plus $p$-xylene, $o$-xylene, and toluene.

Seven trace elements (cobalt, copper, lead, manganese, molybdenum, silver, and tungsten) were detected in blanks collected for the WSJV study unit. An additional four trace elements (chromium, iron, nickel, and zinc) were detected in groundwater samples at concentrations less than or equal to the SRLs defined by Olsen and others (2010). Detections of trace elements in groundwater samples with concentrations less than or equal to the SRL were flagged with $a \leq$ symbol in table 8.

Cobalt was detected in all eight field blanks and in the equipment blank at concentrations ranging from $0.10 \mu \mathrm{g} / \mathrm{L}$ to $0.33 \mu \mathrm{g} / \mathrm{L}$. An SRL of $0.33 \mu \mathrm{g} / \mathrm{L}$ was defined on the basis of the blank results.

Copper was detected in two field blanks at concentrations of E0.59 $\mu \mathrm{g} / \mathrm{L}$ and E0.84 $\mu \mathrm{g} / \mathrm{L}$, respectively. Copper has an SRL of $1.7 \mu \mathrm{g} / \mathrm{L}$ as defined by Olsen and others (2010). The $\mathrm{SRL}$ of $1.7 \mu \mathrm{g} / \mathrm{L}$ was used on the basis of these results.

Lead was detected in all three field blanks at concentrations ranging from E0.02 $\mu \mathrm{g} / \mathrm{L}$ to $0.04 \mu \mathrm{g} / \mathrm{L}$. Lead has an SRL of $0.65 \mu \mathrm{g} / \mathrm{L}$ as defined by Olsen and others 
(2010). The SRL of $0.65 \mu \mathrm{g} / \mathrm{L}$ was used on the basis of these results.

Manganese was detected in all eight field blanks and the equipment blank at concentrations ranging from $0.21 \mu \mathrm{g} / \mathrm{L}$ to $0.52 \mu \mathrm{g} / \mathrm{L}$. An SRL of $0.52 \mu \mathrm{g} / \mathrm{L}$ was defined on the basis of the blank results.

Molybdenum was detected in a field blank and the equipment blank, both at concentrations of E0.02 $\mu \mathrm{g} / \mathrm{L}$. Molybdenum was not detected in groundwater samples at concentrations less than or equal to those measured in the blanks; therefore, application of an SRL was not necessary (table 8).

Silver was detected in a field blank and the equipment blank at concentrations of $0.010 \mu \mathrm{g} / \mathrm{L}$ and E0.005 $\mu \mathrm{g} / \mathrm{L}$, respectively. An SRL of $0.010 \mu \mathrm{g} / \mathrm{L}$ was defined on the basis of the blank results.

Tungsten was detected in a field blank at a concentration of $0.03 \mu \mathrm{g} / \mathrm{L}$. Tungsten has an SRL of $0.11 \mu \mathrm{g} / \mathrm{L}$ as defined by Olsen and others (2010). The SRL of $0.11 \mu \mathrm{g} / \mathrm{L}$ was used based on these results.

Two nutrients were detected in one field blank; ammonia (as nitrogen) (E0.02 $\mu \mathrm{g} / \mathrm{L})$ and nitrite (as nitrogen) $(\mathrm{E} 0.001 \mu \mathrm{g} / \mathrm{L})$. SRLs were defined for each nutrient on the basis of the blank results.

Alkalinity and TDS each were detected in one field blank at concentrations of $\mathrm{E} 4 \mathrm{mg} / \mathrm{L}$ and $34 \mathrm{mg} / \mathrm{L}$, respectively. Alkalinity and TDS were not detected in groundwater samples at concentrations less than or equal to those measured in the field blanks; therefore, application of an SRL was not necessary (tables 4 and 10 ).

\section{Replicates}

Sequential replicate samples were collected to assess the precision of the water-quality data. Estimates of data precision are needed to assess whether differences between concentrations in samples are because of differences in groundwater quality or because of variability that may result from collecting, processing, and analyzing the samples.

\section{Methods of Assessment of Replicate Samples}

Three methods for measuring variability were used to assess precision over the range of measured concentrations found in groundwater samples. The variability between results in the pairs of sequential replicate samples was represented by the standard deviation (SD) for low concentrations and by relative standard deviation (RSD) for high concentrations (Anderson, 1987; Mueller and Titus, 2005). The RSD is defined as the SD divided by the mean concentration for each replicate pair of samples expressed as a percentage. The boundary between concentrations of each metric was used was defined as five times the selected reporting level (RL) for each constituent. The RL may be an LRL, SRL, MDL, or MRL for each constituent; therefore pairs with mean concentrations
$<5 \mathrm{RL}$ used the SD, and pairs with mean concentrations $\geq 5 \mathrm{RL}$ used the RSD.

Replicate pairs of analyses of all constituents except for radiochemical constituents were evaluated as follows:

- If both values were reported as detections, the SD or RSD was calculated. Acceptable precision is defined as an SD of less than $1 / 2$ RL or an RSD of less than 10 percent. For comparison, an RSD of 10 percent is equivalent to a relative percent difference (RPD) of 14 percent.

- If both values were reported as non-detections, the variability was set to zero by definition.

- If one value was reported as a non-detection, and the other value was reported as a detection less than the $\mathrm{RL}$, then a value of zero was substituted for the nondetection, and the SD was calculated. Substituting zero for the non-detection would yield the maximum estimate of variability for the replicate pair.

- If one value for a sample pair was reported as a non-detection and the other value was flagged with a $\leq$ symbol (less than or equal to the SRL), or if both values were flagged with a $\leq$ symbol, the SD was not calculated because the values may be analytically identical. The $\leq$ symbol indicates that the value is a maximum potential concentration and the true concentration could be less than the RL for the other sample in the pair.

- If one value was reported as a non-detection and the other value was reported as a detection greater than the RL, the variability for the pair was considered unacceptable.

Replicate pairs of analyses of radiochemical constituents were evaluated using the following equation (McCurdy and others, 2008):

$$
z=\frac{\left|R_{1}-R_{2}\right|}{\sqrt{\left(C S U_{1}^{2}+C S U_{2}^{2}\right)}}
$$

where

$z \quad$ is the test statistic,

$R_{1}$ and $R_{2} \quad$ are the results for the two samples in the replicate pair, and

$\mathrm{CSU}_{1}$ and $\mathrm{CSU}_{2}$ are the combined standard uncertainties associated with the results.

Values of $z<1.65$ correspond to significant levels (p) $<\alpha$, where $\alpha=0.05$, and thus indicate replicate pairs with acceptable precision. Replicate pairs with values that are statistically indistinguishable at a confidence level $(\alpha)$ of $\alpha=0.05$ are defined as acceptable. 
If results from replicate sample pairs indicate that variability is unacceptable for a constituent, then this greater variability must be considered when interpreting the data. If measured concentrations are slightly greater than a waterquality benchmark, then actual concentrations could be less than that benchmark. Similarly, if measured concentrations are slightly less than a water-quality benchmark, then actual concentrations could be greater than a benchmark. If a constituent has high variability in replicate sample pairs, then a larger difference between concentrations measured in two samples is required to conclude that the two samples have significantly different concentrations.

\section{Variability in Replicate Samples}

Table A4A-B summarize the results of replicate analyses for constituents detected in groundwater samples collected in the WSJV study unit. Replicate samples were collected for up to 10 percent of the samples collected. Of the 1,370 replicate pairs of constituents analyzed, 93 were for constituents detected in at least one groundwater sample. Of these 93 pairs, none were outside the limits for acceptable variability.

Six replicate pairs of samples were analyzed for the VOCs, and all pairs were composed of two values reported as non-detections with the exception of one replicate pair for chloroform and one replicate pair for MTBE. The replicate pairs all yielded two values reported as detections, and all replicate pair analysis resulted in SDs within acceptable precision.

Six replicate pairs of samples were analyzed for the lowlevel fumigants, and all pairs were composed of two values reported as non-detections.

Six replicate pairs of samples were analyzed for the pesticide and pesticide degradate compounds, and all pairs were composed of two values reported as non-detections with the exception of two replicate pairs each for metolachlor and one replicate pair for simazine, deethylatrazine, atrazine, hexazinone, $S$-ethyl-dipropylthiocarbamate (EPTC), and 3,4-dichloroaniline. The replicate pairs all yielded two values reported as detections, and all replicate pair analysis resulted in SDs within acceptable precision.

Six replicate pairs for perchlorate and 1,2,3-TCP and four replicate pairs for NDMA were analyzed at Weck for variability. Five of the replicate pairs for perchlorate and 1,2,3-TCP and all of the replicate pairs for NDMA were composed of two values reported as non-detections. The remaining replicate pairs for perchlorate and 1,2,3-TCP yielded two values reported as detections, and each replicate pair analysis resulted in an SD or RSD within acceptable precision.

Six replicate pairs of samples were analyzed for DOC, and one of these pairs was composed of two values reported as non-detections. The five remaining replicate pairs yielded two values reported as detections, and all replicate pair analyses resulted in SDs within acceptable precision.
Replicate pairs of samples were analyzed for trace elements, nutrients, major and minor ions, silica, TDS, total arsenic and iron (unfiltered), and arsenic, chromium, and iron species (filtered). All replicate pairs were either composed of two values reported as non-detections or two values reported as detections. The analyses for all replicate pairs reported as detections resulted in SDs and RSDs within acceptable variability.

Six replicate pairs for tritium were analyzed for variability. All replicate pairs yielded statistically similar results $(\mathrm{p} \leq 0.05)$ and were, therefore, considered acceptable.

\section{Matrix Spikes}

Addition of a known concentration of a constituent (spike) to a replicate groundwater sample enables the laboratory to determine the effect of the matrix, in this case groundwater, on the analytical technique used to measure the constituent. The known compounds added in matrix spikes are the same as those analyzed in the groundwater samples. This enables an analysis of matrix interferences on a compoundby-compound basis. For this study, matrix spikes were added by the laboratories performing the analysis rather than in the field. Low and high matrix-spike recoveries may be a potential concern if the concentration of a compound in a groundwater sample is close to the benchmark; a low recovery could result in a falsely measured concentration less than the benchmark, whereas a high recovery could result in a falsely measured concentration greater than the benchmark.

The GAMA-PBP defined the data-quality objective range for acceptable median matrix-spike recoveries as 70 to 130 percent. Only constituents with median matrix-spike recoveries outside of this range were flagged as having unacceptable recoveries. Matrix spikes were performed for VOCs, low-level fumigants, pesticides and pesticide degradates, 1,2,3-TCP, and NDMA because the analytical methods for these constituents may be susceptible to matrix interferences.

\section{Matrix-Spike Recoveries}

Table A5A-D presents a summary of matrix-spike recoveries for the WSJV study unit. Spiked samples were collected at up to 16 percent of the wells sampled.

Six groundwater samples were spiked with VOCs to calculate matrix-spike recoveries. Median matrix-spike recoveries for all 85 spike compounds were between 70 and 130 percent. Two spike compounds (hexachlorobutadiene and styrene) had at least one matrix-spike recovery $<70$ percent. Two spike compounds (acetone and DBCP) had at least one matrix-spike recovery $>130$ percent, and DCBP was detected in groundwater samples (table A5A).

Eight groundwater samples were spiked with low-level fumigants to calculate matrix-spike recoveries. Median matrix-spike recoveries for both spike compounds were 
between 70 and 130 percent. DBCP had at least one matrixspike recovery $>130$ percent and two recoveries $<70$ percent. EDB had three matrix-spike recoveries $<70$ percent.

Eight groundwater samples were spiked with pesticide and pesticide degradate compounds to calculate matrixspike recoveries. Median matrix-spike recoveries for 61 of the 83 spike compounds were between 70 and 130 percent. Twenty of the spike compounds had median matrix-spike recoveries $<70$ percent, and two had median matrix-spike recoveries $>130$ percent. Of the 16 compounds detected in groundwater samples, 14 had median matrix-spike recoveries within the acceptable range (table A5C).

The median matrix-spike recovery for hexazinone was less than the acceptable range (64.7 percent). Hexazinone was detected in three DM study area grid wells $(0.029 \mu \mathrm{g} / \mathrm{L}$, $0.009 \mu \mathrm{g} / \mathrm{L}$, and $0.045 \mu \mathrm{g} / \mathrm{L}$ ) and four DM-U wells $(0.012 \mu \mathrm{g} / \mathrm{L}, 0.027 \mu \mathrm{g} / \mathrm{L}, 0.024 \mu \mathrm{g} / \mathrm{L}$, and $0.076 \mu \mathrm{g} / \mathrm{L}$; table 6$)$. The minimum detected concentration (E0.009 $\mu \mathrm{g} / \mathrm{L})$ is slightly greater than the LRL of $0.008 \mu \mathrm{g} / \mathrm{L}$. Because hexazinone was detected at a concentration of $0.001 \mu \mathrm{g} / \mathrm{L}$, greater than the LRL, it was determined that the less than acceptable median matrix-spike recovery did not affect the NWQL analysis and results.

The median matrix-spike recovery for tebuthiuron was greater than the acceptable range (138.3 percent). Tebuthiuron was detected in one understanding well (DM-U-01) at a concentration of E0.01 $\mu \mathrm{g} / \mathrm{L}$ (table 6). Because tebuthiuron was detected at a concentration an order of magnitude less than the LRL of $0.028 \mu \mathrm{g} / \mathrm{L}$ (table 6), it was determined that the less than acceptable median matrix-spike recovery did not affect the NWQL analysis and results.

At least one matrix-spike recovery for 44 pesticide and pesticide degradate spike compounds was $<70$ percent. Of these spike compounds, deethylatrazine, 2-ethyl-6methylaniline, and hexazinone were detected in groundwater samples. One pesticide and pesticide degradate spike compound (fipronil sulfide) had at least one matrix-spike recovery $<70$ percent and one matrix-spike recovery $>130$ percent, but it was not detected in groundwater samples. At least one matrix-spike recovery for seven pesticide and pesticide degradate spike compounds was $>130$ percent. Of these spike compounds, tebuthiuron was detected in groundwater samples.

Four groundwater samples were spiked with NDMA, and nine groundwater samples were spiked with 1,2,3-TCP to calculate matrix-spike recoveries at Weck. All median matrixspike recoveries were between 70 and 130 percent.

\section{Surrogate Compounds}

Surrogate compounds are added to groundwater samples in the laboratory prior to analysis to evaluate the recovery of similar constituents. Surrogate compounds were added in the laboratory to all groundwater and QC samples that were analyzed by the NWQL for VOCs and pesticides and pesticide degradates. Surrogates are used to identify general problems that may arise during laboratory sample analysis that could affect the analysis results for all compounds in that sample. Potential problems include matrix interferences (such as high levels of DOC) that produce a positive bias or incomplete laboratory recovery (possibly because of improper maintenance and calibration of analytical equipment) that produces a negative bias. A 70 to 130 percent recovery of surrogates, in general, is considered acceptable; values outside of this range indicate possible problems with the processing and analysis of samples (Connor and others, 1998; Sandstrom and others, 2001).

\section{Surrogate Compound Recoveries}

Table A6 presents a summary of the surrogate recoveries for the WSJV study unit. The table lists the surrogate, the analytical schedule on which it was applied, the number of analyses for blank and groundwater samples, the number of surrogate recoveries $<70$ percent, and the number of surrogate recoveries $>130$ percent for the blank and groundwater samples. Blank and groundwater samples were considered separately to assess whether or not the matrixes present in groundwater samples affect surrogate recoveries.

Most surrogate recoveries for the blank and groundwater samples were within the acceptable range of 70 to 130 percent. In total, 92 percent of the blank and 93 percent of the groundwater sample surrogate recoveries for VOC analyses were within the acceptable range. In addition, 92 percent of the blank and 94 percent of the groundwater sample surrogate recoveries for pesticide and pesticide degradate analyses were within the acceptable range. There were no significant differences between VOC and pesticide and pesticide degradate surrogate recoveries in blank and groundwater samples (Wilcoxon rank sum test, $\mathrm{p}<0.05$ ). 


\section{Laboratory Quality-Control Results for Inorganic Constituents}

Laboratory bias as indicated from internal laboratory QC tests was investigated to determine whether or not the WSJV study unit data were affected by laboratory procedures. The BQS operates the Inorganic Blind Sample Project (IBSP) to monitor and evaluate the quality of results for analyses of trace elements, nutrients, major and minor ions, silica, and TDS by the NWQL. The IBSP submits standard reference samples consisting of natural matrix water samples spiked with reagent chemicals that contain known concentrations of the inorganic constituents (Farrar and Long, 1997). The IBSP data are readily available on the BQS website, and the BQS issues monthly summaries of the results, reporting the amount of bias observed in the results (http://bqs.usgs.gov/IBSP/).

The BQS monthly summaries were examined for March through July 2010, the period of time during which samples were analyzed for the WSJV study unit. During this time period, the BQS reported that four inorganic constituents showed evidence of bias: a positive bias for barium, cadmium, and molybdenum and a negative bias for magnesium.

Examination of the results for the IBSP samples for these four constituents indicated that the analytical biases reported by the BQS were not significant.

The IBSP samples for barium had concentrations ranging from $26.0 \mu \mathrm{g} / \mathrm{L}$ to $63.0 \mu \mathrm{g} / \mathrm{L}$. The average difference between the measured and expected concentrations was $1.0 \mu \mathrm{g} / \mathrm{L}$ (standard deviation $=2.0 \mu \mathrm{g} / \mathrm{L}$ ), and the average relative percent difference between the measured and expected concentrations was 3 percent (standard deviation $=4$ percent). The MCL-CA for barium is $1,000 \mu \mathrm{g} / \mathrm{L}$; thus, the estimate of bias from the ISBP samples would be relevant for assessment of whether groundwater samples have barium concentrations greater than or less than the MCL-CA concentration or greater than or less than one-half of the MCL-CA concentration. However, the maximum concentration of barium in samples from the WSJV study unit was $346 \mu \mathrm{g} / \mathrm{L}$ (table 8); thus, a potential positive bias of $1.0 \mu \mathrm{g} / \mathrm{L}$, or 3 percent, would not result in a measured concentration greater than either threshold when the true concentration would have been below the threshold.

The IBSP samples for cadmium had concentrations ranging from $0.18 \mu \mathrm{g} / \mathrm{L}$ to $1.7 \mu \mathrm{g} / \mathrm{L}$. The average difference between the measured and expected concentrations was
$0.12 \mu \mathrm{g} / \mathrm{L}$ ( standard deviation $=0.08 \mu \mathrm{g} / \mathrm{L}$ ), and the average relative percent difference between the measured and expected concentrations was 24 percent (standard deviation $=38$ percent). The MCL-US for cadmium is $5 \mu \mathrm{g} / \mathrm{L}$, thus the estimate of bias from the ISBP samples would be relevant for assessment of whether groundwater samples have cadmium concentrations greater than or less than the MCL-US concentration or greater than or less than one-half of the MCL-US concentration. However, the maximum concentration of cadmium in samples from the WSJV study unit was $0.34 \mu \mathrm{g} / \mathrm{L}$ (table 8); thus, a potential positive bias of $0.12 \mu \mathrm{g} / \mathrm{L}$, or 24 percent, would not result in a measured concentration above either threshold when the true concentration would have been below the threshold.

The IBSP samples for molybdenum had concentrations ranging from $1.8 \mu \mathrm{g} / \mathrm{L}$ to $33.4 \mu \mathrm{g} / \mathrm{L}$. The average difference between the measured and expected concentrations was $0.50 \mu \mathrm{g} / \mathrm{L}$ (standard deviation $=0.79 \mu \mathrm{g} / \mathrm{L}$ ), and the average relative percent difference between the measured and expected concentrations was 5 percent (standard deviation $=4$ percent). The HAL-US for molybdenum is $40 \mu \mathrm{g} / \mathrm{L}$, thus the estimate of bias from the ISBP samples would be relevant for assessment of whether groundwater samples have molybdenum concentrations greater than or less than the HAL-US concentration or greater than or less than one-half of the HAL-US concentration. Taking into account the potential positive bias of $0.5 \mu \mathrm{g} / \mathrm{L}$ or 5 percent for molybdenum concentrations reported by the NWQL, there would have been no significant change in whether the reported values were greater than or less than the HAL-US concentration or greater than or less than one-half of the HAL-US concentration. The IBSP samples for magnesium had concentrations ranging from $0.05 \mathrm{mg} / \mathrm{L}$ to $7.3 \mathrm{mg} / \mathrm{L}$. The average difference between the measured and expected concentrations was $-0.17 \mathrm{mg} / \mathrm{L}$ (standard deviation $=0.22 \mathrm{mg} / \mathrm{L}$ ), and the average relative percent difference between the measured and expected concentrations was -5 percent (standard deviation $=4$ percent). A negative bias of 5 percent or $0.17 \mathrm{mg} / \mathrm{L}$ can only potentially affect measured concentrations of less than $7.3 \mathrm{mg} / \mathrm{L}$ in WSJV study unit groundwater samples (table 10). Magnesium does not currently have an established regulatory/ non-regulatory health-based or aesthetic benchmark; therefore, this negative bias will not affect the assessments of groundwater quality being made by the GAMA-PBP. 


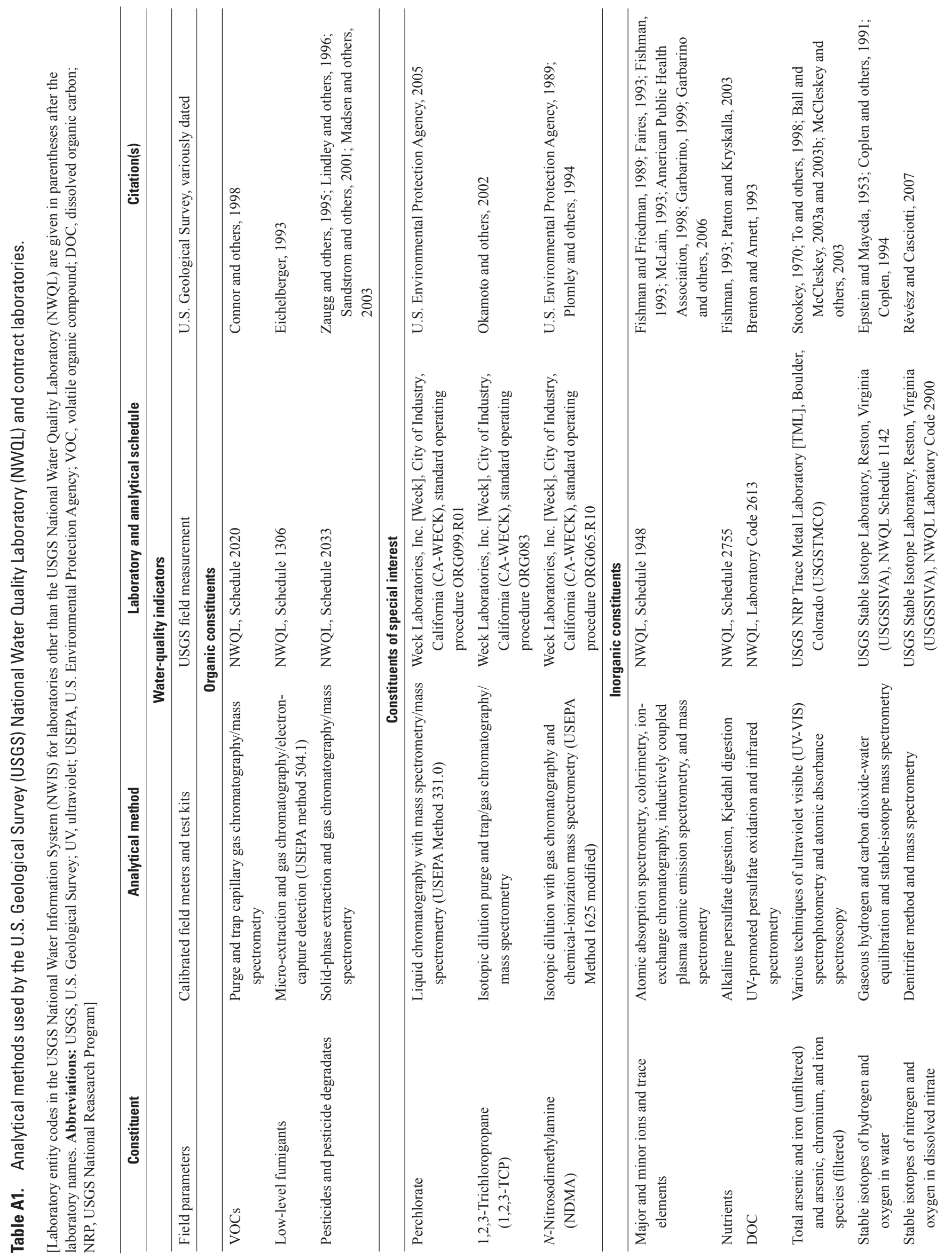




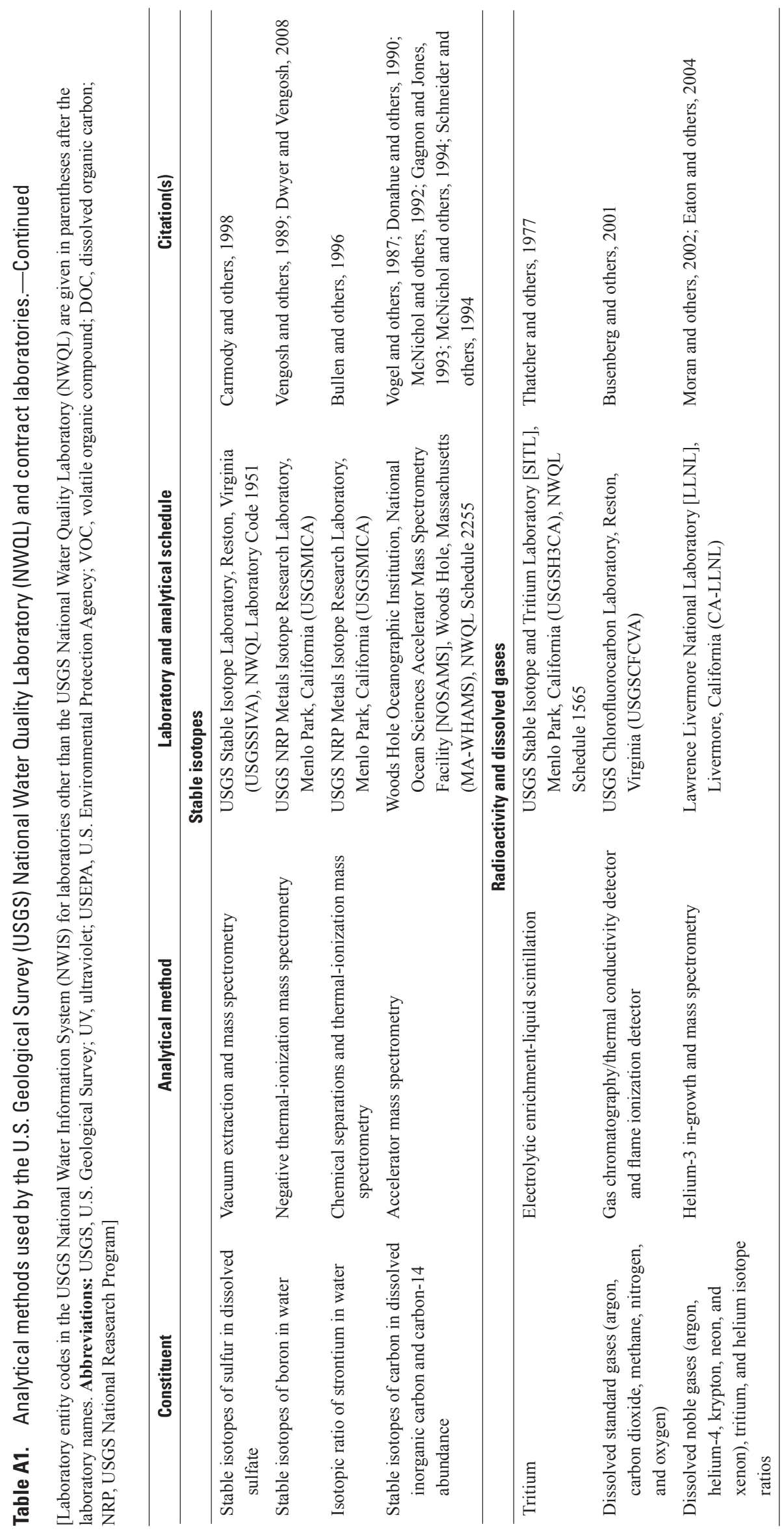




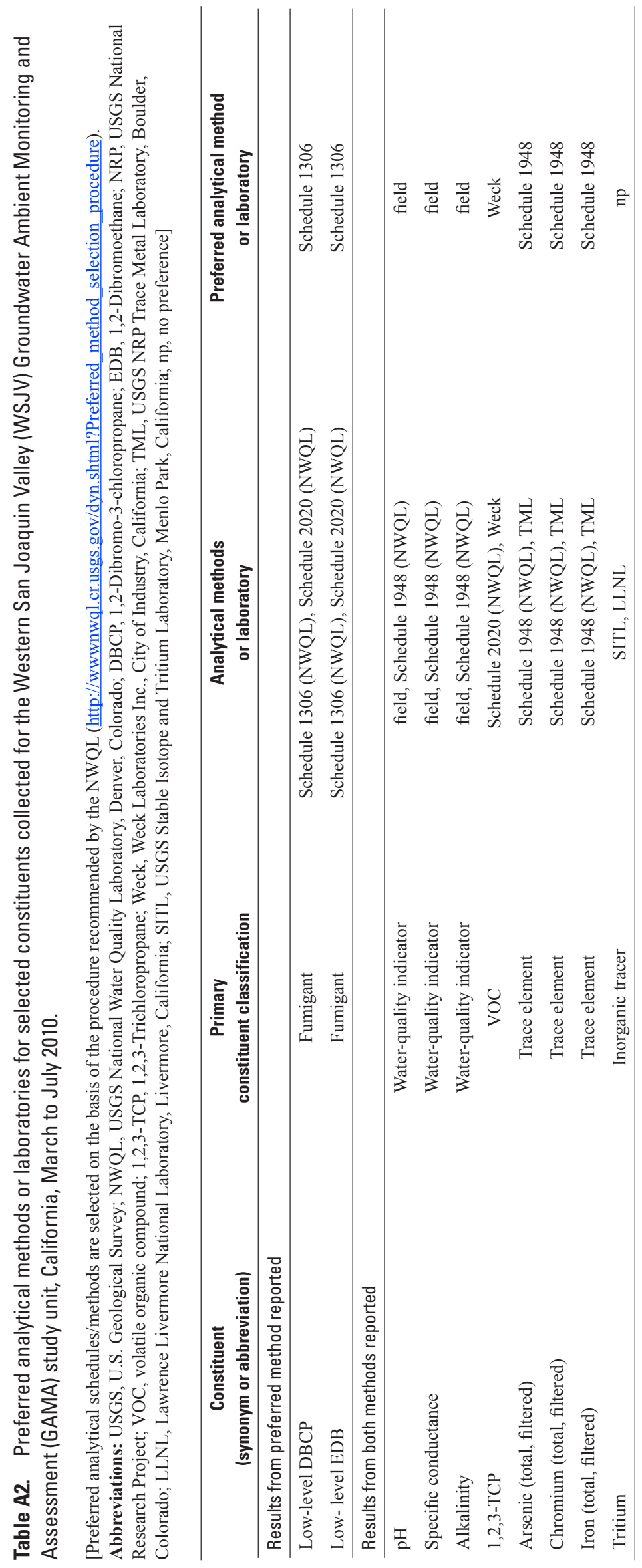


Table A3. Constituents detected in blanks and the study reporting level (SRL) analysis for the Western San Joaquin Valley (WSJV) Groundwater Ambient Monitoring and Assessment (GAMA) study unit, California, March to July 2010.

[The SRLs were defined by: (1) the highest concentration in blanks collected for this study unit, (2) Fram and others (2012), or (3) Olsen and others (2010). Abbreviations: LRL, laboratory reporting level; volatile organic compound, VOC; $\leq$, less than or equal to; E, estimated or having a higher degree of uncertainty; $\mu \mathrm{g} / \mathrm{L}$, micrograms per liter; mg/L, milligrams per liter; nv, no value in category; —, not detected; TDS, total dissolved solids]

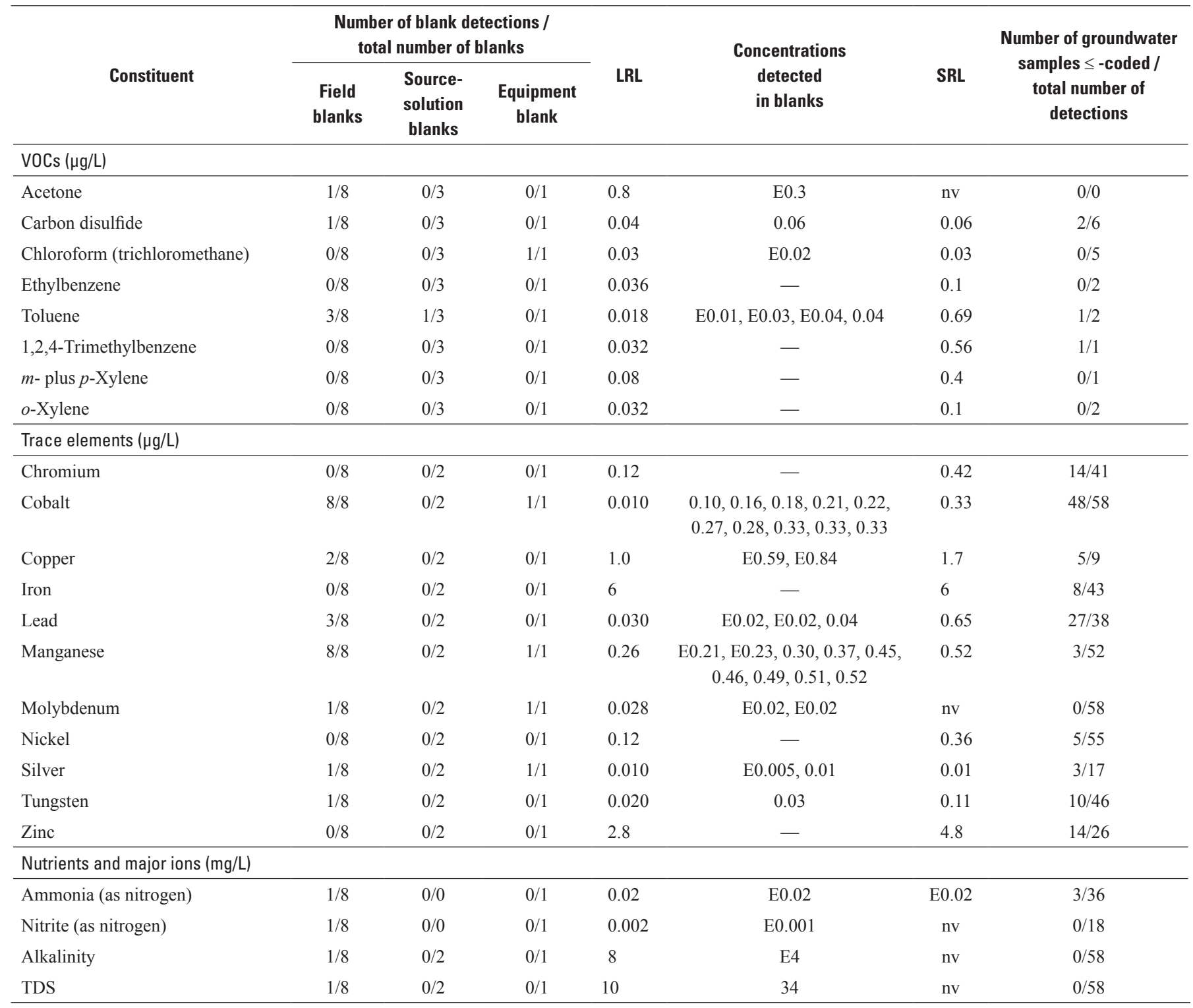




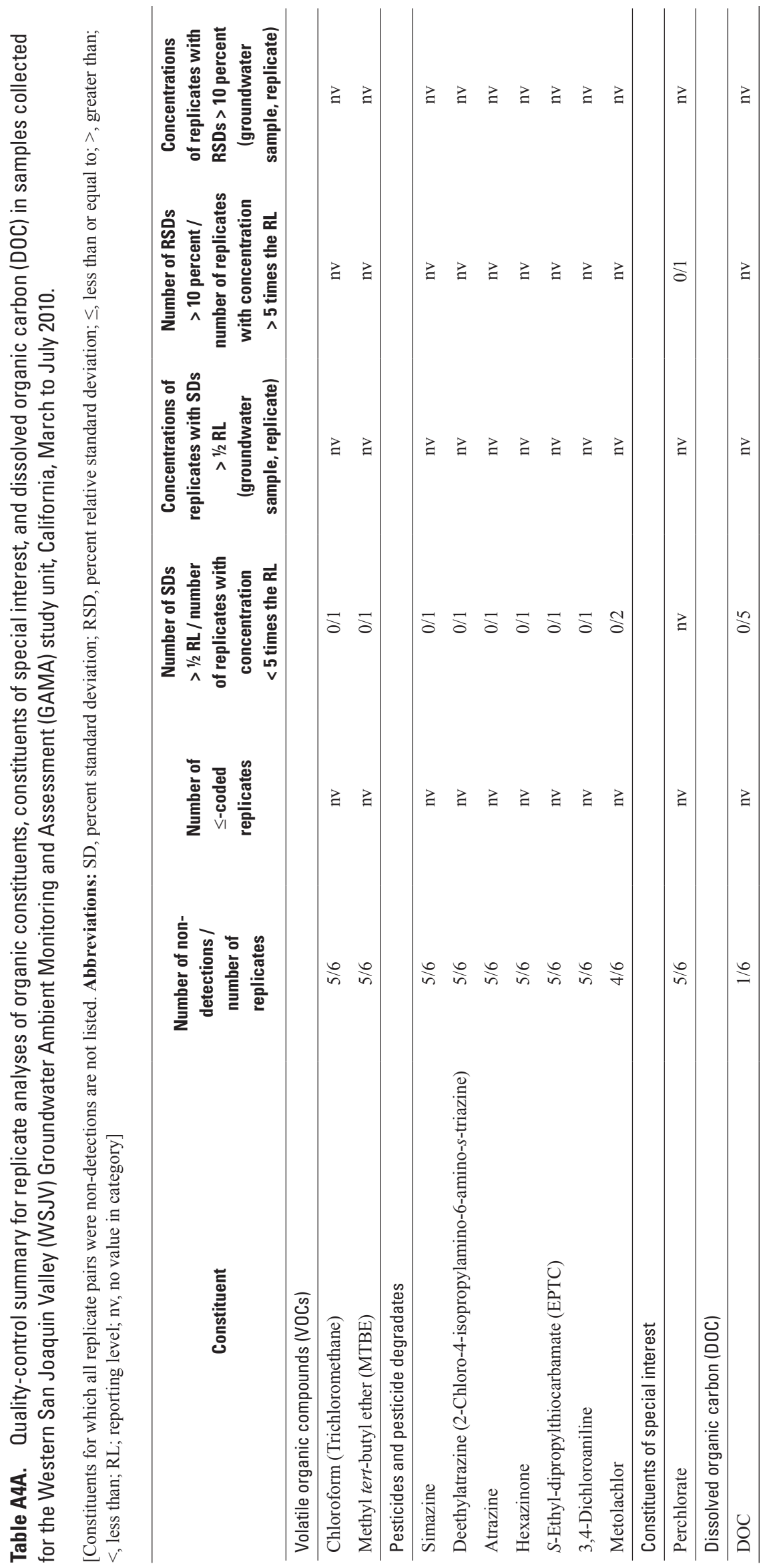


Table A4B. Quality-control summary for replicate analyses of inorganic constituents in samples collected for the Western San Joaquin Valley (WSJV) Groundwater Ambient Monitoring and Assessment (GAMA) study unit, California, March to July 2010.

[Constituents for which all replicate pairs were non-detections are not listed. Abbreviations: SD, percent standard deviation; RSD, percent relative standard deviation in percent; RL, reporting level; >, greater than; <, less than; $\leq$, less than or equal to; nv, no value in category]

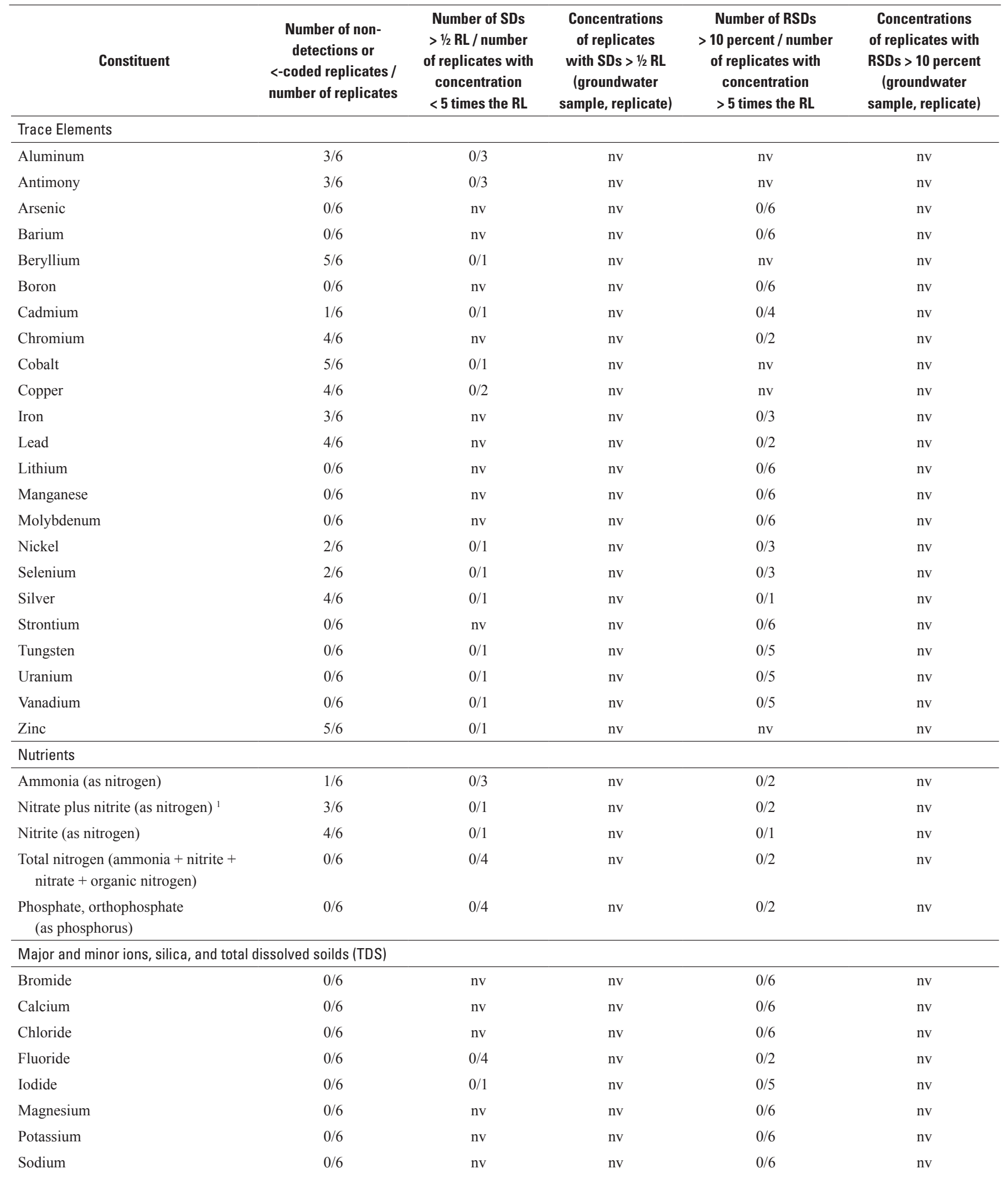


Table A4B. Quality-control summary for replicate analyses of inorganic constituents in samples collected for the Western San Joaquin Valley (WSJV) Groundwater Ambient Monitoring and Assessment (GAMA) study unit, California, March to July 2010.—Continued

[Constituents for which all replicate pairs were non-detections are not listed. Abbreviations: SD, percent standard deviation; RSD, percent relative standard deviation in percent; RL, reporting level; >, greater than; $<$, less than; $\leq$, less than or equal to; nv, no value in category]

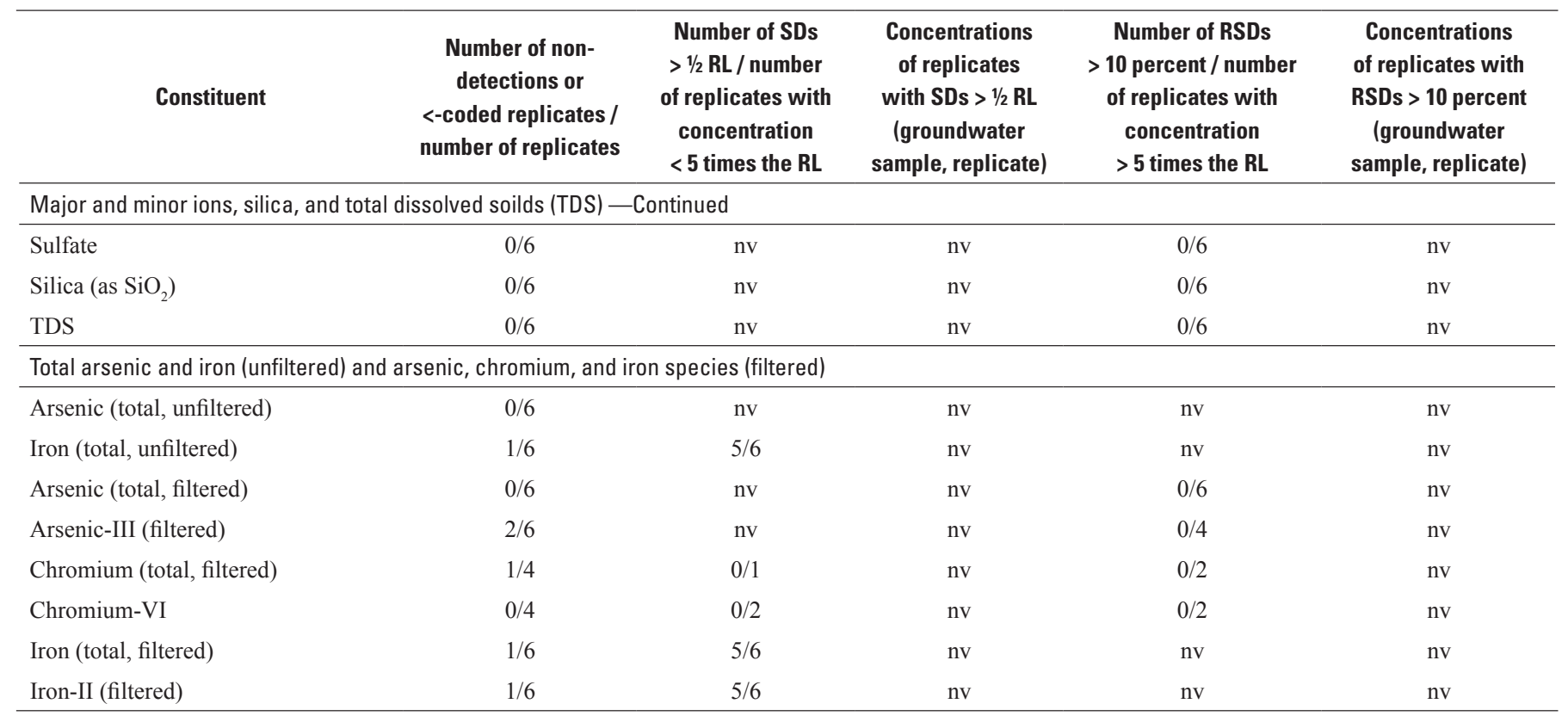

${ }^{1}$ Nitrite plus nitrate (as nitrogen) is referred to as nitrate in the text for clarity. 
Table A5A. Quality-control summary for matrix-spike recoveries of volatile organic compounds (VOCs) in samples collected for the Western San Joaquin Valley (WSJV) Groundwater Ambient Monitoring and Assessment (GAMA) study unit, California, March to July 2010.

[Acceptable recovery range is between 70 and 130 percent]

\begin{tabular}{|c|c|c|c|c|}
\hline Constituent & $\begin{array}{c}\text { Number of spike } \\
\text { samples }\end{array}$ & $\begin{array}{c}\text { Minimum recovery } \\
\text { (percent) }\end{array}$ & $\begin{array}{c}\text { Maximum recovery } \\
\text { (percent) }\end{array}$ & $\begin{array}{l}\text { Median recovery } \\
\text { (percent) }\end{array}$ \\
\hline Acetone & 6 & 101 & 150 & 123.4 \\
\hline tert-Amyl methyl ether (TAME) & 6 & 90 & 103 & 94.7 \\
\hline Benzene $^{1}$ & 6 & 96 & 111 & 100.9 \\
\hline Bromobenzene & 6 & 90 & 103 & 94.6 \\
\hline Bromodichloromethane & 6 & 94 & 108 & 104.3 \\
\hline Bromoform (Tribromomethane) ${ }^{1}$ & 6 & 84 & 109 & 99.4 \\
\hline Bromomethane (Methyl bromide) & 6 & 92 & 118 & 106.4 \\
\hline$n$-Butylbenzene & 6 & 79 & 106 & 90.1 \\
\hline sec-Butylbenzene & 6 & 85 & 109 & 93.7 \\
\hline Chlorobenzene & 6 & 92 & 102 & 95.5 \\
\hline Chloroethane & 6 & 101 & 112 & 103.3 \\
\hline Chloroform (Trichloromethane) ${ }^{1}$ & 6 & 101 & 116 & 112.9 \\
\hline Chloromethane & 6 & 103 & 116 & 105.7 \\
\hline 3-Chloropropene & 6 & 107 & 121 & 110.2 \\
\hline 2-Chlorotoluene & 6 & 90 & 114 & 95.8 \\
\hline 4-Chlorotoluene & 6 & 87 & 114 & 97.1 \\
\hline Dibromochloromethane $^{1}$ & 6 & 88 & 110 & 102.5 \\
\hline 1,2-Dibromo-3-chloropropane (DBCP) ${ }^{1}$ & 6 & 94 & 132 & 105.2 \\
\hline Dichlorodifluoromethane (CFC-12) & 6 & 70 & 99 & 87.6 \\
\hline 1,1-Dichloroethane $(1,1-D C A)^{1}$ & 6 & 100 & 116 & 105.2 \\
\hline 1,2-Dichloroethane (1,2-DCA) & 6 & 101 & 117 & 109.0 \\
\hline 1,1-Dichloroethene (1,1-DCE) & 6 & 91 & 104 & 97.3 \\
\hline cis-1,2-Dichloroethene (cis-1,2-DCE) & 6 & 97 & 109 & 101.8 \\
\hline trans-1,2-Dichloroethene (trans-1,2-DCE) & 6 & 97 & 116 & 101.1 \\
\hline 1,2-Dichloropropane ${ }^{1}$ & 6 & 95 & 104 & 98.9 \\
\hline 1,3-Dichloropropane & 6 & 97 & 110 & 103.6 \\
\hline 2,2-Dichloropropane & 6 & 89 & 97 & 92.0 \\
\hline 1,1-Dichloropropene & 6 & 89 & 100 & 92.5 \\
\hline cis-1,3-Dichloropropene & 6 & 82 & 97 & 88.4 \\
\hline trans-1,3-Dichloropropene & 6 & 82 & 95 & 89.6 \\
\hline Diethyl ether & 6 & 104 & 121 & 105.9 \\
\hline Diisopropyl ether (DIPE) & 6 & 91 & 113 & 96.3 \\
\hline
\end{tabular}


Table A5A. Quality-control summary for matrix-spike recoveries of volatile organic compounds (VOCs) in samples collected for the Western San Joaquin Valley (WSJV) Groundwater Ambient Monitoring and Assessment (GAMA) study unit, California, March to July 2010.-Continued

[Acceptable recovery range is between 70 and 130 percent]

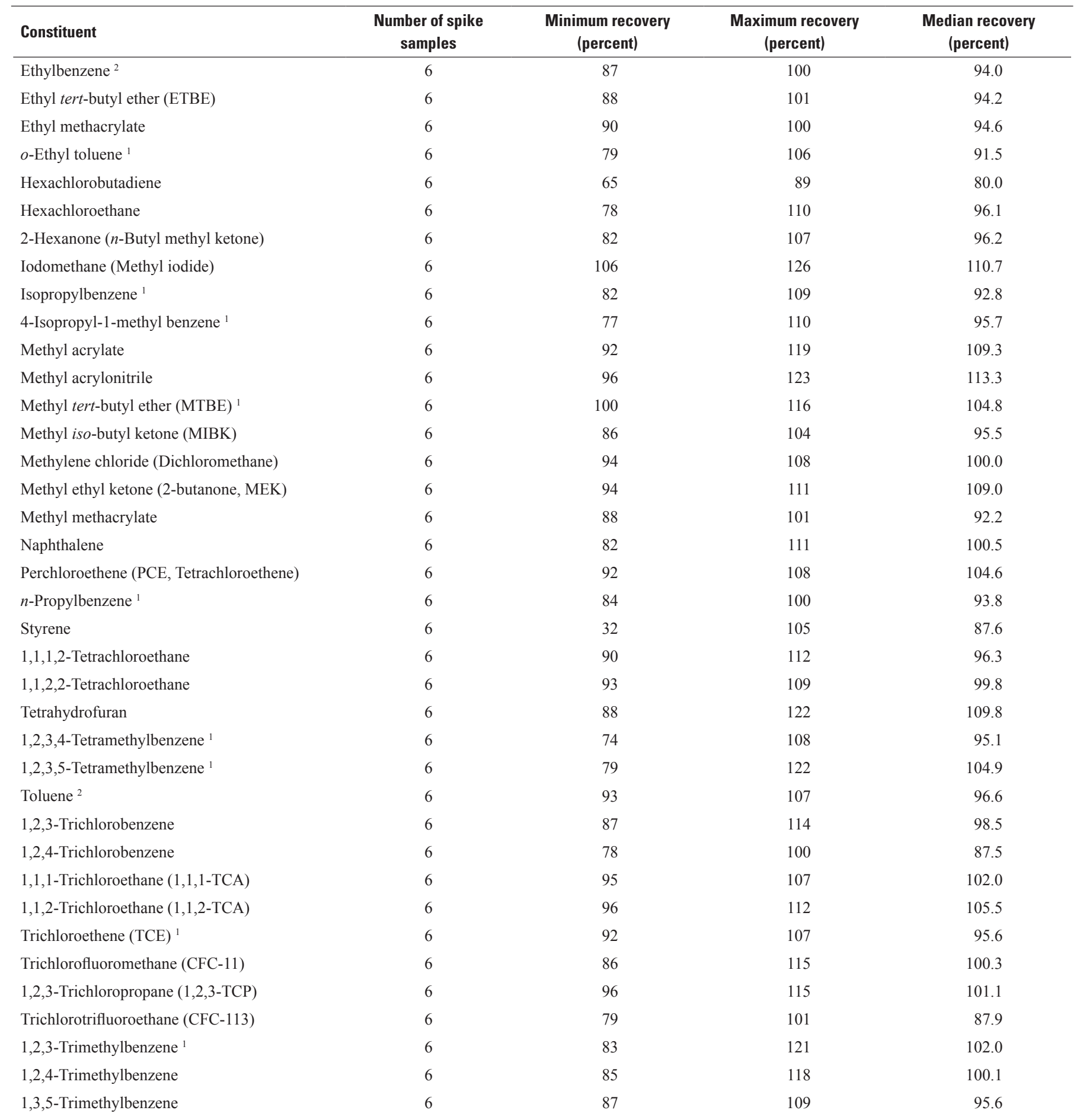


Table A5A. Quality-control summary for matrix-spike recoveries of volatile organic compounds (VOCs) in samples collected for the Western San Joaquin Valley (WSJV) Groundwater Ambient Monitoring and Assessment (GAMA) study unit, California, March to July 2010.-Continued

[Acceptable recovery range is between 70 and 130 percent]

\begin{tabular}{lcccc}
\hline Constituent & $\begin{array}{c}\text { Number of spike } \\
\text { samples }\end{array}$ & $\begin{array}{c}\text { Minimum recovery } \\
\text { (percent) }\end{array}$ & $\begin{array}{c}\text { Maximum recovery } \\
\text { (percent) }\end{array}$ & $\begin{array}{c}\text { Median recovery } \\
\text { (percent) }\end{array}$ \\
\hline Vinyl bromide (Bromoethene) & 6 & 99 & 110 & 101.2 \\
Vinyl chloride (Chloroethene) & 6 & 104 & 125 & 113.2 \\
$m$ - plus $p$-Xylene ${ }^{2}$ & 6 & 86 & 111 & 96.8 \\
$o$-Xylene ${ }^{2}$ & 6 & 86 & 101 & 91.9 \\
\hline
\end{tabular}

${ }^{1}$ Constituent detected in groundwater samples.

${ }^{2}$ The SRLs were defined by Fram and others (2012). Values measured at concentrations less than or equal to the SRL have been flagged with a $\leq$ symbol, reclassified as non-detections, and not included in the calculations of detection frequencies (with the exception of wells WS-U-01 and WS-U-02 [see the appendix section titled "Detections in Blanks and Application of SRLs" for details]).

Table A5B. Quality-control summary for matrix-spike recoveries of low-level fumigants in samples collected for the Western San Joaquin Valley (WSJV) Groundwater Ambient Monitoring and Assessment (GAMA) study unit, California, March to July 2010.

[Acceptable recovery range is between 70 and 130 percent]

\begin{tabular}{lcccc}
\hline Constituent & $\begin{array}{c}\text { Number of spike } \\
\text { samples }\end{array}$ & $\begin{array}{c}\text { Minimum recovery } \\
\text { (percent) }\end{array}$ & $\begin{array}{c}\text { Maximum recovery } \\
\text { (percent) }\end{array}$ & $\begin{array}{c}\text { Median recovery } \\
\text { (percent) }\end{array}$ \\
\hline 1,2-Dibromo-3-chloropropane (DBCP) ${ }^{1}$ & 8 & 42 & 115 & 95.7 \\
1,2-Dibromoethane (EDB) & 8 & 48 & 112 & 84.4 \\
\hline
\end{tabular}

\footnotetext{
${ }^{1}$ Constituent detected in groundwater samples.
} 
Table A5C. Quality-control summary for matrix-spike recoveries of pesticides and pesticide degradates in samples collected for the Western San Joaquin Valley (WSJV) Groundwater Ambient Monitoring and Assessment (GAMA) study unit, California, March to July 2010.

[Acceptable recovery range is between 70 and 130 percent]

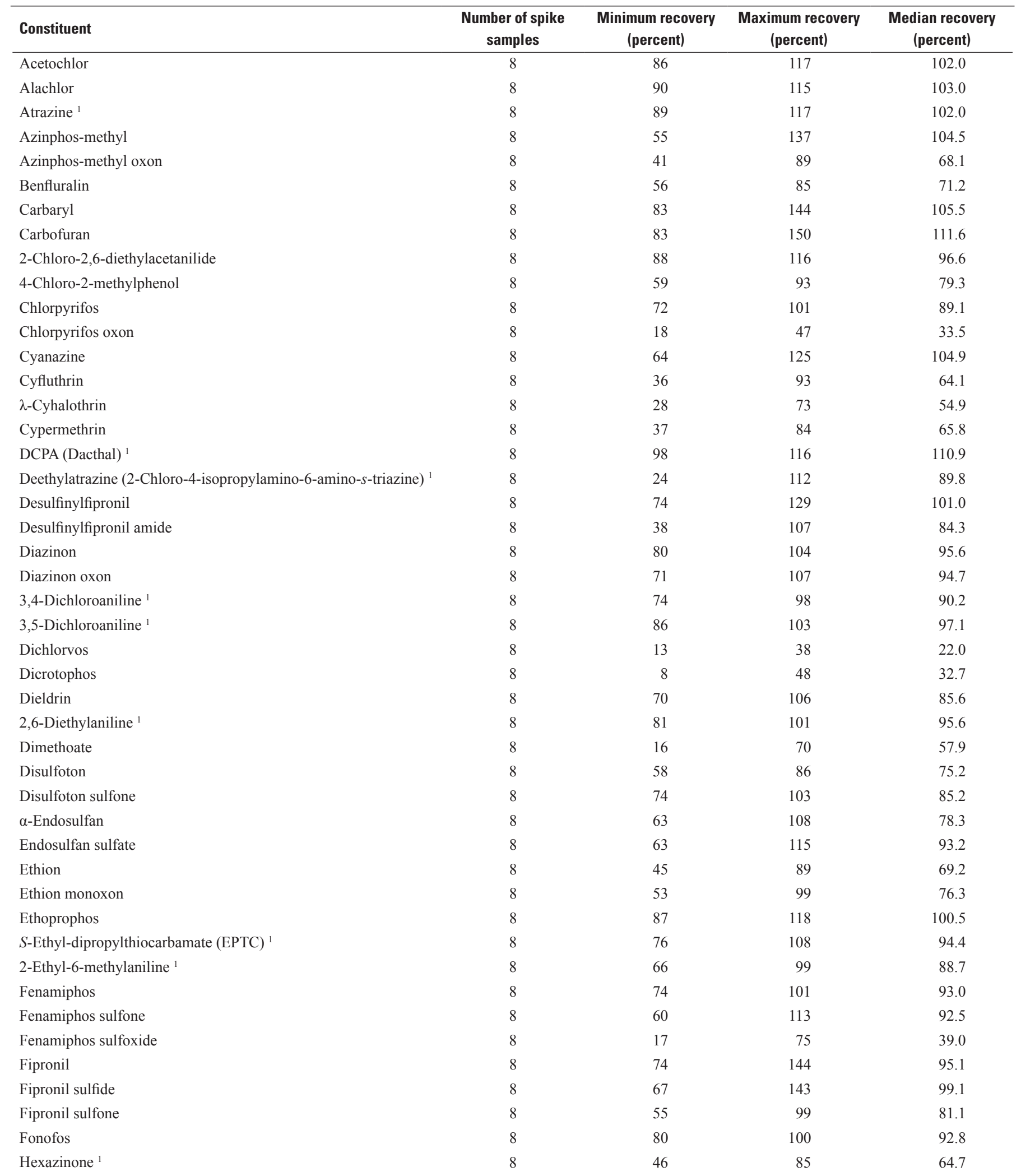


Table A5C. Quality-control summary for matrix-spike recoveries of pesticides and pesticide degradates in samples collected for the Western San Joaquin Valley (WSJV) Groundwater Ambient Monitoring and Assessment (GAMA) study unit, California, March to July 2010.-Continued

[Acceptable recovery range is between 70 and 130 percent]

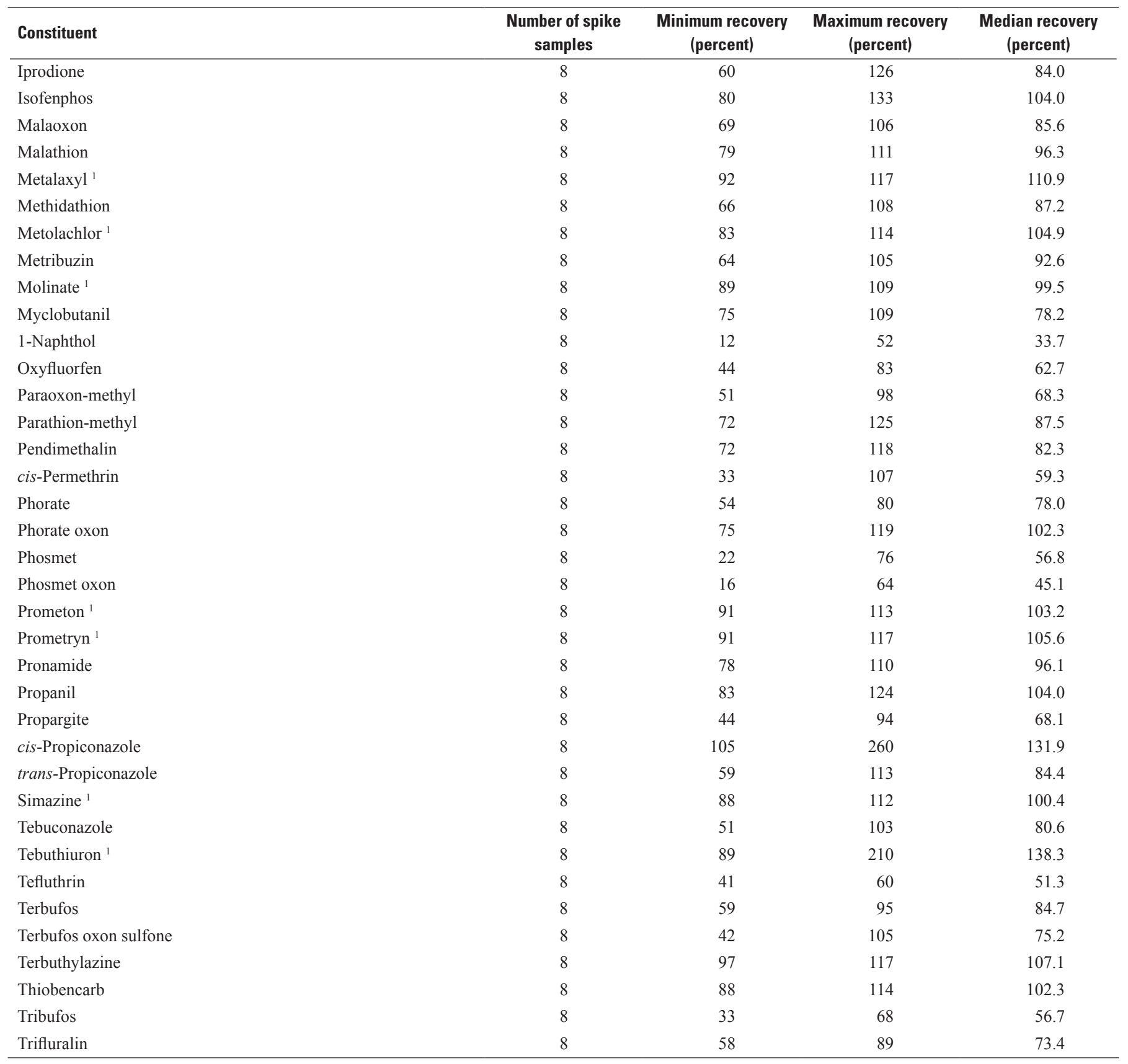

${ }^{1}$ Constituent detected in groundwater samples. 
Table A5D. Quality-control summary for matrix-spike recoveries of constituents of special interest in samples collected for the Western San Joaquin Valley (WSJV) Groundwater Ambient Monitoring and Assessment (GAMA) study unit, California, March to July 2010.

[Acceptable recovery range is between 70 and 130 percent]

\begin{tabular}{lcccc}
\hline Constituent & $\begin{array}{c}\text { Number of spike } \\
\text { samples }\end{array}$ & $\begin{array}{c}\text { Minimum recovery } \\
\text { (percent) }\end{array}$ & $\begin{array}{c}\text { Maximum recovery } \\
\text { (percent) }\end{array}$ & $\begin{array}{c}\text { Median recovery } \\
\text { (percent) }\end{array}$ \\
\hline $1,2,3$-Trichloropropane (1,2,3-TCP) ${ }^{1}$ & 9 & 95 & 117 & 110 \\
$N$-Nitrosodimethylamine (NDMA) & 4 & 86 & 131 & 113.0 \\
\hline
\end{tabular}

${ }^{1}$ Constituent detected in groundwater samples. 


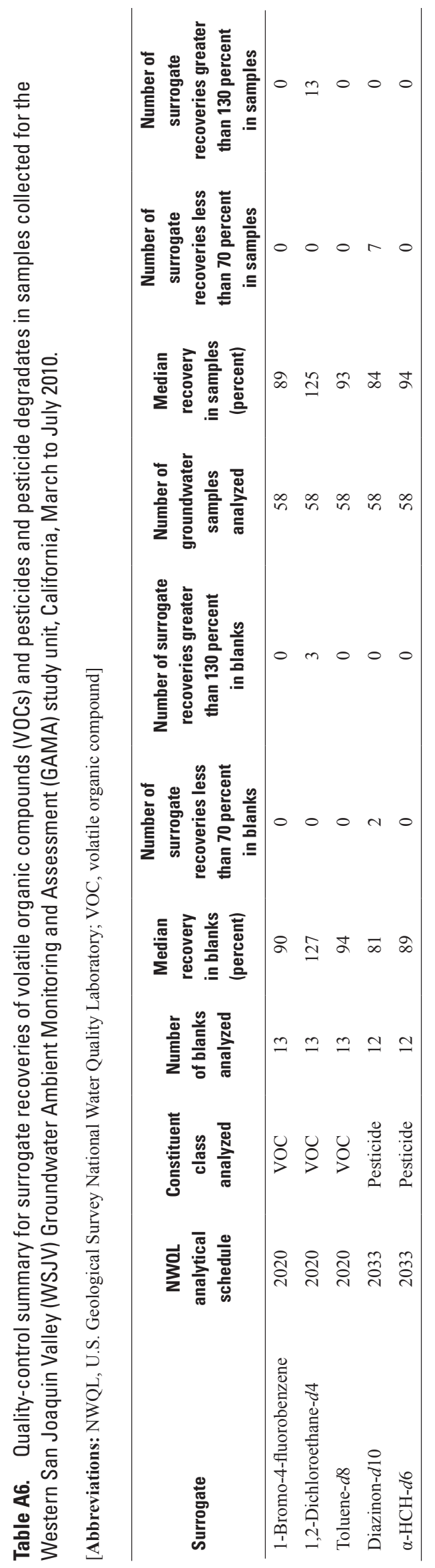


102 Groundwater-Quality Data in the Western San Joaquin Valley Study Unit, 2010 
Publishing support provided by the U.S. Geological Survey Science

Publishing Network, Sacramento, Tacoma, and Raleigh Publishing Service Centers

For more information concerning the research in this report, contact the

Director, California Water Science Center U.S. Geological Survey

6000 J Street, Placer Hall

Sacramento, California 95819

http://ca.water.usgs.gov 
